\title{
Alaska Native
}

\section{Wx Training}

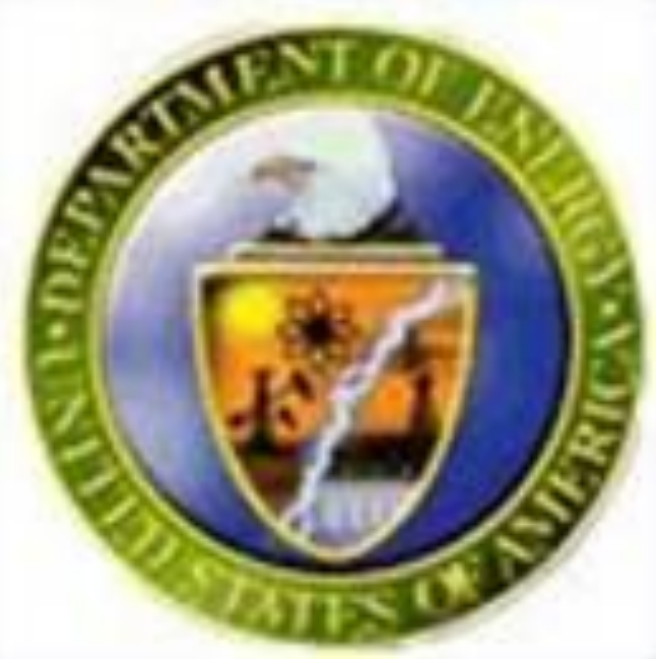

\section{U.S. Department of Energy Golden Field Office}

First Steps Toward Tribal Weatherization Human Capacity Development

Grantee:

Project Title:

Funds Requested:

Award Number:

Grant Period:

Project Title:
Tlingit-Haida Regional Housing Authority

Alaska Native Weatherization Training and Jobs Project $\$ 199,942$

DE-EE0002526

Start May 28, 2010 End March 31, 2013

Alaska Native Weatherization Training and Jobs Program

Project Location: Juneau, Ketchikan, and Southeast Alaska Communities 


\section{Title: $\quad$ First Steps Toward Tribal Weatherization - Human Capacity Development}

Key Participants:

Tlingit Haida Regional Housing Authority U.S HUD designated TDHE

Craig Moore

Develop \& Construction Management

P.O. Box 32237

Juneau, Alaska 99803

Phone: 907-780-3130

Fax: 907-780-6895

Email: cmoore@thrha.org

Joanne Wiita

P.O. Box 32237

Juneau, Alaska 99803

Phone: 907-780-3158

Fax: 907-780-6895

Email:jwiita@thrha.org
University of Alaska, Southeast Career Education Department Marquam George, Associate Professor Construction and Technology 11120 Glacier Highway Juneau, Alaska 99801 Phone: 907-796-6124 Fax: 907-796-6571 Email: marquam.george@uas.alaska.edu

\section{List of Acronyms}

ACDC - Alaska Community Development Corporation AHFC - Alaska Housing Finance Corporation CBJ - City and Borough of Juneau CCTHITA - Central Council Tlingit and Haida Tribes of Alaska DOE - United States Department of Energy THRHA - Tlingit Haida Regional Housing Authority UAS - University of Alaska Southeast 
Table of Contents

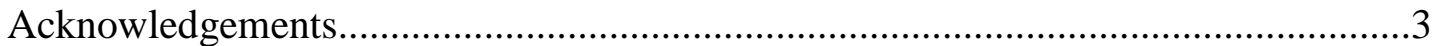

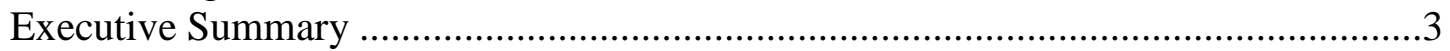

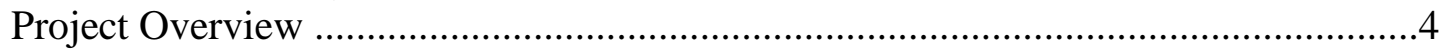

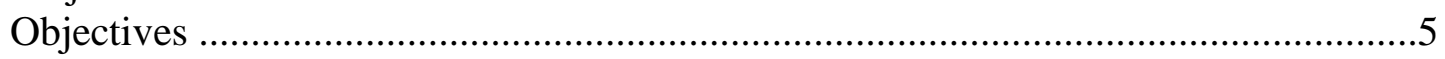

Description of Activities Performed ……………………....................................6

Conclusions and Recommendations ....................................................................

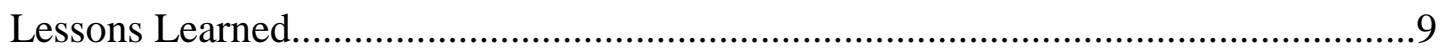

\section{Acknowledgements}

Tlingit Haida Regional Housing Authority acknowledges many individuals and organizations that assisted in establishing and supporting the Native Weatherization Training Program.

Central Council of Tlingit Haida Indian Tribes of Alaska (CCTHITA)

Percy Frisby, Energy Department

Corrine Garza, Controller

Amy Skilbred, Contractor

Mimi Burbage, Alaska Housing Finance Corporation

Marquam George, University of Alaska Southeast

Charlie Carlson, SERRC

First Bank

We especially thank Tribal Citizens, trainee participants, and also Tribal communities throughout southeast Alaska.

\section{Executive Summary}

Project Description: The Alaska Native Weatherization Training and Jobs Project expanded weatherization services for tribal members' homes in southeast Alaska while providing weatherization training and on the job training (OJT) for tribal citizens that lead to jobs and most probably careers in weatherization-related occupations.

The program resulted in; (a) 80 Alaska Native citizens provided with skills training in five weatherization training units that were delivered in cooperation with University of Alaska Southeast, in accordance with the U.S. Department of Energy Core Competencies for Weatherization Training that prepared participants for employment in three weatherizationrelated occupations: Installer, Crew Chief, and Auditor; (b) 25 paid OJT training opportunities for trainees who successfully completed the training course; and (c) employed trained personnel that have begun to rehab on over 1,000 housing units for weatherization. 
Area and Tribes: Most members of the Central Council Tlingit and Haida Indian Tribes of Alaska (CCTHITA), a federally recognized tribe, live in 24 communities scattered throughout southeast Alaska's 600-mile archipelago. These communities are not connected by road, residents rely on ferry, barge, and air service for personal transportation and delivery of goods . Some of the area communities endure utility costs $275 \%$ above the National average, the high cost of energy in these remote locations (electricity over 60 cents per kilowatt-hour and diesel fuel over $\$ 6$ per gallon) disproportionately and adversely affect tribal members. This project has served as the catalyst for locally skilled work force to work on local homes that have helped households reduce cost of utilities.

The Tribal DOE First Steps grant has definitely made a positive change in the lives of Tribal members. The Alaska Native Weatherization Training and Jobs Project has been a win-win: it provided energy saving improvements to members' homes while expanding needed employment opportunities in our communities. Providing much needed tribal weatherization services in members' homes created over 150 jobs, reduced energy costs by up to $30 \%$ after homes were weatherized, and has helped our rural economies, our families, and our culture, in the interim of our long-term goal of less expensive, clean and renewable energy prospects.

\section{Project Overview}

\section{Project Description: Major Participants}

Tlingit Haida Regional Housing Authority (THRHA) and the University of Alaska Southeast (UAS) had major roles in the Alaska Native Weatherization Training and Jobs Project.

The THRHA Weatherization Program has been training participants throughout southeast Alaska for five years. The Alaska Native Weatherization Training and Jobs Project expanded on THRHA's existing program, providing a needed increase in trained Alaska Native citizens. THRHA programs serve 18 communities throughout southeast Alaska. THRHA is one of three weatherization (Wx) service providers in southeast Alaska. The Native First Steps not only assisted THRHA to train locals but also support training for Alaska Native citizens to become employed by other Wx Service Providers; the Alaska Community Development Corporation (ACDC) and RuralCap. Tribal Citizens acquired skills that qualified them for employment in Southeast Alaska and throughout the State of Alaska.

THRHA and other Wx Service providers receive funds through the Alaska Housing Finance Corporation (AHFC) to weatherize housing stock stock throughout Alaska. The Native First Steps has helped to fill demand for home weatherization workers in southeast Alaska with Alaska Native Citizens by providing weatherization experts through quality training programs.

THRHA partnered with the University of Alaska Southeast (UAS) to provide the weatherization training instruction for project participants at its campuses in Juneau and Ketchikan. UAS instructor Marquam George, a recognized pioneer of weatherization in Southeast's cold, wet climate, delivered these trainings. THRHA and many other Wx Service providers hired trainees for crew upon completion of training. 


\section{Project Description: Methods Employed}

Implementation of the Alaska Native Weatherization Training and Jobs Project included:

1. Specific training courses for Installer, Crew Chief, and Auditor at THRHA's Alaska Building Science Training Center as well as training for Installers and Crew Chiefs at the Ketchikan UAS campus.

2. Program participants were recruited from rural areas of southeast Alaska through contacts with construction crews, local tribal entities, and job centers, and through advertising

3. Evaluations of applicants were conducted as pre-requisite qualifications for the program, including qualifying under the Basic Competency evaluation, and a demonstrated past work commitment.

4. Candidates were interviewed and if approved a training offer was presented with an executed written agreement between THRHA and each program participant, stating both parties' obligations and expectations

5. Trainings were conducted from fall 2009 through winter 2012. Transportation, housing, and stipends were provided for trainees.

6. Upon completion of hands-on and class room training OJT was offered and/or employment with THRHA for trainees that successfully completed their training.

\section{Project Impact: Benefits and Outcomes}

This project provided expanded tribal weatherization services for Southeast's tribal members. Through this project, THRHA addressed two critical needs in southeast Alaska: (1) training and providing skilled jobs for Alaska Natives living in smaller communities; and (2) completion of timely weatherization repairs and retrofits of THRHA units and homes in communities that suffered high energy costs. The project provided the added benefits of reducing the consumption of energy in rural Southeast Alaska and reducing greenhouse gas emissions.

THRHA estimates that this program directly benefited well over 50 individual Alaska Native citizens selected for the training programs and job opportunities. Home weatherization reduced monthly expenses for families living and working in southeast Alaska communities while increasing income, which has helped to stabilize local economies and support the retention and strengthening of Alaska Native culture in Southeast's towns and villages.

\section{Objectives}

Tlingit and Haida Regional Housing Authority (THRHA), a US Department of Urban and Housing Development, Tribally Designated Housing Entity and non-profit corporation provides housing, weatherization training and weatherization programs for CCTHITA members in 17 southeast communities with year-round populations: Angoon, Craig, Douglas, Klawock, Kake, Kasaan, Hydaburg, Juneau, Ketchikan, Petersburg, Saxman, Skagway, Wrangell, Haines, Hoonah, Klukwan and Yakutat.

This project met our need to expand weatherization services and create jobs for Tribal members in southeast Alaska. This project provided training and on the job training (OJT) to Alaska Natives in weatherization and resulted in 150 weatherization jobs and over 730 weatherized homes (not including Wx Service providers other than THRHA). Putting trained Alaska Natives 
to work weatherizing homes and buildings provided the additional benefits of reducing the consumption of costly energy, lowering household expenses, and reducing green house gas emissions.

THRHA provided five weatherization training units, in accordance with the U.S. Department of Energy (DOE) Core Competencies for Weatherization Training for 150 Alaska Natives and 25 paid OJT trainees that successfully completed training courses. The outcome of this effort increased the number of trained installers, crew chiefs and auditors to help meet the demand for trained personnel. The University of Alaska Southeast (UAS) provided weatherization training instruction in Juneau and Ketchikan. And, THRHA provided OJT in conjunction with existing THRHA weatherization work crews.

Upon successfully completing the training, THRHA employed Alaska Natives to work with THRHA crews to weatherize over 730 homes in communities throughout southeast. Tribal DOE funding for this training program also helped to established the Alaska Building Science Center located in Juneau, Alaska.

\section{Tribal Weatherization Program}

This tribal weatherization training project continues as a part of the THRHA Weatherization Program. THRHA has a weatherization plan to address housing authority homes and units, along with non housing authority units in some communities. THRHA works on non-Tribal member homes through a memorandum of agreement with AHFC. THRHA has found it cost effective to take care of weatherization concerns community by community over the course of several construction seasons. To meet rural community weatherization demands, weatherization firms have employed more trained workers through the Tribal DOE training program.

THRHA will pursue additional funding to assist and continue with weatherization training for Alaska Natives now that this grant period is concluded. In the long term, THRHA will move-out of the business of weatherizing as existing homes become weatherized and building codes require sufficient weatherization to meet the challenges of our cold, wet climate. As weatherization needs are met in southeast Alaska, trained workers will have proven portable skills and experience as result of this program.

\section{Description of Activities Performed}

THRHA worked with UAS to provide weatherization training for this project, UAS brought local expertise in weatherizing for southeast Alaska's cold wet climate. This program alleviated the excessive expense and need for training programs outside Alaska. Providing local training resulted in a higher success rate for training completion and employment. This program was needed to meet the demand for skilled technical workers in rural communities. Tribal DOE funding helped to increase the number of skilled weatherization workers to work on homes locally as result of State of Alaska Weatherization funding established in 2008 for weatherization to homes throughout Alaska. 


\section{Obtaining Skills and Competencies}

THRHA identified and provided industry specific technical training and skills for southeast Alaska for 80 crew members; installation crew, crew chief, and auditor training courses. Some trainees were recruited from THRHA's existing crews to expand opportunities through additional training to become crew chiefs and auditors. New workers were recruited and trained to build on their existing experience, ability, and previous training.

\section{Recruitment}

THRHA will recruited a trainee pool through outreach to each community by field representatives of THRHA, local CCTHITA contacts, and local advertising. Selection of trainees were based on passage of the Basic Competencies and a demonstrated work ethic. Applicants provided a general description of their work history and/or academic background for THRHA to use in selecting trainees. THRHA interviewed trainee candidates. Both THRHA and trainees/apprentices entered a commitment outlining the requirements and expectations of both parties. THRHA provided training first to workers from those communities where weatherization projects first took place. This aligned apprenticeships with the home community of each trainee, increasing success rate.

THRHA recorded recruitment, assessment, and eligibility of applicants, and managed the records of participants who received services under the First Steps program. THRHA conducted training for qualified adult workers who were either underemployed or unemployed. THRHA's target was Alaska Native individuals who had previously worked for THRHA, other construction companies, or in a comparable field and required advanced training for qualifications to meet weatherization program mandates. THRHA selected self-motivated participants who completed the pre-training testing for the weatherization training program. THRHA's training goal was met with over $95 \%$ of participants completing the training and ultimately securing $\mathrm{Wx}$ jobs to weatherize local homes.

\section{Academic/Technical Training Program}

THRHA staff established installer and crew chief training courses in both Juneau and Ketchikan, in addition to an auditor training course in Juneau. THRHA conducted community onsite training in partnership with UAS. UAS was primarily responsible for the Technical Training. All courses met US DOE Core Competencies. Outlines of these courses are attached appendices 1. Participants from southeast Alaska villages received professional training to perform weatherization procedures according to the standards and procedures congruent with the weatherization program.

The training courses were held from 2009 through 2012. Participants received intensive 5-day training programs on weatherization procedures, and repair. Completion of training required a minimum of 40 hours of practical hands-on training linked with classroom training for 150 trainees. Marquam George, weatherization expert and Associate Professor at UAS, lead the training courses. 


\section{Job Training Activities}

Participants received training on weatherization procedures, repair techniques, and proper building material selections, hands-on training that is required as a skill set mandated by the weatherization program. Participants received training to fill employment positions: weatherization installers, supervisors, and auditors.

THRHA and other Wx Service providers hiree qualified candidates at a wage based on current Tribal Wage Rages with actual field work for on the job training purposes. OJT participants participated in all aspects of building weatherization fieldwork according to the technical expertise and classroom training the trainee received as a qualifier for the OJT position. Upon completion of their OJT, THRHA hired weatherization assessors and skilled workers based on established Tribal Wage Rates.

\section{Certificates/Credential}

UAS presented a certificate of completion to each participant that successfully completed a training course. The certificate of completion demonstrates the skill and knowledge as a qualification of hire as weatherization installers, supervisors, and auditors. Successful participants were candidates for increased earnings after completing the training, also the certificate provided trainees with a record of their work.

\section{Job Placement}

Upon completion of training, THRHA directly hired qualified training participants. THRHA also helped other participants find weatherization jobs with other agencies working in their communities: AHFC, ACDC, Alaska Jobs Center. The rapid growth of the weatherization work in southeast Alaska enabled the First Steps Training program to benefit other communities throughout Alaska by hiring participants who successfully completed the weatherization training program. The support of DOE grant funds was substantial in that development of the local workforce enabled individuals to become marketable to multiple employers, ultimately reducing unemployment in local rural communities.

\section{Conclusions and Recommendations}

The wide-range of participant education levels posed circumstance in the Basic Wx training classroom. While the pre-training exam was useful as qualifier for training course acceptance, the wide range of participants' reading, writing, and math skills varied. It is recommended that DOE may consider establishing remedial training courses that are unique to the field of Weatherization. The course could be offered as an online tutorial that can be utilized by the trainee in advance of the Basic Wx Training course, a refresher course to help prepare the trainee for the actual Wx Training. This recommendation has been made directly to Orise and DOE as a support to all Wx Service providers Nationwide.

In conclusion, the First Steps program provided multiple benefits to many individuals, families, communities, and organizations throughout southeast Alaska. THRHA intends to continue its energy education and outreach efforts and build on the accomplishments we've made under this program. THRHA will continue to progress in our work because of the Tribal DOE First Steps funding that has fueled support from the local businesses, Tribes, energy affiliated organizations, utilities, AHFC weatherization program, the Alaska Energy Authority, media, and also residents 
throughout southeast Alaska. THRHA will continue to build productive partnerships that will benefit Tribal citizens throughout southeast Alaska.

\section{Lessons Learned}

While limited circumstances occurred, there were a few individuals enrolled that did not complete the training. This resulted in non-reimbursable expense to THRHA, it is recommended that Tribes provide a deposit for trainee, if Trainee doesn't uphold attendance, then Training Institution utilizes deposit for non-reimbursable expense.

Positive lessons learned include inviting community and funders to participate. THRHA successfully solicited over $\$ 20,000$ in private donations from businesses in Juneau to begin the Weatherization Training Program. This was a great success that spurred the involvement of other organizations to support the work of THRHA including training and programs like "Energy Cents". THRHA will continue to funding from private and public sources to continue the weatherization training program. The Tribal DOE First Steps program truly is the first step in attaining and achieving many more programs and accomplishments as result of this first grant that set everything else in motion!

\section{Appendices}

1. Course Outlines, Energy Conservation Behavioral Modification Training (add-on), Goals

2. Lecture Slides Example

3. Trainee Application Packet Example

4. Outreach Examples

5. Articles / News Examples

6. Attendance Form / Pre-Post Test examples 
Appendices 1

Energy efficiency training courses 
Outline

Weatherization Technician I

This five day course is designed to introduce the individual to weatherization job readiness and material installation techniques by the use of both classroom instruction and "handson" laboratory experience. This course is primarily for new weatherization employees, but is open to anyone who would benefit from a basic understanding of typical weatherization retrofit measures. Topics covered include: Buildings as a system theory, appropriate air sealing materials and installation techniques, insulation types and applications, and basic blower door use. Building Performance Institute Building Analyst Certification components are included in this class.

Day 1

Principals of Cold Climate Building Science (Classroom 4 hrs)

Principals of heat flow

Types of heat flow; conduction, convection, and radiation

Reasons for heat flow; stack, wind, flue, and ventilation effects

Understanding temperature/relative humidity and comfort

Insulation and Airsealing Materials (Classroom $4 \mathrm{hrs)}$

Moisture and heat flow characteristics of insulation products

Conduction convection and radiation effects of insulations

Fiberglass \& cellulose; batt, rigid, loose, blown, and dense-packed

Foam insulation; spray or rigid

Tolerances; moisture, durability, UV, and critters

Materials and permeability

Air barriers, vapor barriers, and vapor retarders

Day 2

Insulating and Airsealing a Building (In-Field 8 hrs)

Airsealing; where, how, and what with

Skirting insulation methods

Insulating and airsealing rim joists

Insulating and airsealing floors

Insulating and airsealing exterior walls

Airsealing interior walls

Airsealing marriage lines, common walls

Airsealing and insulating attics 
Day 3

Effective Airsealing (Classroom 2 hrs)

Understanding thermal and pressure boundaries

Using a blower door

Airsealing and CFM50

Building Tightness Limit (Classroom 2 hrs)

Calculating building tightness limit

Assessing Airsealing Efforts (In-Field $4 \mathrm{hrs}$ )

Setting up a blower door for weatherization

Reading a manometer

Understanding CFM50

Day 4

Ventilation (In-Field 2 hrs)

Installing airtight and effective ductwork

Understanding fans and flows

Control strategies

Combustion Safety (In-Field 2 hrs)

Combustion appliance categories

Combustion appliance safety

CO monitors

Cladding, Flashings, and Weather Barriers (Classroom 2 hrs)

Keeping wind and rain out of the building

Air barriers \& weather barriers; what's the difference

Installation and durability considerations of air and weather barriers

Weather barriers, flashings and gravity

Drainage, drying, or both

Ventilated cladding techniques

Moisture Damaged Materials (Classroom 2 hrs)

Sources of moisture problems

When mold is found; health and safety

Best practices for eliminating potential recurrences

Day 5

Replacing Doors and Windows (Classroom 2 hrs)

Where windows leak

Heat loss and solar gain through windows

Gas fills, coatings, edge-effect, frame effect, and spacer technology

Design, orientation, and installation details for windows and doors

Installing windows and doors; integrating into drainage planes 
Air sealing rough openings

Introduction to AkWarm (Classroom $1 \mathrm{hr}$ )

Where improvement options come from

Professional Conduct (Classroom $1 \mathrm{hr}$ )

Respect of property and possessions

First impressions; presenting one's self in a professional manner

Test Out (In-Field 4 hrs)

Participants will each lead the class in a set-up and repair component 
OUTLINE

Weatherization Crew Chief Training

This five day training takes pressure diagnostics and weatherization skills to the next level. Participants will advance their knowledge with a manometer and other tools to evaluate flue safety performance and pressure imbalances of forced air systems.

Detecting air leakage paths through zonal testing, and duct leakage through pressure pan testing will also be covered. The course will utilize both lecture and hands on activities.

Day 1

Building Moisture Processes (Classroom 2 hrs)

Fixing or creating condensation and moisture problems

Determining Pressure and Thermal Boundaries (Classroom $2 \mathrm{hrs}$ )

Testing and verifying boundaries

Using a digital manometer

Blower Door Zonal Diagnostics (In-Field 4 hrs)

Pressure testing house to crawl space

Pressure testing house to attic

Pressure testing exterior walls

Pressure testing interior walls

Pressure testing dropped knee walls, ceilings \& soffits

Day 2

Understanding and Evaluating Pressure Diagnostics (Classroom 2 hrs)

Setting scope of work actions based on pressure readings

Heating and Domestic Hot Water (Classroom 4 hrs)

Heating fundamentals

Calculating heat loss

Comparison and attributes of different fuel sources and heating systems

Control options

Combustion Safety (In-Field 4 hrs)

Diagnostic tools and their functions

Heat exchanger test procedures

Testing flue pressures

Testing water heaters

Worst-case depressurization of combustion appliance zone

Domestic Hot Water Diagnostics (In-Field 2 hrs)

Calculating tank losses 
Methods to save energy with hot water heaters \& distribution

systems

Day 3

Duct Leakage Testing (In-Field 8 hrs)

Setting up for duct pressurization testing

Setting up for duct depressurization testing

Total leakage pressurization test method

Leakage to outside pressurization testing

Determine dominant duct leakage

Finding duct leaks; smoke test \& pressure pan testing

Measuring room to room pressures

Estimating duct leaks to the outside using blower door subtraction

Day 4

Evaluating \& Validating Assessments and Improvements (Classroom 2 hrs)

Selecting the tasks for health, safety, durability, and

energy savings improvement options

AkWarm as a modeling tool

Ventilation Systems (In-Field 4 hrs)

Calculate ventilation requirements, building tightness limit

Installing ventilation systems to work

Ventilation controls

Measuring ventilation airflows

Dealing with Decay (In-Field 2 hrs)

Health and safety when working with moisture damaged materials

Day 5

Test Out (In-Field 6 hrs)

Participants will each lead the class in a set-up and testing protocol

Written Exam (Classroom 2 hrs) 


\section{Energy Cents Training Outline for 28 trainees, September 2012}

a) how to conduct a household energy usage assessment,

b) determine what assessment equipment will be used and how to use energy usage monitoring equipment,

c) how to educate and help occupants save household energy

d) how to gather and record individual household baseline data,

e) how to determine what measurements and criteria will be used for proposing change to address household needs,

f) what data will be used (and how) to compile compelling cases for funding needed to address the specific household needs identified as part of the assessment,

g) how to work with local schools k-12 to incorporate long-term community involvement and continuing energy conservation behavior

h) what role and how the EC Crew will serve in community awareness and coordination of their community energy fair

i) other education/training according to the Energy Wise Program curriculum, UAS, Healthy Homes, and maintenance assessment of infrastructure. 


\section{Alaska Native Weatherization Training and Jobs Program \\ U.S. Department of Energy Award Number DE-EE0002526 \\ Grant Period 1/01/2010 thru 3/31/2013}

\section{Activities Goals}

$5 \mathbf{w x}$ trainings (installers, crew chiefs, supervisors, and auditors)

50 Alaska Native Trainees

25 paid apprenticeships

DOE Core Competencies

Alaska Native residents

UAS Classroom training

THRHA apprenticeships

\section{Recruitment}

- THRHA completes the outreach

- Applicant understanding of basic competencies and a demonstrated work ethic.

- Applicant provides a description of their work history and/or academic background

- A commitment is entered; training requirements and expectations

- Training to fill jobs; weatherization installers, supervisors, and auditors.

\section{Training Program}

- Classroom: intensive 5-day training; wx procedures and repair, minimum of 40 hours.

- On-the-Job Training: Paid OJT provided by THRHA OJT paid time $=108.8$ hours $=\$ 48,960$.

\section{Job Placement}

- THRHA will directly hire qualified training participants.

- THRHA will help participants find weatherization jobs with other agencies: AHFC, ACDC, Rural Cap, Alaska Jobs Center, EECBG Tribal Programs and other Wx Service Providers. 


\section{TASKS TO BE PERFORMED}

- THRHA create documents; trainee application, pre-test, trainee commitment

- THRHA outreach to qualified Alaska Native applicants (outreach to over 200)

- applicant pool of about 100 potential trainees (20 for each of the five courses).

- Pre-test qualification for training

- $\quad$ THRHA will select a total of 60 participants (12 students per training)

- $\quad$ THRHA will identify 4 alternates (waitlist) for each of the 5 trainings

- Outreach and identification of participants will occur in a timely manner before each training session

- $\quad$ THRHA will work with selected applicants to determine which session they will attend. Individuals may participate in more than one training session or apprenticeship, however, they do not have to do so in order to obtain employment.

- Session selection depends on applicant's qualifications, schedule and home community, and session location.

- UAS will conduct technical training courses for installer and crew chief at UAS Juneau and Ketchikan campuses.

- $\quad$ The auditor course will be held at the UAS Juneau campus.

- UAS will provide instruction material and equipment for training sessions.

- THRHA will provide a total of 25 four week paid apprenticeships with THRHA crews for trainees who have successfully completed UAS training.

- Paid apprenticeships will be arranged by THRHA.

- THRHA will assist successful trainees in deciding which apprenticeship is best for them.

\section{Reporting Requirements}

- comparison of the actual accomplishments with the grant goals and objectives

- Cost Status.

- Cost sharing break (record all cost share expenses and personnel hours)

- Schedule Status.

- $\quad$ significant changes to the objectives and scope require prior approval by DOE.

- Any absence or changes of key personnel or changes in consortium/teaming arrangement.

- A description of any product produced or technology transfer activities accomplished

- during this reporting period, such as: Publications (list journal name, volume, issue); conference papers; or other public releases of results, Web site or other Internet sites that reflect the results of this project. 
1 Story on pilings, Well shielded, Flat ceiling, No skirting.

3 Bedrooms, 5 Occupants, CFM50 569

Footprint : $19^{\prime} \times 48^{\prime}$

Wall Height: 8'1"

Heated Floor Area:

Heated Volume:

Surface Area:

Person- BTL CFM50:

Bedroom- BTL CFM50:

Volume- BTL CFM50:

Trailer, Normal exposure, Skirted but not insulated, Flat ceiling.

2 Bedrooms, 1 Occupant, CFM50 1133

Footprint: 23' x 43'

Wall Height: 7'6"

Heated Floor Area:

Heated Volume:

Surface Area:

Person- BTL CFM50:

Bedroom- BTL CFM50:

Volume- BTL CFM50:

1 Story on pilings, Exposed, Flat ceiling, No skirting,

3 Bedrooms, 4 Occupants, CFM50 2092

Footprint: $28^{\prime}$ x 64'

Wall Height: 8'

Heated Floor Area:

Heated Volume:

Surface Area:

Person- BTL CFM50:

Bedroom- BTL CFM50:

Volume- BTL CFM50:

1 Story on crawlspace, Normal exposed, Flat ceiling.

3 Bedrooms, 4 Occupants, CFM50 669

Footprint : $25^{\prime} \times 50^{\prime}$

Wall Height: 8'1"

Heated Floor Area:

Heated Volume:

Surface Area:

Surface Area:

Person- BTL CFM50:

Bedroom- BTL CFM50:

Volume- BTL CFM50: 
Trailer, Exposed, Skirted but not insulated, Flat ceiling.

3 Bedrooms, 6 Occupants, CFM50 1633

Footprint: $23^{\prime}$ x 43'

Wall Height: 7'6"

Heated Floor Area:

Heated Volume:

Surface Area:

Person- BTL CFM50:

Bedroom- BTL CFM50:

Volume- BTL CFM50:

1 Story on crawlspace, Well shielded, Flat ceiling

3 Bedrooms, 5 Occupants, CFM50 1704

Footprint: $28^{\prime} \times 44^{\prime}$

Wall Height: 8'

Heated Floor Area:

Heated Volume:

Surface Area:

Person- BTL CFM50:

Bedroom- BTL CFM50:

Volume- BTL CFM50:

1 Story on pilings, Exposed, Flat ceiling, No skirting.

3 Bedrooms, 1 Occupant, CFM50 700

Footprint : $19^{\prime} \times 36^{\prime}$

Wall Height: 7'6"

Heated Floor Area:

Heated Volume:

Surface Area:

Person- BTL CFM50:

Bedroom- BTL CFM50:

Volume- BTL CFM50:

Trailer, Skirted but not insulated, Flat ceiling.

2 Bedrooms, 2 Occupants, CFM50 1133

Footprint: $20^{\prime}$ x 40'

Wall Height: 7'6"

Heated Floor Area:

Heated Volume:

Surface Area:

Person- BTL CFM50:

Bedroom- BTL CFM50:

Volume- BTL CFM50: 
1 Story on pilings, Exposed, Flat ceiling, No skirting,

3 Bedrooms, 4 Occupants, CFM50 2005

Footprint: $28^{\prime} \times 48^{\prime}$

Wall Height: 8' $^{\prime}$

Heated Floor Area:

Heated Volume:

Surface Area:

Person- BTL CFM50:

Bedroom- BTL CFM50:

Volume- BTL CFM50:

1 Story on pilings, Normal exposure, Flat ceiling, No skirting.

3 Bedrooms, 3 Occupants, CFM50 942

Footprint : 19' x 48'

Wall Height: 8'1"

Heated Floor Area:

Heated Volume:

Surface Area:

Person- BTL CFM50:

Bedroom- BTL CFM50:

Volume- BTL CFM50:

Trailer, Well Shielded, Skirted but not insulated, Flat ceiling.

2 Bedrooms, 2 Occupants, CFM50 1810

Footprint: $23^{\prime} \times 43^{\prime}$

Wall Height: 7'6"

Heated Floor Area:

Heated Volume:

Surface Area:

Person- BTL CFM50:

Bedroom- BTL CFM50:

Volume- BTL CFM50:

2 Story on pilings, Exposed, Flat ceiling, No skirting, 3 Bedrooms, 4 Occupants, CFM50 2363

Footprint: $28^{\prime} \times 32^{\prime}$

Wall Height: 8'

Floor Joists: 2" x 10"

Heated Floor Area:

Heated Volume:

Surface Area:

Person- BTL CFM50:

Bedroom- BTL CFM50:

Volume- BTL CFM50: 


\section{Building Tightness Limit (BTL)}

1. Find your climate zone on the map.

2. Match that zone number with the same zone number on the table.

3. Identify the site as well-shielded, normal, or exposed.

4. Identify the column for your building's number of stories.

5. Follow that column down to where it meets the row corresponding to your climate zone and shielding to find n.

6. Use $\mathrm{n}$ to convert 50 Pascal airflows to natural or vice versa.

7. Find the building tightness limit (BTL). 


\section{Formulas}

$\mathrm{ACHn}=\quad \underline{\mathrm{ACH}_{50}}$

$n$

$\mathrm{ACH}_{50}=\quad \mathrm{ACHn} \times \mathrm{n}$

CFMn $=\frac{\text { CFM }_{50}}{\mathrm{n}}$

CFM50 $=\quad$ CFMn $\times n$

BTL (CFM50) X \# of occupants X $n$ 


\section{Climate Zone}

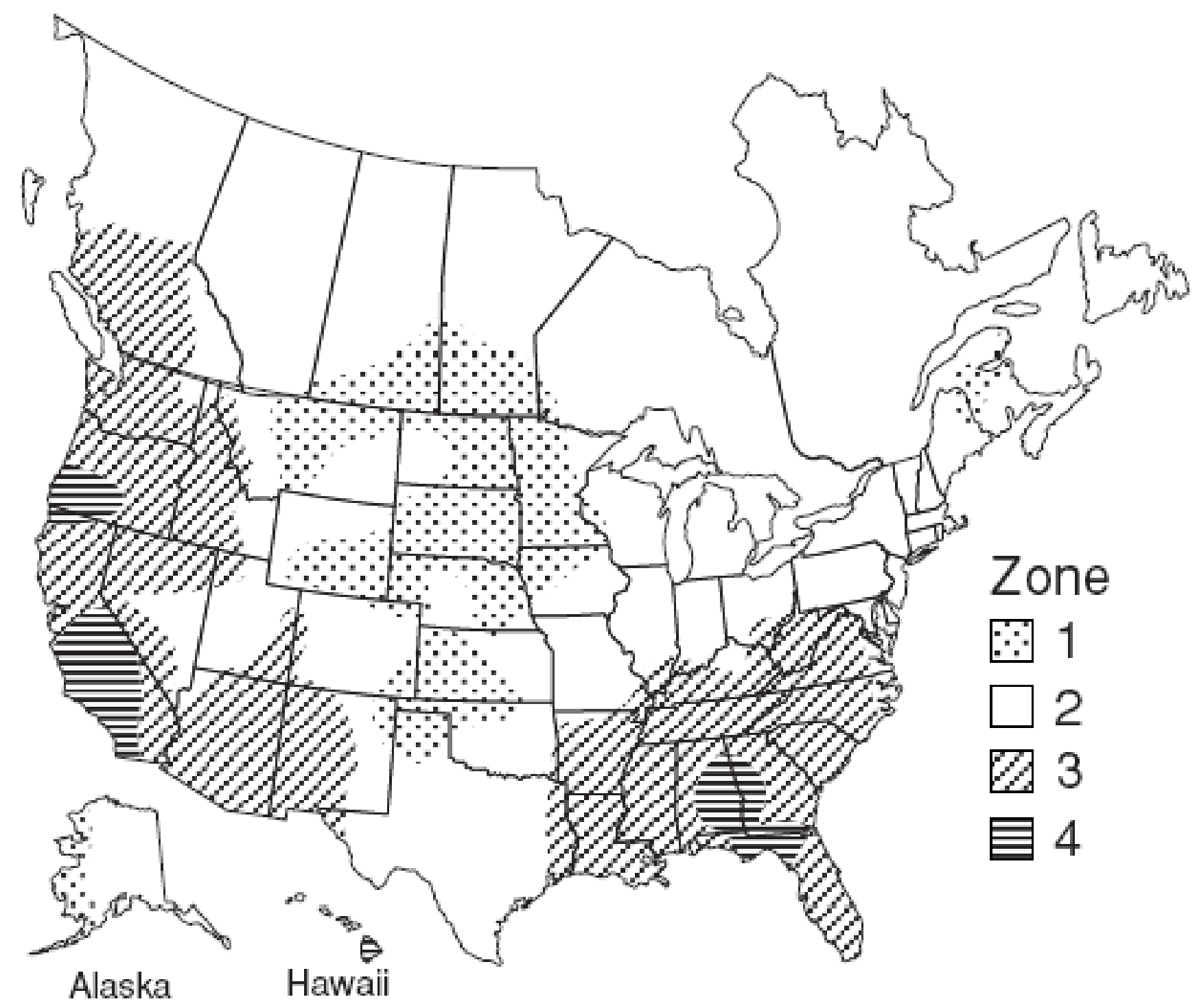




\section{n-Factor Table}

\begin{tabular}{|c|c|c|c|c|c|}
\hline Zone & $\#$ of stories $\rightarrow$ & 1 & 1.5 & 2 & 3 \\
\hline & Well-shi & 18.6 & 16.7 & 14.9 & 13.0 \\
\hline & Normal & 15.5 & 14.0 & 12.4 & 10.9 \\
\hline & Exposed & 14.0 & 12.6 & 11.2 & 9.8 \\
\hline \multirow{3}{*}{2} & Well-shie & 22.2 & 20.0 & 17.8 & 15.5 \\
\hline & Normal & 18.5 & 16.7 & 14.8 & 13.0 \\
\hline & Exposed & 16.7 & 15.0 & 13.3 & 11.7 \\
\hline \multirow{3}{*}{3} & Well-shielded & 25.8 & 23.2 & 20.6 & 18.1 \\
\hline & Normal & 21.5 & 19.4 & 17.2 & 15.1 \\
\hline & Exposed & 19.4 & 17.4 & 15.5 & 13.5 \\
\hline \multirow{3}{*}{4} & Well-shielded & 29.4 & 26.5 & 23.5 & 20.6 \\
\hline & Normal & 24.5 & 22.1 & 19.6 & 17.2 \\
\hline & Exposed & 22.1 & 19.8 & 17.6 & 15.4 \\
\hline
\end{tabular}




\section{Determining Minimum Ventilation Rate}

Formula \#1: $\quad 15 \mathrm{cfm} x$ the number of occupants $\times n=$ CFM50 BTL

Formula \#2: $\quad 15 \mathrm{cfm} \times$ number of bedrooms

$+15 \times n=$ CFM50 BTL

Formula \#3: $\quad$ Volume of conditioned space $x$ $0.35 \times \mathrm{n} / 60=$ CFM50 BTL 


\title{
Glossary
}

\section{A}

Above Grade Wall (Exterior)

Any above grade portion of the thermal enclosure that makes an angle of 60 degrees or more from the horizontal.

Absolute Humidity

Air moisture content expressed in grains (or pounds) of water vapor per pound of dry air.

\author{
Absorptance \\ The ratio of a solar energy absorbed to incident solar. Also called \\ absorbtivity.
}

Absorption

A solid material's ability to draw in and hold liquid or gas.

Accent Lighting

Accent lighting illuminates walls, reduces brightness and contrast between walls and ceilings or windows.

Adsorption

Adhesion of a thin layer of molecules to a surface they contact.

Air Barrier

Any part of the building shell that offers resistance to air leakage. The air barrier is effective if it stops most air leakage. The primary air barrier is the most effective of a series of air barriers.

Air Changes per Hour at 50 Pascals

The number of times the volume of air in a structure will change in one hour at the induced blower door house pressure of 50 pascals.

Air Exchange

The total building air exchanged with the outdoors through air leakage and ventilation.

Air Handler

A steel cabinet containing a blower with cooling and/or heating coils connected to ducts that transport indoor air to and from the air handler.

Air Infiltration Barrier

A woven plastic sheet that stops almost all air traveling through a building cavity, while allowing moisture to pass through the cavity. 


\section{Air Sealing}

Also known as "house doctoring," air sealing is a systematic approach to "tightening" a dwelling unit's heated envelope (building shell) to reduce uncontrolled heat loss through air leakage points present in the shell. The prevalent technique is to perform this tightening from the interior of the home. Trained workers seal the air leakage points using a variety of materials, such as insulation, caulk, foam, vapor barriers, and weather-strip. Air leakage identification is usually aided by using diagnostic equipment like blower doors and infrared scanners, since many leakage point are not obvious to the naked eye. Part of the air sealing protocol includes testing to ensure that the building envelope is not sealed too tightly. Over-tightening can result in health and safety problems for the occupants, including back drafting of combustion equipment (furnaces, hot water heaters) and moisture condensation causing mold and mildew on surfaces.

Ambient Lighting Lighting spread throughout the lighted space for safety, security, and aesthetics.

Ampere

A unit of measure for the flow of electric current

Annual Fuel Utilization Efficiency (AFUE)

A laboratory-derived efficiency for heating appliances that accounts for chimney losses, jacket losses, and cycling losses, but not distribution losses or fan/pump energy.

Annual Return

The yearly savings divided by the initial cost needed to achieve the savings, expressed as a percent.

\section{Aquastat}

A heating control device that controls the burner or the circulator in a hydronic heating system

\section{Asbestos}

A material made of sharp mineral fibers that damage lung and other bodily tissues.

\section{ASHRAE}

American Society of Heating, Refrigeration, and Air Conditioning Engineers

\section{ASTM}

American Society for Testing and Materials 
Attic Insulation

The installation of approved insulation products (rockwool, fiberglass, and cellulose) evenly across the unconditioned attic area to achieve desired levels of thermal resistance. Insulation products have manufacturer rated " $R$ " levels (resistance to heat loss measurements). The more inches of insulation installed the higher the resistance level. The recommended " $R$ " values vary by climatic regions of the country. It is common for weatherization programs to install a minimum of R-19 or as much as R-38 in colder regions. The cost-effective level of insulation to be added, if any, depends on the existing level of insulation in the attic. Auditors determined the amount of insulation to be added through prescriptive lists or energy audit programs that calculate the saving to investment ratio from increasing insulation levels.

\section{Attic Preparation}

This refers to the protocol for inspecting and preparing an attic area for the installation of insulation. The preparatory work is directed primarily to air infiltration and safety issues. Some of the protocols include placing barriers around heat-producing sources in the attic (electrical junction boxes, recessed lights, etc.); placing chutes by the eaves to prevent the insulation from blocking needed air ventilation paths; and sealing bypasses and other penetrations between the heated space and the unconditioned attic area.

Audit The process of identifying energy conservation opportunities in buildings.

AWG American Wire Gauge

\section{B}

Back-drafting Continuous spillage of combustion gases from a combustion appliances

Back-draft Damper

A damper, installed near a fan, that allows air to flow in only one direction.

Backer Rod

Polyethylene foam rope used as a backer for caulking.

Baffle

A plate or strip designed to retard or redirect the flow of flue gases. Balance point - The outdoor temperature at which no heating is needed. 
Balance Heating

This is the result of balancing the airflow of the central heating distribution system so that intake and output air exists at levels to maximize efficiency. The balancing of the distribution system assures that all areas of the home being served by the same heating or cooling system or any zone within the system receive approximately equal heated or cooled air.

Ballast

A coil of wire or electronic device that provides a high starting voltage for a lamp and limits the current flowing through it.

Balloon Framing

A type of framing where the first-floor studs continue upward, unbroken, past the second-floor joists, to become the secondfloor studs as well. A ledger is used to support the second-floor joists.

Band Joist

See - Rim Joist

Batt

A narrow blanket of fiberglass insulation, generally 14.5 " or $22.5 "$ wide.

Beam

A strong horizontal building support used to carry the weight of a floor or roof.

Bimetal Element

A metal spring, lever, or disc made of two dissimilar metals that expand and contract at different rates as the temperature around them changes. This movement operates a switch in the control circuit of a heating or cooling device.

\section{Blower Door}

A blower door is a diagnostic tool used to locate the points of infiltration in the building envelope and help prioritize the air sealing protocols. This device can be mounted in an exterior door or window opening. The blower door uses a calibrated, powerful, variable speed fan to pressurize or depressurize the dwelling. Its adjustable frame allows the fan assembly to fit snugly in most frames. Air movement and pressure differentials are measured using a set of gauges attached to the frame and fan. These calculations of air movement allow technician to quantify the level of leakage. Such leakage measurements are usually expressed in terms of equivalent leakage area (ELA), air changes per hour $(\mathrm{ACH})$, and cubic feet per minute of airflow (CFM). Any one or more of these measurements can help determine levels of air leakage, indoor air quality, and amount of sealing work to be performed. In addition to measuring air movement, the blower 
door will exaggerate the leakage points in the building shell for easy identification. This diagnostic tool, when used in conjunction with an infrared scanner, produces even more accurate results.

Blow-Down

The act of removing water from a boiler to remove sediment and suspended particles.

\section{Blower Fan}

The squirrel-cage fan in a furnace or air handler.

Boiler

A fossil fuel appliance used for producing hot water or steam as the medium to distribute heat to the dwelling unit.

Boot

A duct section that connects between a duct and a register or between round and square ducts

Branch Circuit

An electrical circuit used to power outlets and lights within a home.

\section{Brightness}

The intensity of the sensation derived from viewing a lit surface. Measured in foot lamberts, it is also called luminance or luminous intensity.

\section{British Thermal Unit (Btu)}

The quantity of heat required to raise the temperature of one pound of water one degree Fahrenheit.

\section{Building Cavities}

The spaces inside walls, floors, and ceilings between the interior and exterior sheeting

Building Envelope

The area of the building that encloses conditioned space. Only the exterior four walls to the ceiling under the attic and the floor above the unheated basement area are considered part of the building envelope. The floor of a unit that is built on stilts or is above an unheated crawl space is considered a part of the building envelope. The roof of a building that has no ceilings (or that is part of the ceiling) is considered part of the building envelope.

\section{Building Science}

Branch of science dealing with construction, maintenance, safety, and energy efficiency of buildings.

Burner

A device that facilitates the burning of a fossil fuel, like gas or oil. 
Carbon Dioxide

One of two main products of complete combustion of a

hydrocarbon (the other is water vapor).

Carbon Monoxide (CO)

Carbon Monoxide is a tasteless, odorless, colorless and poisonous

gas that is a by-product of incomplete combustion of fossil fuels. It

is usually caused by a lack of air to support combustion or

impingement of the flame.

Casing

Exposed molding or trim around a window or door.

Caulking

Mastic compound for filling joints and cracks.

Cellulose Insulation

Insulation, packaged in bags for blowing, made from newspaper or wood waste and treated with a fire retardant

Centigrade

A temperature scale on which water freezes at 0 degrees and boils at 100 degrees

Central Heating System

This refers to the primary heating system of the dwelling unit including the heat producing appliance, the return and supply system for heat distribution, and ducts or pipes for flue gas ventilation. Central heating systems usually do not include wood stoves, kerosene heaters, space heaters, and electric baseboard heating units.

\section{CFM50}

This term means the amount of cubic feet per minute of air moving through a structure and measured at 50-pascal pressure.

\section{CFMn}

The cubic feet of air flowing through a house from indoors to outdoors during typical, natural conditions. This figure can be roughly estimated using a blower door.

CFM Per Person or Per Room

An estimate of the cubic feet per minute of fresh air available or required per occupant or per room.

CFM - Cubic Feet per Minute.

Usually expressed as CFM50, cubic feet per minute of air movement due to 50 pascal house/outdoor pressure differential. 
Circuit Breaker

A device found in a Circuit Panel Box that completes an electric circuit. This breaker disconnects the circuit from electricity when it senses an overload of current.

Clean and Tune (C\&T)

A procedure performed on a heating system by a licensed furnace service technician to maximize the appliance efficiency using existing hardware. The C\&T is usually preceded by a combustion efficiency test to assess whether other conditions exist requiring extensive furnace work. The C\&T can involve a variety of activities to upgrade the efficiency and safe operation of the heating system. These can include pilot and burner adjustment, adjustment of ventilation and combustion, check and reset controls, inspect filters, lubricate motors, flush low water cut-off, check operation of steam and water relief valves, check thermostat, check safety valve, and check thermocouple.

Co-efficient of Performance (COP)

A heat pump or air conditioner's output in watt-hours of heat moved divided by watt-hours of electrical input.

Coil

A snake-like piece of copper tubing surrounded by rows of aluminum fins that clamp tightly to the tubing and aid in heat transfer.

Color Rendering Index (CRI)

A measurement of a light source's ability to render colors the same as sunlight. CRI has a scale of 0 to 100 .

Color Temperature

A measurement of the warmness or coolness of a light source in the Kelvin temperature scale.

Column

A vertical building support usually made of wood or steel.

Combustible

Means something will burn, although not necessarily readily.

Combustion Air

Air that chemically combines with a fuel during the combustion process to produce heat and flue gases, mainly carbon dioxide and water vapor.

Combustion Analyzer

A device used to measure steady-state efficiency of combustion heating units. 
Combustion Chamber

The area inside the heat exchanger where the flame burns

Combustion Test

This test is performed to determine the efficiency at which a heating appliance is operating at steady state. The actual tests or sequence of tests may vary in conjunction with the type of testing equipment used or the type of heating appliance being tested.

Persons performing these tests must be extremely familiar with the testing equipment being used and must be trained in conducting the tests. In some states, a license is required to perform such tests.

Compressor

A motorized pump that compresses the gaseous refrigerant and sends it to the condenser where heat is released

\section{Condense}

When a gas turns into a liquid as it cools, it condenses. Condensation is the opposite of evaporation. When a gas condenses into a liquid it releases heat.

\section{Condenser}

The coil in an air conditioning system where the refrigerant condenses and releases heat, that is carried away by air moving through the coil.

\section{Condensate}

Vapor condensed back to a liquid.

\section{Condensate Receiver}

A tank for catching returning condensate water from a steam heating system.

\section{Conditioned}

Intentionally heated or cooled areas of a building

Conductance

The property of a material to conduct some energy form like heat or electricity.

\section{Conduction}

Conduction is the transfer of heat through a material by molecular movement. Reducing heat loss through conduction can include the installation insulation in wall, ceiling, and floor cavities, insulation of hot water tanks, creating thermal breaks in window and door framing, and sealing of bypasses and other sources of air movement. 


\section{Contrast}

Difference in brightness measured by the relationship between an object's brightness and the brightness of its background.

\section{Control Circuit}

A circuit whose work is switching a power circuit or opening an automatic valve

\section{Convection}

The transfer of heat caused by the movement of a fluid like water or air. When a fluid becomes warmer it becomes lighter and rises.

\section{Convective Air Flow}

Air movement where less dense (warmer) air is displaced by more dense (cooler) air. Often expressed by the phrase "hot air rises." Convective air flow can be useful if controlled, as in gravity hot air heating systems, but is more often a contributor to heat loss.

\section{Convective Loop}

A structural heat loss resulting from temperature differences between the inside and outside wall surfaces causing an air movement loop within the wall cavity. This condition can be present when a stud cavity has no insulation. Air in the cavity is heated near the interior surface of the wall, rises, circulates back toward the exterior siding, falls, re-circulates back to the warm side, is re-heated, and so on.

\section{Cooling Load}

The maximum rate of heat removal required of an air conditioner when the outdoor temperature and humidity are at the highest expected level.

\section{Cost Effective}

Having an acceptable payback, return-on-investment, or savingsto-investment ratio.

\section{Cross Section}

A view of a building component drawn or imagined by cutting through the component.

\section{CSBG - Community Services Block Grant}

The Community Services Block Grant (CSBG) is federal, antipoverty block grant which funds the operations of a stateadministered network of local agencies. This CSBG network consists of more than 1,100 agencies that create, coordinate and deliver programs and services to low-income Americans in $96 \%$ of the nation's counties.

Most agencies in the CSBG network are Community Action Agencies (CAAs), created through the Economic Opportunity Act, a predecessor of the CSBG. Community representation and accountability are hallmarks of the CSBG network, where agencies 
are governed by a tri-partite board. This structure consists of elected public officials, representatives of the low-income community, and appointed leaders from the private sector. Because the CSBG funds the central management and core activities of these agencies, the CSBG network is able to mobilize additional resources to combat the central causes of poverty.

Cubic Foot Per Minute (CFM)

A measurement of air movement past a certain point or through a certain structure

\section{Curtain Wall}

A wall between columns and beams that supports no weight but its own

\section{Customer Certification}

A final determination concerning program eligibility based on income and ownership, resulting in the customer's receipt or denial of WAP benefits.

\section{D}

Dado

A rectangular groove cut into wood.

\section{Decking}

The wood material installed under roofing material to support the roofing.

Demand for Energy

The peak need for electrical energy. Some utilities levy a monthly charge for demand.

Demand Side Management (DSM)

The planning and implementation of those utility sponsored activities designed to influence customer use of electricity or gas in ways that will produce desired changes in the utility's load shape, such as changes in the pattern and magnitude of the utility's load. DSM study has resulted in a variety of utilitysponsored programs to redirect their customer's usage patterns, especially in the peak load periods. While mainly an electric utility applied concept, there is some application to gas utilities as well. The ultimate goal for most utilities is to avoid the need to invest in new power plants or distribution due to excessive demands on current capacity.

Density

The weight of a material divided by its volume, usually measured in pounds per cubic foot. 
Degree Days

A measure of the temperature element of climate produced by multiplying temperature difference by time.

Depressurize

Cause to have a lower pressure or vacuum with respect to a reference of a higher pressure.

Desiccant

A liquid or solid material used to absorb water or water vapor.

Design Temperature

A high or low temperature used for designing heating and cooling systems.

Dew Point

The warmest temperature of an object in an environment where water condensation from the surrounding air would form on that object

\section{Dilution Air}

Air that enters through the dilution device-an opening where the chimney joins to an atmospheric-draft combustion appliance

Dilution Device

A draft diverter or barometric draft control on an atmosphericdraft combustion appliance.

Distribution System

This term refers to that part of a central heating system used to deliver heated transfer media to the living space, and return the cooled transfer media to the appliance for re-heating. In a forced air system this includes the blower, ducts, registers, dampers, and cold air returns. In a hot water system this includes circulators, supply lines, radiators, and return lines.

Domestic Hot Water (DHW)

Refers to a separate, closed system to heat potable (drinkable) water and supply it to the dwelling unit for washing, bathing, etc.

Dormer

A vertical window projecting from a roof.

Draft Diverter

A device located in gas appliance flue pipe. Used to moderate or divert draft that could extinguish the pilot or interfere with combustion 


\section{Drywall}

Gypsum interior wallboard used to produce a smooth and level interior wall surface and to resist fire. Also called gypsum wall board or sheetrock.

Dry Bulb Temperature

Normal ambient air temperature measured by a thermometer.

\section{Duct Blower}

A blower-door-like device used for testing duct leakiness and air flow.

Duplex

Any structure which consists of two separate dwelling units in one building.

Dwelling Unit A house, including a stationary mobile home, an apartment, a group of rooms, or a single room occupied as separate living quarters.

\section{$\mathbf{E}$}

Eaves

The lower edges of a roof system (See - Soffit)

\section{Efficiency}

The ratio of output divided by input

\section{Efficacy}

The number of lumens produced by a watt used for lighting a lamp. Used to describe lighting efficiency.

Eligible Multi-Family Dwelling Units

A multi-family building qualifies to be weatherized in its entirety when $66 \%$ (50\% for 2 and 4 unit buildings) or more of the total dwelling units in the building are determined to be eligible as per DOE rules.

\section{Eligible Unit}

A unit occupied by a household that is categorically eligible or income eligible by DOE and/or LIHEAP standards.

Emittance

The ability of a material to emit radiant energy from its surface. Also called emissivity.

Energy

A quantity of heat or work 
Energy Consumption

The conversion or transformation of potential energy into kinetic energy for heat, light, electricity, etc.

Energy Education

The process used by WAP staff to inform customers of the ways they can further reduce energy consumption through altering their behavioral patterns. The most effective protocol includes multiple interaction and reinforcement with the household residents and use of a negotiated and written action plan.

Energy Efficiency

Term used to describe how efficiently a building component uses energy.

Energy Efficiency Ratio (EER)

A measurement of energy efficiency for room air conditioners. The EER is computed by dividing cooling capacity, measured in British Thermal Units per hour (Btuh), by the watts of power. (See Seasonal Energy Efficiency Rating or SEER)

Enthalpy

The internal heat of a material measured in Btus per pound.

Entropy

Heat unavailable to a closed thermodynamic system during a heat transfer process.

EPA

U.S. Environmental Protection Agency

EPA's mission is to protect human health and to safeguard the natural environment - air, water, and land - upon which life depends. For 30 years, EPA has been working for a cleaner, healthier environment for the American people.

Equivalent Leakage Area (ELA)

Calculation, in square inches, of the total area of all holes and cracks in a structure. The leakage area is then accumulated to represent one total leakage point.

Evaporation

The change that occurs when a liquid becomes a gas. Evaporation is the key process in the operation of air conditioners and evaporative coolers.

Evaporative Cooler A device for cooling homes in dry climates by humidifying and cooling incoming air. 
Evaporator

The heat transfer coil of an air conditioner or heat pump that cools the surrounding air as the refrigerant inside the coil evaporates and absorbs heat.

Exfiltration

This term describes the movement of air out of a building. Often refers to warm air leaving a building due to pressurization, infiltration, wind, stack effect, and/or convective flow.

$\mathbf{F}$

Fahrenheit

A temperature scale used in the United States and a few other countries. On the Fahrenheit scale, water boils at 212 degrees and freezes at 32 degrees.

Family Unit

All persons living together in a dwelling unit

Fan Control

A bimetal thermostat that turns the furnace blower on and off as it senses the presence of heat.

FEMP

Federal Energy Management Program

A program of DOE that implements energy legislation and presidential directives. FEMP provides project financing, technical guidance and assistance, coordination and reporting, and new initiatives for the federal government. It also helps federal agencies identify the best technologies and technology demonstrations for their use.

Fenestration

Window and door openings in a building's wall.

Fiberglass

A fibrous material made by spinning molten glass used as an insulator and heat loss retardant

Fill Tube

A plastic or metal tube used for its stiffness to blow insulation inside a building cavity.

Fin Comb

A comb-like tool used to straighten bent fins in air conditioning coils.

Fire Stop

Framing member designed to stop the spread of fire within a wall cavity. 
Flame Safety Control

A control device used to stop the flow of fuel to the burner assembly in the event of no ignition.

Flashing

Waterproof material used to prevent leakage at intersections between the roof surface at walls or penetrations.

Floor Joists

The framing members that support the floor area.

Flue

The channel of pipe used to control air flow of combustion gases.

Foam Board

Plastic foam insulation manufactured most commonly in 4' $x 8^{\prime}$ sheets in thickness of $1 / 4$ " to $3 "$.

Foot Candle

A measure of light striking a surface

Footer

The part of a foundation system that actually transfers the weight of the building to the ground

Frost Line

The maximum depth of the soil where water will freeze during the coldest weather

Furnace

An appliance for heating a medium to distribute heat throughout the dwelling unit.

\section{G}

Gable

The triangular section of an end wall formed by the pitch of the roof.

Gas Heating System

A heating system that uses natural gas or bottled liquid propane gas as fuel.

Gasket

Elastic strip that seals a joint between two materials.

Glazing

Glass installation. Pertaining to glass assemblies or windows 
Glass Load Factor

A number combining glass's solar heat transmission and its heat conduction. Used for cooling load calculations.

Gravity Furnace

A central heating system that uses natural gravity to distribute heat throughout the dwelling unit as opposed to forced circulation, pumps, or circulation blowers.

Gusset

A metal or wood plate added to the surface of a joint to strengthen the connection.

Gypsum Board

A common interior sheeting material for walls and ceilings made of gypsum rock powder packaged between two sheets of heavy building paper. Also called sheetrock, gyprock, or gypboard.

\section{$\mathbf{H}$}

Handicapped Person

Any individual who is: 1) handicapped as defined in Section 7 (6) of the Rehabilitation Act of 1973; 2) under a disability as defined in Section 1614 (1) (3) (A) or 223 (d) (i) of the Developmental Disabilities Services and Facilities Construction Act; or 3) who is receiving benefits under Chapter 11 or 15 of Title 38, U.S.C. Other conditions may apply state to state, which can deem an individual as handicapped for the purposes of the WAP.

HDD - Heating Degree Day(s)

The number of degrees per day that the daily average temperature (the mean of the maximum and minimum recorded temperatures) is below a base temperature, usually 65 degrees Fahrenheit, unless otherwise specified; used to determine indoor space heating requirements and heating system sizing. Total HDD is the cumulative total for the year/heating season. The higher the HDD for a location, the colder the daily average temperature(s).

Heat Anticipator

A very small electric heater in a thermostat that causes the thermostat to turn off before room temperature reaches the thermostat setting, so that the house does not overheat from heat remaining in the furnace and ducts after the burner shuts off.

Heat Capacity

The quantity of heat required to raise the temperature of 1 cubic foot of a material 1 degree $F$.

Heat Gains

Term used to mean unwanted heat that accumulates in homes, making mechanical cooling desirable or necessary. 
Heat Loss

The amount of heat escaping through the building shell as

measured for a specific period of time (month, year, etc.)

Heat Rise

The number of degrees of temperature increase that air is heated as it is blown over the heat exchanger. Heat Rise equals supply temperature minus return temperature.

Heat Transmission

Heat flow through the walls, floor, and ceiling of a building, not including air leakage.

Heat Transfer Coefficient

See U-value.

Heated Floor Area

The heated floor area is the floor area, in square feet, of all conditioned space.

\section{Heating Degree Day}

Each degree that the average daily temperature is below the base temperature (usually 65 degrees $F$ ) constitutes one heating degree day.

Heating Load

The maximum rate of heat conversion needed by a building during the very coldest weather.

Heating Seasonal Performance Factor (HSPF)

Rating for heat pumps describing how many Btus they transfer per kilowatt-hour of electricity consumed.

\section{HERS}

Home Energy Rating Systems

A nationally recognized energy rating program that give builders, mortgage lenders, secondary lending markets, homeowners, sellers, and buyers a precise evaluation of energy losing deficiencies in homes. Builders can use this system to gauge the energy quality in their home and also to have a star rating on their home to compare to other similarly built homes.

\section{High Limit}

A bimetal thermostat that turns the heating element of a furnace off if it senses a dangerously high temperature.

Home Heating Index

The number of Btus of energy used by a home divided by its area in square feet, then divided by the number of heating degree days during the time period. 
HOME Program

A program created under Title II (the Home Investment Partnership Act) of the National Affordable Housing Act of 1990. Provides funds for states to expand the supply of decent and affordable housing for low-income people. This program can be easily coordinated with a state's WAP efforts.

Household

Any individual or group of individuals who are living together as one economic unit for whom residential energy is customarily purchased in common or who make undesignated payments for energy in the form of rent.

House Pressure

The difference in pressure between the indoors and outdoors measured by a manometer.

HUD

U.S. Department of Urban Housing and Development

Humidistat

An automatic control that switches a fan, humidifier, or dehumidifier on and off to control relative humidity.

Humidity Ratio

Same as "absolute humidity." The absolute amount of air's humidity measured in pounds of water vapor per pound of dry air.

HVAC

Heating, Ventilation, and Air-Conditioning System

All components of the appliances used to condition interior air of a building.

Hydronic

A heating system that uses hot water or steam as the heattransfer fluid.

\section{I}

IAQ - Indoor Air Quality

The quality of indoor air relative to its acceptability for healthful human habitation. Assessing and ameliorating, when necessary, the quality of indoor air is a major concern of the weatherization process. In particular, all by-products of major combustion appliances must be directly evacuated to the outdoors under all operating conditions.

Illumination

The light level measured on a horizontal plane in Foot Candles 
Inch of Water

Small air pressure differences caused by wind, blower doors, furnace fans, and chimneys are measured in inches of water (in.$\mathrm{H} 2 \mathrm{O}$ ) in the American measurement system.

Incidental Repairs

Under DOE rules, this term refers to the repairs on a dwelling unit necessary for the effective performance or preservation of the allowable energy conservation measures to be installed. Usually, a specific dollar amount is set by a state to limit such incidental repairs.

Indoor Air Quality (IAQ)

Refers to the measurement of air quality in the living space of the home. Pollutants can exist within a home, and WAP staff must be aware of the impact their work has on the quality of the atmosphere within the living space. The presence of pollutants, combined with inadequate ventilation factors, can contribute to a variety of occupant health and safety problems. Therefore, IAQ is a primary concern when workers seal or "tighten" homes.

In-Kind Contributions

In-kind contributions represent the value of non-cash contributions provided by the grantee, and non-Federal parties. In-kind contributions may be in the form of charges for real property and non-expendable personal property and the value of goods and services directly benefiting and specifically identifiable to the project or program.

Infiltration

Infiltration refers to the movement of air into a building through cracks and penetrations in the building envelope. Cold air often enters the structure due to depressurization, exfiltration, wind, stack effect, and/or convective airflow.

Infrared Thermography

The science of using infrared imaging to detect radiant energy or heat loss characteristics of a building. The infrared camera or scanner electronically senses heat radiated by objects and converts that thermal energy into images visible to the human eye. The camera or scanner, similar to a camcorder in appearance, produces varying shades of black and white images of the building structure. The darker the image, the colder the corresponding surface; the lighter areas are the hotter surfaces. Some scanners can automatically record these images on video, as well as allow the operator to record audio commentary as he/she scans the building. A certain degree of interpretation skill is required to properly assess the images being recorded. Used in conjunction with a blower door, the scanner can provide valuable data, since the pressurization or depressurization can magnify air leakage sites and thermal bypasses. 
Input Rating

The measured and assigned rating indicating the level at which an energy-using device consumes electricity or fossil fuel.

Insolation

The amount of solar radiation striking a surface

Insulated Glass

Two or more glass panes installed in windows and doors, spaced apart and sealed in a factory.

Internal Gains

The heat generated by bathing, cooking, and operating appliances, that must be removed during the summer to promote comfort.

Intermittent Ignition Device

A device that lights the pilot on a gas appliance when the control system calls for heat, thus saving the energy wasted by a standing pilot.

Intermediate Zone

A zone located between the building's conditioned space and the outdoors, like a crawl space or attic.

\section{$\mathbf{J}$}

Jamb

The side or top piece of a window or door frame.

Joist

A horizontal wood framing member that supports a floor or ceiling.

\section{$\mathbf{K}$}

Kilowatt

A unit of electric power equal to 1000 joules per second or 3412

Btus per hour.

Kilowatt-hour

A unit of electric energy equal to 3600 kilojoules.

$\mathrm{L}$

Landlord/Tenant Agreement

Document required for completed application when applicant is a renter. The Agreement is legally binding contract, signed by the tenant, the landlord (or property owner), and the local agency specifying the role and responsibilities of each party. The basic goal of the WAP is to ensure that the benefits of the program accrue to the low-income family. A variety of standard clauses can 
be incorporated into the Agreement, including clauses on landlord's inability to raise rents for specified period of time, eviction prohibition, and landlord required "participation."

Participation can take the form of actual cash, provided labor, and/or in-kind contributions.

Leakage Ratio

Measurement of total square inches of infiltration area per 100

feet of building envelope surface area.

Leverage Activity

The actions of the state and local agencies to obtain and account for resources provided to supplement or supplant federal funding being used to weatherize dwelling units.

Linear Measure

A system of measurement in length; also called long measure.

Local Agency

Also referred to as the subgrantee, contractor, service delivery network member, or local service provider, a local agency is a nonprofit organization or unit of local government responsible for providing WAP services in a specified political subdivision.

\section{Low-E}

Short for "low emissivity", which means the characteristic of a metallic glass coating to resist the flow of radiant heat.

Low Water Cutoff

A float-operated control for turning the burner off if a steam boiler is low on water.

Lumen

A unit of light output from a lamp.

\section{$\mathbf{M}$}

Make-up Air

Air supplied to a space to replace exhausted air.

Manometer

Measuring device for small gas pressures.

Mastic

A thick creamy substance used to seal seams and cracks in building materials.

MHEA

Mobile Home Energy Audit

A software tool that predicts manufactured home energy

consumption and recommends weatherization retrofit measures. 
Mitigate

To make less severe or to mollify.

Mortar

A mixture of sand, water, and cement used to bond bricks, stones, or blocks together.

Mortise

A recessed area cut into the wood framing member where a hinge or wood tongue fits.

\section{$\mathbf{N}$}

\section{NASCSP}

National Association for State Community Services Programs NASCSP's mission is to assist state in responding to poverty issues. NASCSP members are state administrators of the Community Services Block Grant (CSBG) and U.S. Department of Energy's Weatherization Assistance Program (DOE/WAP). The CSBG, administered by the states, provides core funding to local agencies to reduce poverty, revitalize low-income communities and to empower low-income families to become self-sufficient. The DOE/WAP helps low-income families reduce their energy costs by making homes more energy efficient. The local agencies funded by these programs provide a wide range of services such as weatherization, energy assistance, child care, job training, and housing. NASCSP keeps its members, the federal government, and other interested parties informed about issues related to CSBG and DOE/WAP through its publications.

Natural Ventilation

Ventilation using only natural air movement without fans or other mechanical devices.

\section{NEAT}

National Energy Audit Created by Oak Ridge National Laboratories as a DOE approved audit qualifying for the $40 \%$ materials waiver. It is a computerized auditing tool for prioritizing energy conservation measures for houses.

Net Free Area

The area of a vent after that area has been adjusted for insect screen, louvers, and weather covering. The free area is always less than the actual area.

Nozzle

An orifice for spraying a liquid like fuel oil. 


\section{$\mathbf{O}$}

Oil Heating System

Refers to a central heating system that uses \#2 fuel oil, kerosene, or residual oil as the primary fuel for heat generation.

Open-Combustion Heater

A heating device that takes its combustion air from the surrounding room air.

\section{Orifice}

A hole in a gas pipe or nozzle fitting where gas or fuel oil exits to be mixed with air before combustion occurs in the heating chamber.

Oscillating Fan

A fan, usually portable, that moves back and forth as it operates, changing the direction of the air movement.

Output Capacity

The conversion rate of useful heat that a heating unit produces after accounting for any waste caused by the conversion of energy into heat.

Oxygen Depletion Sensor

A safety device on a heating unit that shuts off the fuel supply to the combustion chamber when oxygen is depleted.

\section{$\mathbf{P}$}

Packaged Air Conditioner

An air conditioner that contains the compressor, evaporator, and condenser in a single cabinet.

\section{PA - Pascal}

A unit of measurement of air pressure. One column inch of water equals 247 pascals. Atmospheric pressure (29.92 inches of mercury) is equivalent to $102,000 \mathrm{PA}$.

\section{Payback Period}

The number of years that an investment in energy conservation will take to repay its cost through energy savings.

Perlite

A heat-expanded mineral used for insulation.

\section{Perm}

A measurement of how much water vapor a material will let pass through it per unit of time. 
Plaster

A plastic mixture of sand, lime, and Portland cement spread over wood or metal lath to form the interior surfaces of walls and ceilings.

Plate

A piece of lumber installed horizontally to which the vertical studs in a wall frame are attached.

Platform Framing

A type of framing where the first- and second-floor studs are separate pieces of wood. The first=floor studs have a plate on top of them upon which the second-floor joists rest.

\section{Plenum}

The piece of ductwork, usually found above the heat exchanger of a hot air furnace, that connects the air handler to the main supply duct.

Plumb

Absolutely vertical at a right angle to the earth's surface.

Plywood

Laminated wood sheeting with layers cross-grained to each other.

Polyethylene

Polymer plastic used for vapor barriers, air barriers, and foam backer rod.

Polyisocyanurate

A plastic foam insulation sold in sheets, similar in composition to polyurethane.

Polystyrene Insulation

A rigid plastic foam insulation, usually white or blue in color.

Polyurethane

A versatile plastic foam insulation, usually yellow in color.

Potential Energy

Energy in a stored or packaged form, like fuel oil, coal, wood, etc.

Pressure

A force encouraging movement by virtue of a difference in some condition between two areas.

Pressure Diagnostics

The practice of measuring pressures and flows in buildings to control air leakage, and also to ensure adequate heating and cooling air flows and ventilation. 
Pressure Pan

A device used to block a duct register while measuring the static pressure behind it.

Pressuretrol

A control that turns a steam boiler's burner on and off as steam pressure changes.

Prime Window

The main window installed on the outside wall consisting of fixed or moveable lights that slide on permanently fixed tracks (not to be confused with a storm window).

Priority List

The list or ranking of installation measures developed by a program to produce the most cost effective energy savings results based on a savings to investment ratio calculation.

Program Income

Income earned by the grantee from grant-supported activities, including but not limited to, income from service fees, sale of commodities, usage or rental fees, and royalties on patents and copyrights.

Psychrometrics

The study of the relationship between air, water vapor, and heat.

Purlins

Framing members that sit on top of rafters, perpendicular to them, designed to spread support to roofing materials.

PV

Photovoltaic

A solid-state elctrical device that converts light directly into direct current electricity of voltage-current characteristics that are a function of the characteristics of the light source and the materials in and design of the device. Solar photovoltaic devices are made of various semi-conductor materials including silicon, cadmium sulfide, cadmium telluride, and gallium arsenide, and in single crystalline, multi-crystalline, or amorphous forms.

\section{$\mathbf{R}$}

R-Value

A measurement of thermal resistance for materials and related surfaces.

Radiant Barrier

A foil sheet or coating designed to reflect heat producing sun rays. 
Radiant Temperature

The average reflective temperature of objects in a home, like walls, ceiling, floor, and furniture.

Radiation

Heat energy originating on a hot body like the sun and traveling from place to place through the air.

Radon

A radioactive gas that decomposes into radioactive particles.

Rafter

A roof beam that follows the roof's slope.

Reflectance

Also called reflectivity, it is the ability of a material's surface to reflect radiant heat.

Recovery Efficiency

A water heater's efficiency at actually heating water to capacity level without regard to standby or distribution losses.

Reflective Glass

Glass that has a mirror-like coating on its exterior surface to reflect solar heat. The solar heat gain coefficient of reflective glass ranges from 0.10 to 0.40 .

\section{Refrigerant}

A special fluid used in air conditioners and heat pumps that heats air when it condenses from a gas to a liquid and cools air when it evaporates from a liquid to a gas.

Register

The grille cover over a duct outlet for warm air distribution or cold air return.

Relamping

The replacement of an existing, standard light bulbs with lower wattage energy efficient bulbs like compact fluorescent lamps.

Relative Humidity

The percent of moisture absorbed in the air compared to the maximum amount possible. For instance, air that is completely saturated has $100 \%$ relative humidity.

Relay

An automatic, electrically-operated switch.

Reset Controller

Adjusts fluid temperature or pressure in a central heating system according to outdoor air temperature. 


\section{Resistance}

The property of a material resisting the flow of electrical energy or heat energy.

\section{Retrofit}

An energy conservation measure applied to an existing building or the action of improving the thermal performance or maintenance of a building.

\section{Return Air}

Air circulation back to the furnace from the house to be heated by the furnace and supplied to the rooms.

Re-Weatherized Unit

Any unit that received weatherization services prior to September 30, 1985 and has received additional services under subsequent grants or allowed by current DOE regulations.

Rim Joist

The outermost joist around the perimeter of the floor framing.

\section{S}

Savings-to-Investment Ratio (SIR)

They are computed over the lifetimes of the retrofit measures installed and expressed in terms of the net present value of the retail cost of the dwelling's fuel. Under some methodologies, other benefits, etc. Investment usually takes into account materials, labor, and support costs. SIRs of greater than one are counted as cost effective under this DOE WAP method of determining costeffectiveness.

Sealed Combustion Heater

A heater that draws air for combustion from outdoors and has a sealed exhaust system.

\section{Seasonal Efficiency}

Refers to the overall efficiency of the central heating system including on and off cycle fuel utilization and heat loss. The calculation of these factors is represented in the Annual Fuel Utilization Efficiency (AFUE) rating for the appliance. Distribution system loss is not factored into the AFUE.

\section{Seasonal Energy Efficiency Ratio (SEER)}

A measure of seasonal or annual efficiency of a central air conditioner or air conditioning heat pump. It takes into account the variations in temperature that can occur within a season and is the average number of Btu of cooling delivered for every watthour of electricity used by the heat pump over a cooling season. 
Seasonal Performance Factor (SPF)

Ratio of useful energy output of a device to the energy input, averaged over an entire heating season.

Separate Living Quarters

Living quarters in which the occupants do not live and eat with any other persons in the structure and that have either a direct access from the outside of the building or through a common hall or complete kitchen facilities for the exclusive use of the occupants. The occupants maybe a single family, one person living alone, two or more families living together, or any other group of related or unrelated persons who share living arrangements.

Sequencer

A bimetal switch that turns on the elements of an electric furnace in sequence.

Settling

This term refers to the effect of insulation depressing over time and, thereby, reducing the overall energy efficiency of the materials. This process is primarily the result of using too much air when installing the blown-in insulation - commonly called "fluffing," or the effect of long periods of time on the materials. One reason to re-inspect some work several months after installation to assess the settling factor. Settling can also occur during the installation of sidewall insulation when the cavity is not completely filled. This is usually avoided if "dense pack" protocols are followed during the installation.

Shading Coefficient (SC)

A decimal describing how much solar energy is transmitted through a window opening compared to clear single glass having an SC of 1.0. For example, reflective glass has an SC of .20 to .45.

Sheathing

A structural sheeting, attached on top of the framing, underneath siding, or on the roof of a building.

Sheeting

Common term for any building material used for covering a building surface.

Shell

The building's exterior envelope including walls, floor, and roof.

Shingle

A modular roofing material, usually asphalt, that is installed in overlapping rows to cover the entire roof. 


\section{Short Circuit}

A dangerous malfunction in an electrical circuit where electricity is flowing through conductors and into the ground without going through an electric load, like a light or motor.

\section{Sidewall Insulation}

The process of installing insulation material, usually blown cellulose, into the non-insulated wall stud cavities of a structure to reduce heat loss. Installation is achieved by drilling one or more rows of holes into the wall, one in each stud cavity. To achieve the most effective results, a dense pack protocol is used to install "high density" insulation materials. The "packing" of the materials should be tight enough that the installer cannot move the insulation when complete. It is common to install materials at 3.5 pounds per square foot.

Sill

The bottom of a window or door frame.

\section{Sill Box}

The outer area of the floor bound by the rim joist, floor joist, sill plate, and floor.

Sling Psychrometer

A device holding two thermometers that is slung through the air to measure relative humidity.

\section{Soffit}

The underside of a roof overhang or a small lowered ceiling, as above cabinets or a bathtub.

\section{Solar Gain}

Heat from the sun that is absorbed by a building's materials and contributes to the heating and cooling requirements of the dwelling.

\section{Solar Heat}

Radiant energy from the sun with wavelengths between 0.7 and 1 micrometers.

\section{Solar Heat Gain Coefficient (SHGC)}

The ratio of solar heat gain through a window to incident solar heat, including both transmitted heat and absorbed/radiated heat.

\section{Solar Heat Gain Factor (SHGF)}

Solar heat gain amount on a surface with a particular angle and orientation expressed in Btus per square foot per hour.

Solar Transmittance

The percent of total solar energy transmitted by a material. 
Solenoid

A magnetic device that moves a switch or valve stem.

Space Heating

Heating the living spaces of the home with a room heater or central heating system.

Span

Horizontal distance between supports.

Specific Heat

The ratio of the heat storage capacity of a particular material to the heat storage capacity of water.

Spillage

Temporary flow of combustion gases from a dilution device.

Spline

A strip of vinyl, rubber, or plastic that, when inserted into a groove, holds a screen or plastic film in place on a frame.

Split-System Air Conditioner

An air conditioner having the condenser and compressor outdoors and the evaporator indoors.

Stack Effect

The term describes the effect of higher pressure at the top of a structure, lower pressure at the bottom of a structure, and neutral pressure somewhere in between, relative to the ambient (surrounding) air pressure. It is usually the result of different densities of warmer and cooler air (convective airflow).

Standing Loss

Heat loss from a hot water storage tank through its shell.

Steady State Efficiency

The measurement of heat system balance in the on-cycle when heat into system equals heat out. Generally provided as a percentage of the maximum available heat generation capacity $(100 \%)$ against the amount of usable heat being sent to the distribution system. This figure can also represent the percentage of heat being used within the system as compared to the heat lost through the flue. The reading is most valid when the stack temperature becomes constant and the distribution pumps or blowers are operating.

Steam Trap

An automatic valve that closes to trap steam in a radiator until it condenses. 
Steam Vent

A bimetal-operated air vent that allows air to leave steam piping and radiators, but closes when steam strikes the surface.

Stop

A thin, trim board for windows and doors to close against or slide against.

Strike Plate

The metal plate attached to the door jamb that the latch inserts into upon closing.

Stud

A vertical wood or metal framing member used to build a wall.

Sub-Floor

The sheathing over the floor joists and under the floor covering.

Supply Air

Air that has been heated or cooled and is moved through the ducts and to the supply registers of a home.

Suspended Ceiling

Modular ceiling panels supported by a hanging frame.

\section{$\mathbf{T}$}

Taped Duct Test (TDT)

A procedure using the blower door to measure the "potential" for leakage reduction of the duct system. All supply registers and return grills are taped shut following the initial blower door reading and a subsequent air leakage test taken. if closing off the duct system in this manner causes an appreciable reduction in the air leakage rate, this is an indication that there are significant duct leaks.

Therm

A unit of energy equal to 100,000 Btus or 29.3 kilowatt-hours.

Thermal Break

A relatively low heat/cold conductive material separating two highly conductive materials.

Thermal Bridging

Rapid heat conduction resulting from direct contact between very thermally conductive materials like metal and glass.

Thermal Bypass

Similar to a convection loop, this structural heat loss is characterized by heated air traveling up exterior or interior stud cavities and leaking out the top of that cavity to the attic through 
joints and cracks in the framing, wiring and plumbing holes, etc. These types of heat loss sources are sometimes the most difficult to locate.

Thermal Conductance

General term applied to both K-value and U-value, meaning heat flow rate.

Thermocouple

A bimetal-junction electric generator used to keep the safety valve of an automatic gas valve open.

Thermodynamics

The science of heat.

Title XVI

Term to be used interchangeably with those income groups known as SSI (Supplemental Security Income) recipients.

Tracer Gas

A harmless gas used to measure air leakage in a building.

Transformer

A double coil of wire that increases or decreases voltage from a primary circuit to a secondary circuit.

Trim

Decorative wood that covers cracks around window and door openings and at the corners where walls meet floors and ceilings. Sometimes called molding.

Truss

A lightweight, rigid framework designed to be stronger than a solid beam of the same weight.

\section{$\mathbf{U}$}

U-Value

The amount of heat flowing through a square foot of building materials.

\section{Ultraviolet Radiation}

Solar radiation having wavelengths just shorter than visible light.

Unconditioned Space

An area within the building envelope not intentionally or unintentionally heated. 
Vapor Barrier

A material that retards the passage of water vapor.

Vapor Diffusion

The flow of water vapor through a solid material.

Veiling Reflection

Light reflection from an object or task that obscures details.

Veneer

The outer layer of a building component (e.g., interior doors often have a wood veneer; some wood-frame houses have brick veneer walls, etc.).

Vent Connector

The vent pipe carrying combustion gases from the appliance to the chimney.

Vent Damper

An automatic damper powered by heat or electricity that closes the chimney while a heating device is off.

Venting

The removal of combustion gases by a chimney.

Ventilation

Refers to the controlled air exchange within a structure. All dwellings must "breathe" and proper ventilation rates must be determined. If the structure requires more interior/exterior air exchanges, there are mechanical and non-mechanical options for increasing those rates. The most common option is passive ventilation through the installation of roof, soffit, or gable vents.

Vermiculite

A heat-expanded mineral used for insulation.

Visible Transmittance

The percent of visible light transmitted by a glass assembly.

Visqueen

Polyethylene film vapor barrier.

\section{W}

Watt

A unit electrical power equivalent to one joule per second or 3.4 Btuh Watt-Hour

A unit of electrical energy equivalent to 3600 joules or 3.4 Btus. 
Weatherization Assistance Program (WAP)

DOE's Weatherization Assistance (Wx) Program is the nation's largest residential energy efficiency program. Its mission is to increase the energy efficiency of dwellings occupied by lowincome Americans, therby reducing their energy costs, while safeguarding their health and safety.

DOE works directly with the states, the District of Columbia, and Native American Tribal Governments to carry out these goals. These agencies, in turn, contract with approximately 1,000 local governmental or non-profit agencies to deliver weatherization services to our low-income clients.

Weatherstripping

Flexible gaskets, often mounted in rigid metal strips, for limiting air leak age at opening in the shell like doors and windows.

Webbing A reinforcing fabric used with mastics and coatings to prevent patches from cracking.

Weep Holes Holes drilled for the purpose of allowing water to drain out of an area in a building where it has accumulated.

Wet-Bulb Temperature

The temperature of a dampened thermometer of a Sling Psychrometer used to determine relative humidity, dew point, and enthalpy.

Window Films

Plastic films, coated with a metallic reflective surface, that are adhered to window glass to reflect heat rays from the sun.

Window Frame

The sides, top, and sill of the window forming a box around window sashes and other components.

Worst-Case Depressurization Test

A safety test, performed by specific procedures, designed to assess the probability of chimney back-drafting.

\section{$\mathbf{Z}$}

Zone

A room or portion of a building separated from other rooms by an air barrier. 


\section{Appendices 2}

Lecture Slides (Example) 


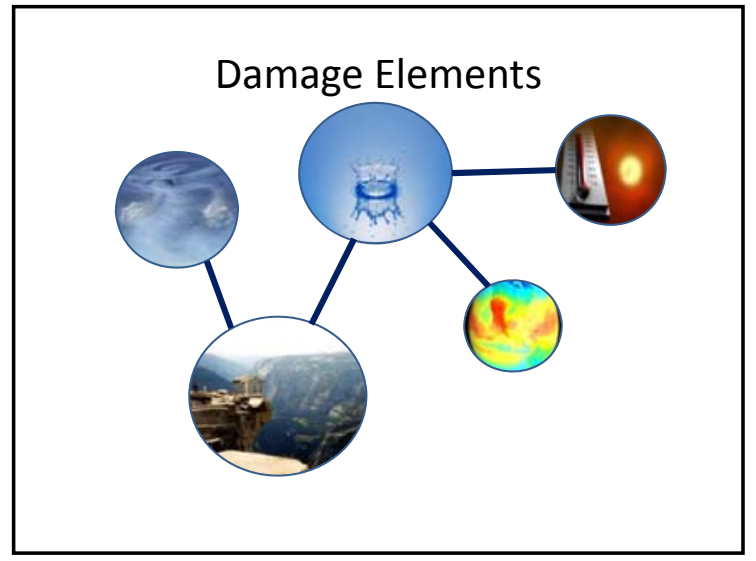

\section{Their Rules}

- Heat moves from warm to cold.

- Moisture moves from warm to cold.

- Moisture moves from more to less.

- Air out equals air in.

- Rain follows gravity.

- Most of it gets wet, how does it dry?

- It all happens at surfaces and connections.
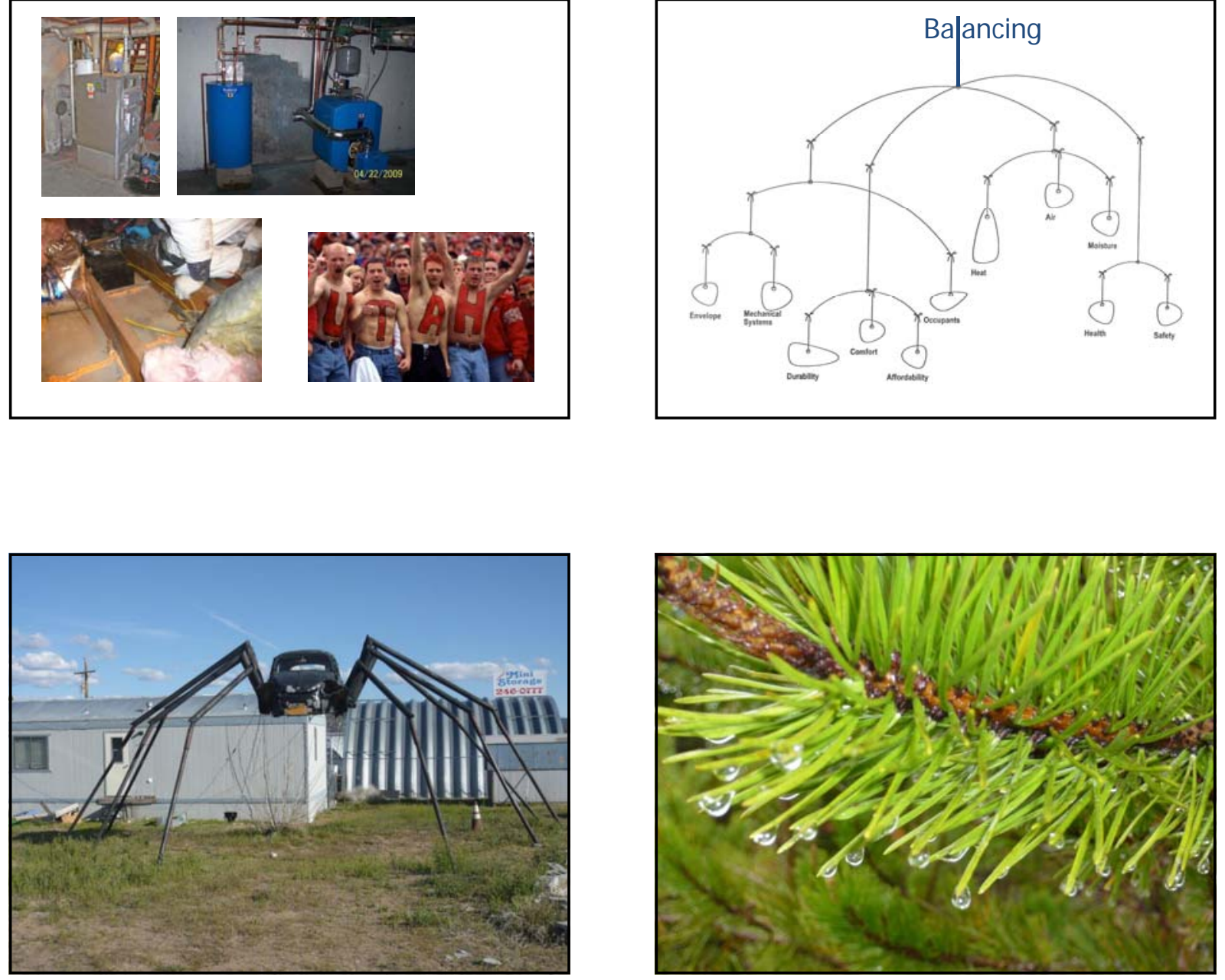

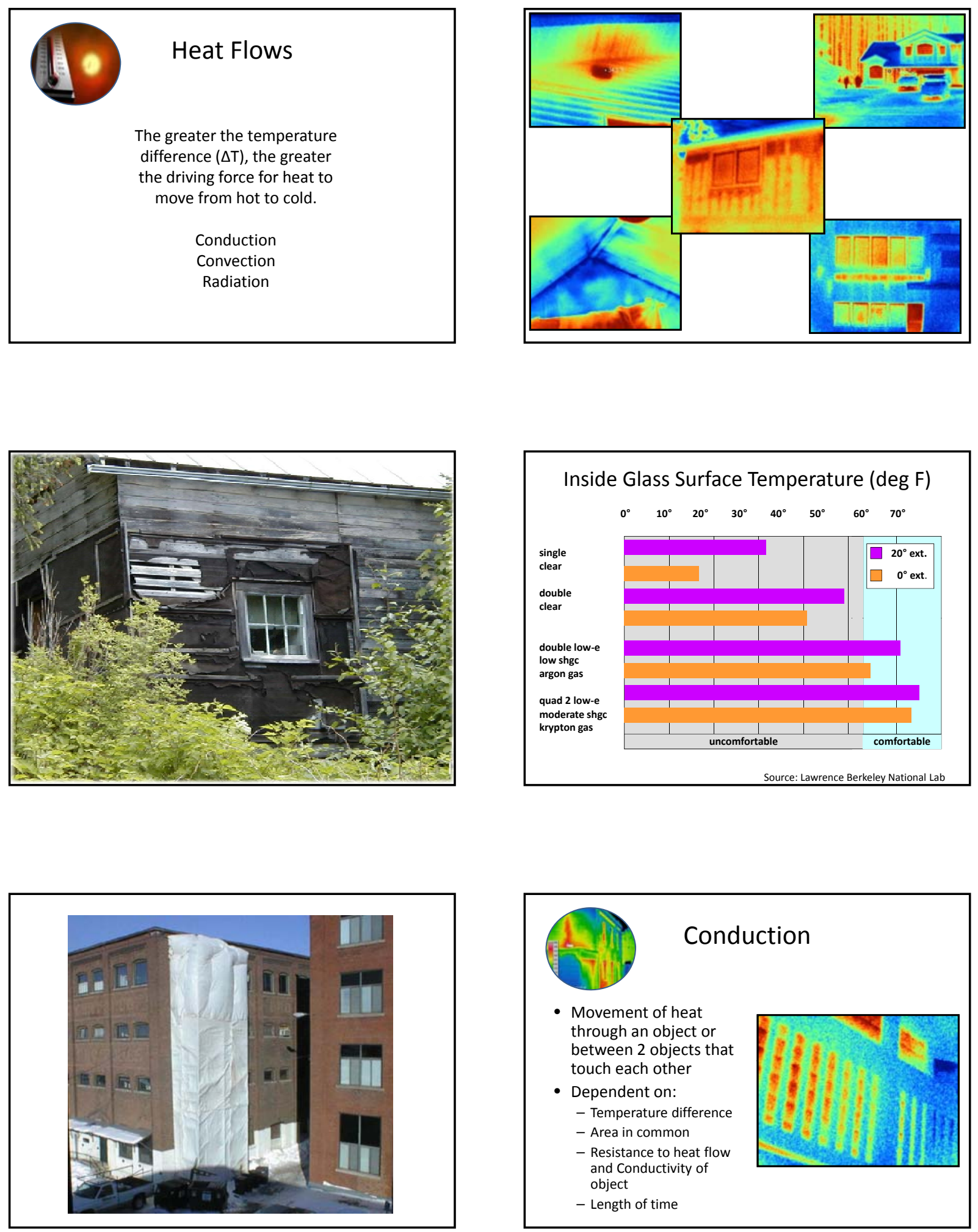

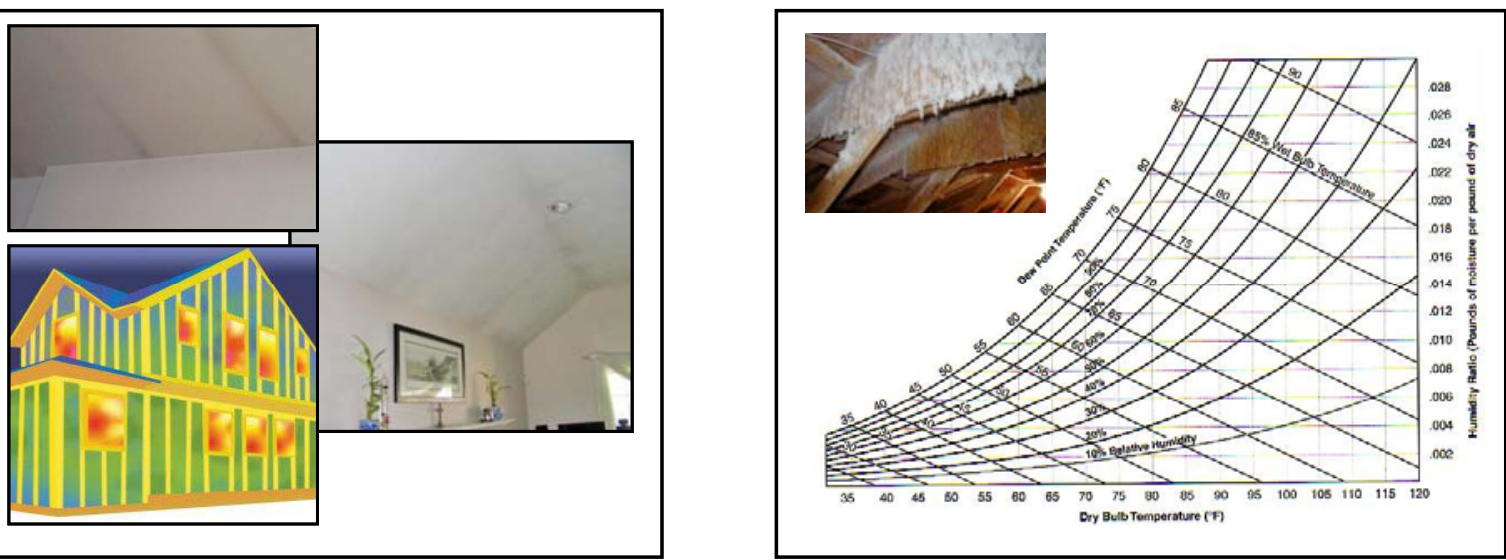

\section{Dewpoint Temperature}

- The temperature at which water vapor changes to liquid

- Dependent on temperature and amount of moisture in the air
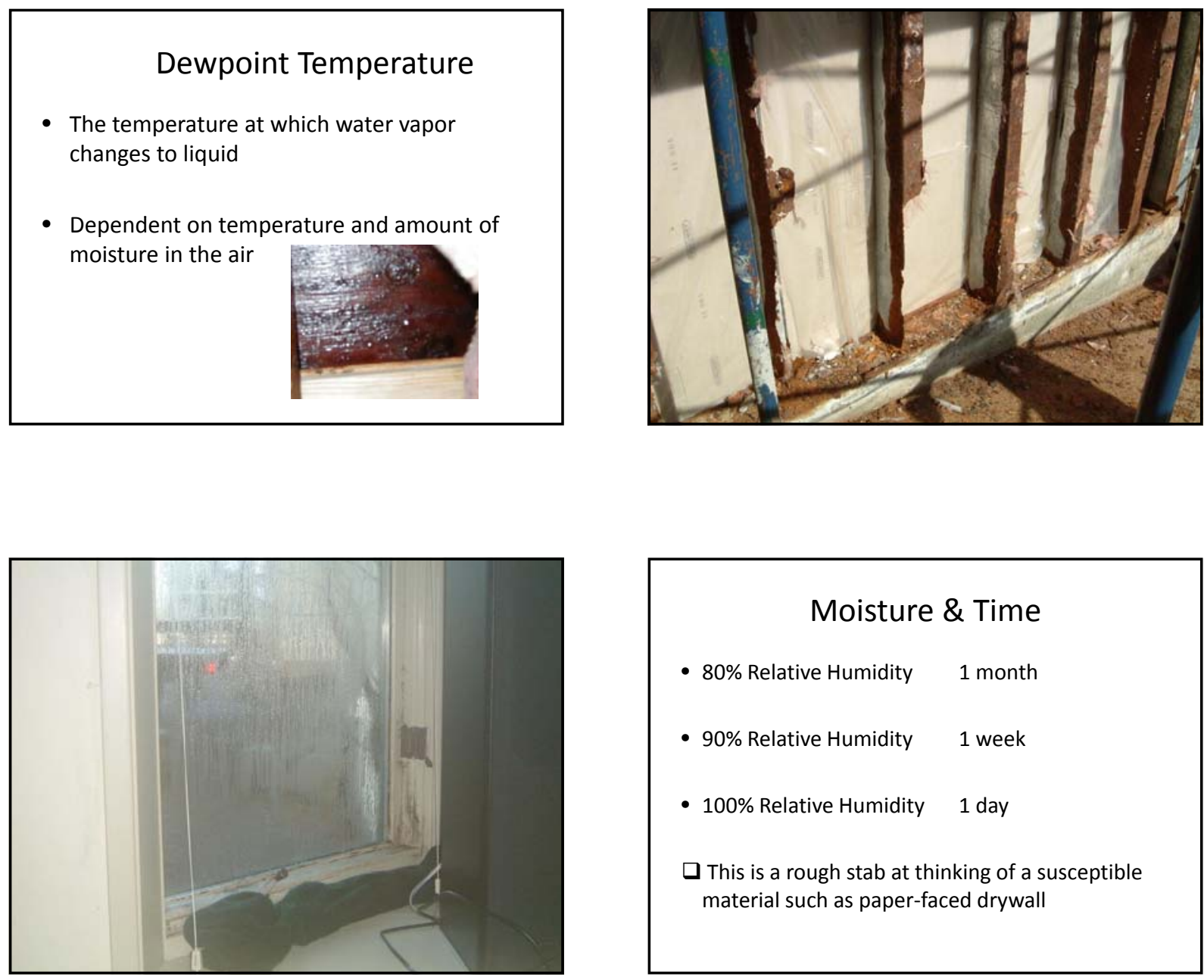

\section{Moisture \& Time}

- $80 \%$ Relative Humidity 1 month

- $90 \%$ Relative Humidity 1 week

- $100 \%$ Relative Humidity 1 day

This is a rough stab at thinking of a susceptible material such as paper-faced drywall 

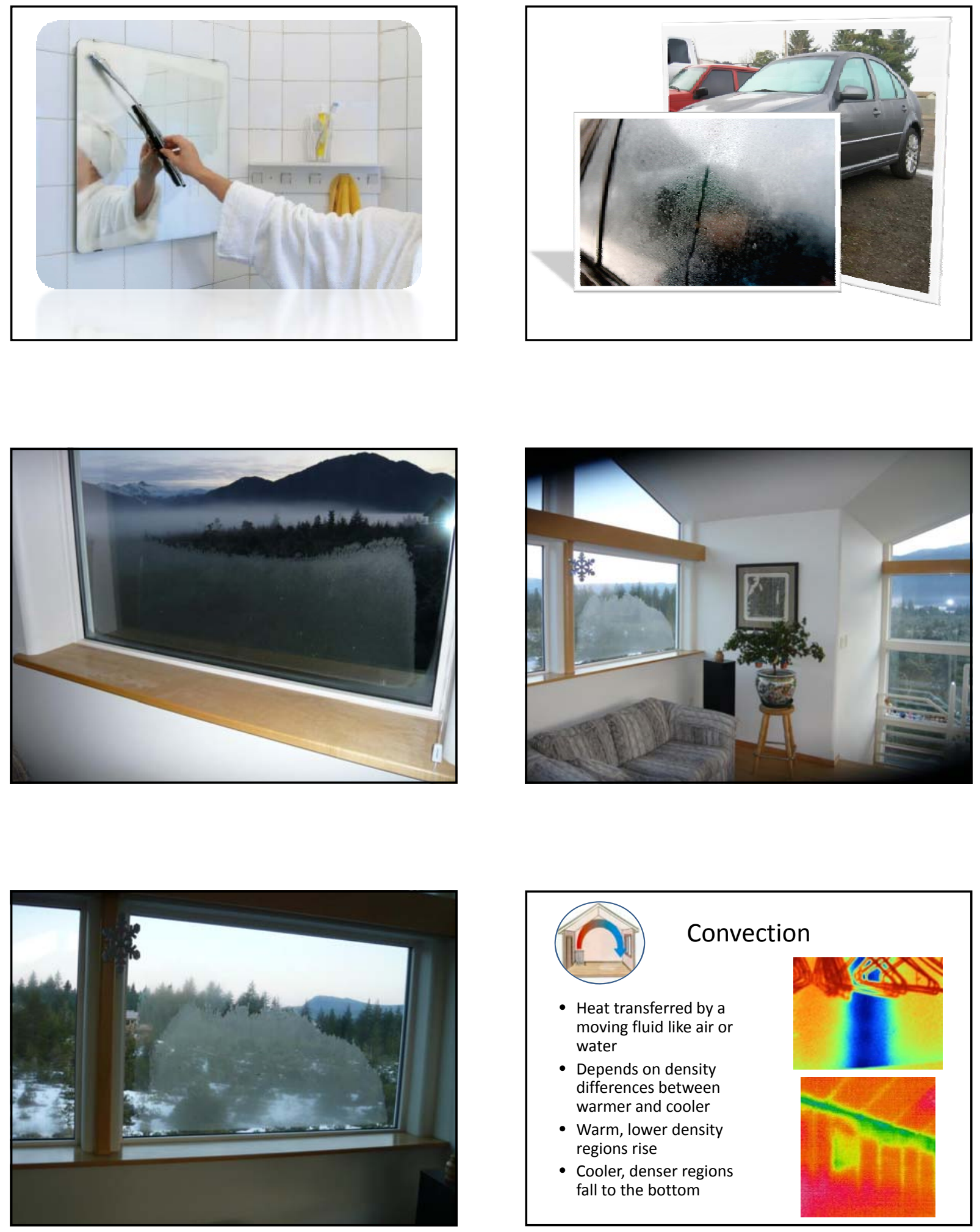

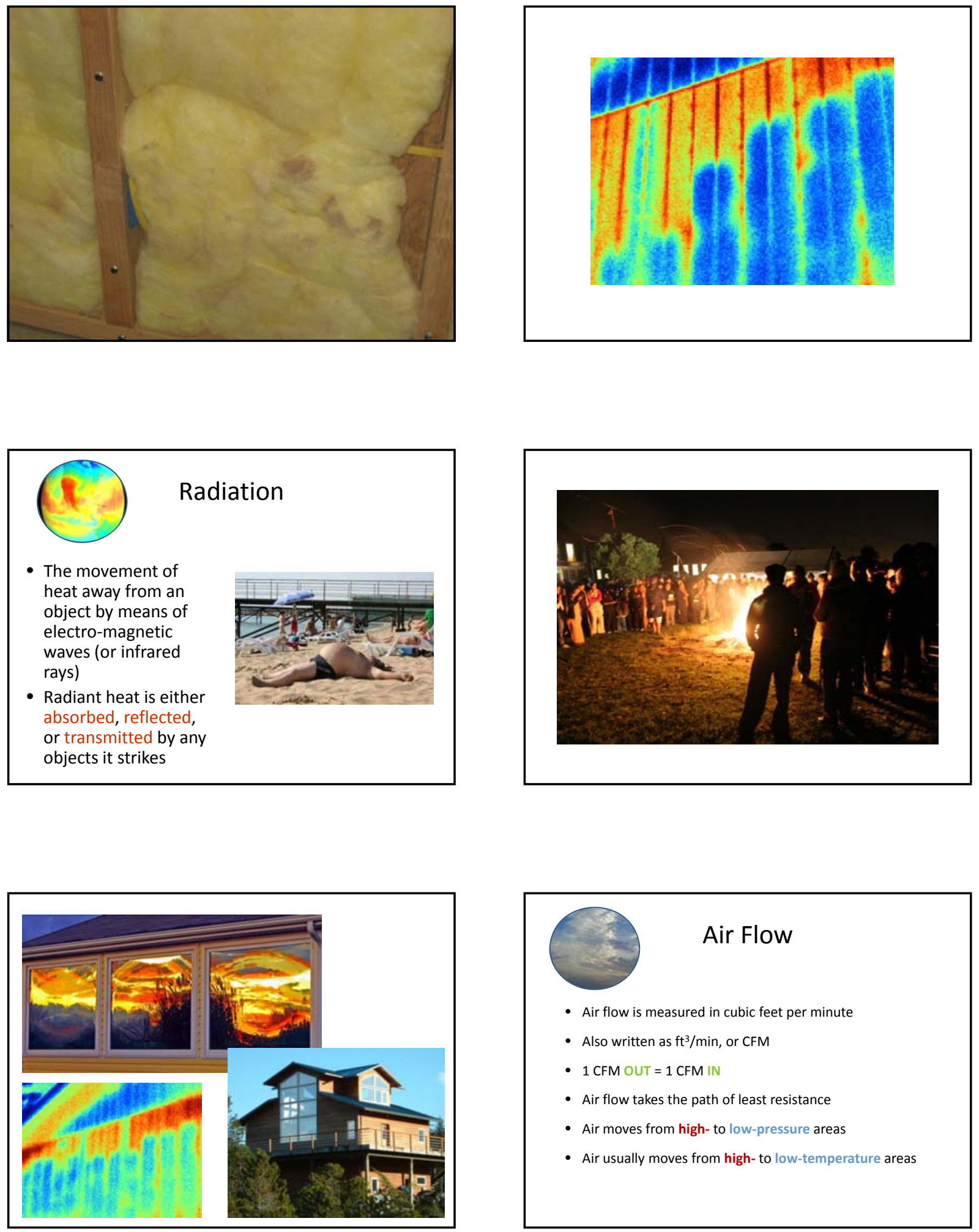

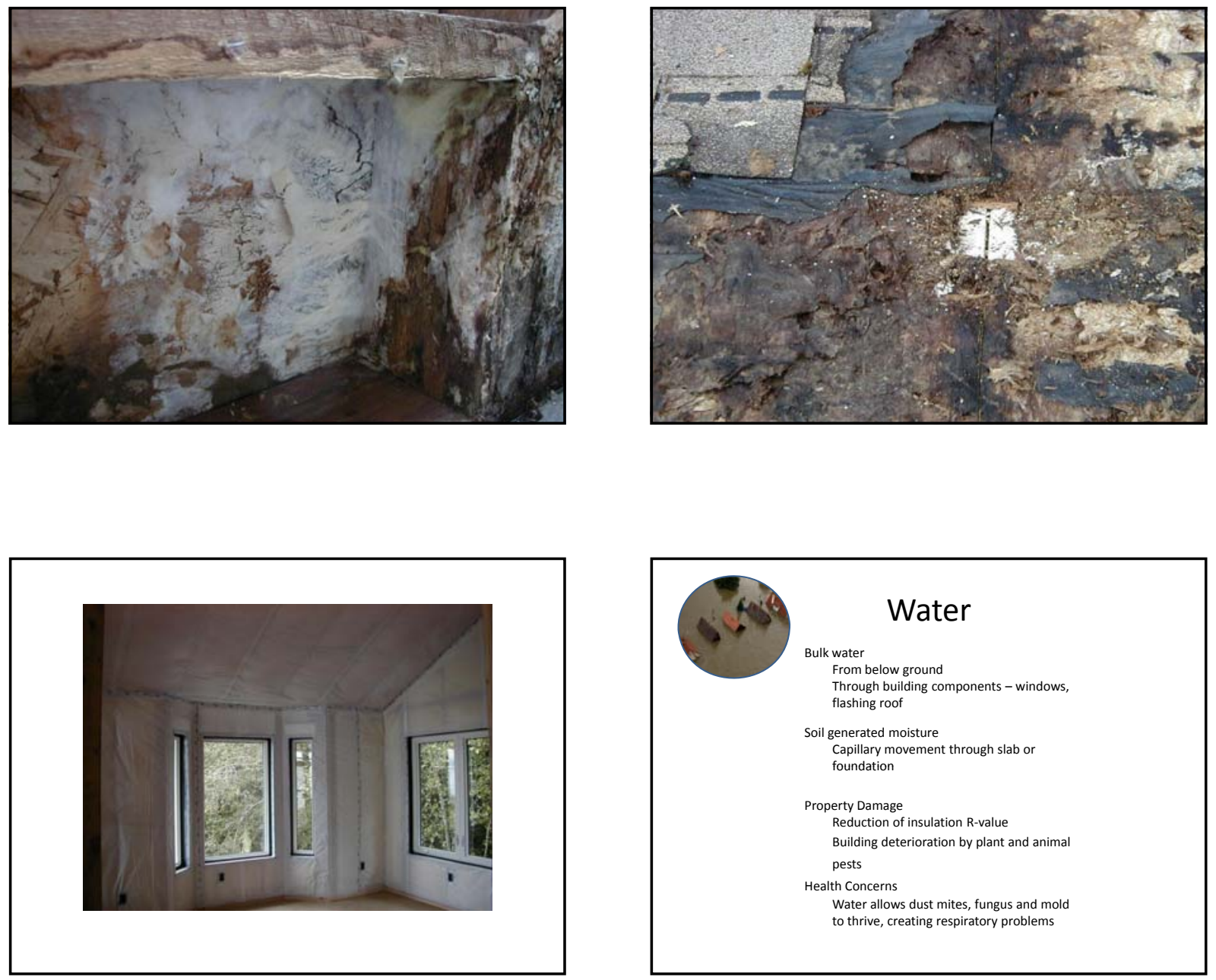

\section{Building Science: Moisture}

- Moisture wants to move from areas of high vapor pressure to areas of low vapor pressure

- When the home is being heated, moisture wants to move to the outside, and when it is being cooled moisture wants to move to the inside of the home.

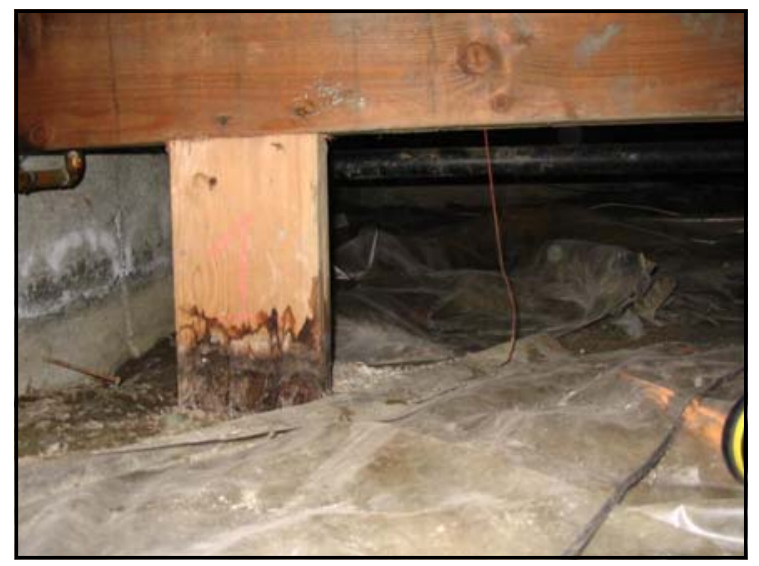



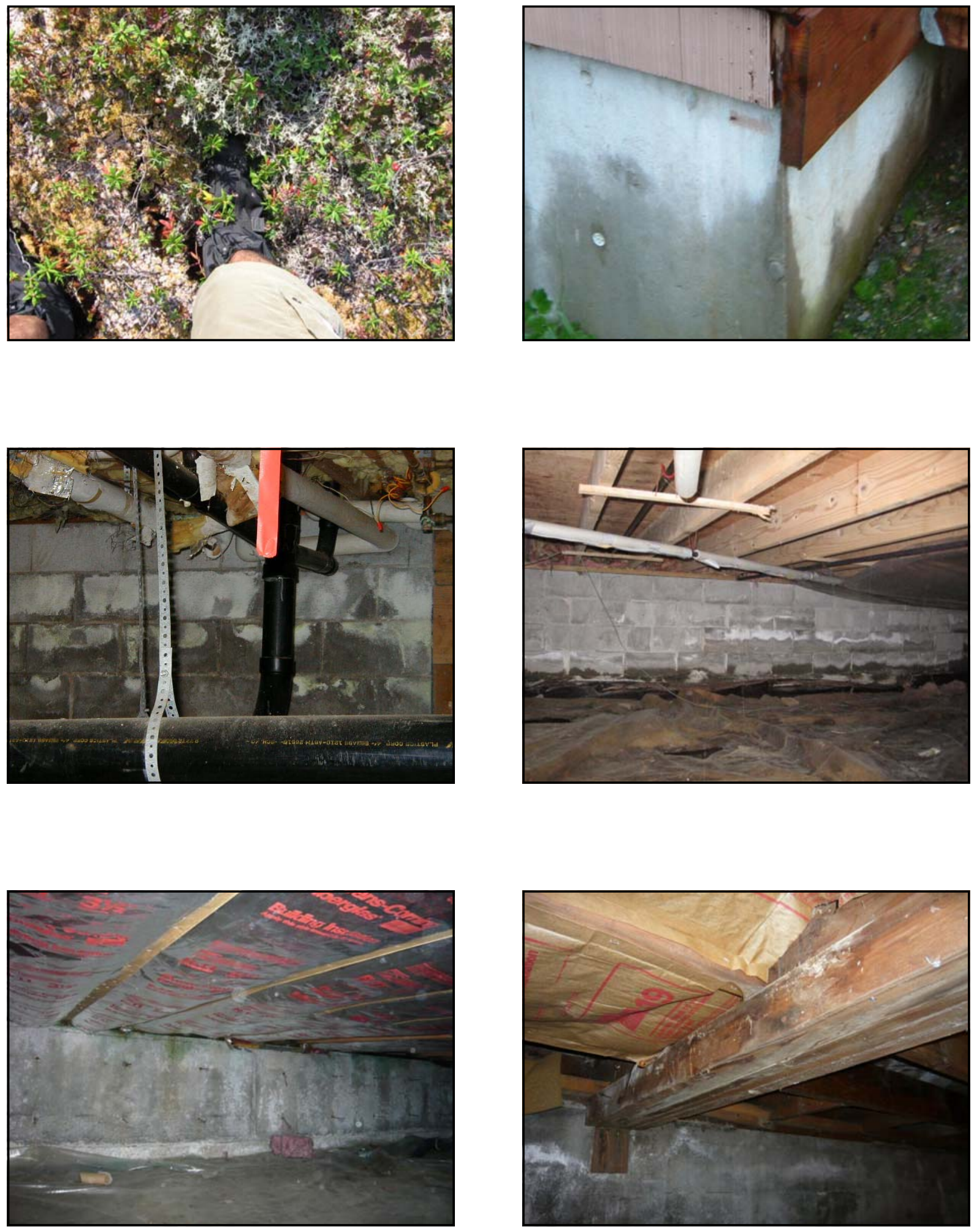

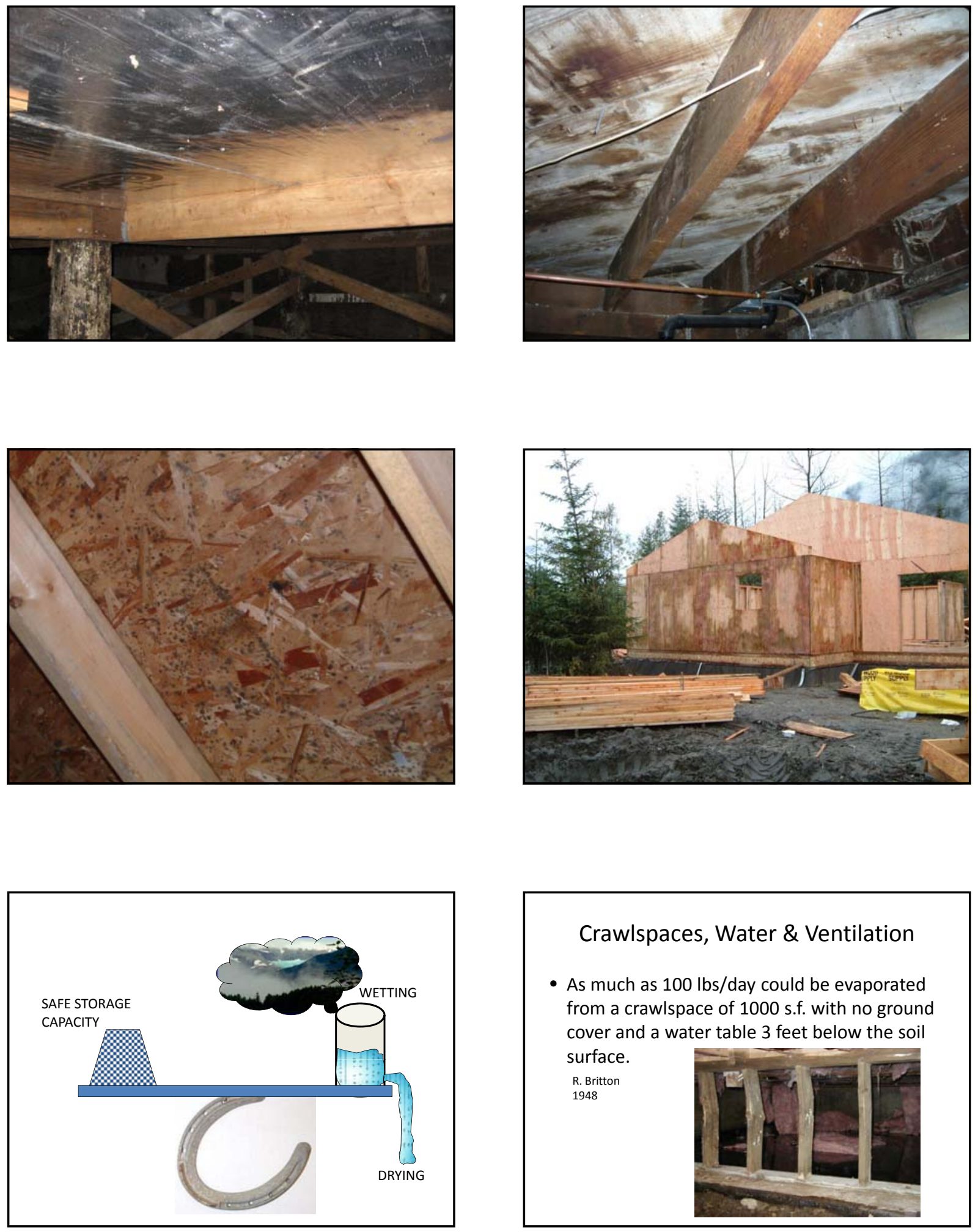

\section{Crawlspaces, Water \& Ventilation}

- As much as $100 \mathrm{lbs} /$ day could be evaporated from a crawlspace of 1000 s.f. with no ground cover and a water table 3 feet below the soil surface.

R. Britton

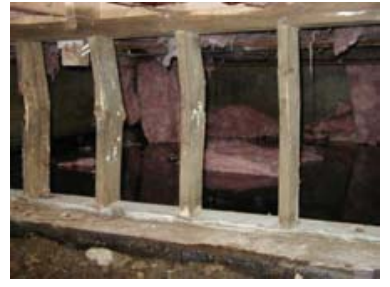



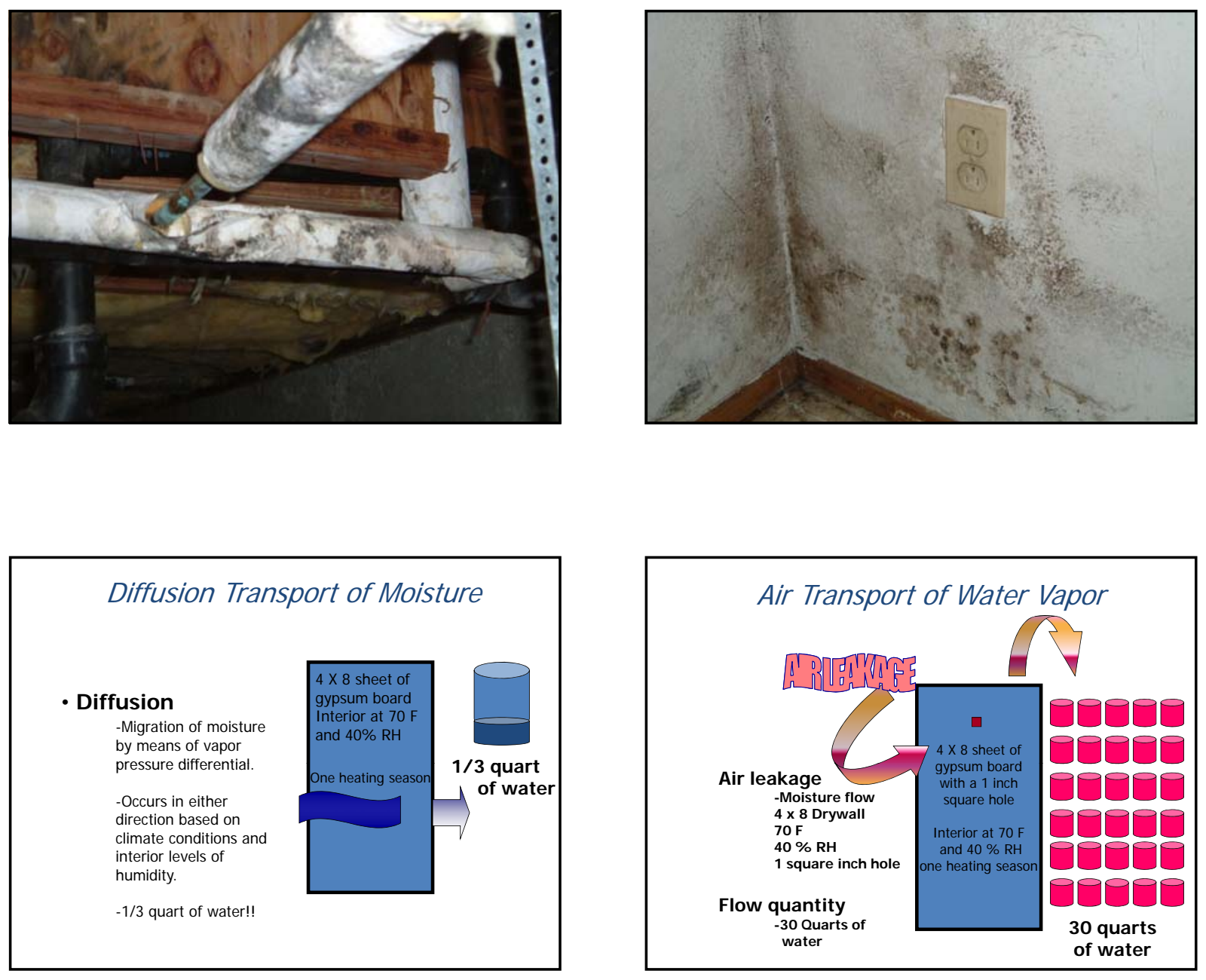

The drying potential of an assembly decreases with the level of insulation \& increases with the rate of air flow.
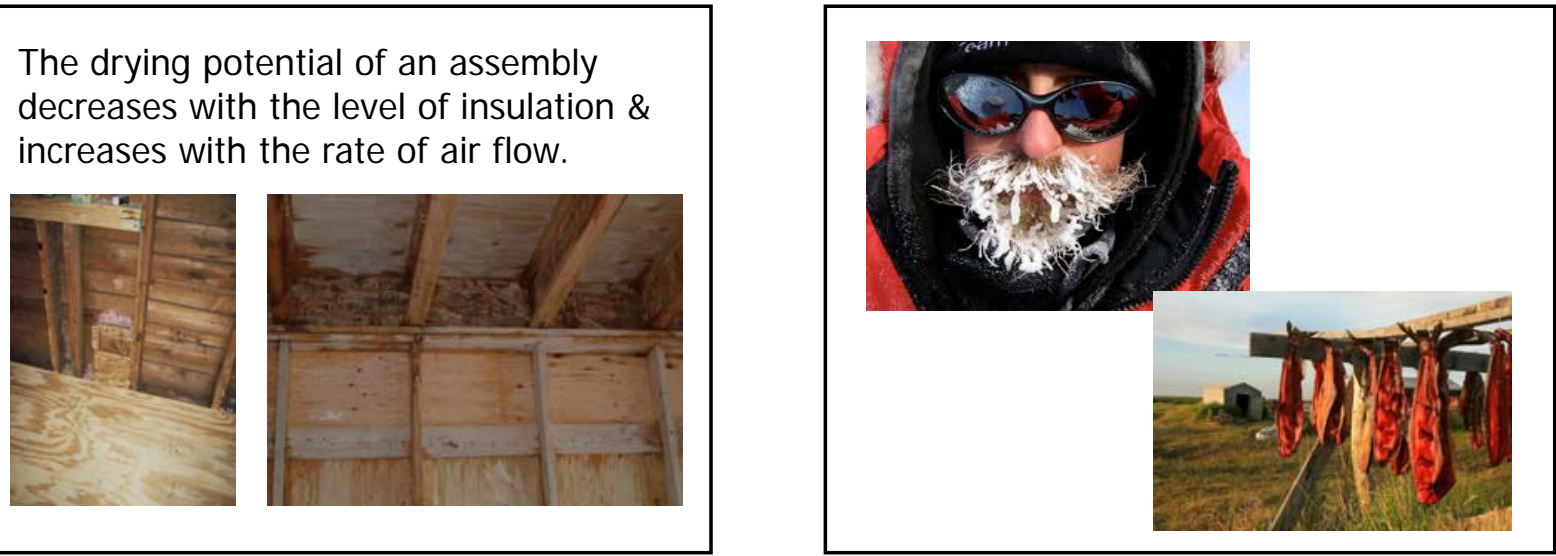

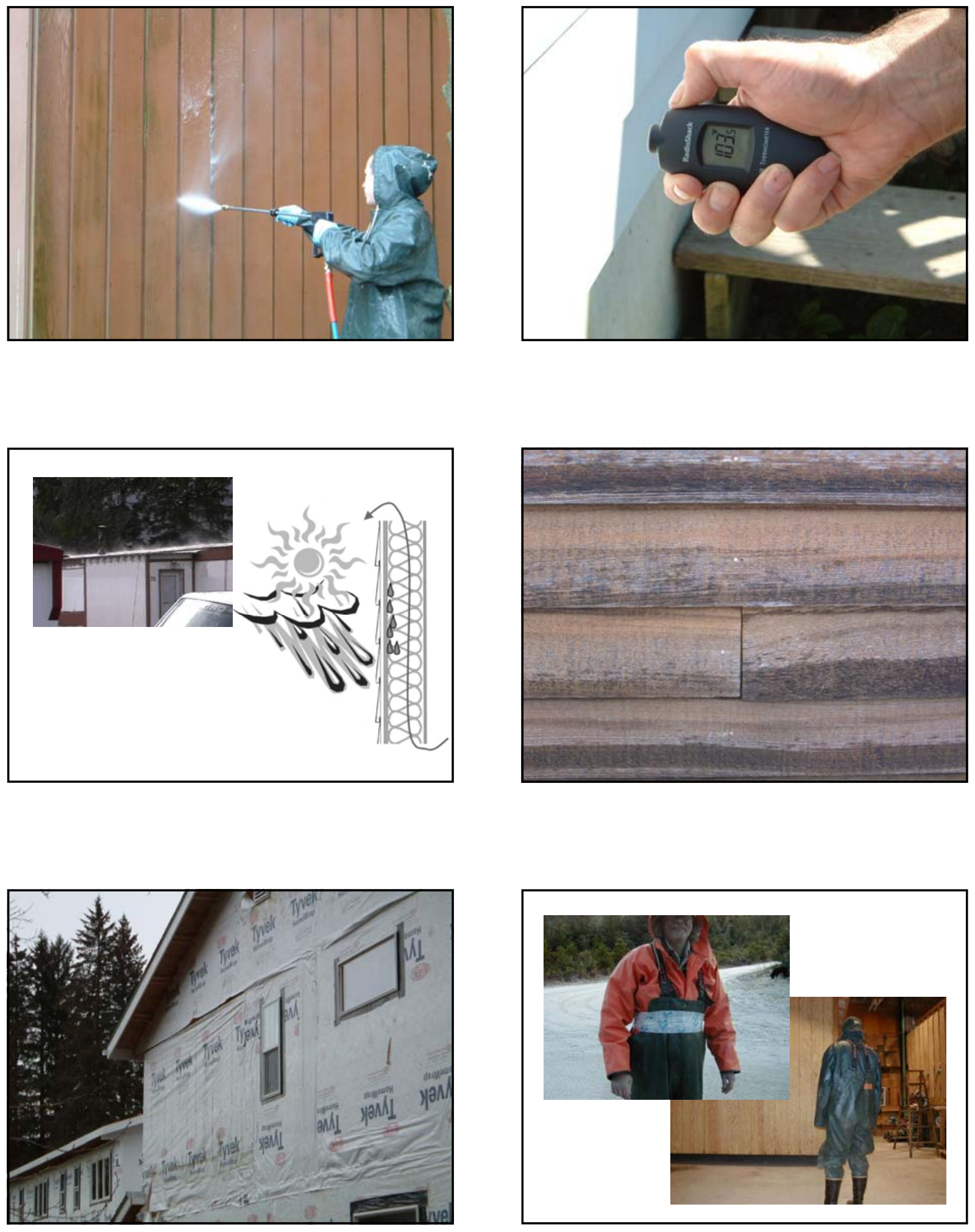

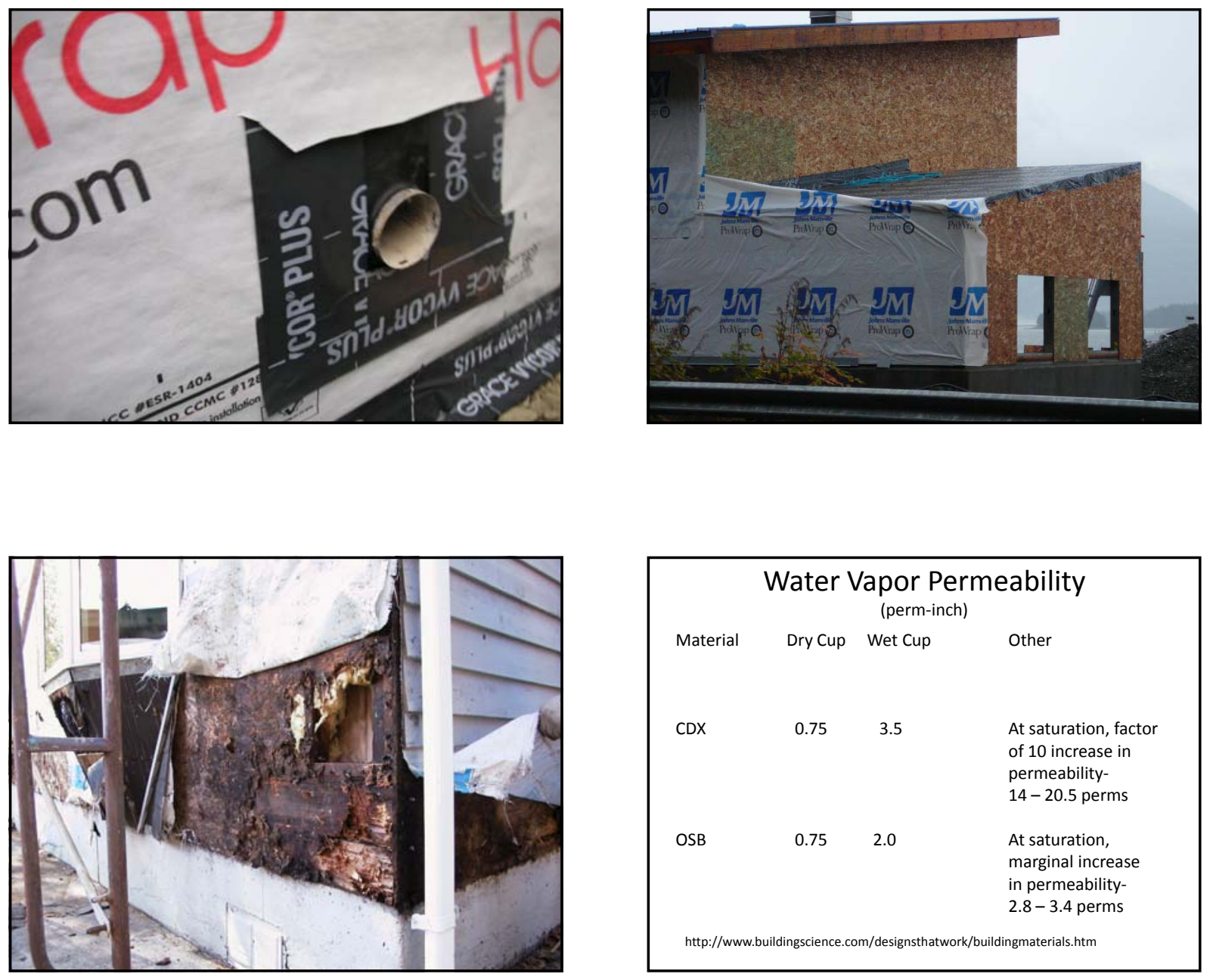

\begin{tabular}{|lccl|}
\hline \multicolumn{4}{|c|}{ Water Vapor Permeability } \\
Material & Dry Cup & $\begin{array}{c}\text { (perm-inch) } \\
\text { Wet Cup }\end{array}$ & Other \\
CDX & 0.75 & 3.5 & $\begin{array}{l}\text { At saturation, factor } \\
\text { of } 10 \text { increase in } \\
\text { permeability- } \\
14-20.5 \text { perms }\end{array}$ \\
& & & At saturation, \\
OSB & 0.75 & 2.0 & $\begin{array}{l}\text { marginal increase } \\
\text { in permeability- } \\
2.8-3.4 \text { perms }\end{array}$ \\
& & &
\end{tabular}

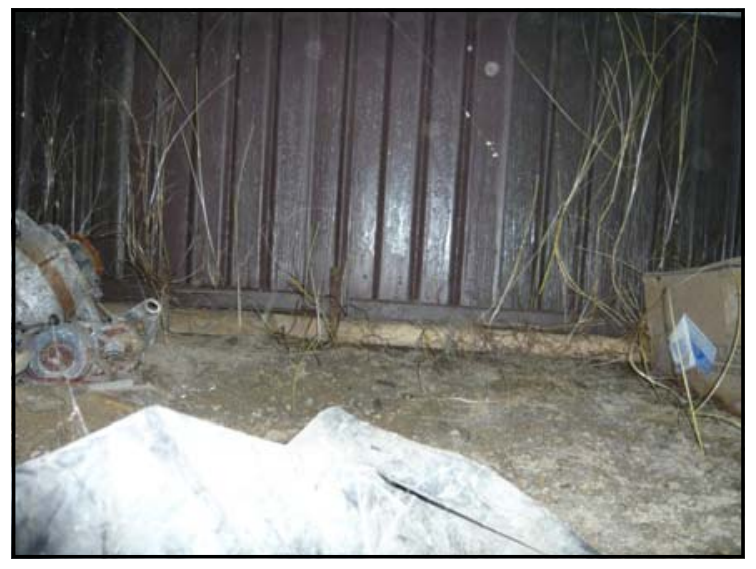

\section{Foundation Moisture Issues}

Foundation spaces account for the vast majority of moisture and IAQ issues in houses:

- Standing water caused by poor exterior or interior drainage

- Non existent or non functional sump systems

- Condensation on cool surfaces during warm humid periods

Saturated building or cellulose based materials lead to mold problems

- Resolve all major moisture issues before weatherizing home

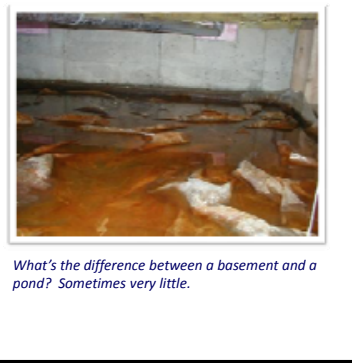



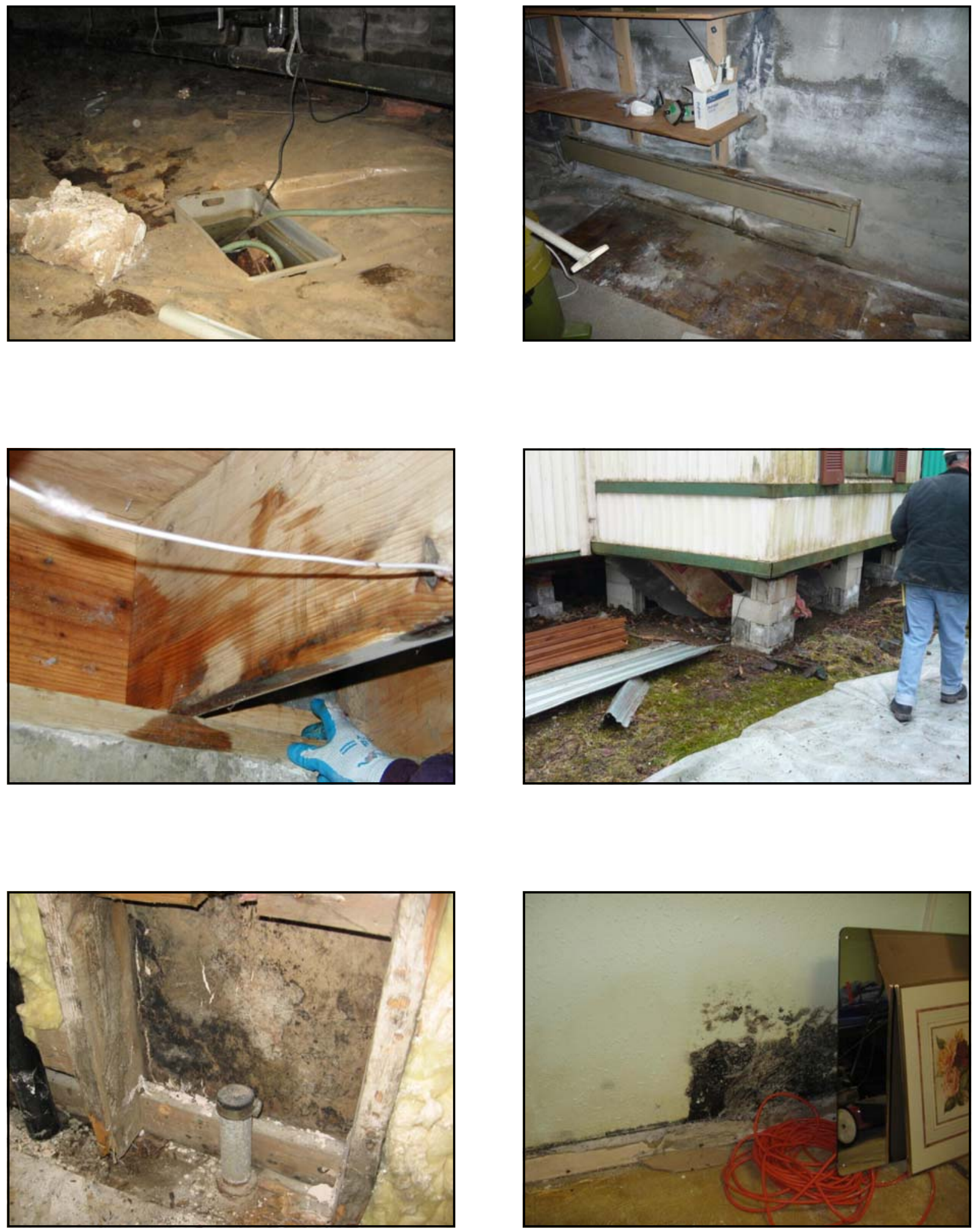

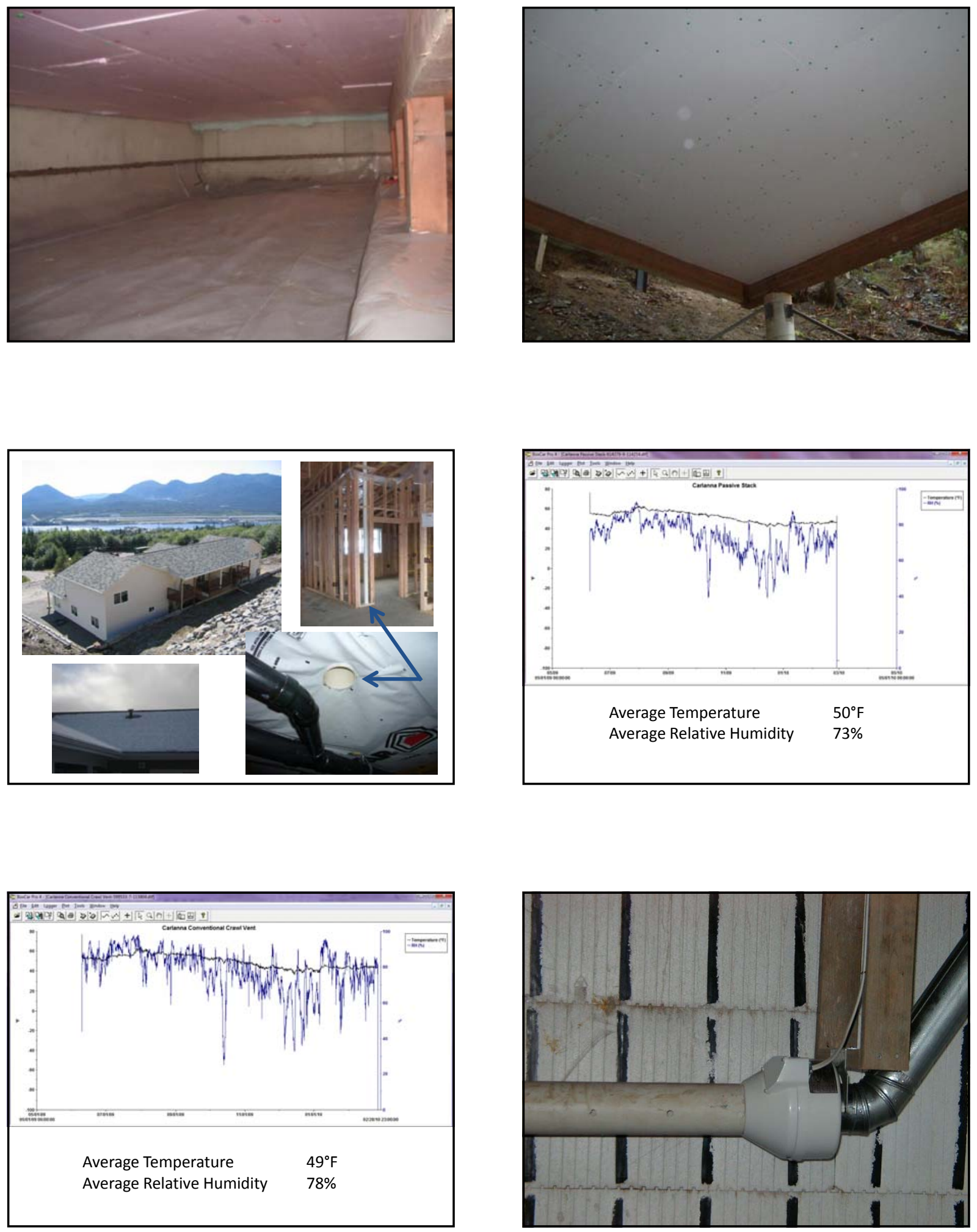

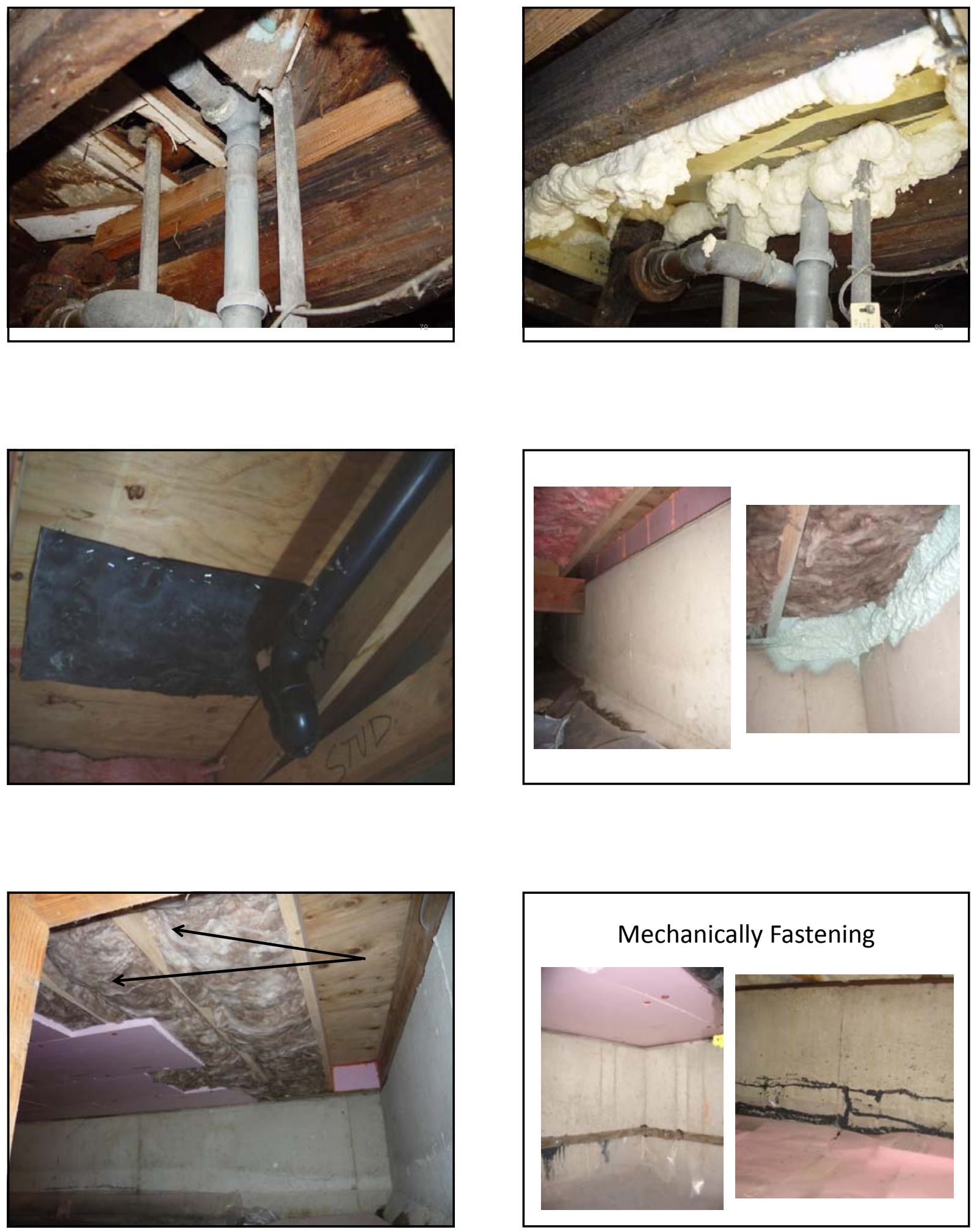

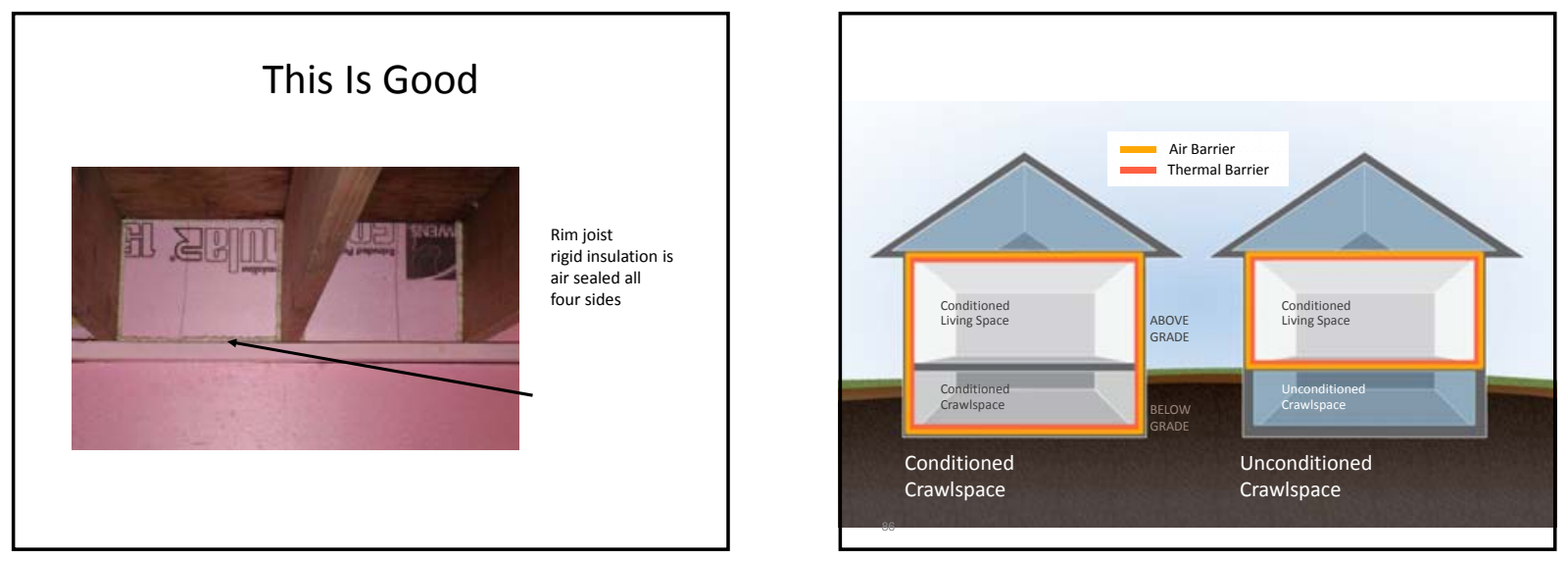

\section{Our Questions}

How to Weatherize an Underfloor Space

- Does it depend on the type of basement or crawlspace?

- Where are the pressure and thermal boundaries?

- Where should they be located?

- Even if the choice is clear, are the retrofits cost effective?

- What about moisture problems?

\section{Conditioned or Unconditioned?}

Guidelines

Conditioned

- More than $50 \%$ below grade

- Relatively tight or

unvented foundation

- A living space

- Intentional or unintentional space conditioning
Unconditioned

- Less than $50 \%$ below grade

- Leaky, vented, or severely degraded foundation

- Not a living space

- No intentional or unintentional space conditioning

- Water
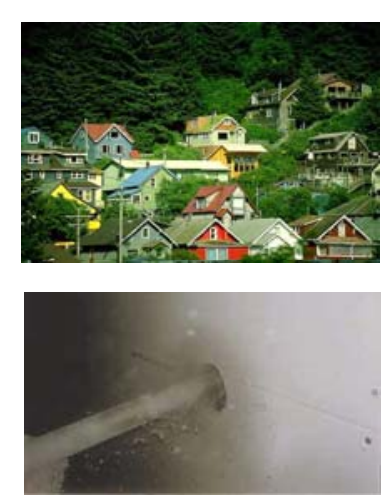

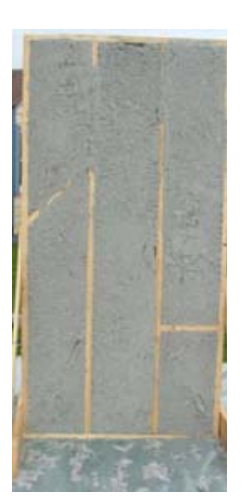

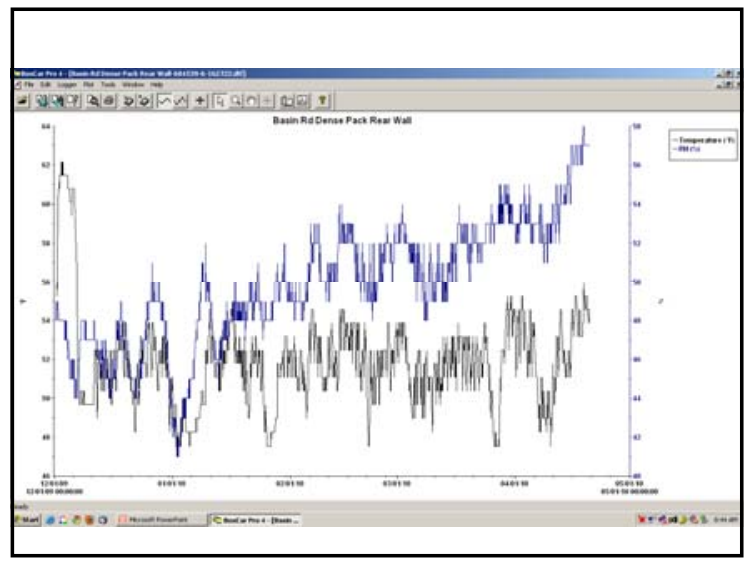



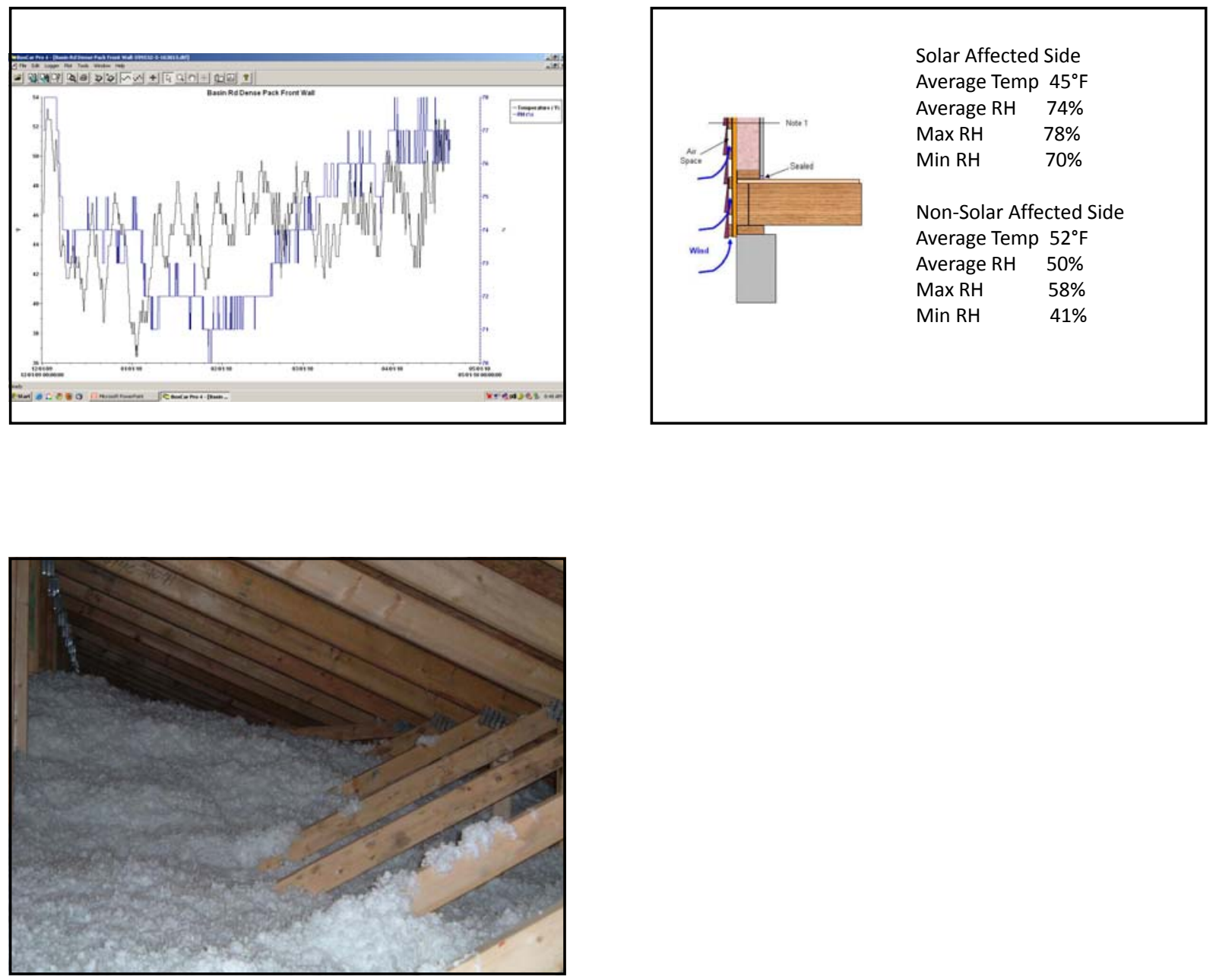


\section{Building Tightness Limit (BTL)}

1. Find your climate zone on the map.

2. Match that zone number with the same zone number on the table.

3. Identify the site as well-shielded, normal, or exposed.

4. Identify the column for your building's number of stories.

5. Follow that column down to where it meets the row corresponding to your climate zone and shielding to find n.

6. Use $\mathrm{n}$ to convert 50 Pascal airflows to natural or vice versa.

7. Find the building tightness limit (BTL). 


\section{Formulas}

$\mathrm{ACHn}=\quad \underline{\mathrm{ACH}_{50}}$

$n$

$\mathrm{ACH}_{50}=\quad \mathrm{ACHn} \times \mathrm{n}$

CFMn $=\frac{\text { CFM }_{50}}{\mathrm{n}}$

CFM50 $=\quad$ CFMn $\times n$

BTL (CFM50) X \# of occupants X $n$ 


\section{Climate Zone}

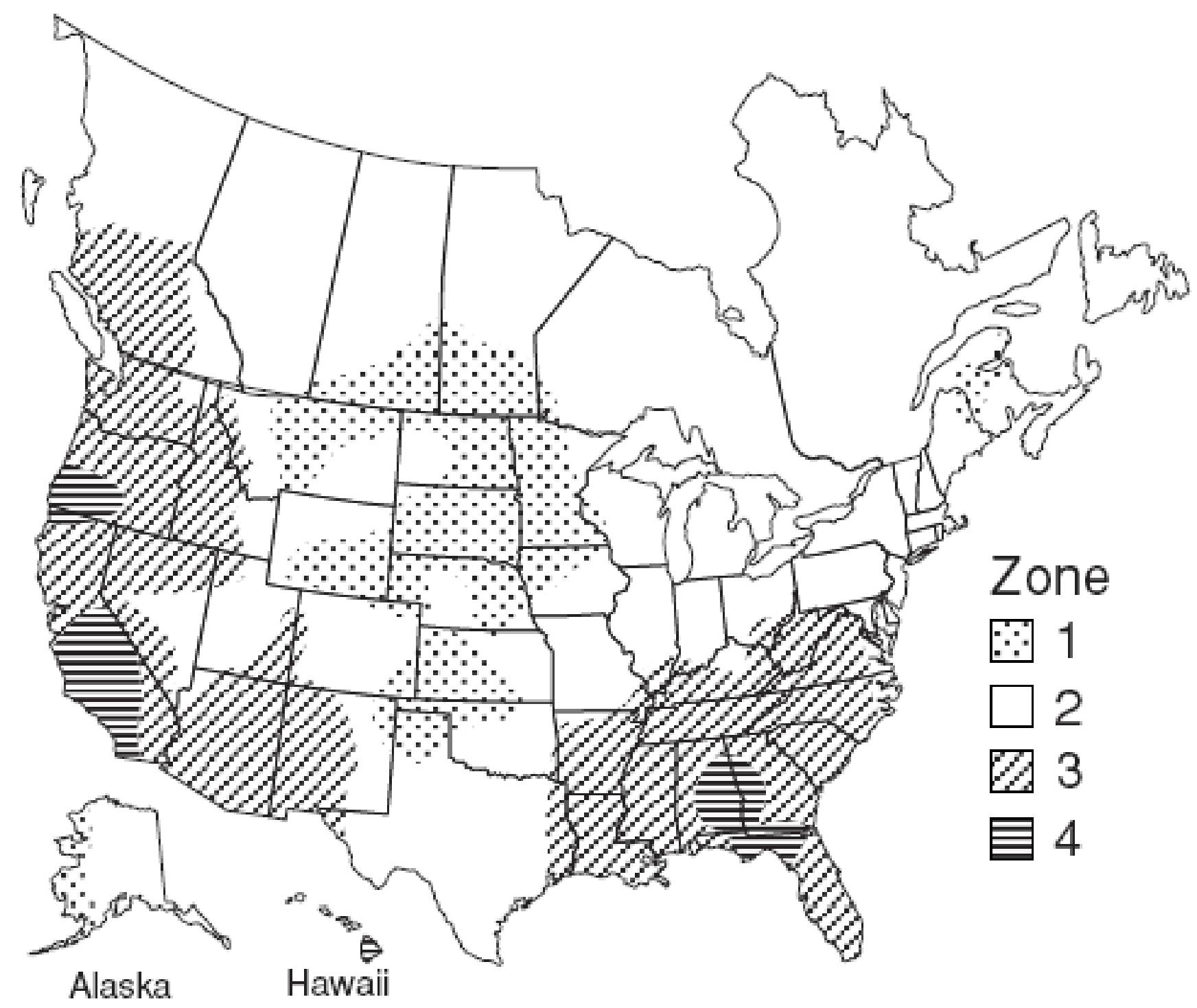




\section{n-Factor Table}

\begin{tabular}{|c|c|c|c|c|c|}
\hline Zone & $\#$ of stories $\rightarrow$ & 1 & 1.5 & 2 & 3 \\
\hline & Well-shi & 18.6 & 16.7 & 14.9 & 13.0 \\
\hline & Normal & 15.5 & 14.0 & 12.4 & 10.9 \\
\hline & Exposed & 14.0 & 12.6 & 11.2 & 9.8 \\
\hline \multirow{3}{*}{2} & Well-shie & 22.2 & 20.0 & 17.8 & 15.5 \\
\hline & Normal & 18.5 & 16.7 & 14.8 & 13.0 \\
\hline & Exposed & 16.7 & 15.0 & 13.3 & 11.7 \\
\hline \multirow{3}{*}{3} & Well-shielded & 25.8 & 23.2 & 20.6 & 18.1 \\
\hline & Normal & 21.5 & 19.4 & 17.2 & 15.1 \\
\hline & Exposed & 19.4 & 17.4 & 15.5 & 13.5 \\
\hline \multirow{3}{*}{4} & Well-shielded & 29.4 & 26.5 & 23.5 & 20.6 \\
\hline & Normal & 24.5 & 22.1 & 19.6 & 17.2 \\
\hline & Exposed & 22.1 & 19.8 & 17.6 & 15.4 \\
\hline
\end{tabular}




\section{Determining Minimum Ventilation Rate}

Formula \#1: $\quad 15 \mathrm{cfm} x$ the number of occupants $\times n=$ CFM50 BTL

Formula \#2: $\quad 15 \mathrm{cfm} \times$ number of bedrooms

$+15 \times n=$ CFM50 BTL

Formula \#3: $\quad$ Volume of conditioned space $x$ $0.35 \times \mathrm{n} / 60=$ CFM50 BTL 


\section{Why Test Combustion Appliances?}

We test to assure:

- Health and safety

- Building integrity

- Comfort

- Energy efficiency

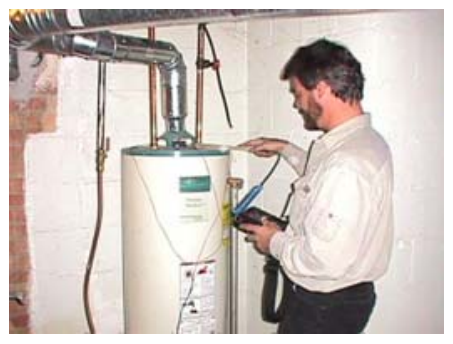

\section{What to Inspect - Visual}

What do we inspect on

combustion appliances?

-Chimney safety

-Vent pipes

-Wiring

- Heat exchanger

-Distribution systems

-Combustion air

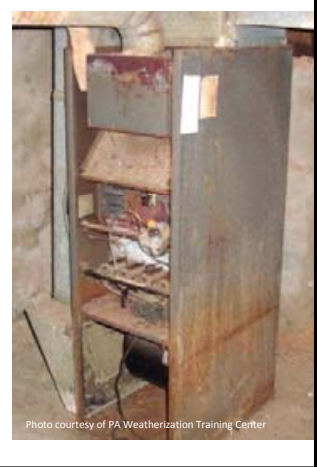

\section{Carbon Monoxide from Incomplete Combustion}

\section{Co Occurs When:}

- The ratio of fuel to oxygen is either too high to permit the complete formation of $\mathrm{CO}_{2}$ or..........

- The temperature is too low to permit complete burning to occur.

Caused by:

- Too much fuel for the amount of oxygen

- Not enough oxygen for the amount of fuel

- Not enough heat (flame impingement)

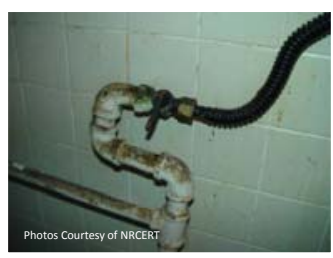

Test all joints, valves and fittings.

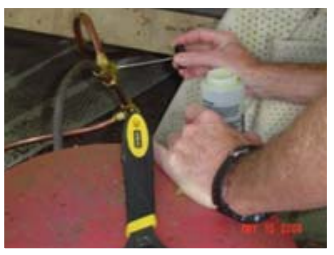

Use soap bubbles to confirm a leak.

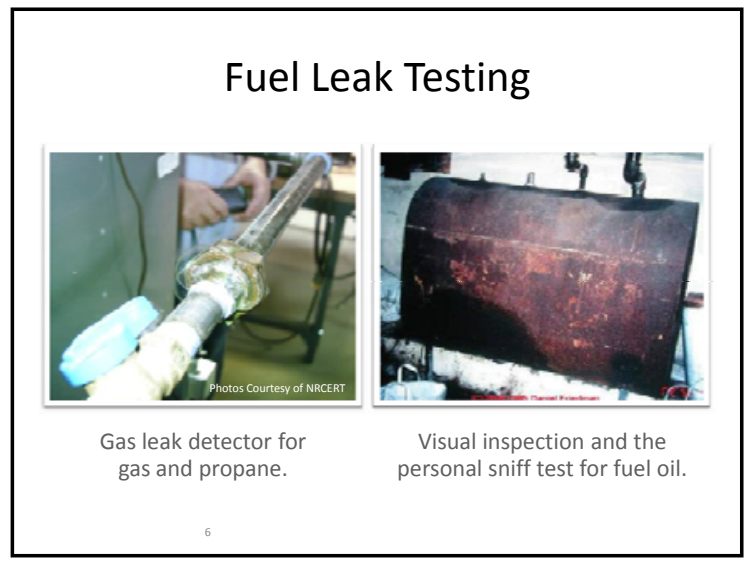



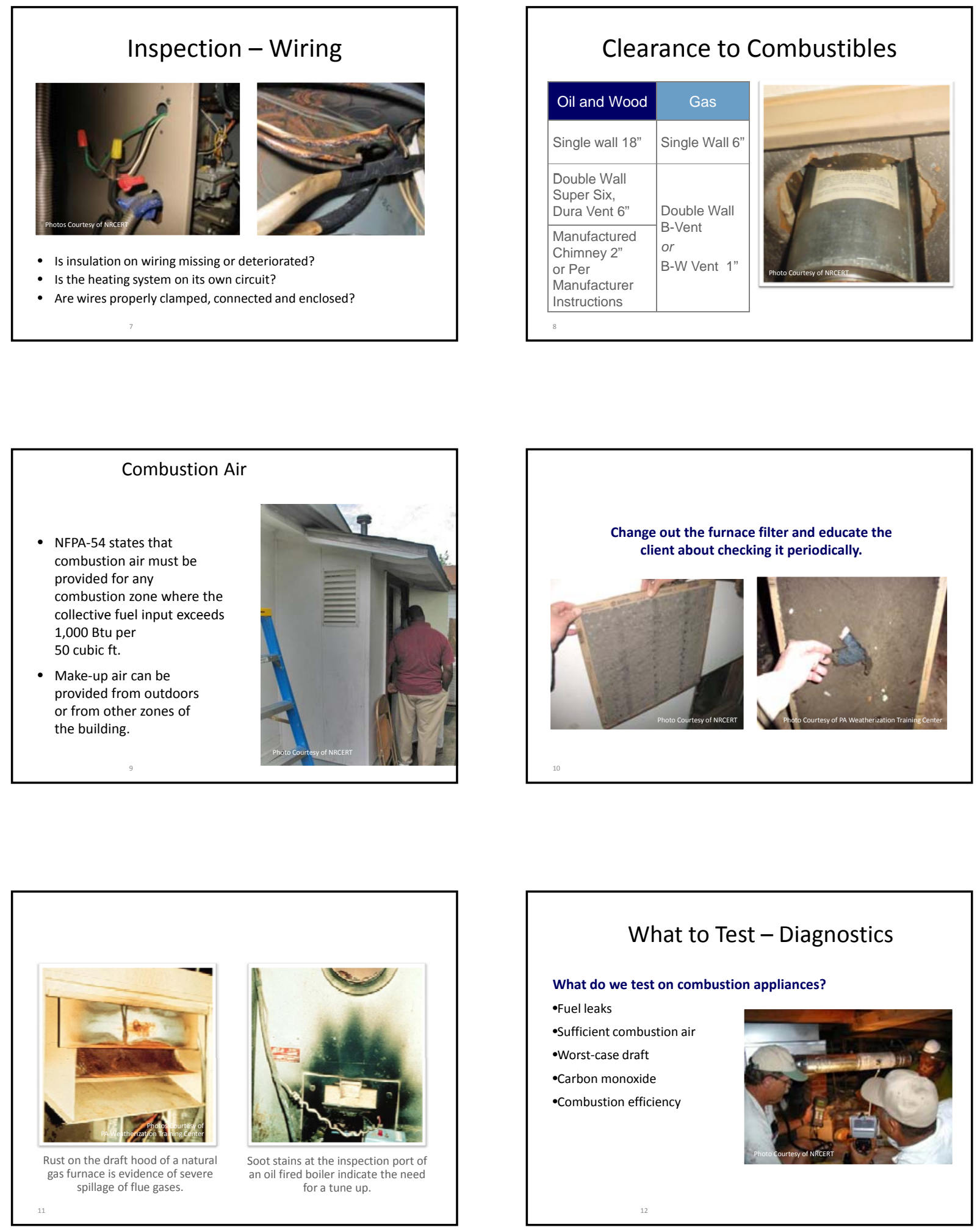

\section{What to Test - Diagnostics}

What do we test on combustion appliances?

-Fuel leaks

-Sufficient combustion air

-Worst-case draft

-Carbon monoxide

-Combustion efficiency

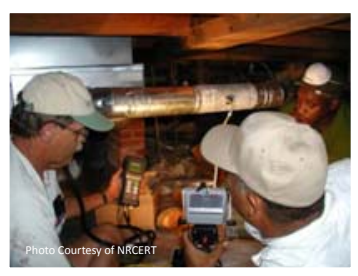



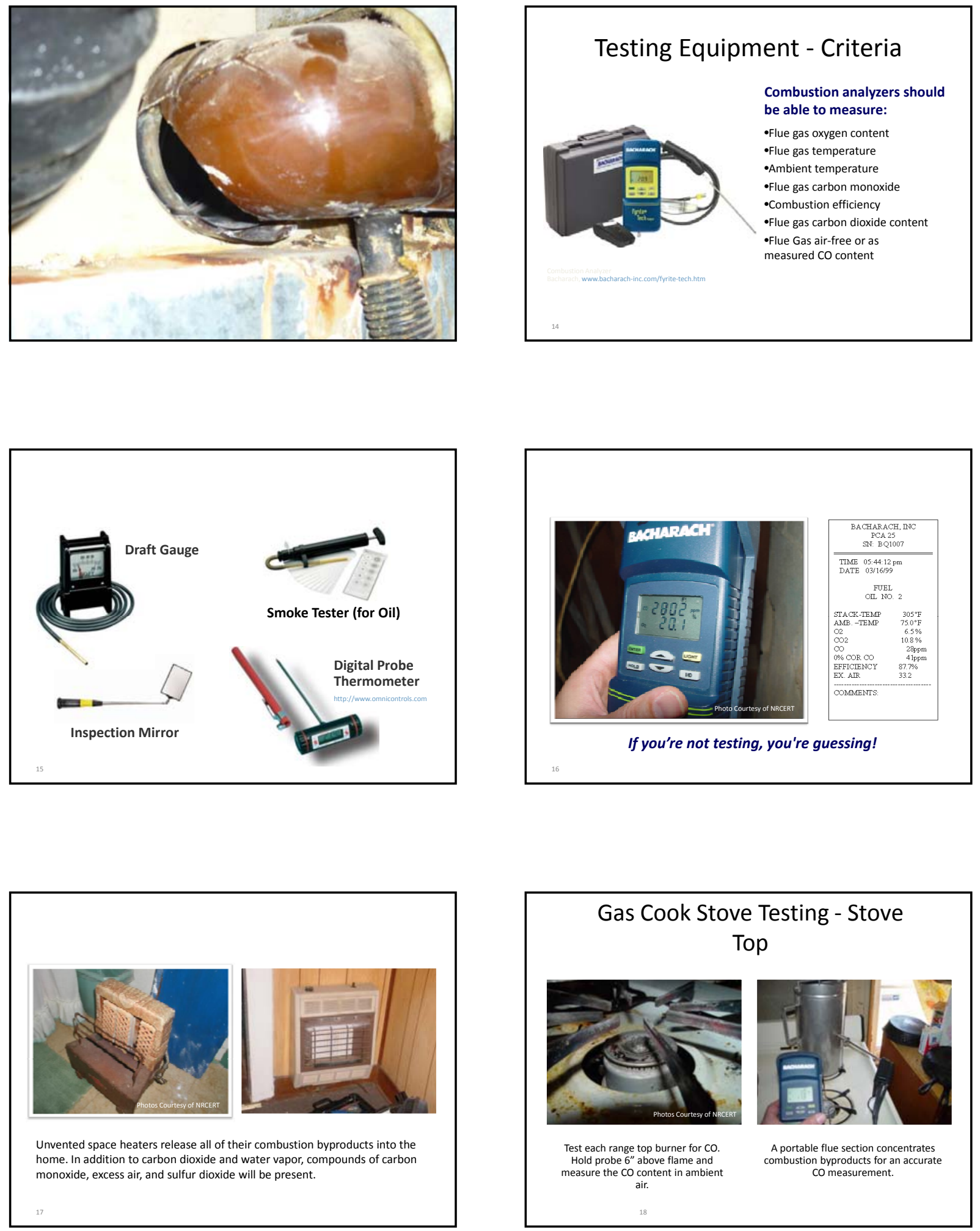

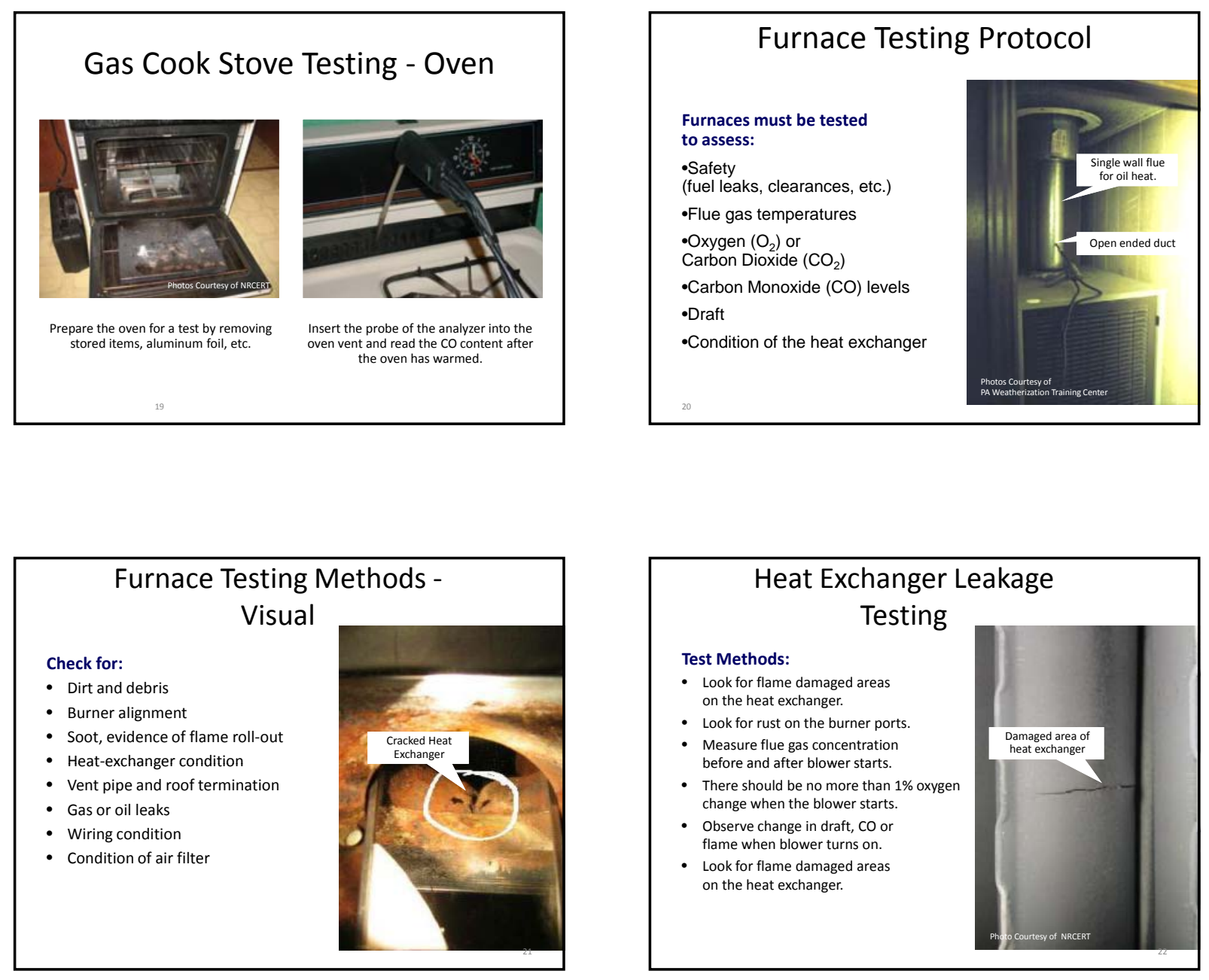

\section{Inspection - Heat Exchanger}

- Use a strong light and an inspection mirror.

- Is the heat exchanger rusty?

- Are there cracks?

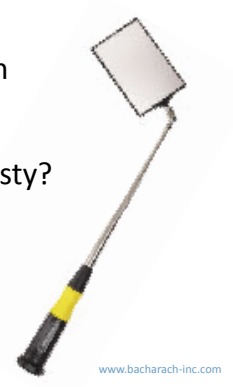

\section{Survey Combustion Appliances}

- Furnaces

- Water heaters

- Fireplaces

- Woodstove

- Auxiliary heating devices

- Clothes dryers

- Cooking stoves 


\section{Minimum Draft Pressures}

oDrill a small hole in the vent pipe 2 feet downstream of the draft divertor or barometric damper. Insert a static pressure probe.

o Measure draft pressure (vent WRT combustion room) with the digital gauge after 5 minutes of operation.

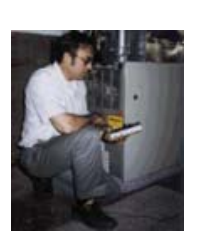

\begin{tabular}{ll} 
Outside Temp & Draft Pressure \\
\hline Below $10 \mathrm{~F}$ & $-2.50 \mathrm{~Pa}$ \\
$20 \mathrm{~F}$ & $-2.25 \mathrm{~Pa}$ \\
$40 \mathrm{~F}$ & $-1.75 \mathrm{~Pa}$ \\
$60 \mathrm{~F}$ & $-1.25 \mathrm{~Pa}$ \\
$80 \mathrm{~F}$ & $-0.75 \mathrm{~Pa}$ \\
Above $90 \mathrm{~F}$ & $-0.50 \mathrm{~Pa}$
\end{tabular}

\section{House Depressurization Limits}

- Type 1-5 Pa - Naturally Aspirating - relies on buoyancy of the hot flue gases to rise in the chimney

- Type 2-10 Pa - Induced-Maintains negative pressure in the chimney. Fan often at point of exit of the building.

- Type 3-20 Pa - Forced - Maintains a positive pressure in the chimney. Chimney must be air tight.

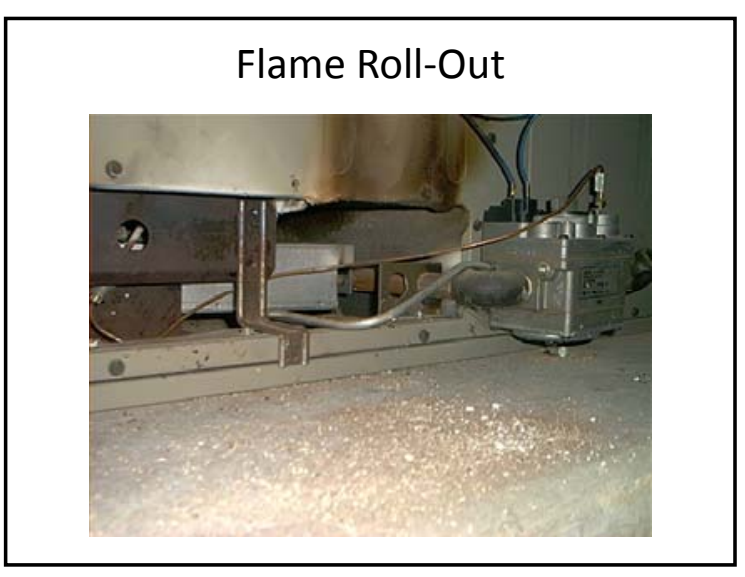

\section{Setting Up Worst Case Conditions}

- Record outdoor temperature.

- Clean dryer lint filter and furnace filter.

- Deactivate all combustion appliances.

- Close all exterior doors and windows.

- Open interior doors containing exhaust fans.

- Close all other interior doors.

\section{Conducting a Worst Case Test}

- Record the pressure difference of the CAZ

with respect to outdoors using a manometer.

- Operate all exhaust devices.

- Record the pressure difference of the CAZ with respect to outdoors.

- Conduct CO, spillage, and draft tests under worst case conditions.

- Open and close interior doors (including door to CAZ).

- Repeat for all other vented appliances.

- Return dwelling, exhaust fans, and combustion appliances to normal settings.

- Location, type and input of combustion appliance

- Signs of visible deterioration and leaks in flue pipes and connections

- Presence of fuel leaks, spillage or flame rollout

- Location, size and condition of combustion air supply

- Evidence of cracked or rusted interior surface of heat exchanger 


\section{Measure WCD - Fans}

\section{Preparation}

1. Close all exterior doors, windows and be sure vented combustion appliances are off

2. Close all interior doors

3. Measure $\triangle \mathrm{P}$ of CAZ with WRT outside pressure
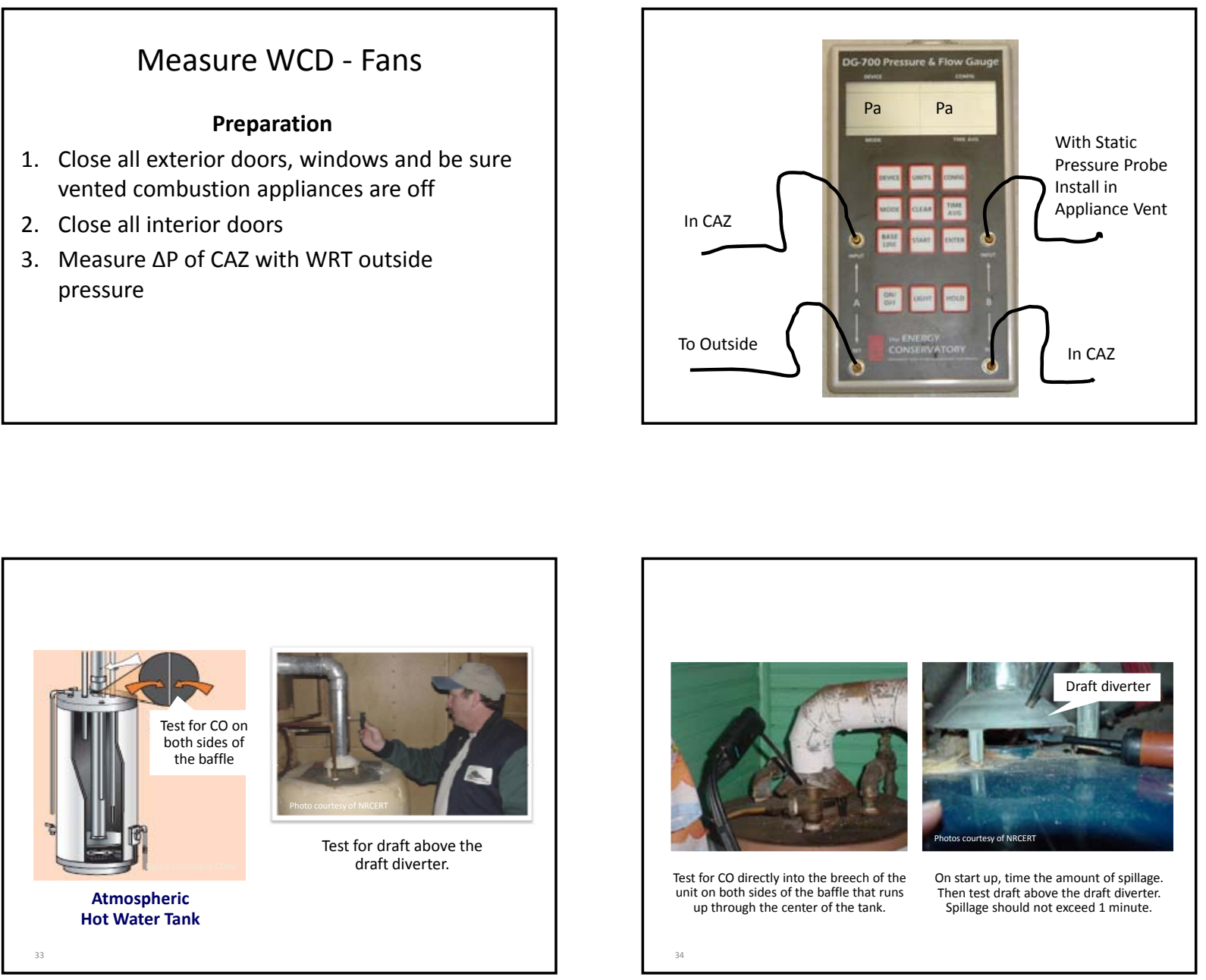

Spillage, Draft and CO

Spillage

- Test at vent openings, i.e. dilution air openings, barometric damper, with smoke.

Draft

- Test in vent connection between last opening in vent connect and chimney.

- Oil burners - Test over fire in combustion chamber.

CO

- Test at appliance breech, between appliance and first opening in vent connect or directly above heat exchanger.

- Condensing gas appliances - Test at vent termination.

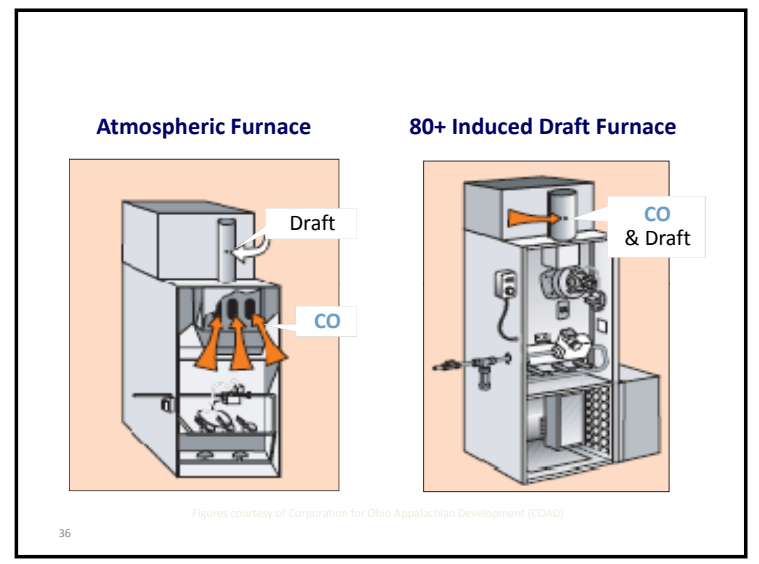


Combustion Safety Problems - Fixes

Solve excessive depressurization or inadequate draft: - Repair chimney obstructions, disconnections, or leaks.

-Properly size the vent, connector, or liner.

-Install a metal chimney liner and/or a wind-rated chimney cap.

-Seal leaks in the return ducts of the CAZ.

-Balance supply and return air by adding new returns, or by

adding passive return air openings to the main body of the house.

- Reduce capacity of large exhaust fans.

-Provide make-up air for dryers and exhaust fans.

-Provide combustion air inlet to CAZ.

\section{Venting Systems}

A Venting System should:

- Carry all combustion byproducts to outdoors

- Establish draft quickly

- Be properly sized with minimal restrictions

- Have long durability (corrosion resistance)

- Not overheat surrounding materials

- Have adequate make up air 
Thermal/Pressure Boundaries;

Are They About...

\section{Energy}

Healthy IAQ

Durability

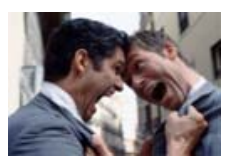

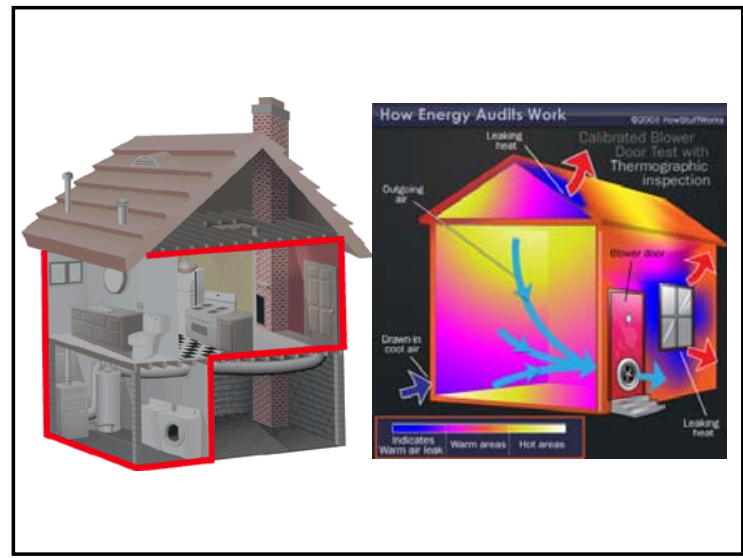
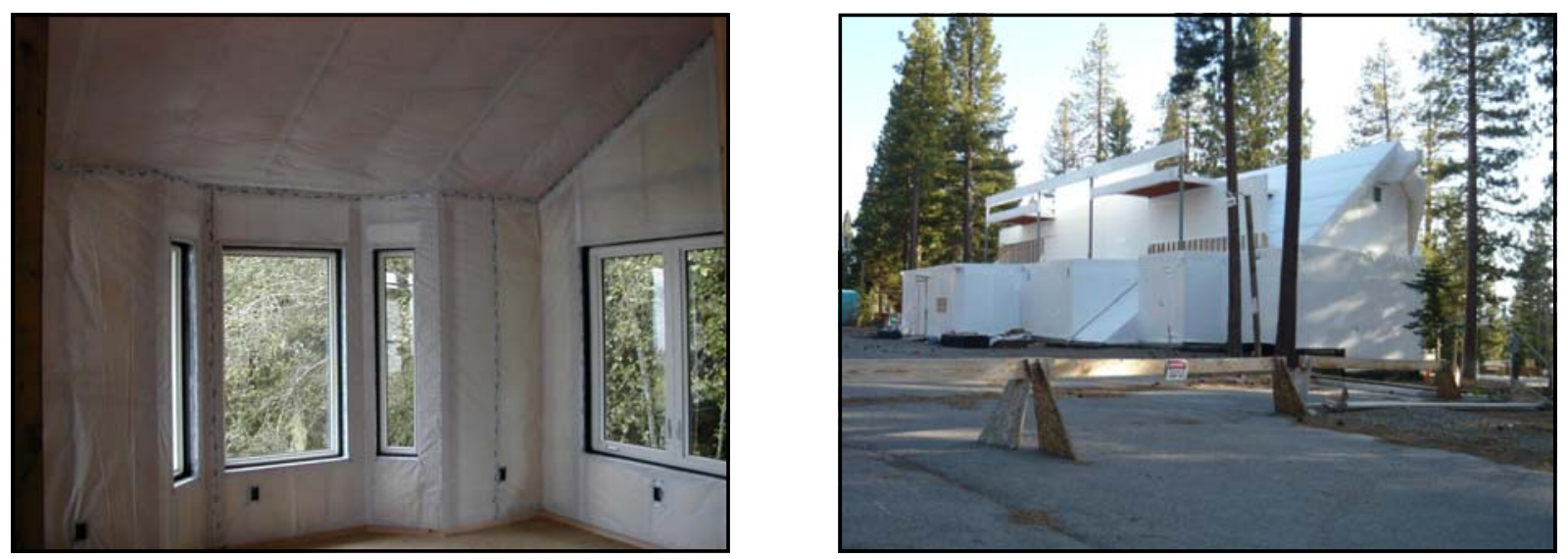

\section{Objectives}

- Understand the difference between thermal and air barriers

- Know the proper location of thermal and air barriers

- Recognize the driving forces of air leakage

- Understand the connection between air leakage, energy waste, and moisture problems

- Understand how air ducts effect pressure balance within the home

- Understand the principle behind the blower door as a tool for measuring air leakage

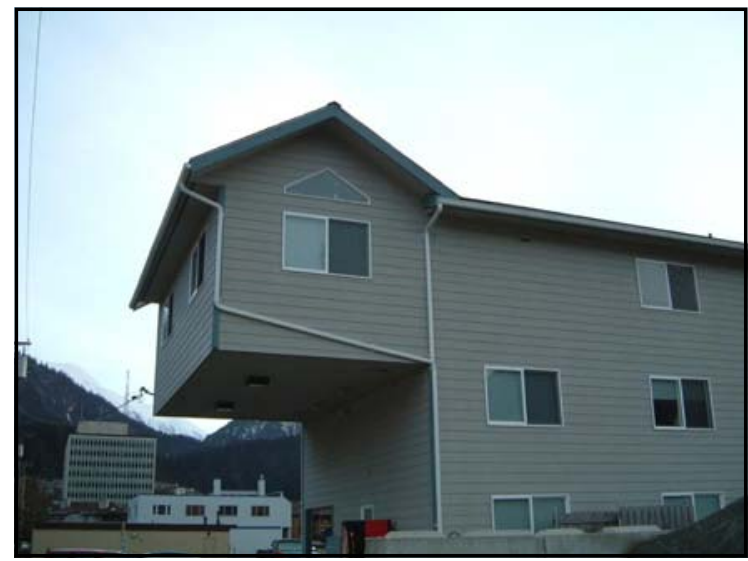



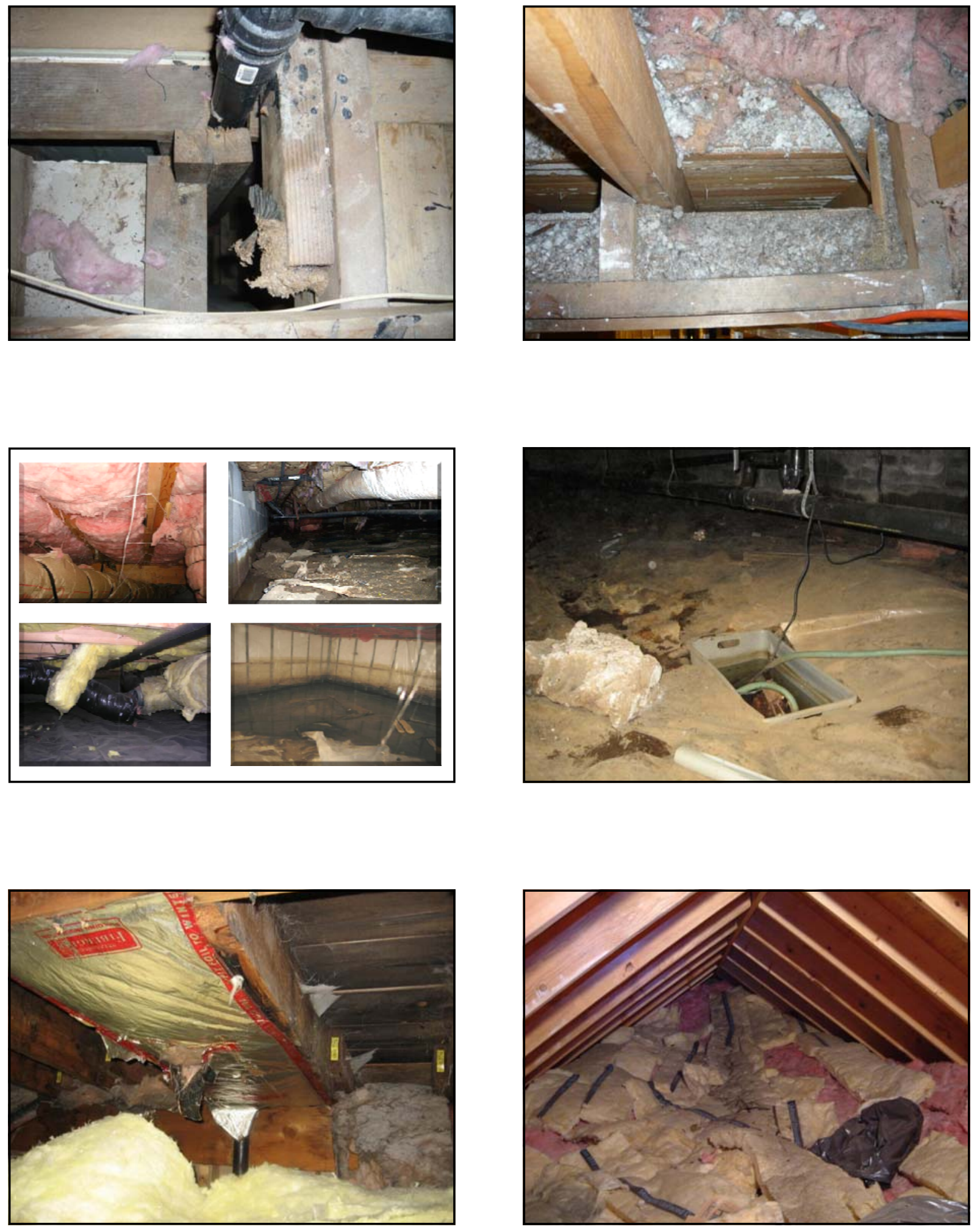

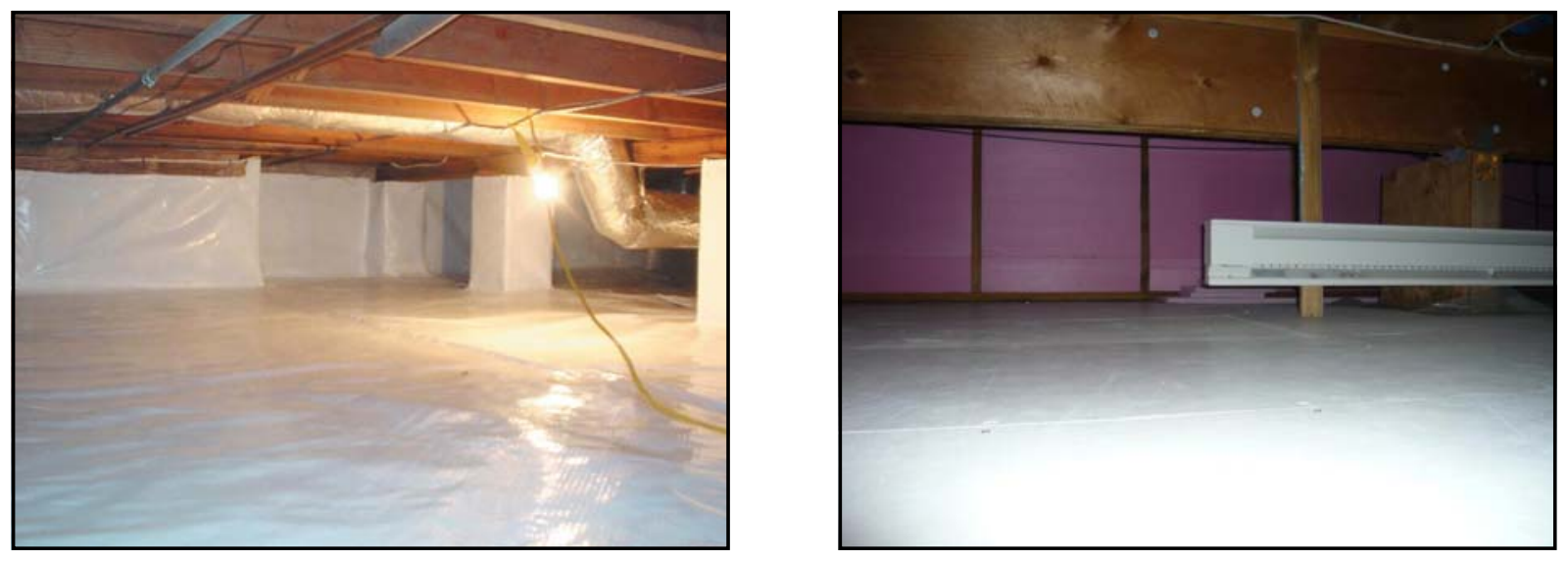

\section{Thermal Boundary}

The Thermal Boundary:

- Limits heat flow between inside and outside

- Easy to identify by presence of insulation

- The location of insulation in relation to other building components is critical to its effectiveness

- Even small areas of missing insulation are very important

Voids of $7 \%$ can

reduce effective R-value

by almost $50 \%$
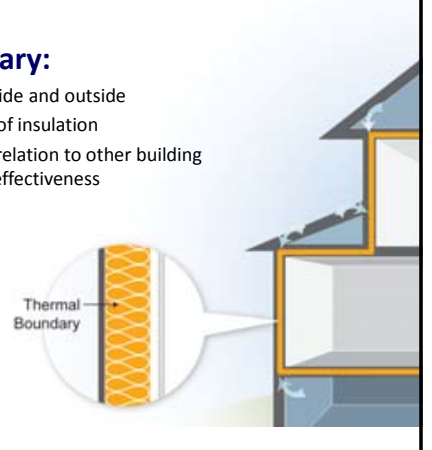

The Thermal Boundary is Obvious

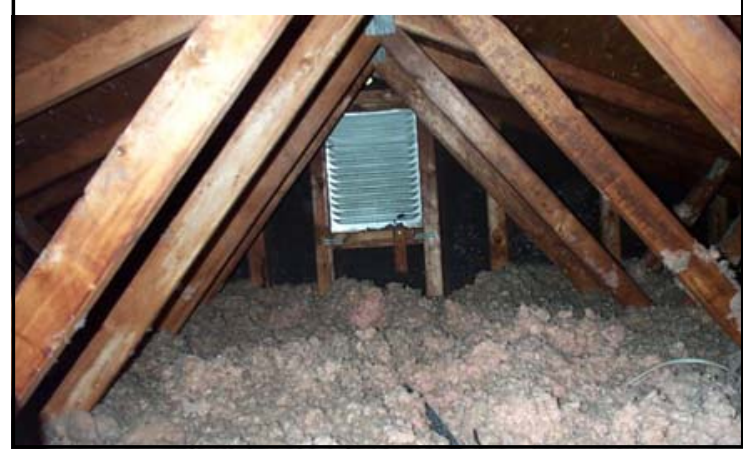

\section{Air Barrier}

The Air Barrier:

- Limits air flow between inside and outside

- More difficult to identify

- Not always where you think it is

- Blower door is used to locate air barrier

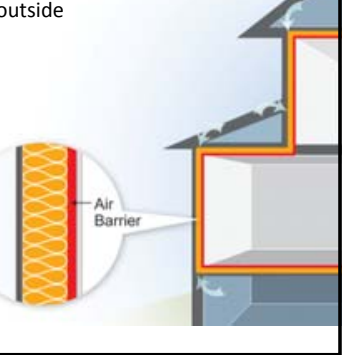

\section{Thermal \& Air Barriers}

For maximum efficiency and comfort,

the thermal and air barriers must be continuous

and in contact with each other.

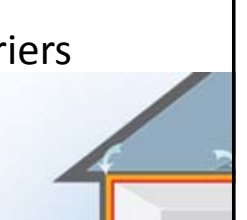



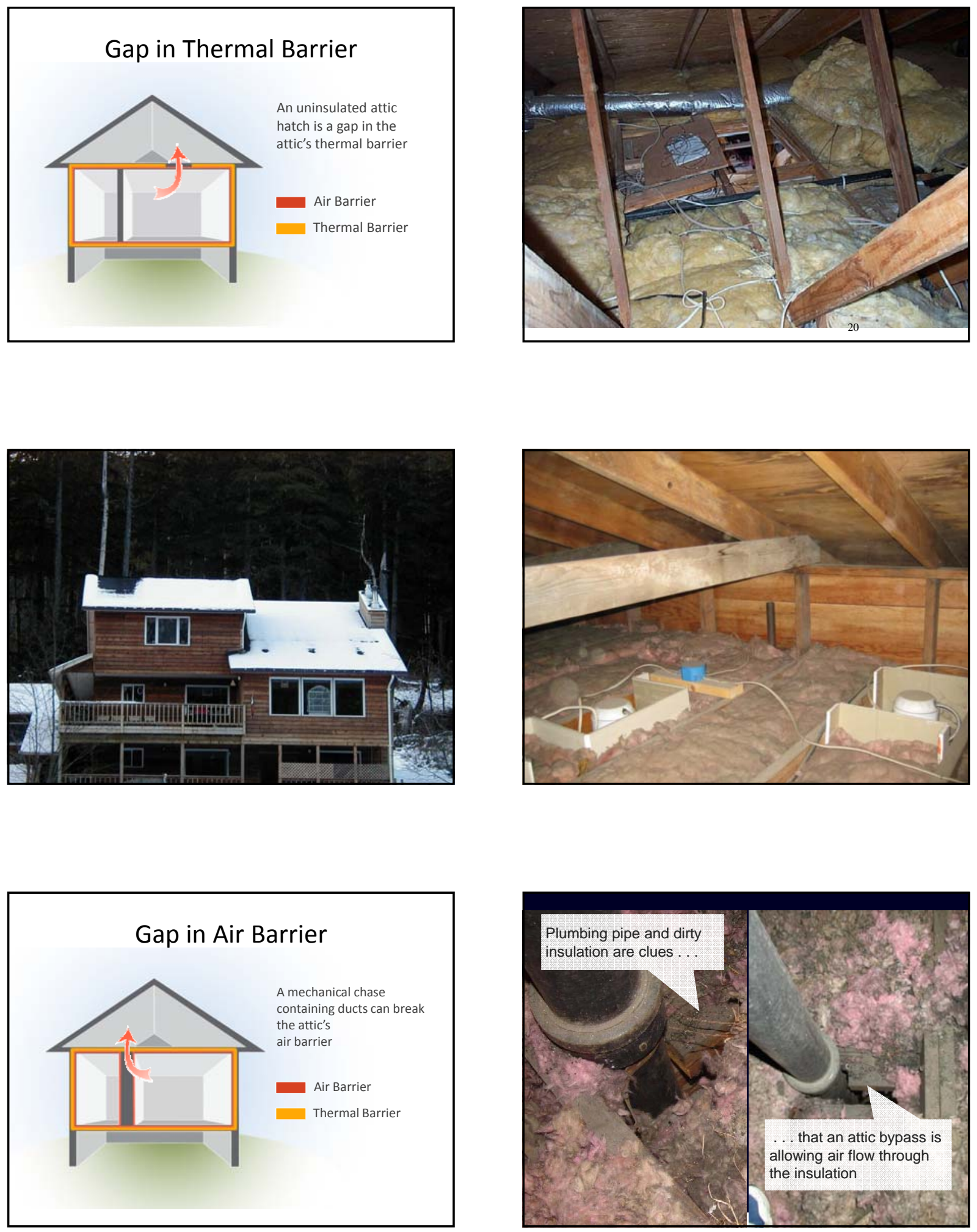

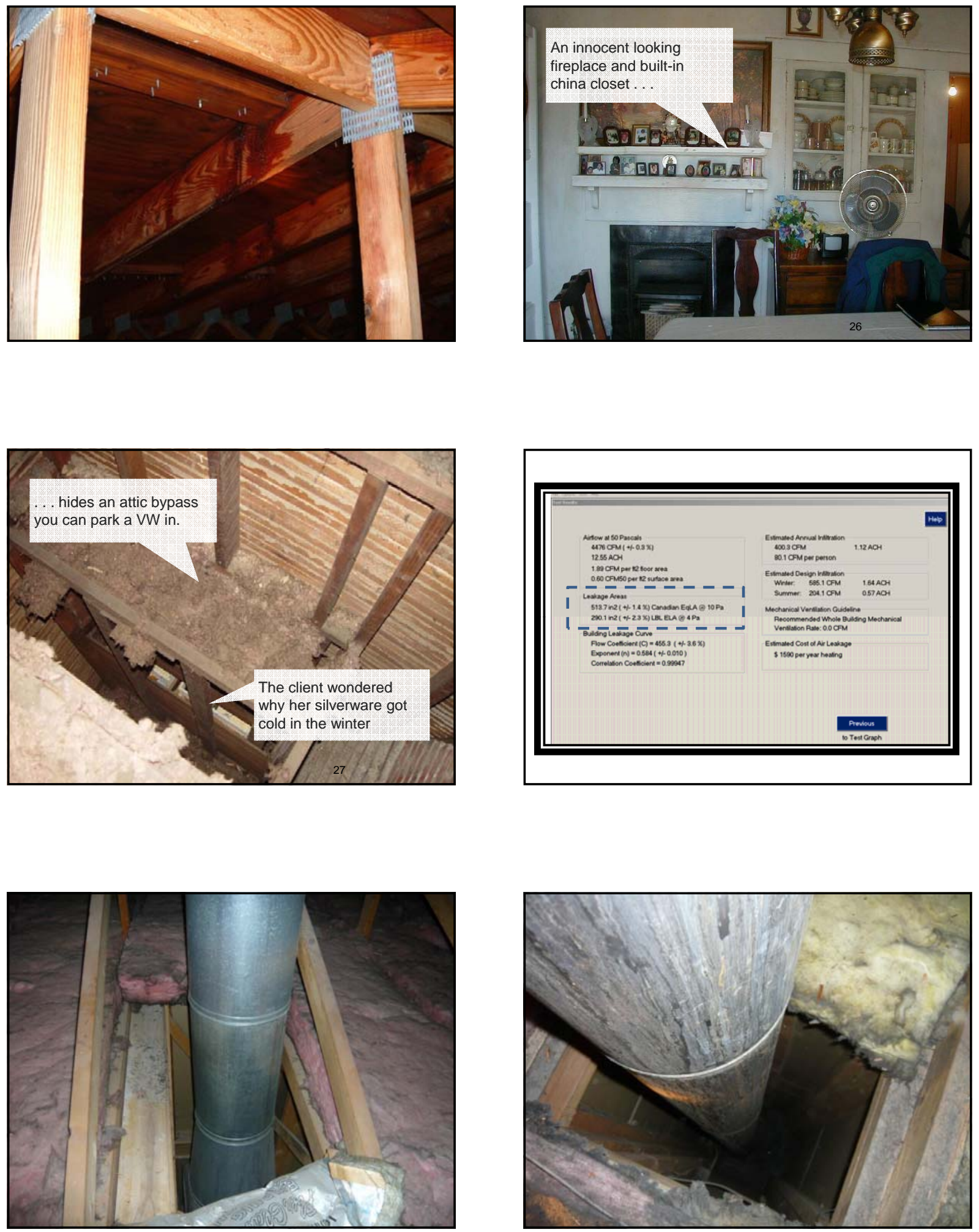

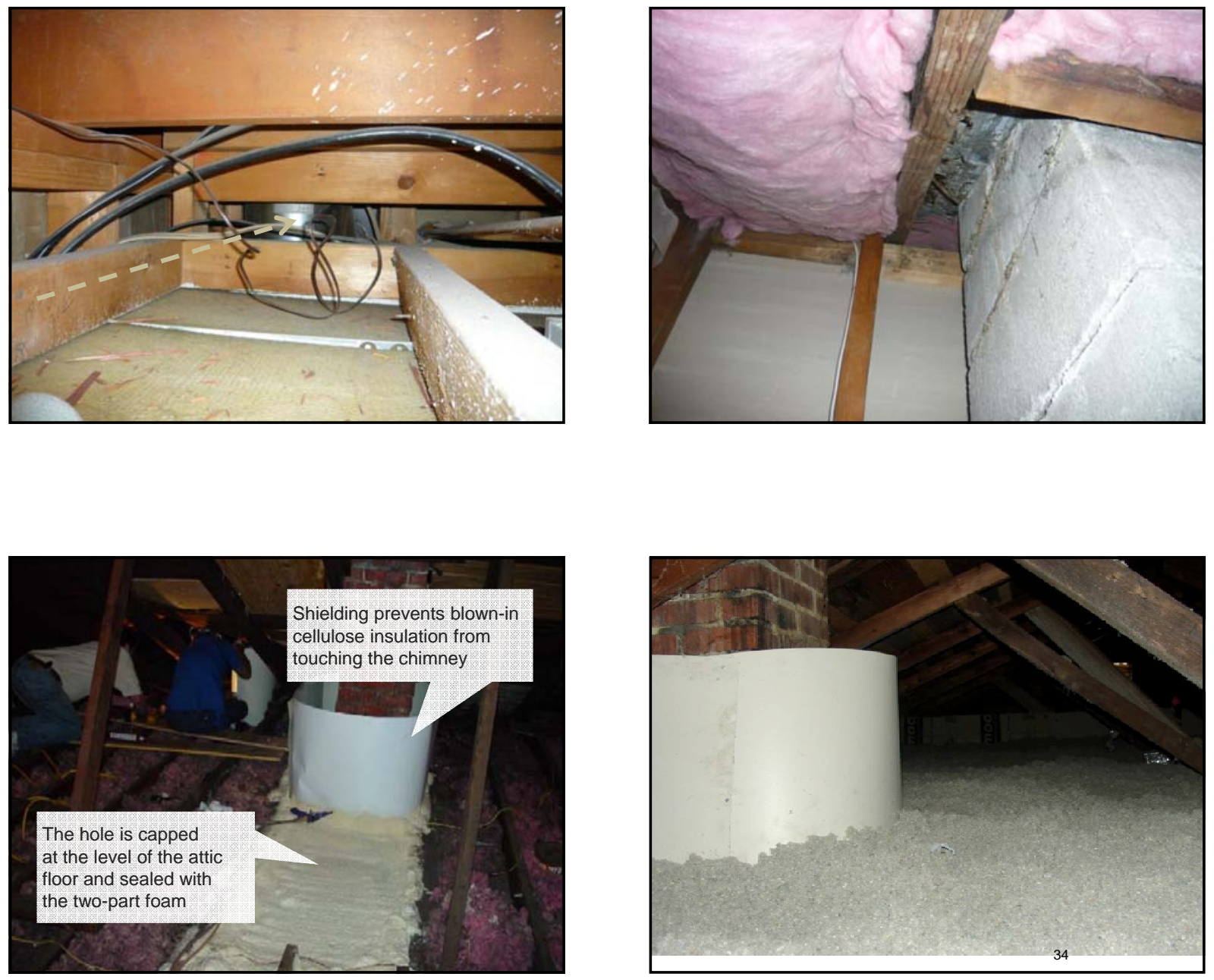

\section{Construction Details}

Other construction details that result in gaps in pressure and thermal barriers:

0 Changes in ceiling height

o Kneewall attics

o Walk-up attics
- Dropped soffits

o Above kitchen cabinets

o Bathrooms

o Above vanities

o Above built-ins

o Duct chases/bulkheads

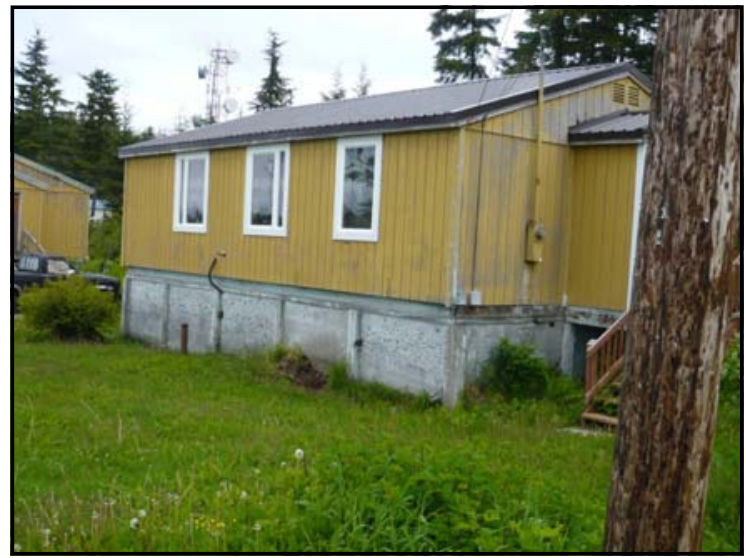



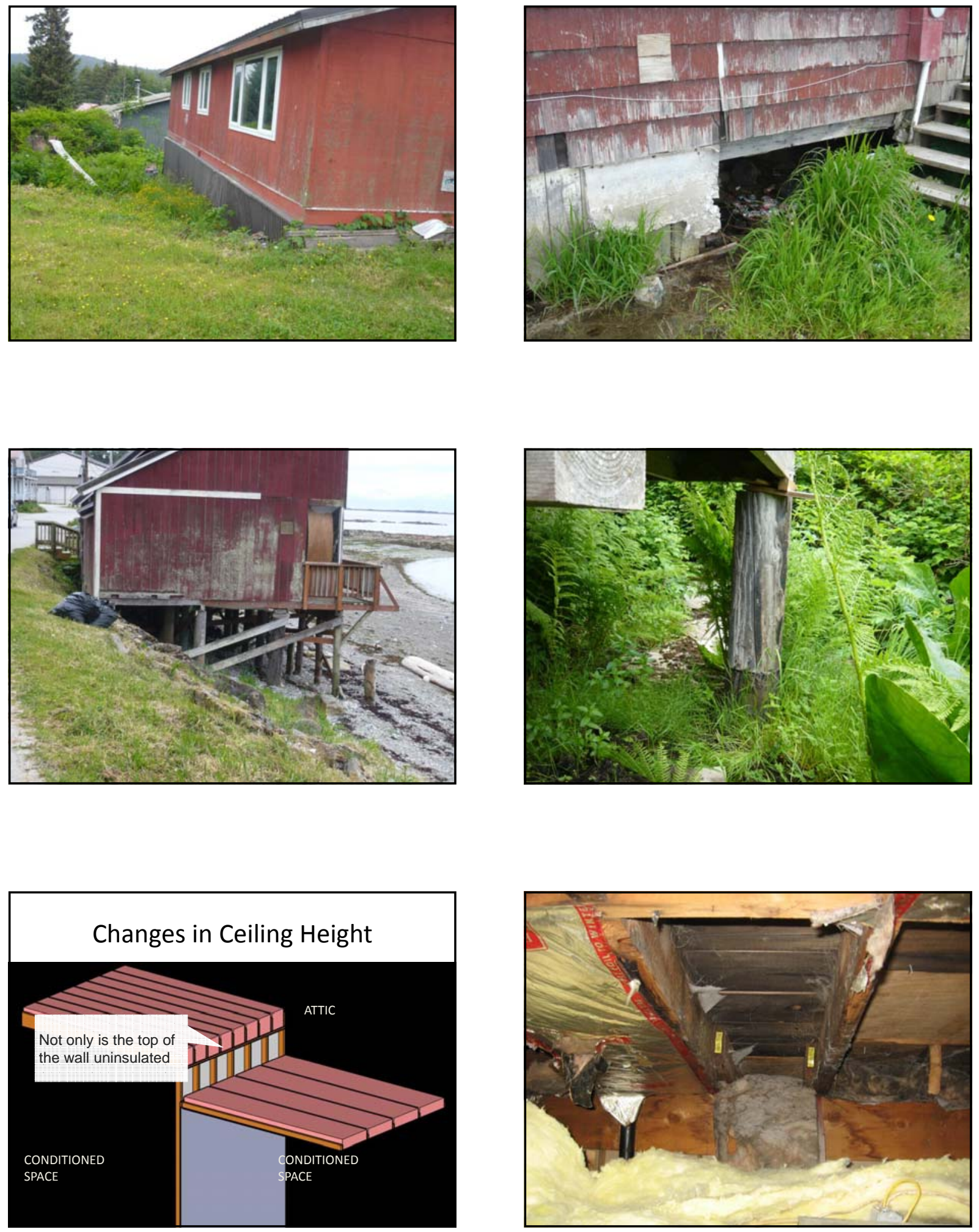

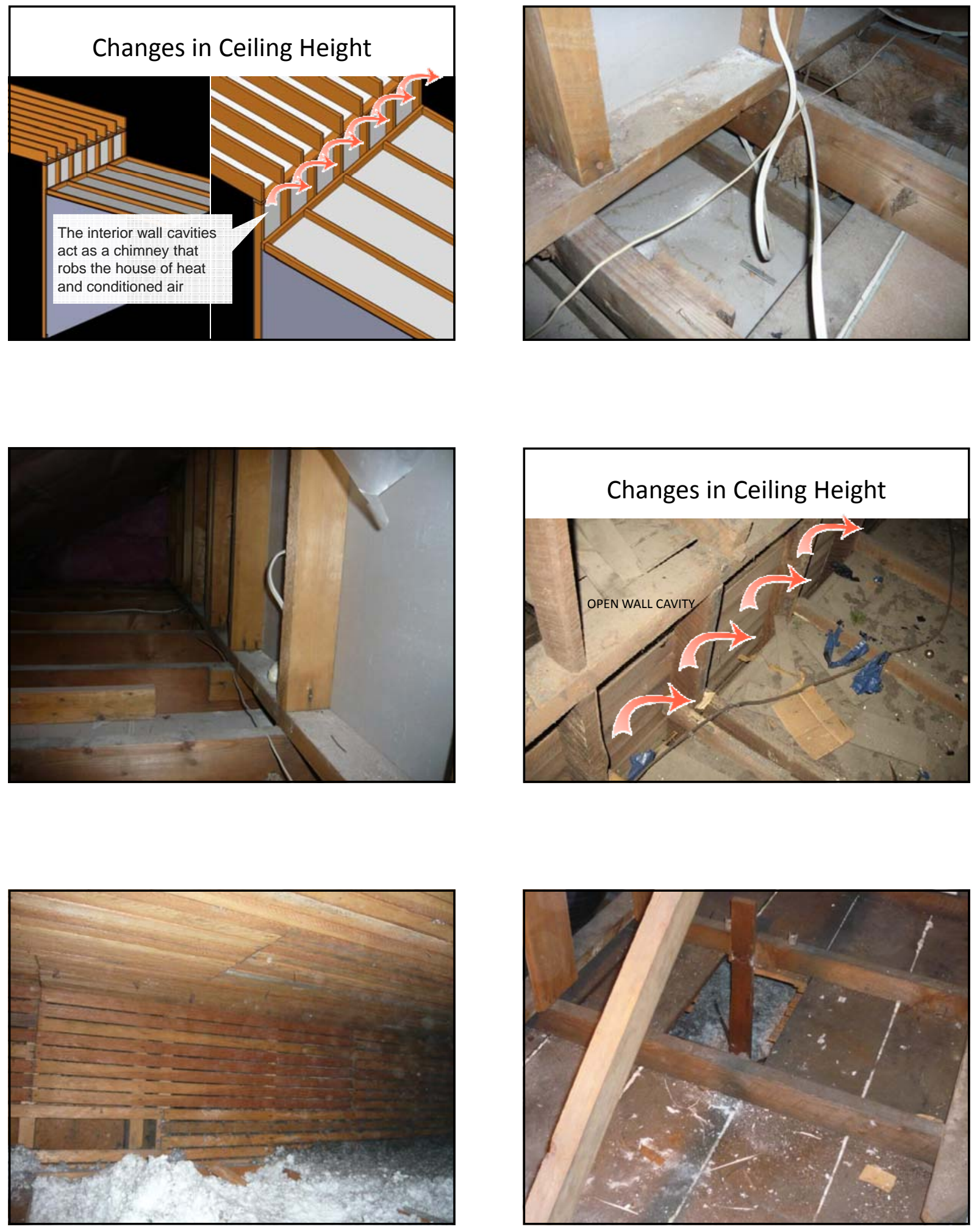

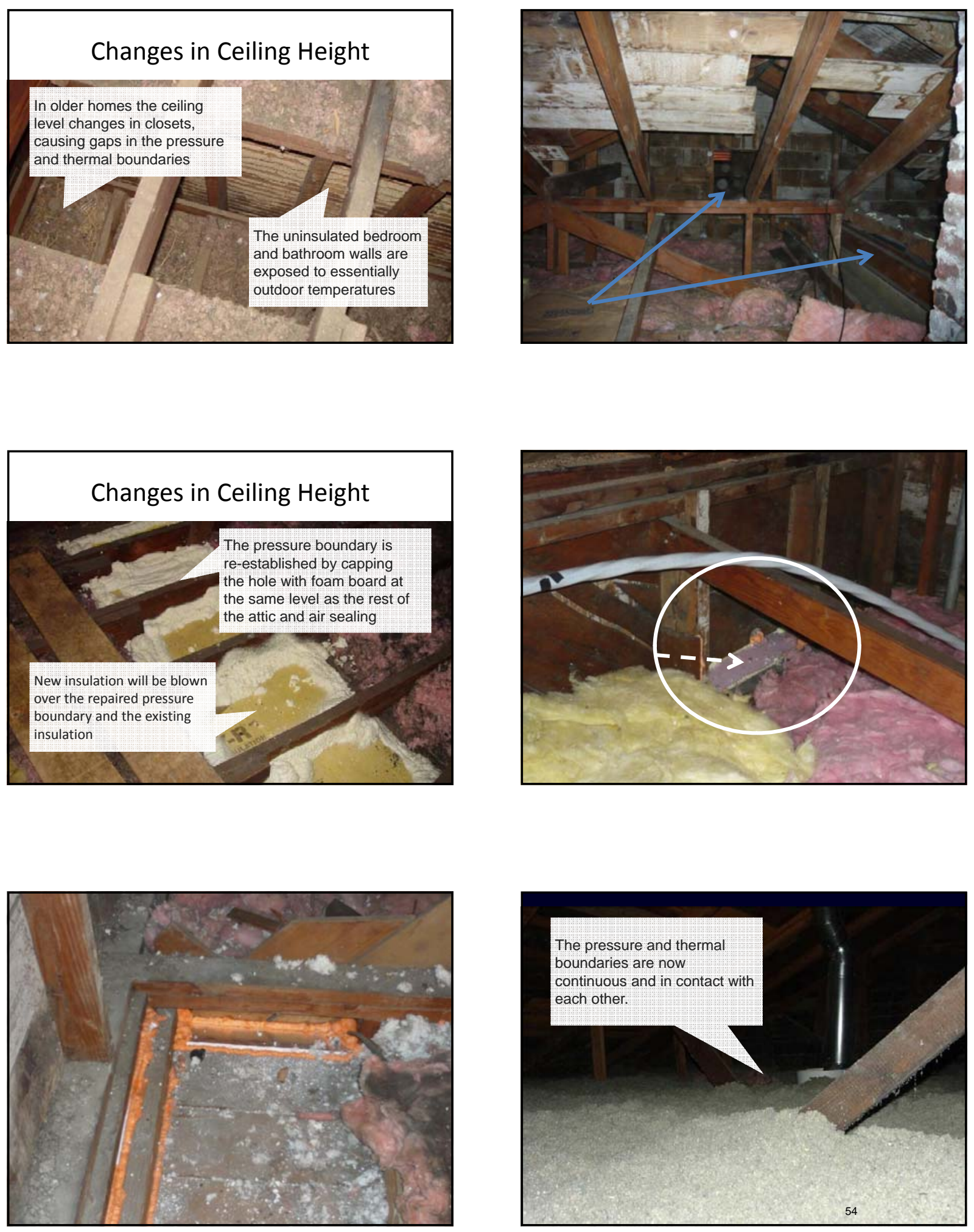

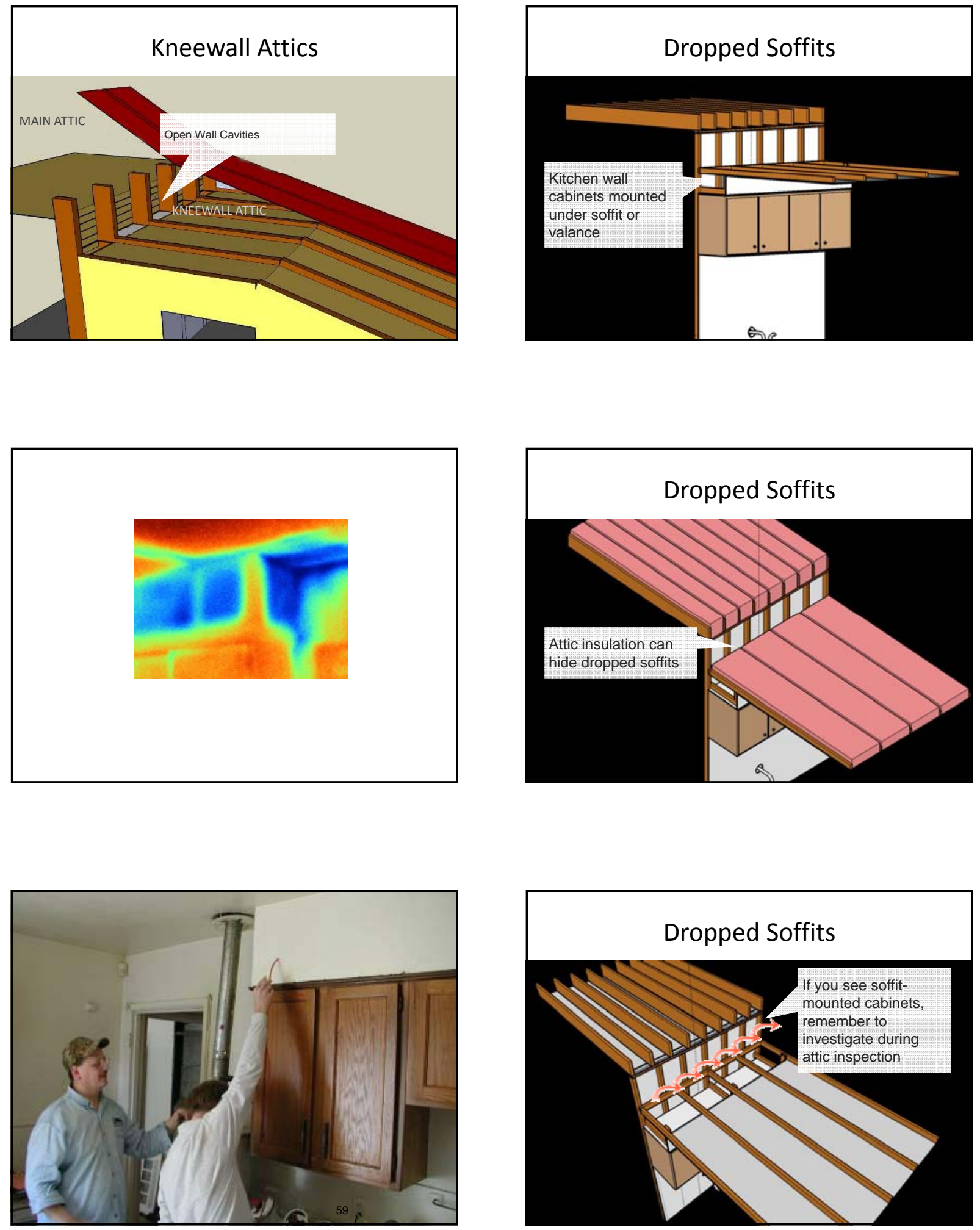

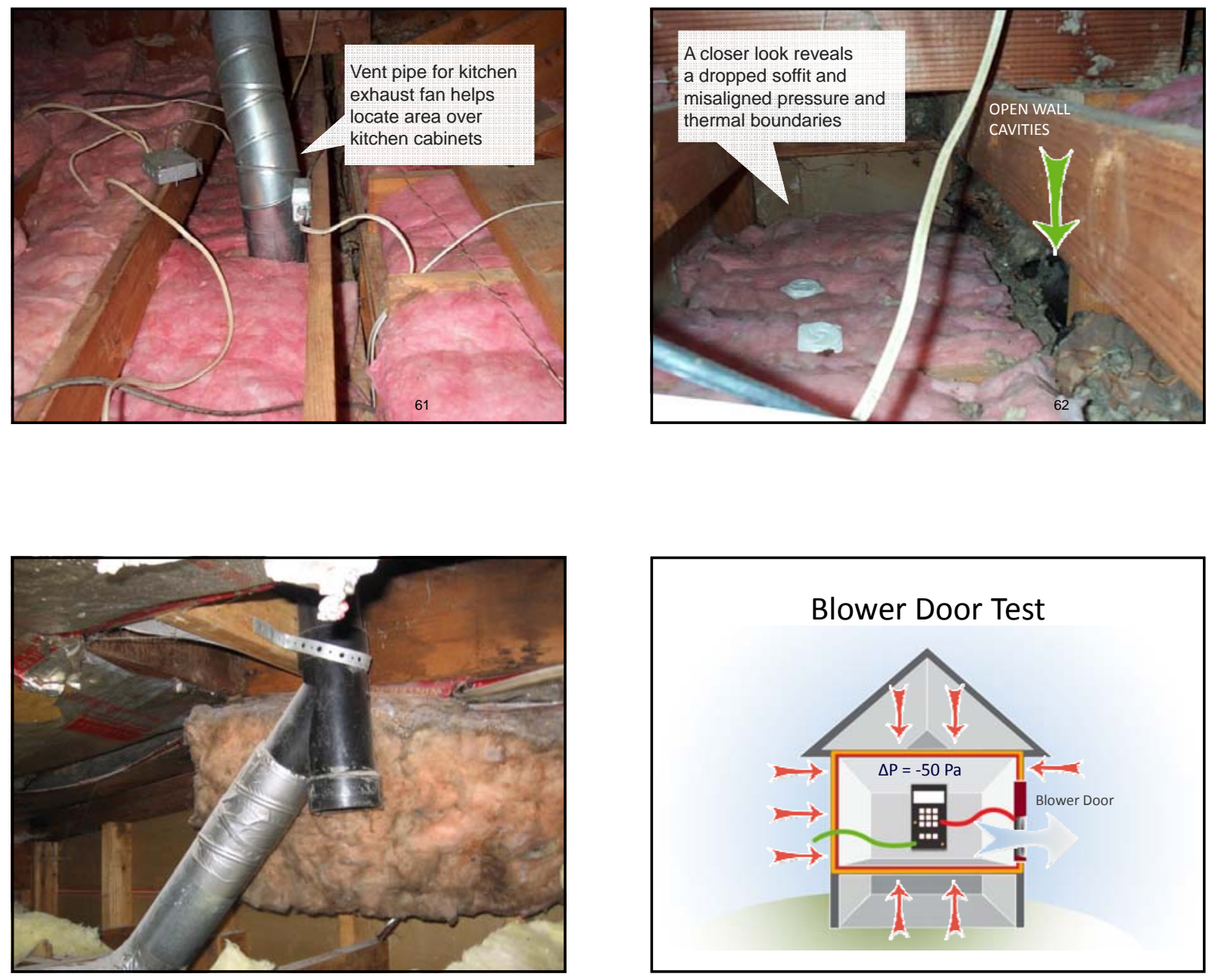

\section{Zone Pressure Diagnostics}

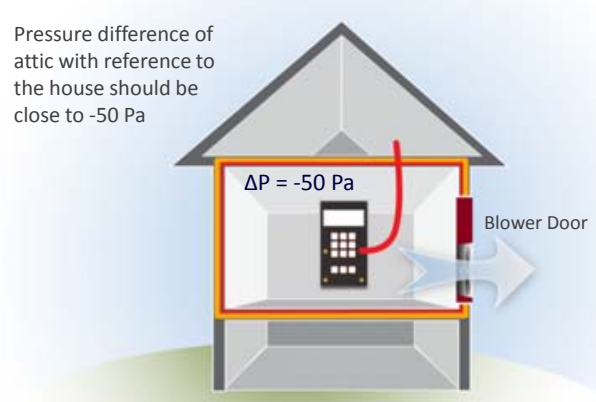

\section{Zone Pressure Diagnostics}

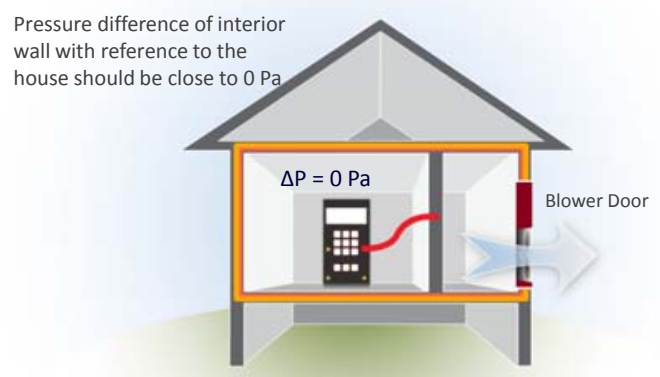



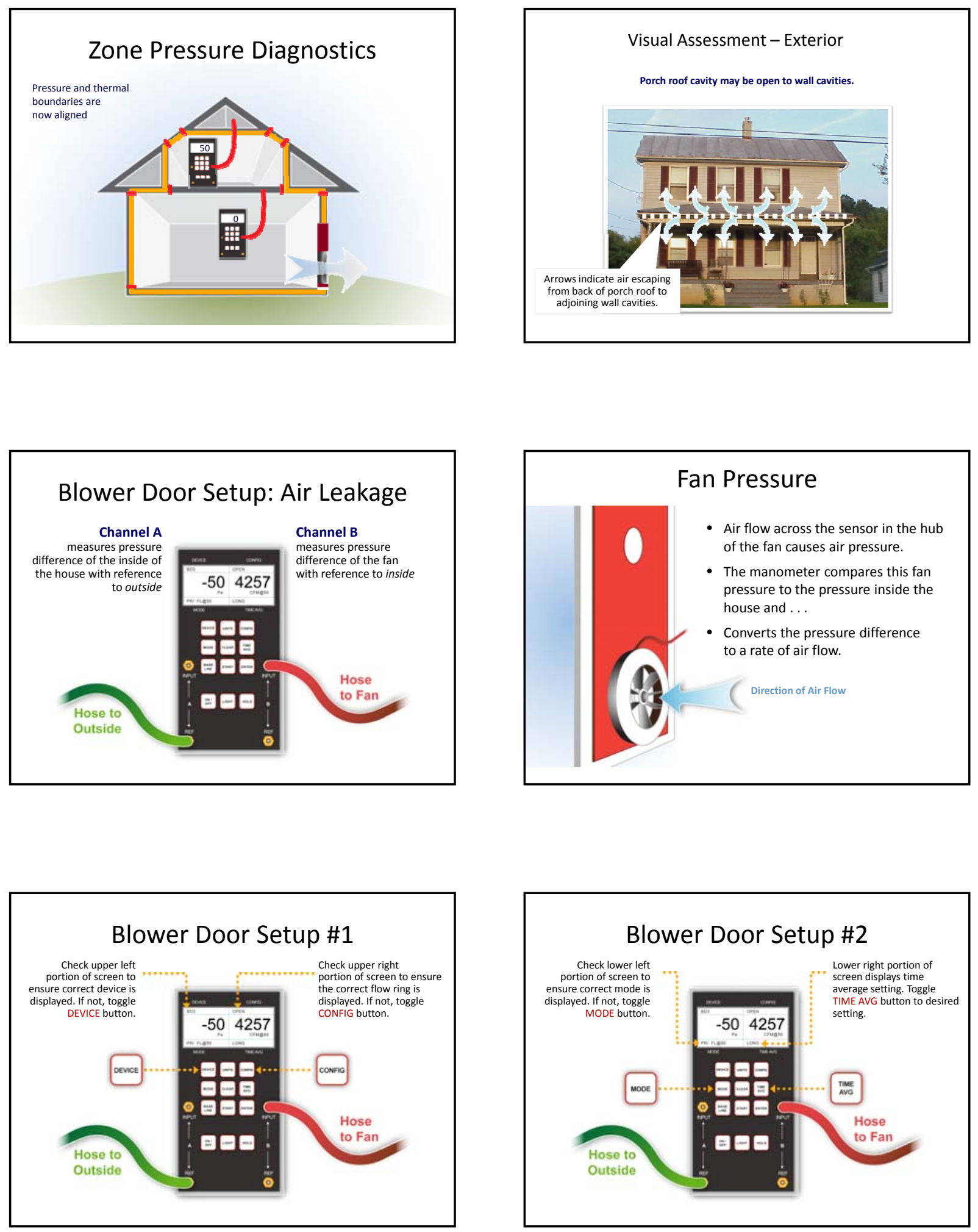

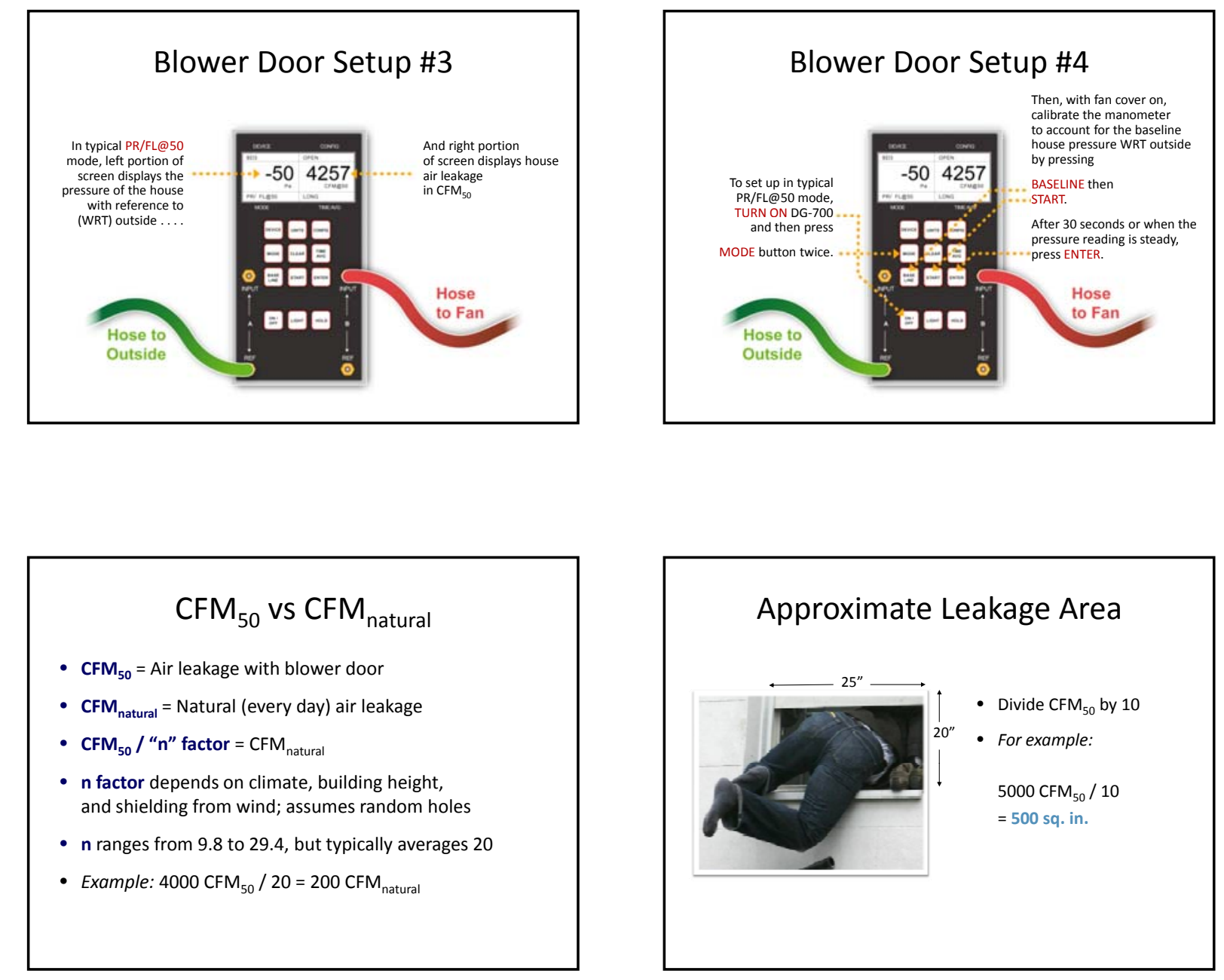

\section{Air Changes per Hour}

Air Changes per Hour at 50 Pascals $\left(\mathrm{ACH}_{50}\right)$

- $4000 \mathrm{CFM}_{50}$ is leaky for a small house, but may be pretty tight for a larger house.

- $\mathrm{ACH}_{50}$ takes the size of the house into account.

- $\mathrm{CFM}_{50} \times 60 \mathrm{~min} / \mathrm{hr} \div$ house volume $=\mathbf{A C H}_{50}$

- New Houses: $\mathrm{ACH}_{50}=5$ to 10

- Older Houses: $\mathrm{ACH}_{50}=11$ to 15

- Some weatherization-eligible houses have $\mathrm{ACH}_{50}$ up to 30 .

\section{Air Changes per Hour}

Air Changes per Hour at 50 Pascals $\left(\mathrm{ACH}_{50}\right)$

- House volume $=$ length $\mathrm{x}$ width $\mathrm{x}$ height

- Conditioned space only

- Example:

- House dimensions:

$40^{\prime}$ long, $28^{\prime}$ wide, $8^{\prime}$ high

- Blower door reading $=4500 \mathrm{CFM}_{50}$

- $\mathbf{A C H}_{50}=\mathrm{CFM}_{50} \times 60 \mathrm{~min} / \mathrm{hr} \div$ house volume
$=4500 \times 60 \div(40 \times 28 \times 8)$
$=4500 \times 60 \div 8960=30 \mathrm{ACH}_{50}$ 


\section{Minimum Ventilation Requirement}

Minimum Ventilation Requirement (MVR)

- Also called Building Tightness Limit (BTL).

- Amount of ventilation for adequate indoor air quality.

- If blower door reading is below MVR, mechanical ventilation must be added.

- MVR can be computed with:

- ASHRAE 62.1 (also written as 62.1989)

- ASHRAE 62.2

- Measure flow of existing mechanical ventilation.

\section{Zonal Pressure Diagnostics \#1}

Conduct zonal pressure diagnostics and interpret results to determine:

- Location and effectiveness of the air barrier

-Alignment of air barrier and thermal boundary

-If the pressure of the main house WRT garage indicates

serious leaks between the two zones

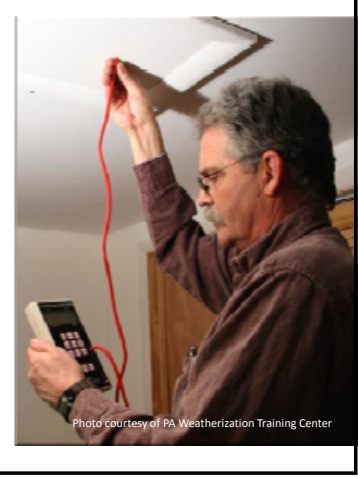

\section{Zone Pressure Diagnostics \#3}

Pressure difference of interior wall with reference to the house should be close to 0 $\mathrm{Pa}$.

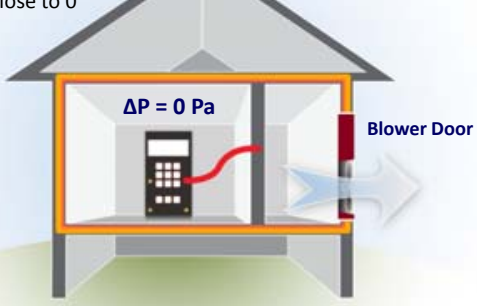

Where Is the Air Barrier?

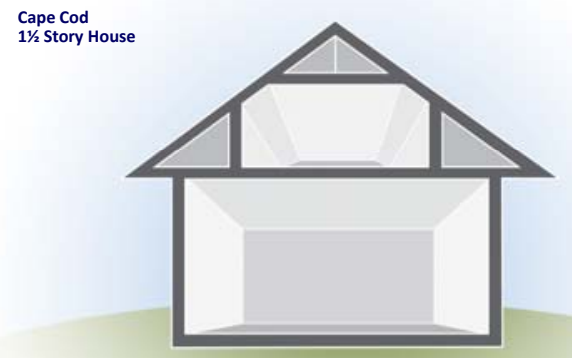

\section{Where Is the Air Barrier?}

Pressure difference of the floor cavity with reference to

the house should be

$0 \mathrm{~Pa}$. But, is it?

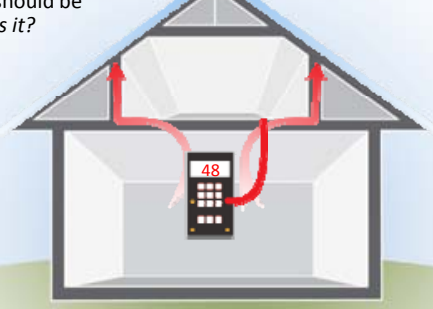




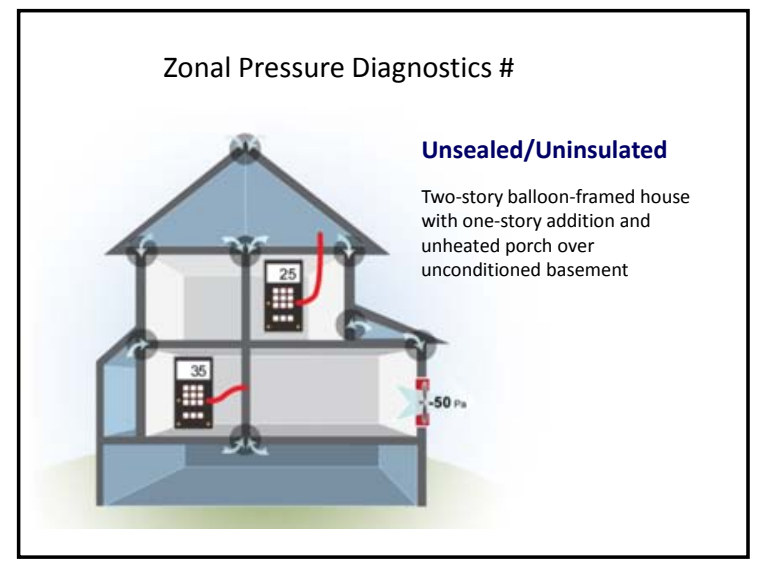

Zonal Pressure Diagnostics \#5
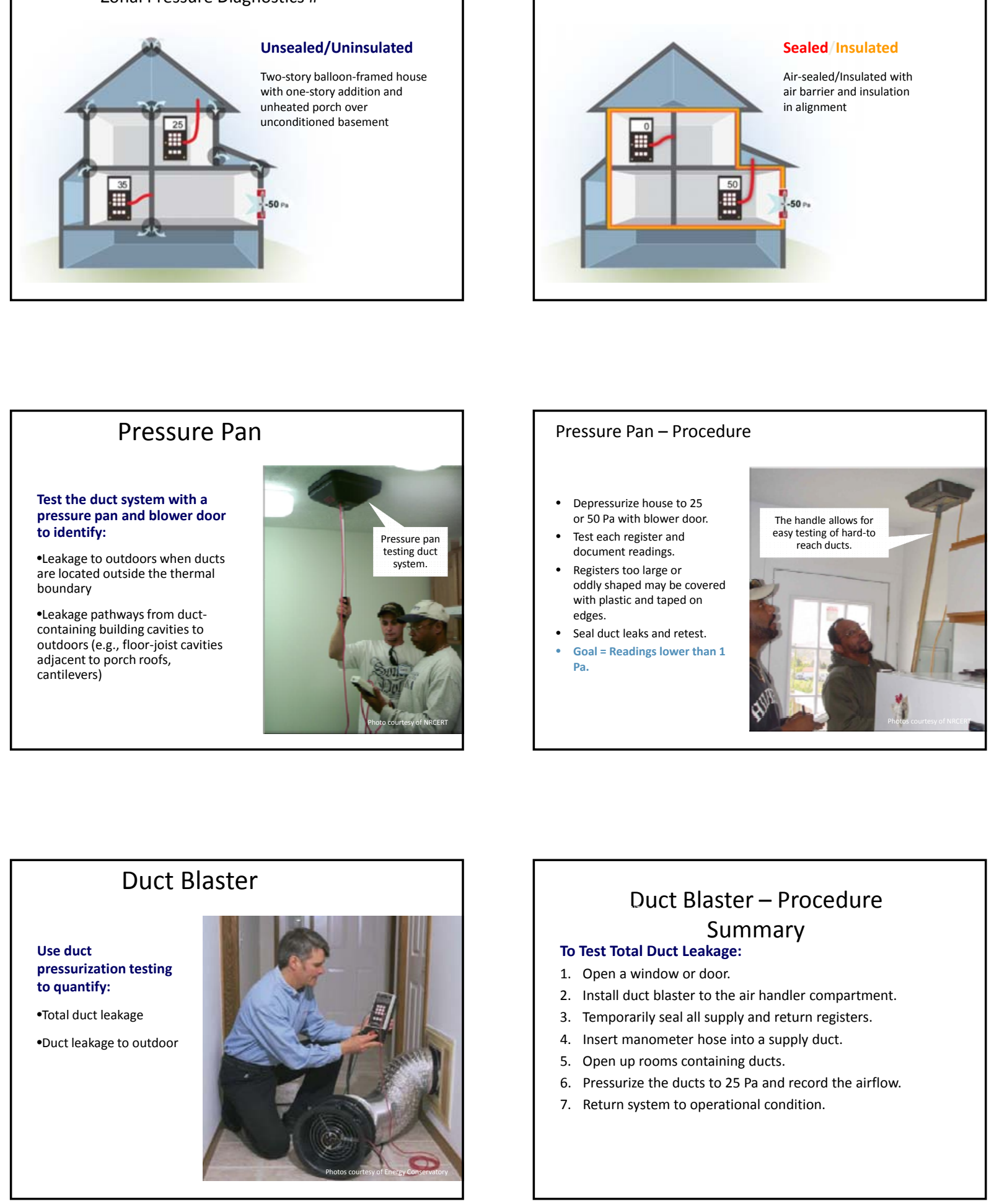


Duct Blaster - Procedure
Summary
To Test Duct Leakage to Outdoors:
1. Set up home in normal heating or cooling configuration; no
fires burning!
2. Set up blower door to pressurize the house.
3. Connect duct blower to air handler compartment and
manometer hose to air handler compartment.
4. Pressurize the ducts to 25 Pa.
5. Pressurize the house until the pressure difference of the
house WRT the duct is 0 Pa.
6. Record the airflow at the duct blower.

\section{Dominant Duct Leakage}

Conduct a dominant duct leakage test to determine if the supply or return ducts have more leaks to outside.
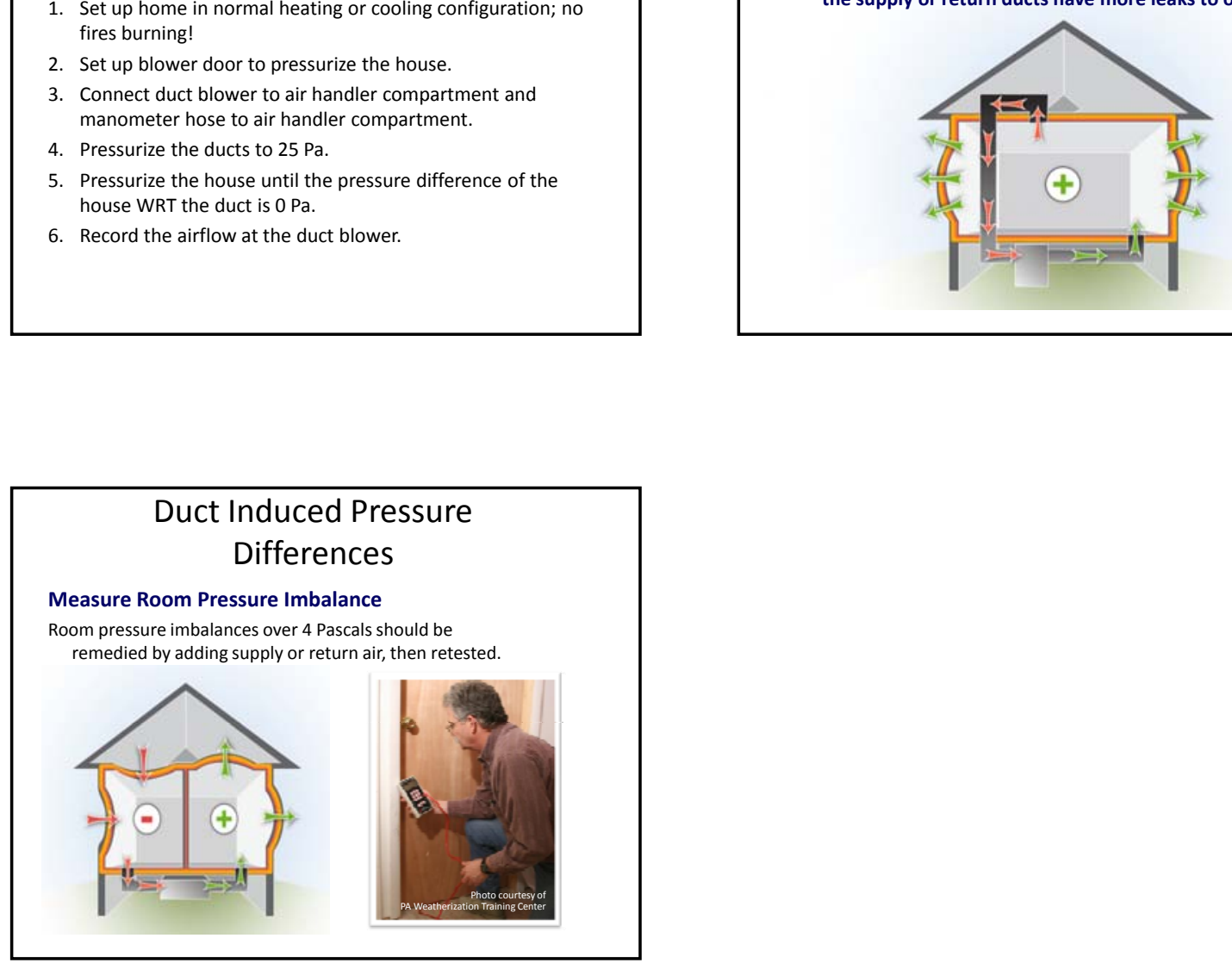

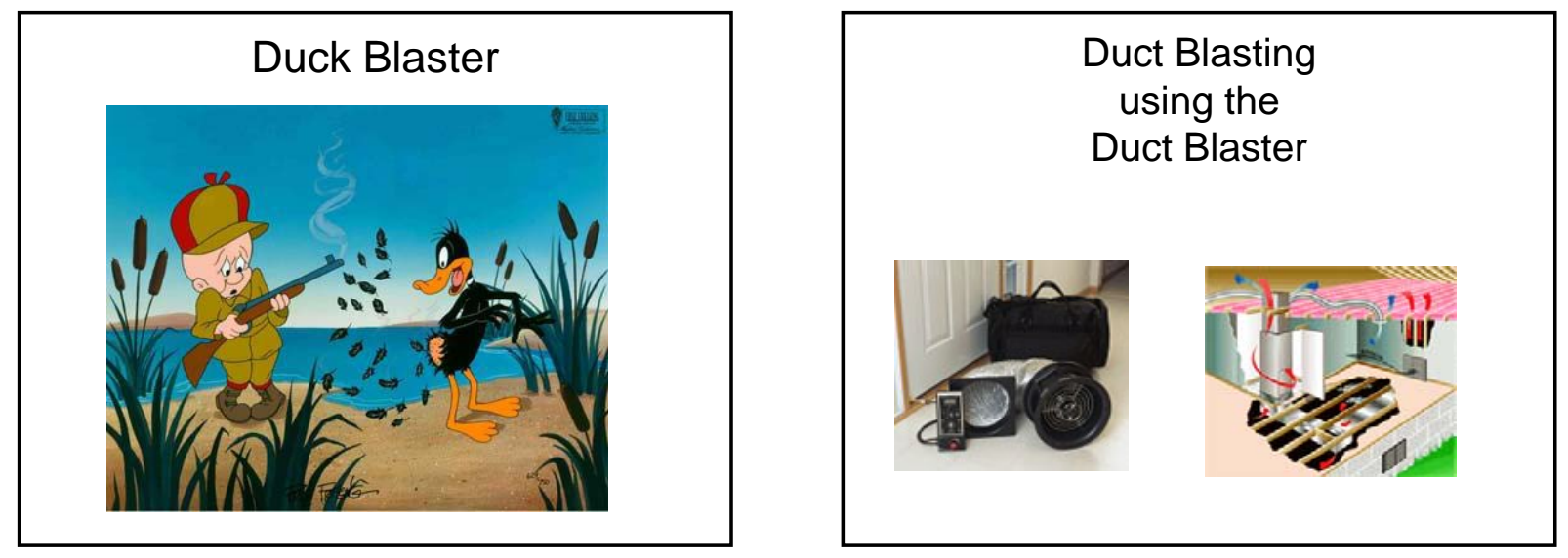

\section{Why Test?}

- Troubleshooting comfort and performance complaints

- Measure effectiveness of duct sealing

- Estimate annual HVAC system losses from duct leakage

- Certifying compliance

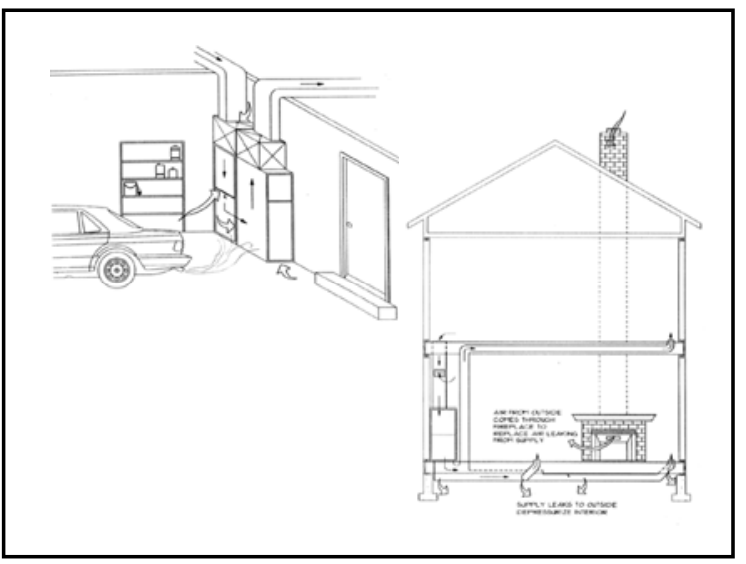

\section{Where Does Leakage Occur?}

- Poor fitting joints and seams

- Disconnected or partially disconnected boot connections

- Holes in duct runs

- Use of building cavities for ducting

- "Platform" returns

- Air handler doors, filter trays

- Failed tape joints 


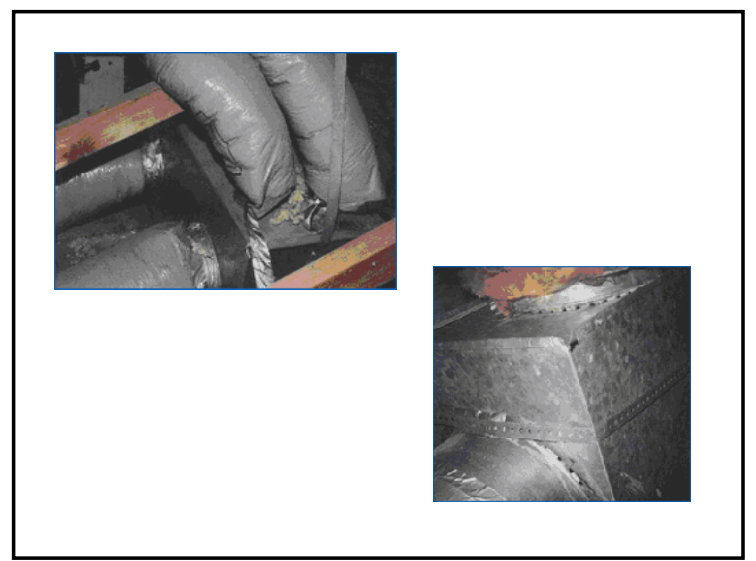

\section{A summary of 19 separate duct leakage studies indicates that the average annual energy savings potential in a typical home is around $17 \%$}

\section{Fan Stuff}

- The duct blaster fan is not rated for continuous operation- maximum 2 hours continuous operation.

- Test @ $25 \mathrm{~Pa}$ (0.10 inches w.c.)

- Readings are normally taken in cfm

\section{Where to Measure Duct Pressures}

- Main supply trunk approximately midway between the duct blaster and the supply registers / grilles

- Supply plenum if the duct blaster is installed at the central return

- A supply register / grille

\section{Measuring Pressures}

If the duct work is relatively tight, the duct pressures will be uniform and provide consistent results.

If the duct work is leaky, there may be large pressure differences from one part of the system to another, test results will vary depending on pressure measuring locations. 


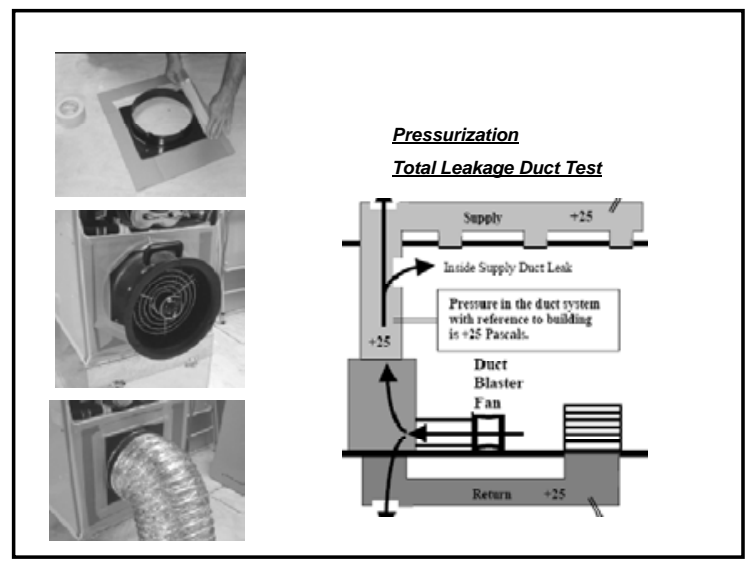

\section{Preparing the Building}

Open a door between the building and outside to prevent changes in building pressure when the duct blaster fan is running

\section{Multi-Point Test}

Take 5 different test pressures;

35, 30, 25, 20 \& 15 Pascals

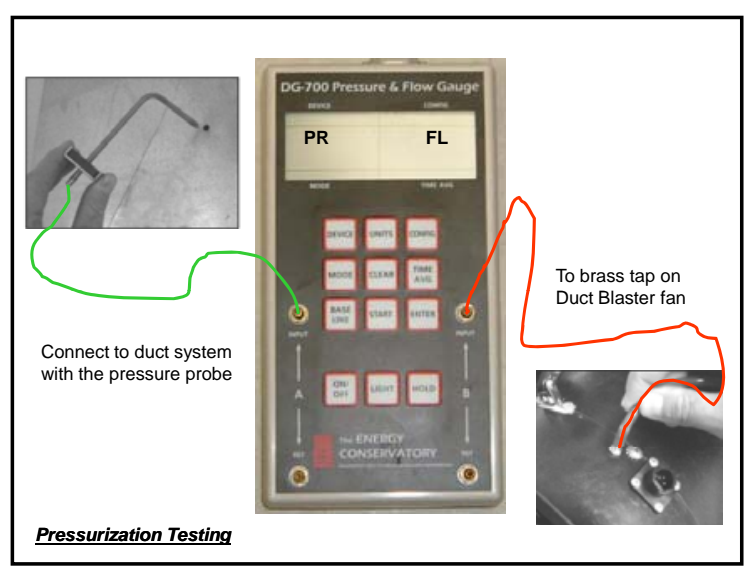

DG-700 Multi-Point

Turn on the gauge,

Press the MODE button once, this will put the gauge in the PR / FL mode.

In this set up, Channel A will measure test pressure while simultaneously measuring air flow from the fan on Channel B

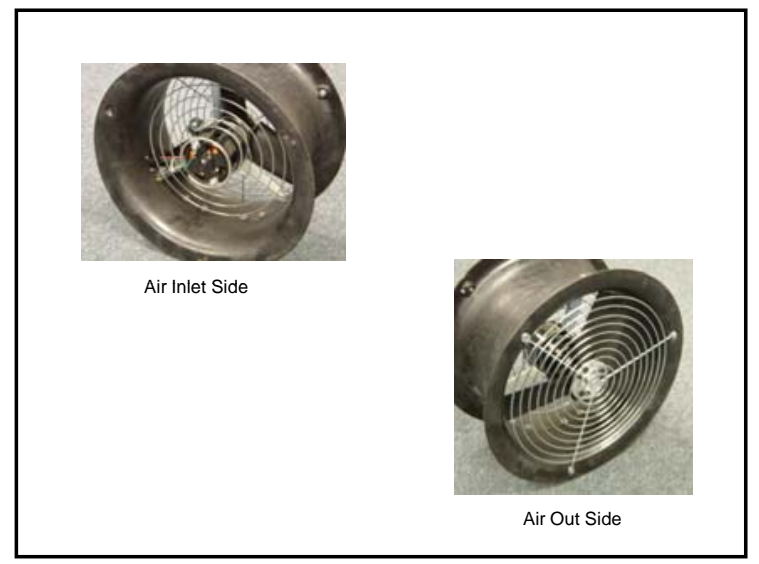


The greatest accuracy in fan flow readings will always be achieved by installing the flow ring with the smallest opening area, while still providing the necessary fan flow to pressurize the duct system.

\begin{tabular}{|c|c|c|}
\hline Flow Ring Configuration & Flow Range (CFM) & Minimum Fan Pressure (Pa) \\
\hline Open (no Flow Ring) $^{*}$ & $1,500-600$ & $25 \mathrm{~Pa}$ \\
\hline Ring 1 & $800-225$ & $25 \mathrm{~Pa}$ \\
\hline Ring 2 & $300-90$ & $25 \mathrm{~Pa}$ \\
\hline Ring 3 & $125-20$ & $10 \mathrm{~Pa}$ \\
\hline
\end{tabular}

When conducting a depressurization test the exhaust side of the duct blaster fan will be open to the room, and the inlet side of the fan must be connected to the flexible extension duct,

The flow conditioner and one of the flow rings must always be installed when doing a depressurization test,
When installing any of the flow rings, place the ring against the inlet of the fan so the outer edges of the ring roughly line up.

Be sure the nozzle located in the middle of the ring is pointed inward toward the fan motor.

\section{Test Results}

- Total leakage at 25 Pascals

- Duct leakage as a \% of total system airflow

- Duct leakage as a Percent of floor area.

\section{ASHRAE 62.2-2004 Addendum f (6.5)}

When an occupiable space adjoins a garage, the design must prevent migration of contaminants to the adjoining space.

HVAC systems that include air handlers or return ducts located in garages shall have return or total air leakage of no more than $50 \mathrm{cfm}$ using ASTM E1-15542003 or equivalent.

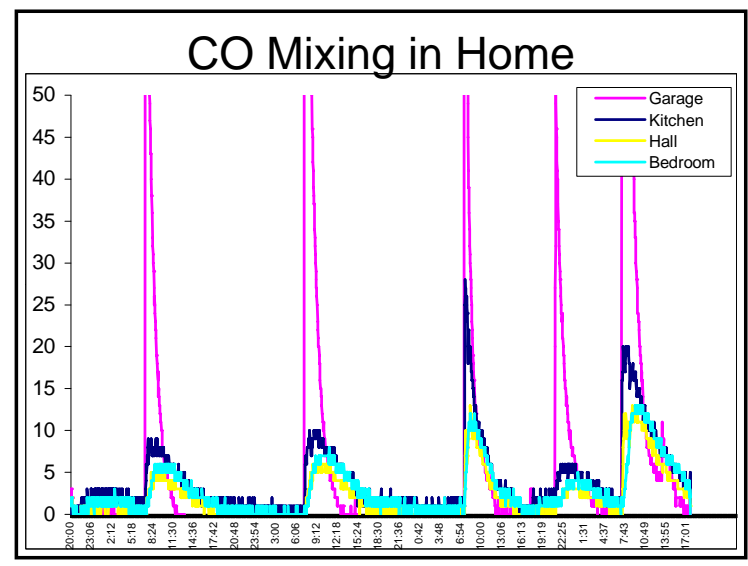



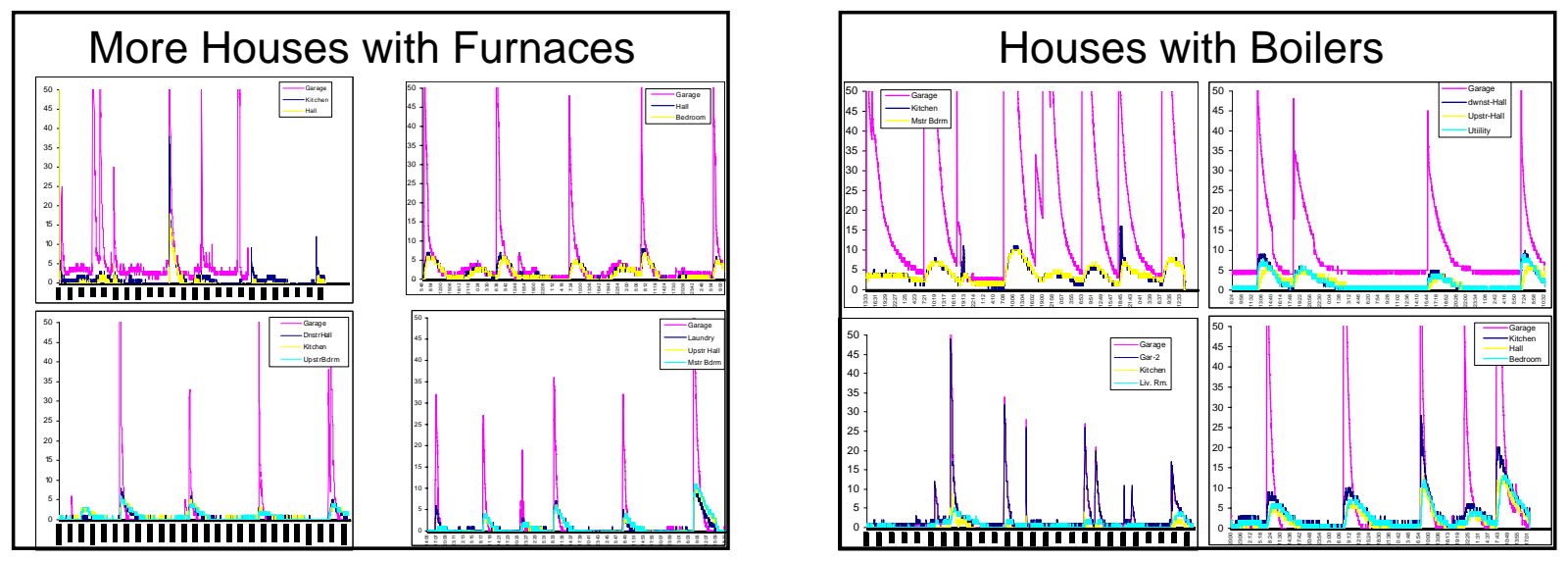

\section{CO Monitoring Study Conclusions (12 houses)}

- CO from car starts entered 11 out of 12 homes. House CO peaked within 4 minutes.

- CO transfer was particularly high with furnace in the garage

- Household exposure ranged from 0 to $115 \%$ of EPA limit. 4 homes exceeded $60 \%$ of EPA limit.

- CO dispersed rapidly once inside the home

- The same mechanism for CO transfer likely to carry other pollutants into the house.

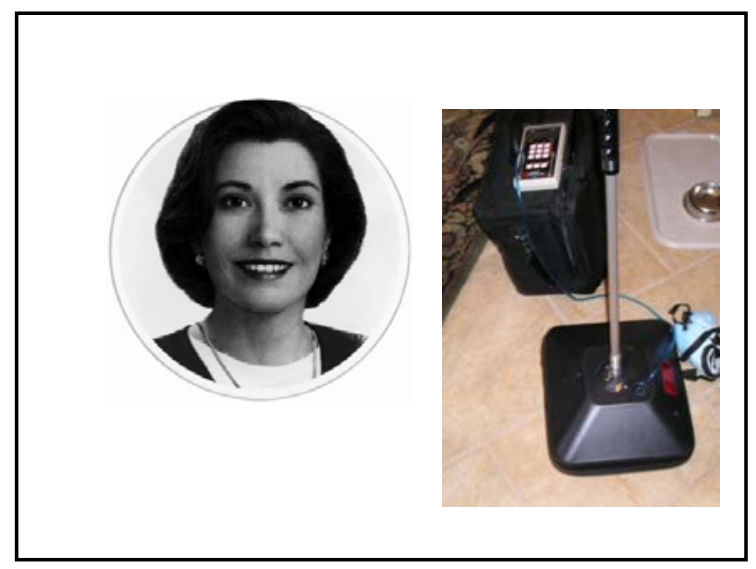

\section{Using a Pressure Pan}

- Pressure pan testing involves placing a pan over each register or grill, one at a time.

- Pressure pans do not directly measure leakage rates.

- We're looking for quick identification of major leakage sites. 


\section{The Reason}

- Pressure pan testing is used to measure the pressure between the house and a duct run during a blower door test.

- This pressure reading can be used to estimate the extent to which a particular duct run is "not inside".

\section{Taking Readings}

1. Starting at the blower work clockwise through the house temporarily sealing off the register and measure the pressure.

2. To temporarily seal off registers you can use masking tape or paper.

3. Once you have taken the pressure reading, remove the temporary seal before proceeding to the next register.

\section{Field Procedure 3}

- Turn on the blower door and pressurize or depressurize the house by $50 \mathrm{~Pa}$ with respect to outside.

- Set up the gauge to measure pressure in Pascals on the pressure channel connected to the pan. The gauge should be set to use 1 second averages and 0.1 Pascal resolution.

\section{Field Procedure ${ }^{4}$}

- With the blower door running firmly place the pressure pan completely over each register or grill.

- Wait for the reading to stabilize \& record the pressure.

- Repeat the test for each register and grill in the house. 
Two types of combustion air systems

$>$ OPEN - uses surrounding air for combustion and dilution

$>$ SEALED - Brings in outside air for combustion and dilution

\section{Open Combustion}

Systems compete for air with other

\section{household exhaust} appliances.

\section{Three types of chimney draft:}

$>$ Naturally Aspirating - relies on buoyancy of the hot flue gases to rise in the chimney

$>$ Induced-Maintains negative pressure in the chimney. Fan often at point of exit of the building.

Forced - Maintains a positive pressure in the chimney. Chimney must be air tight.

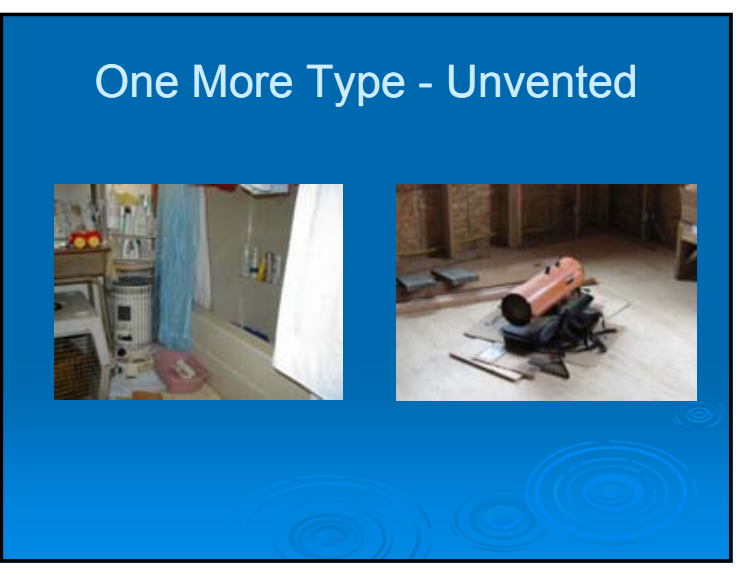

AHFC Pressure Decrease Limits

$>$ Category l: $\quad 5 \mathrm{~Pa}$

$>$ Takes combustion air and chimney draft dilution air from within a building, is installed with a draft hood, draft regulator, or other means of allowing for regulation of dilution air, and depends upon natural draft to vent products of combustion to the outdoors. 

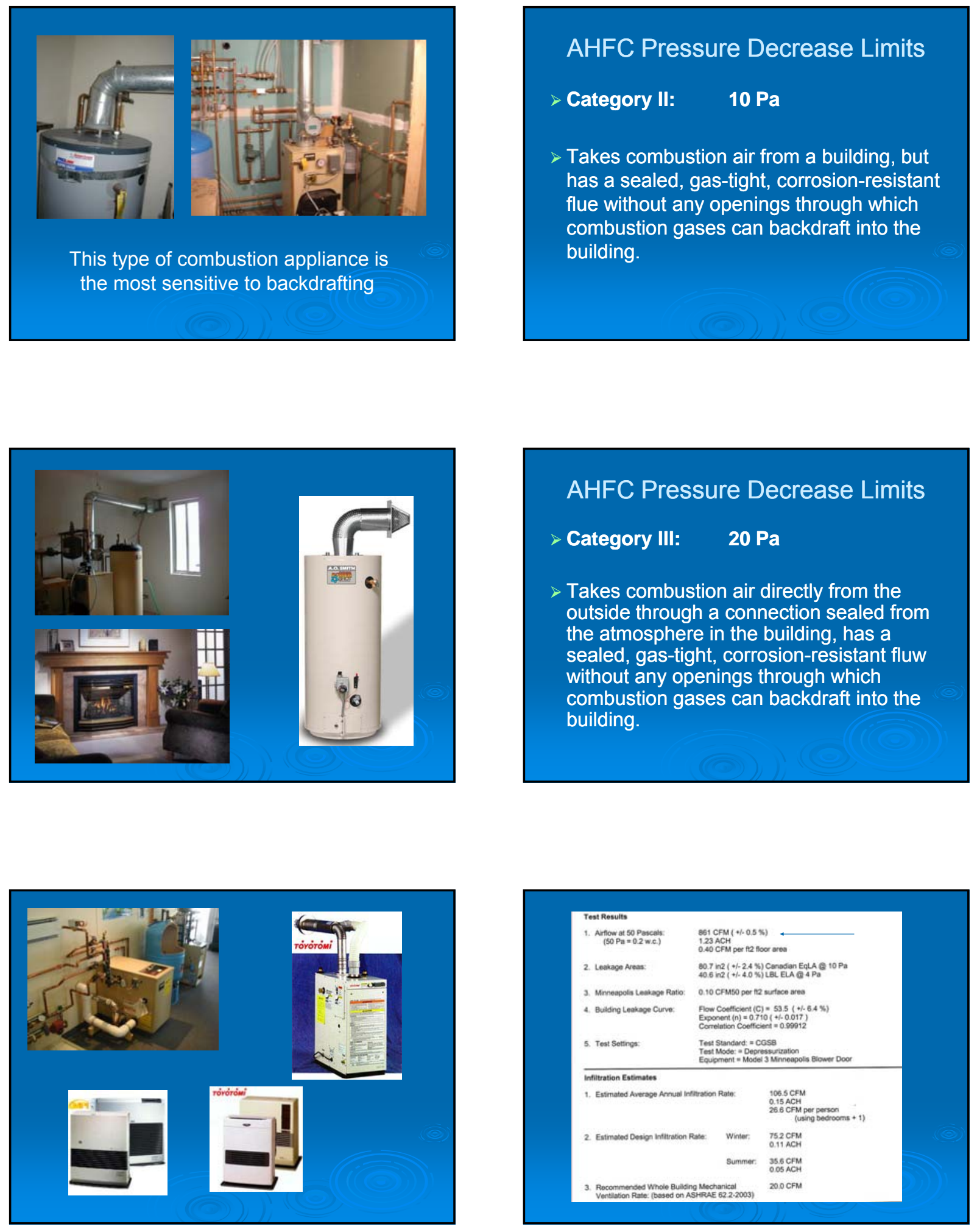


\begin{tabular}{|c|c|c|}
\hline \multicolumn{3}{|l|}{ Test Results } \\
\hline 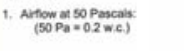 & \multicolumn{2}{|c|}{ 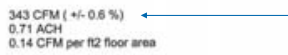 } \\
\hline 2. Looknge Avess: & \multicolumn{2}{|c|}{ 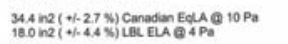 } \\
\hline 3. Mnneapolis Leaboge Ratio: & \multicolumn{2}{|c|}{0.05 CFMSO per ra surtoce arrea } \\
\hline 4. Butang Leaverop Cunve: & \multicolumn{2}{|c|}{ 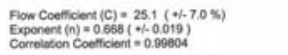 } \\
\hline 5. Test Seongs: & \multicolumn{2}{|c|}{ 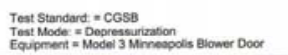 } \\
\hline \multicolumn{3}{|l|}{ Infiltration Estimates } \\
\hline \multicolumn{2}{|c|}{ 1. Eatinatod Average Annual inflitration Ratio: } & 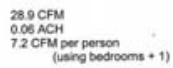 \\
\hline \multirow[t]{2}{*}{ 2. Eatimated Design influration $R$} & Winter: & $\begin{array}{l}33.3 \mathrm{CFM} \\
0.07 \mathrm{ACH}\end{array}$ \\
\hline & Summer: & $\begin{array}{l}15.8 \mathrm{CFM} \\
0.03 \mathrm{ACH}\end{array}$ \\
\hline \multicolumn{2}{|c|}{ 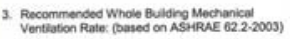 } & $\mathrm{SACFM}$ \\
\hline
\end{tabular}

\begin{tabular}{|lc|}
\hline APPLIANCE & \\
\hline \multicolumn{2}{|c|}{ EXPECTED CFM EXHAUST FLOW } \\
\hline down draft cooktop exhaust fan & $300+$ \\
clothes dryer & $150-240$ \\
central whole house exhaust & $100+$ \\
central vacuum & 100 \\
master bathroom exhaust fan & $50+$ \\
other bathroom exhaust fans & $35+$ \\
"balanced" HRV type system & $?$ check \\
fireplace & 250 \\
kitchen range exhaust fan & 150 \\
old, open front wood fireplace & 300 \\
old, wood stove (door ports) & 65 \\
airtight wood stove & 25 \\
natural draft water heater & 30 \\
natural draft boiler or furnace & 125 \\
power vented boiler or furnace & 25 \\
\hline
\end{tabular}

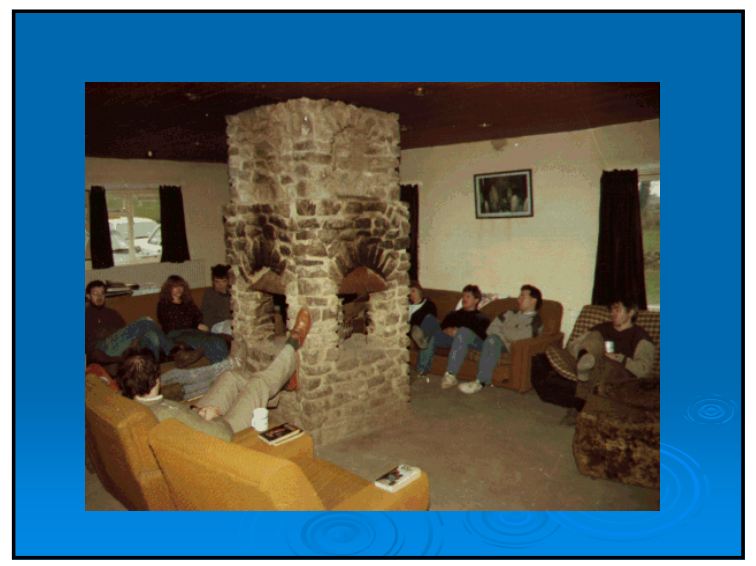

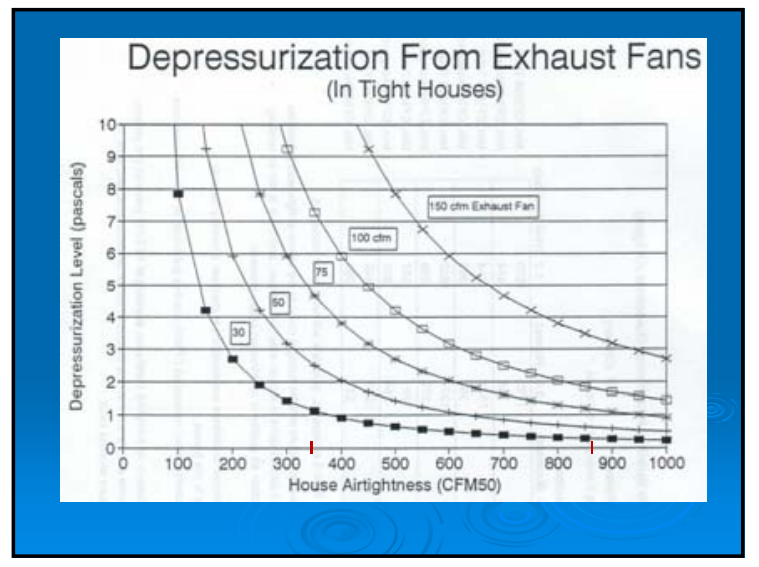
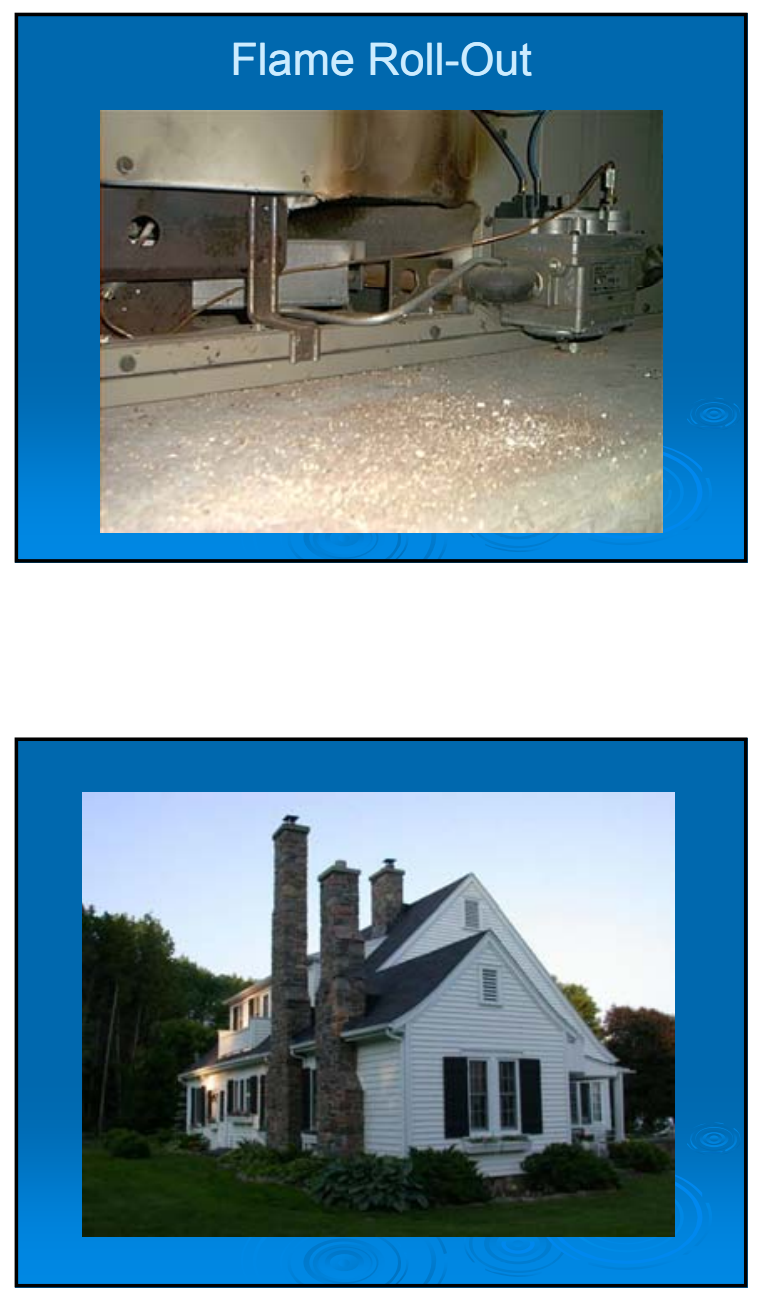

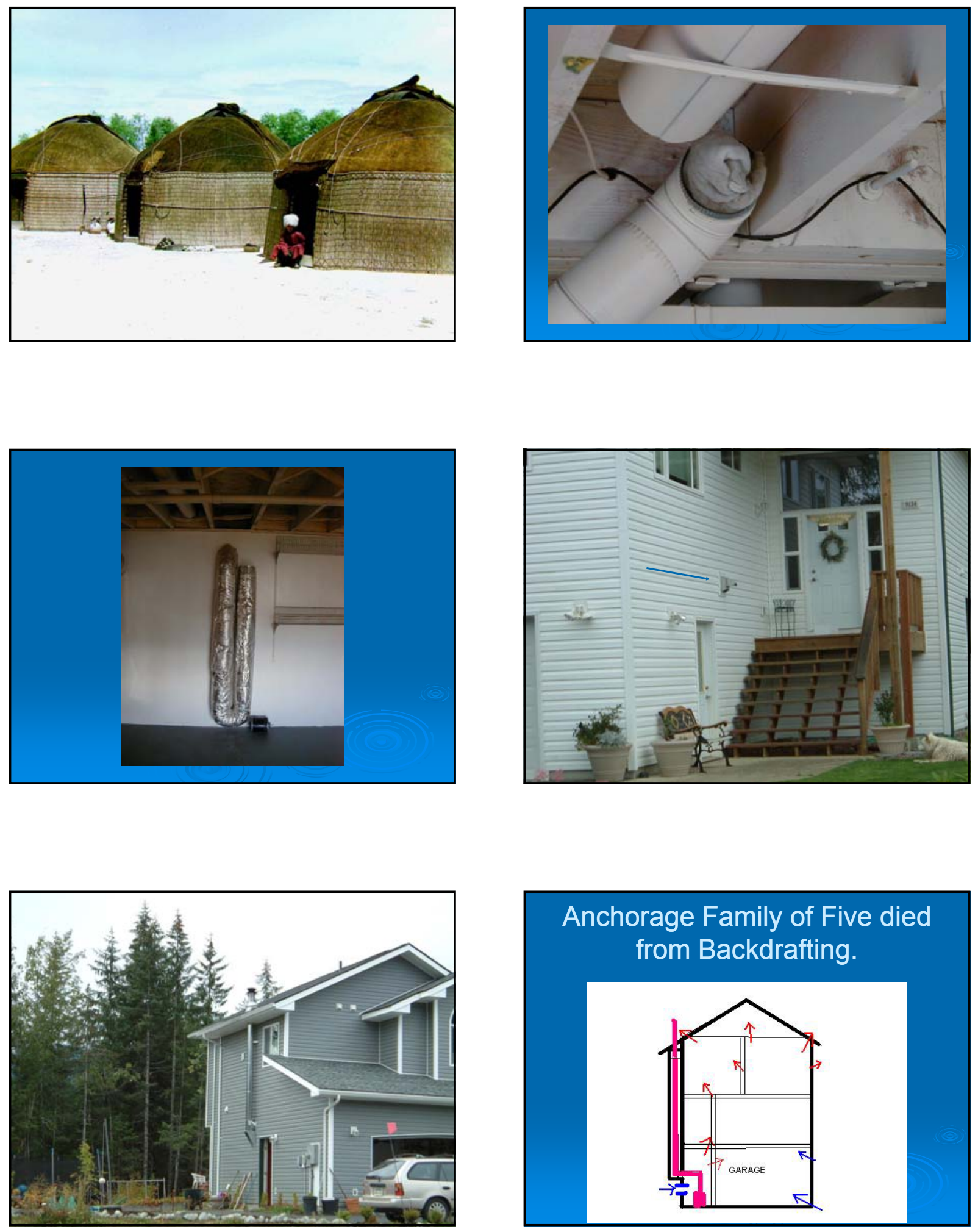

Anchorage Family of Five died from Backdrafting.

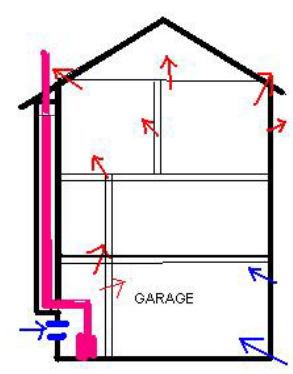



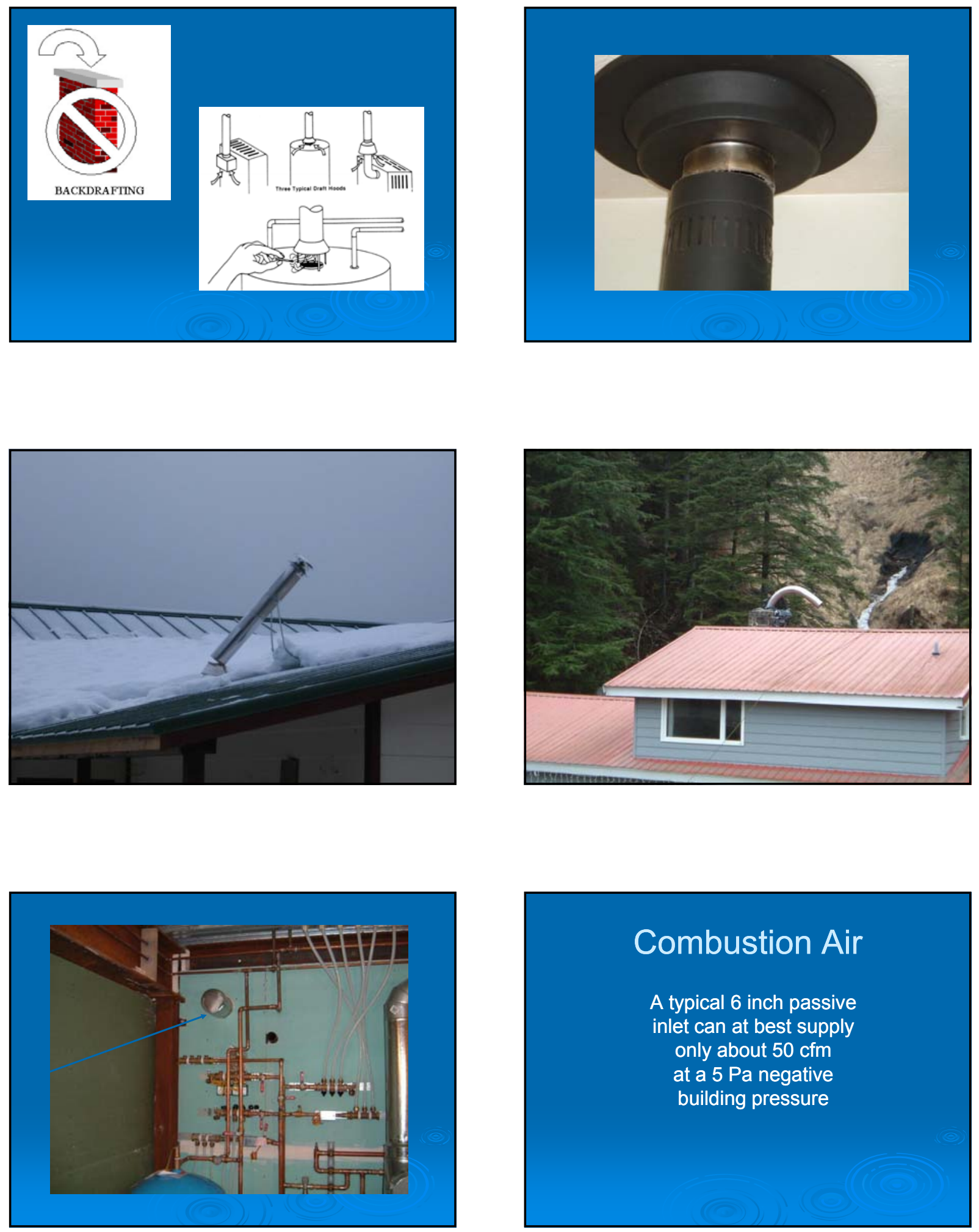

\section{Combustion Air}

A typical 6 inch passive inlet can at best supply only about $50 \mathrm{cfm}$ at a $5 \mathrm{~Pa}$ negative building pressure 

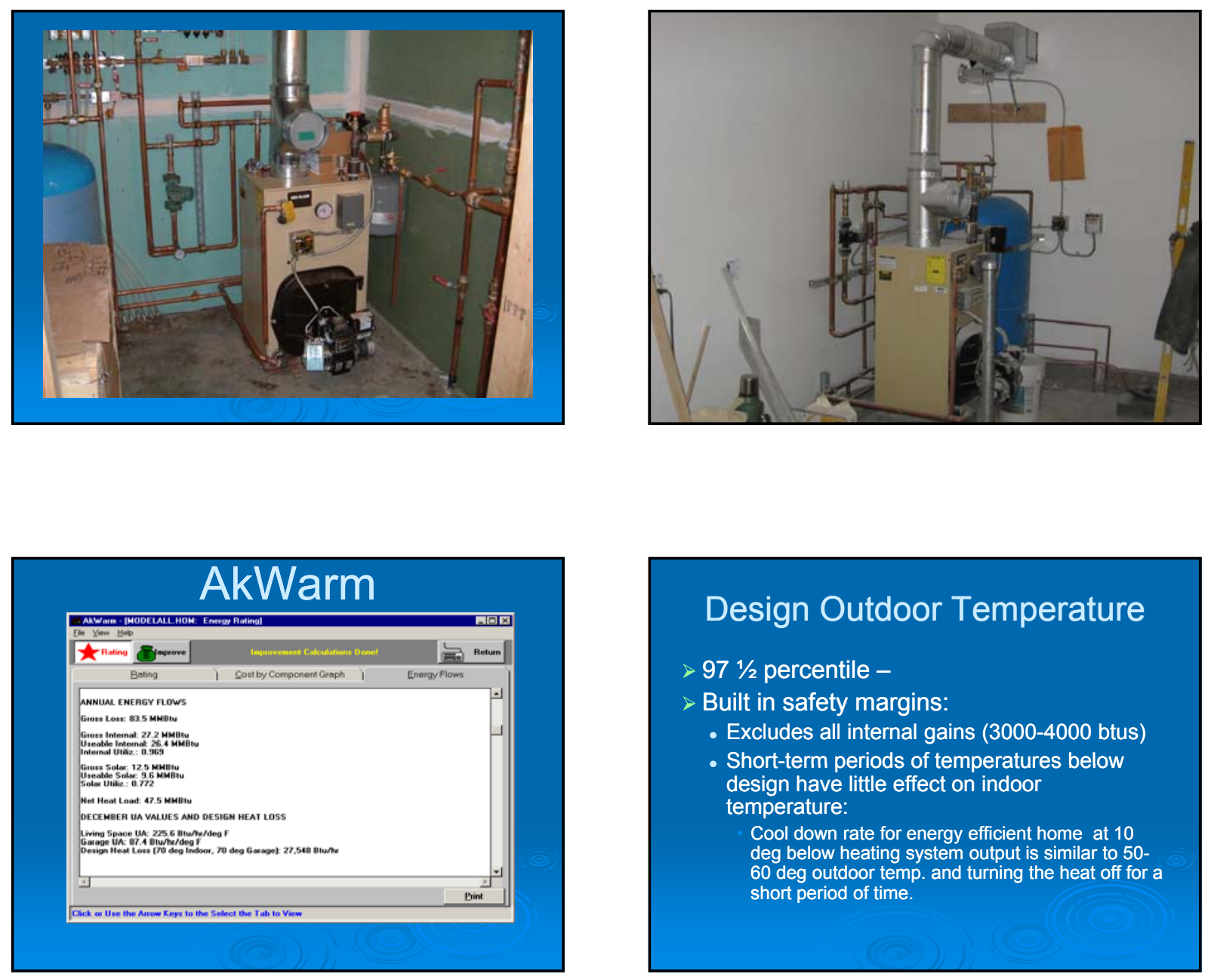

\section{Design Outdoor Temperature}

$>971 / 2$ percentile -

$>$ Built in safety margins:

- Excludes all internal gains (3000-4000 btus)

- Short-term periods of temperatures below design have little effect on indoor temperature:

Cool down rate for energy efficient home at 10 deg below heating system output is similar to 50 60 deg outdoor temp. and turning the heat off for a short period of time.

\section{Energy Efficient Homes}

$>$ Smaller heat load per square foot

- Typical 5 Star home in SE Alaska 1520/btu/sqft living space

- Zoning becomes less important - controlling the temperature becomes simpler

$>$ Smaller, simpler heating systems should off-set much of the cost of the energy efficiency improvements.

Houses today need $50 \%$ less heat than houses 20 years

$$
\text { ago, }
$$

so why have heating system sizes remain the same? 


\section{Domestic Water Heating}

$>$ Hot water demand requirements:

- Hot tub? Number of bath rooms, etc.

- Storage \& burner size - First Hour capacity

- Typical water heater operates 2 hours a day.

Separate water heating appliance or combined with space heating appliance

- Typical gas/oil tank type heater $(30,000-100,000$ btu)

- Indirect Water Heater off of boiler (output can equal boiler size)

- Combo system - Polaris $(100,000$ btu $)$
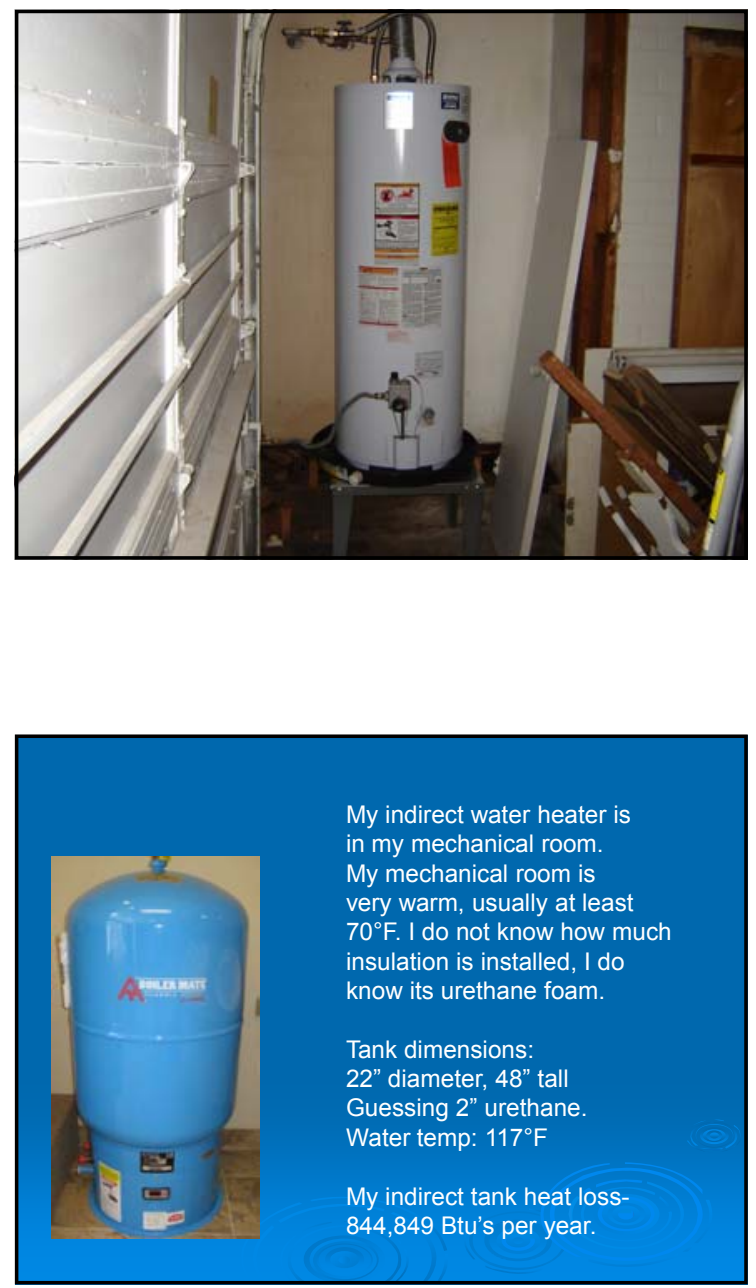
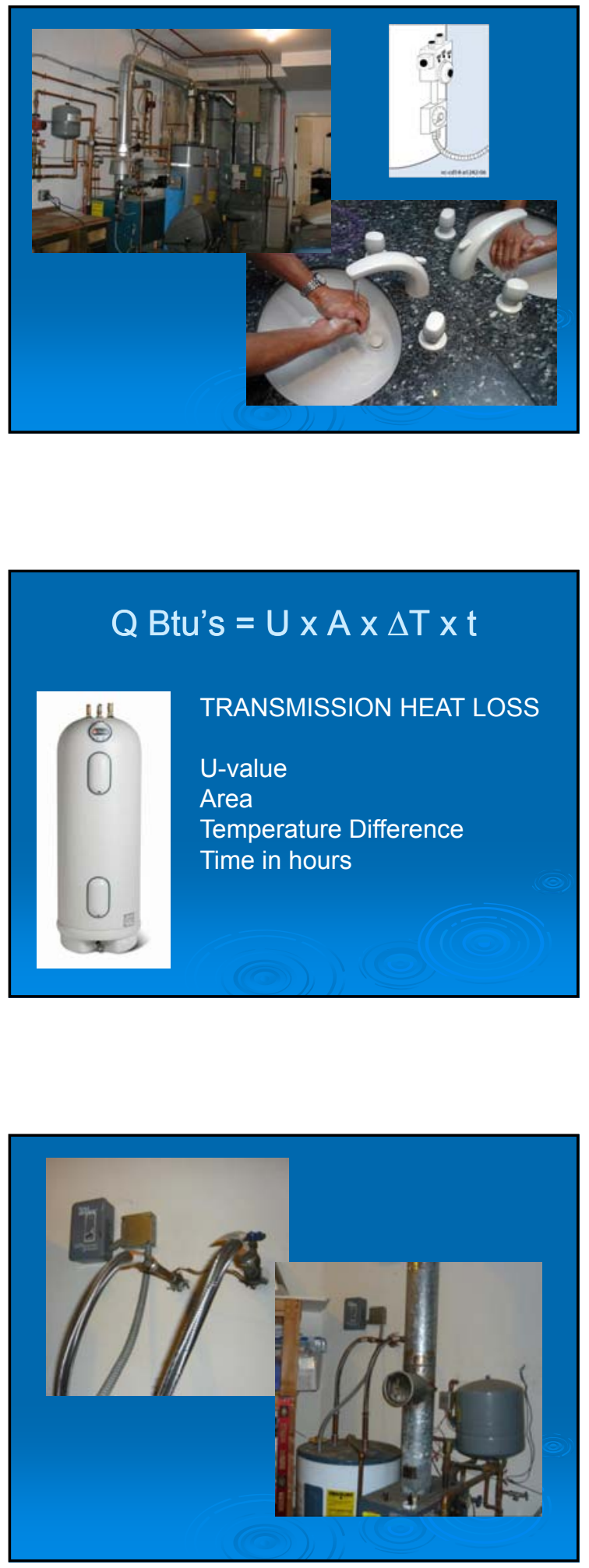


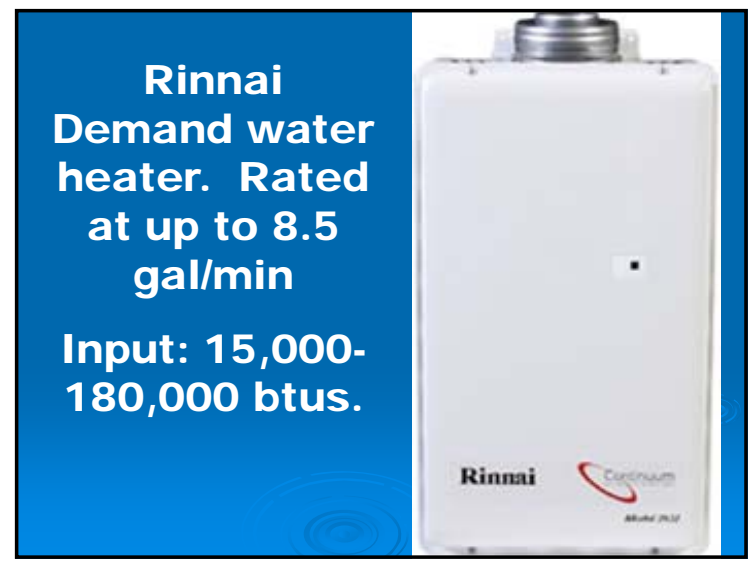

On-Demand Water
Temperature Rise

$54^{\circ} 1.5 \mathrm{GPM}$

$36^{\circ} 2.25 \mathrm{GPM}$

$27^{\circ} 3.0 \mathrm{GPM}$
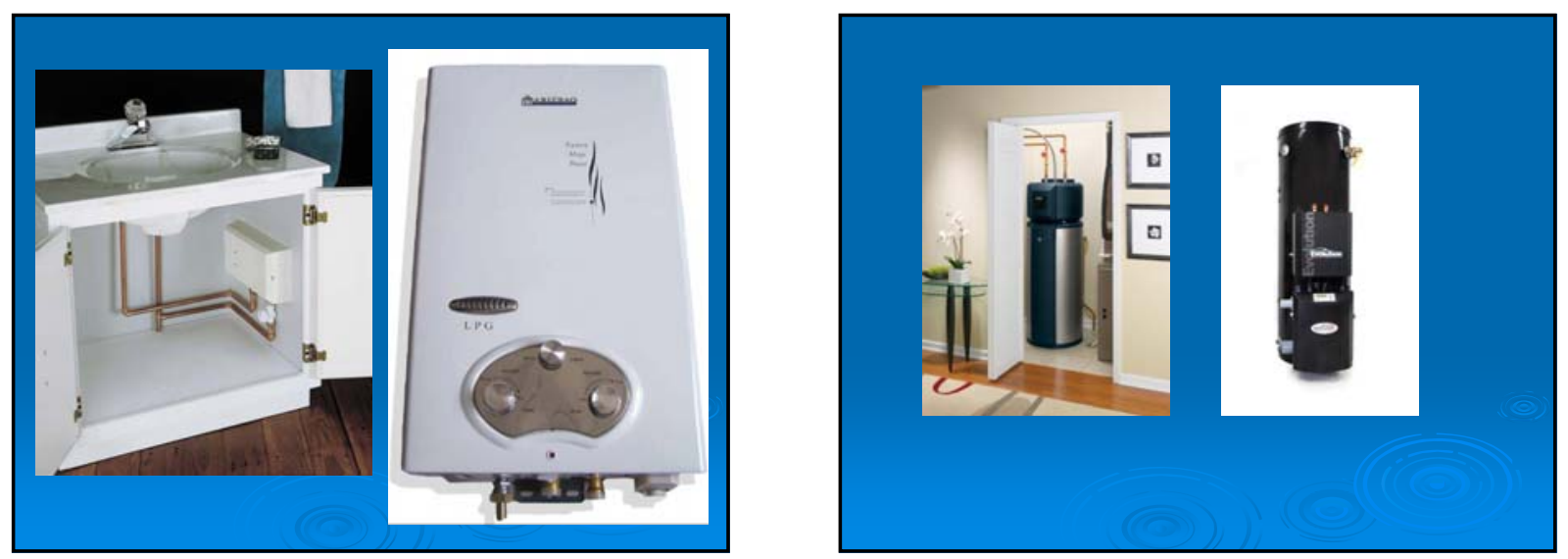

\section{Heat Pump Water Heaters?}

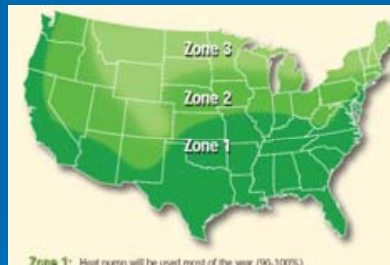

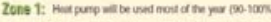

Zons 2: Cintonmon

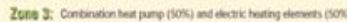

\section{A few design tips}

$>$ For multi-story buildings - add a little extra heat in the lower floor rooms, or the prevailing windward side. You can subtract a little heat from the upper rooms.

$>$ Think combination heating strategies to meet design heat load. (Direct Vent Gas Fireplace)

$>$ With an attached garage kept cooler than the house, some heat will flow from the house to the garage, requiring a larger heat load for the house and a smaller design heat load for the garage. 
What is a good safety factor for sizing a heating system

$>$ The less you know about the building regarding insulation and air tightness, the greater the safety margin needs to be.

$>$ With a good design heat load calculation, 10$20 \%$ additional heat capacity is sufficient.

$>$ What other sources of reliable heat are there to cover the safety factor?

- For Example: Gas Fireplace on a thermostat.

\section{Planning Loops and Zones}

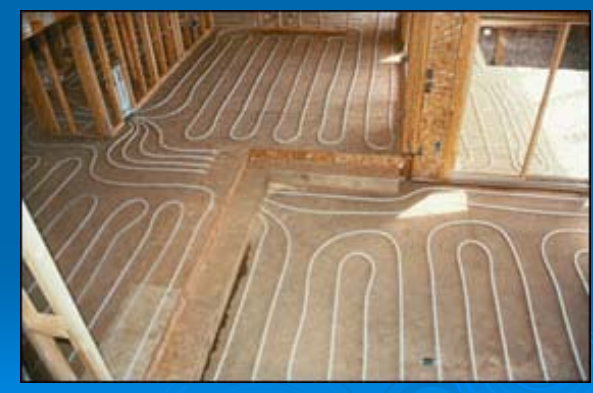

\section{Thin Slab With Sleepers}

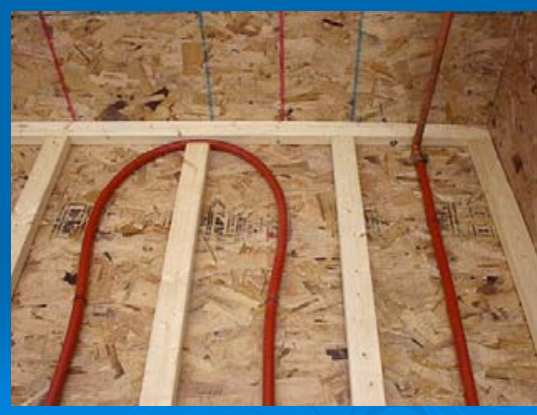

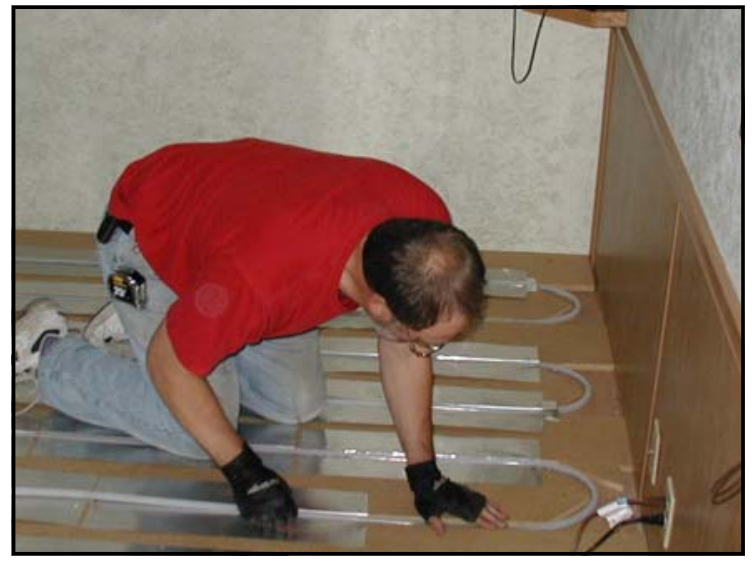
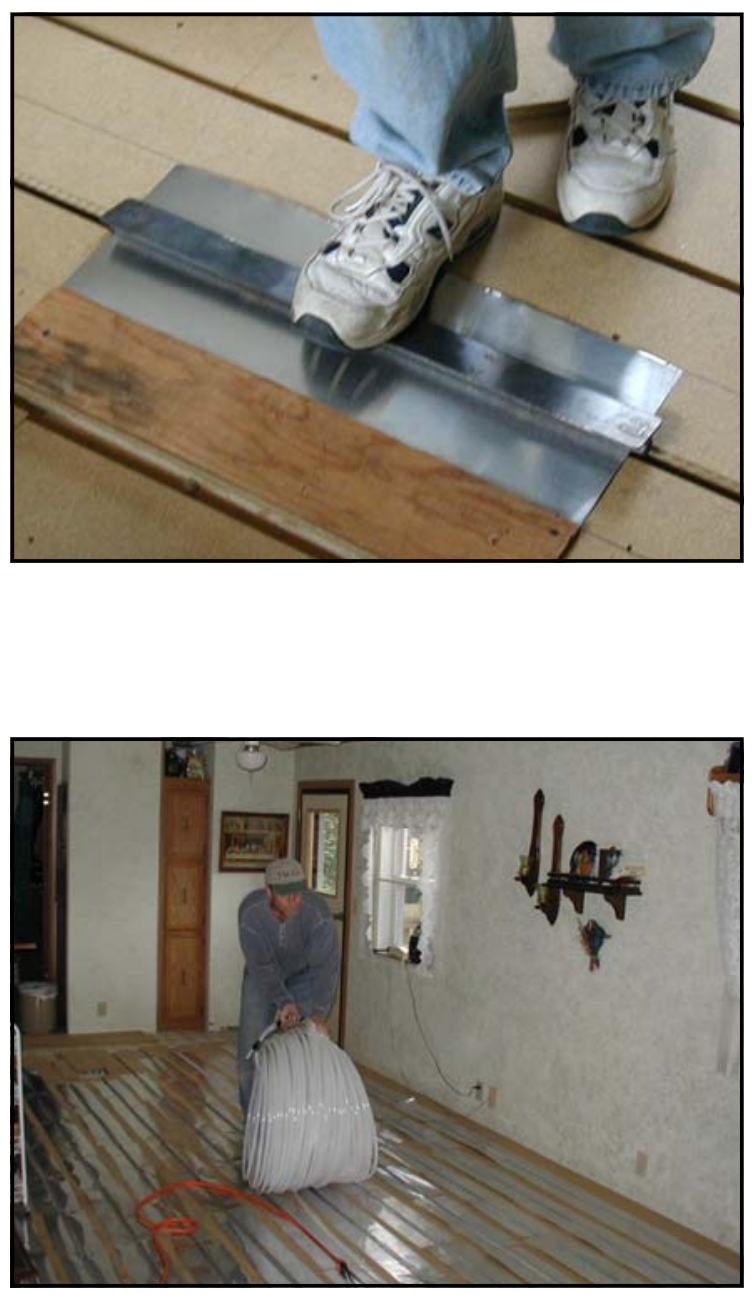

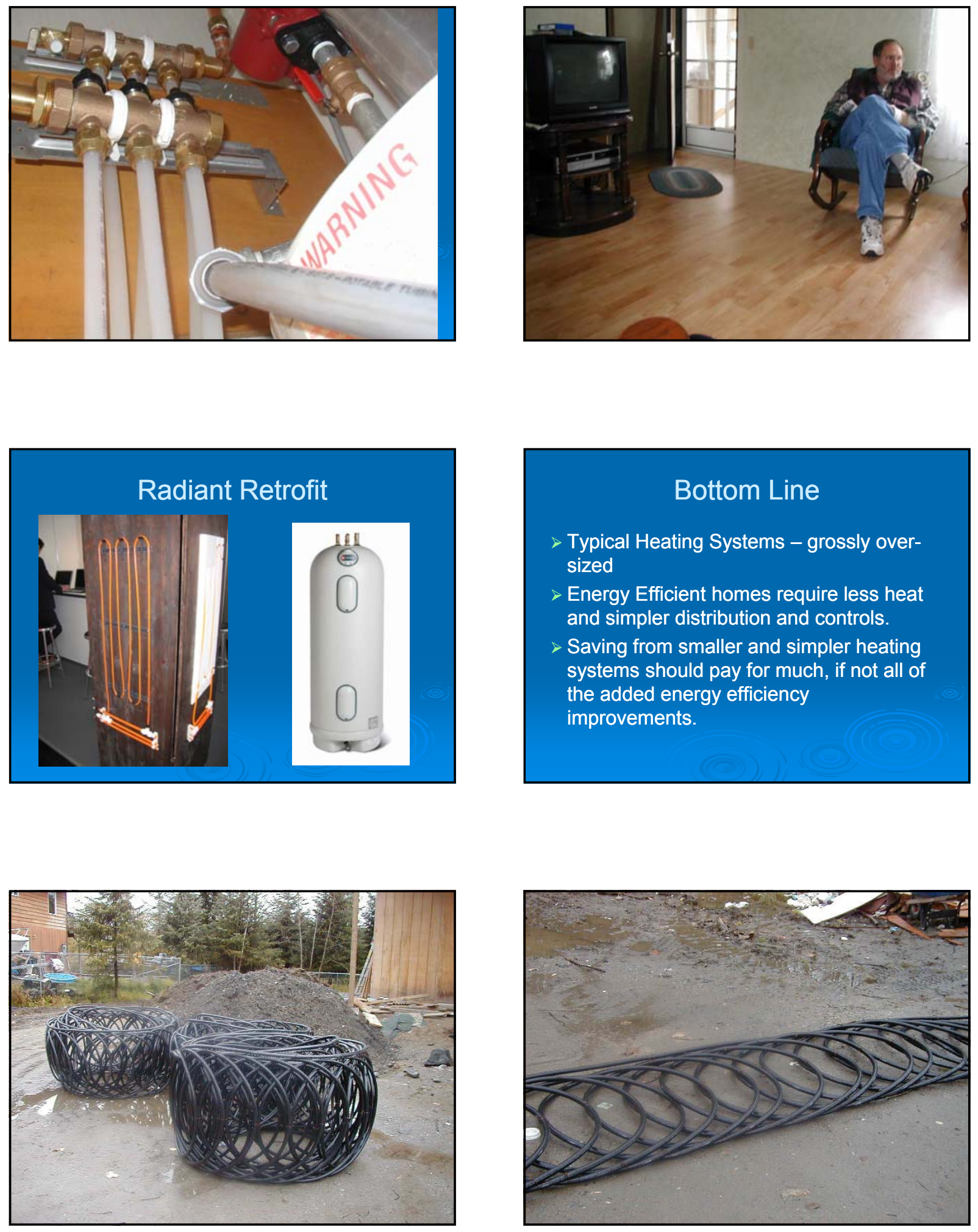

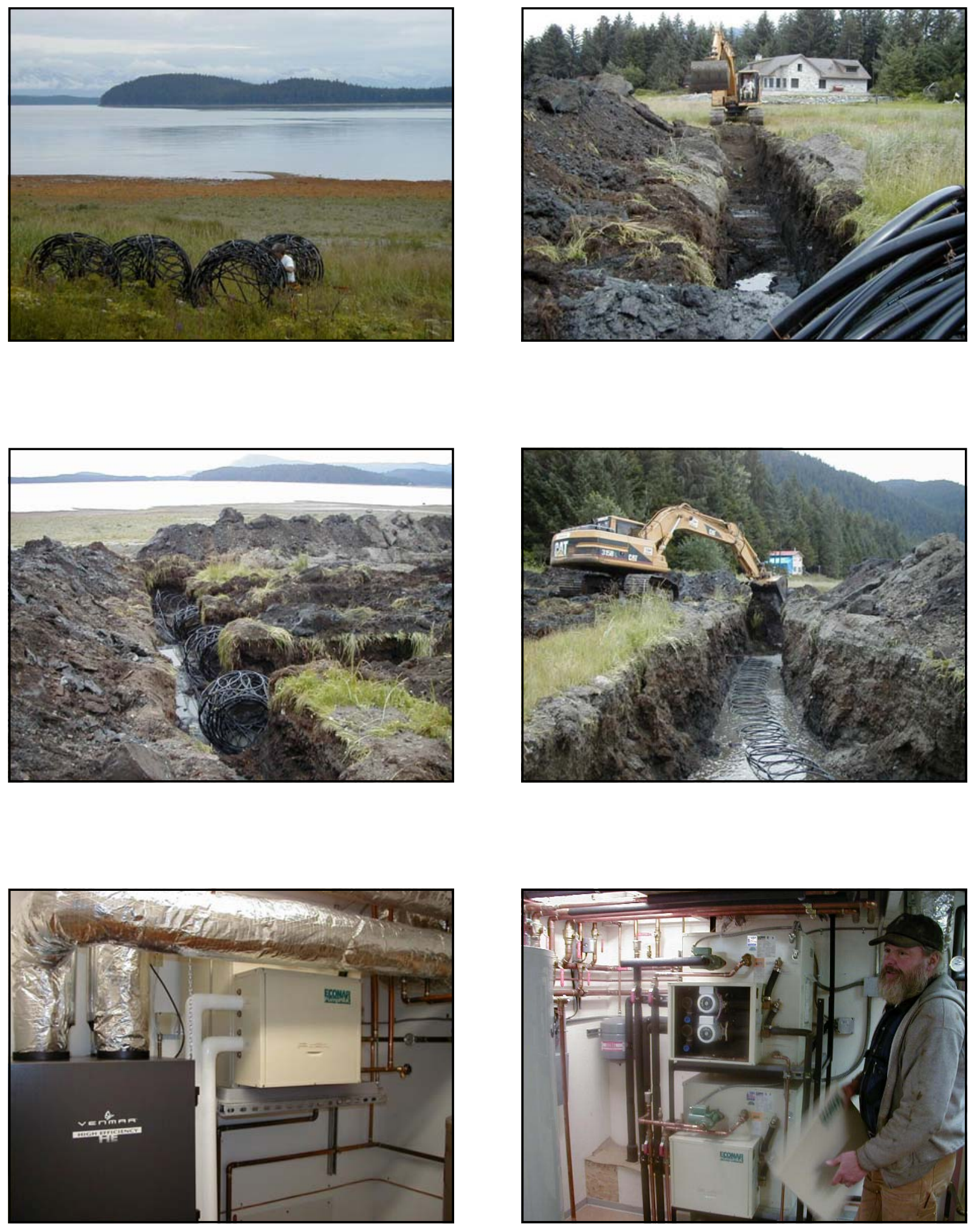

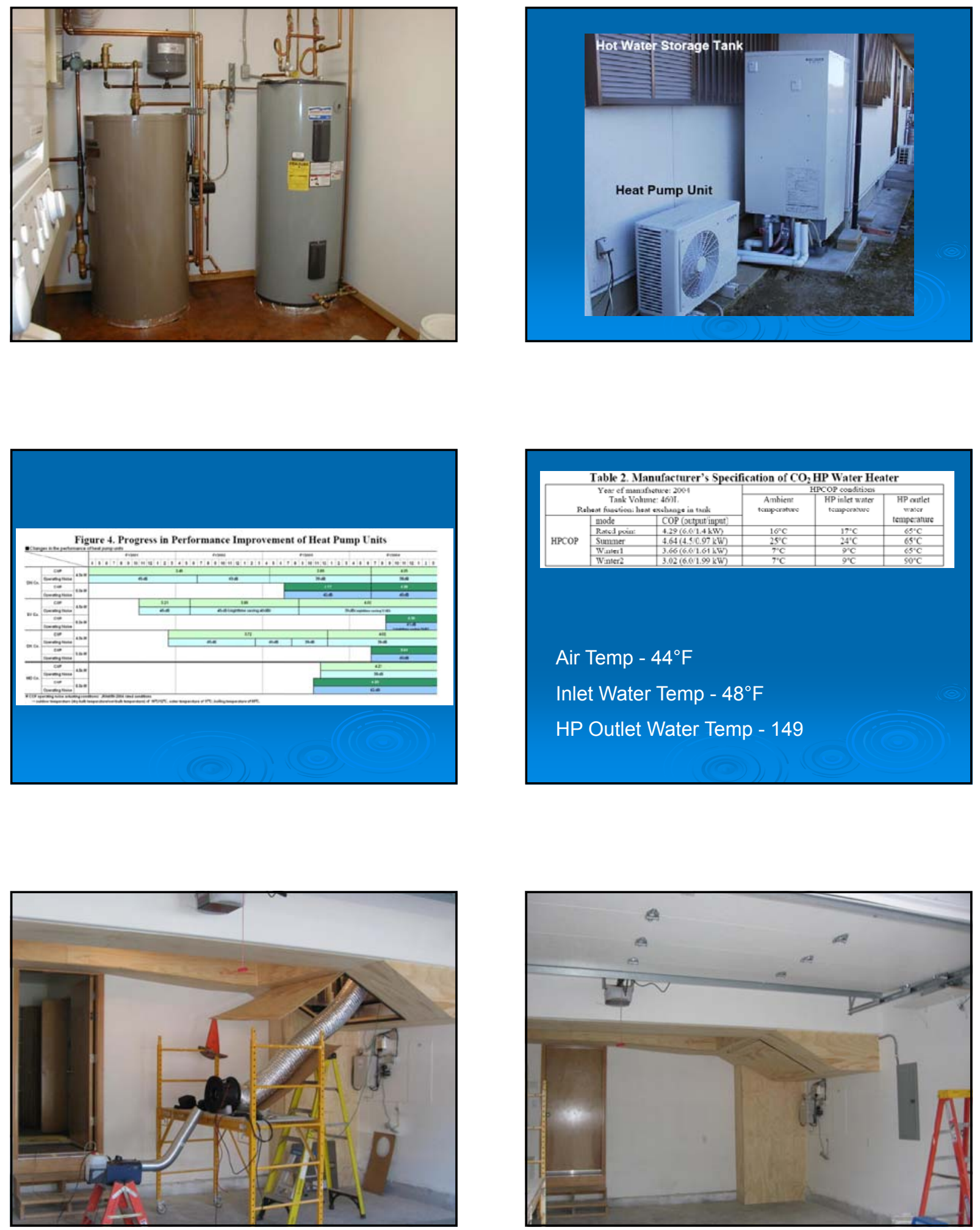

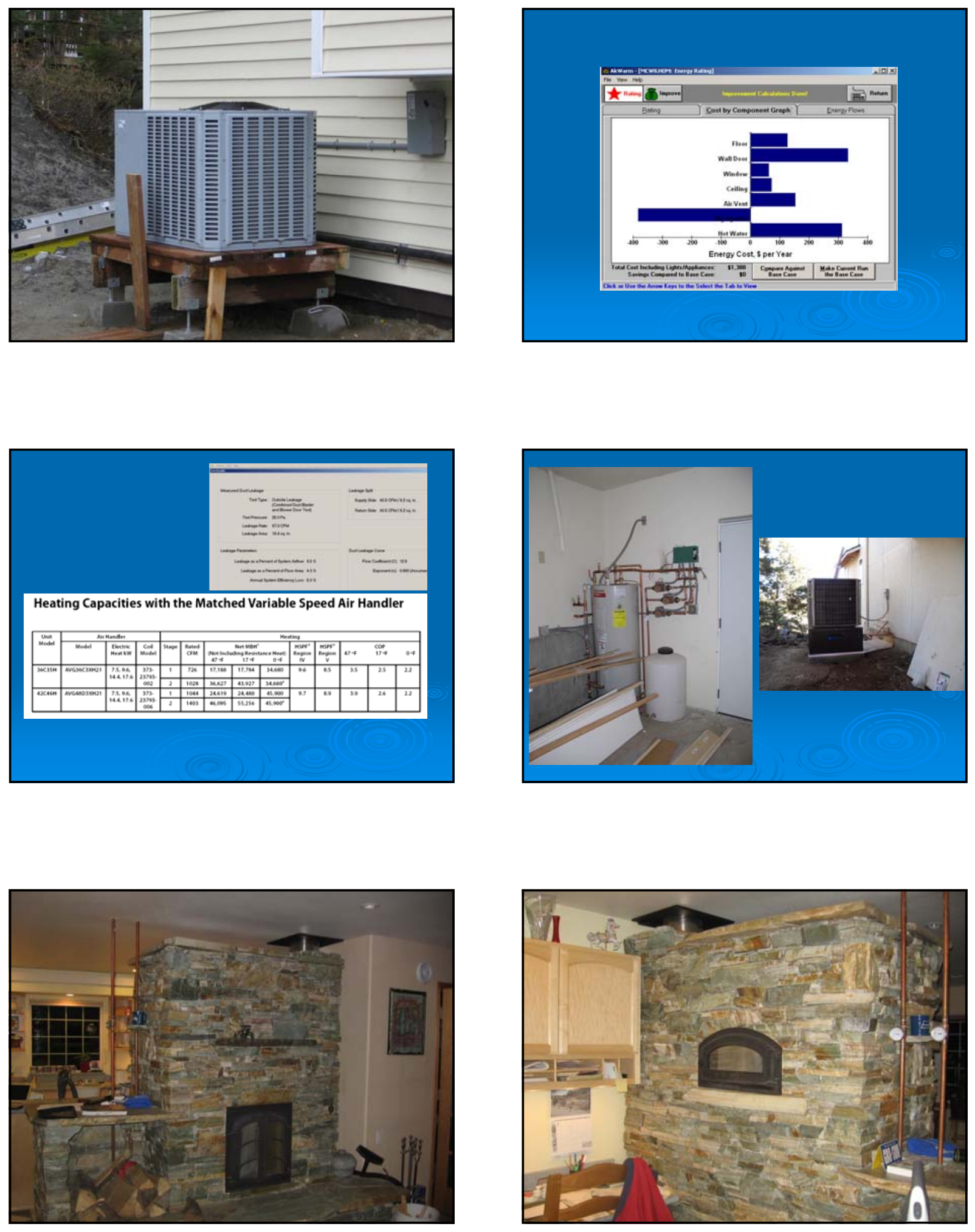

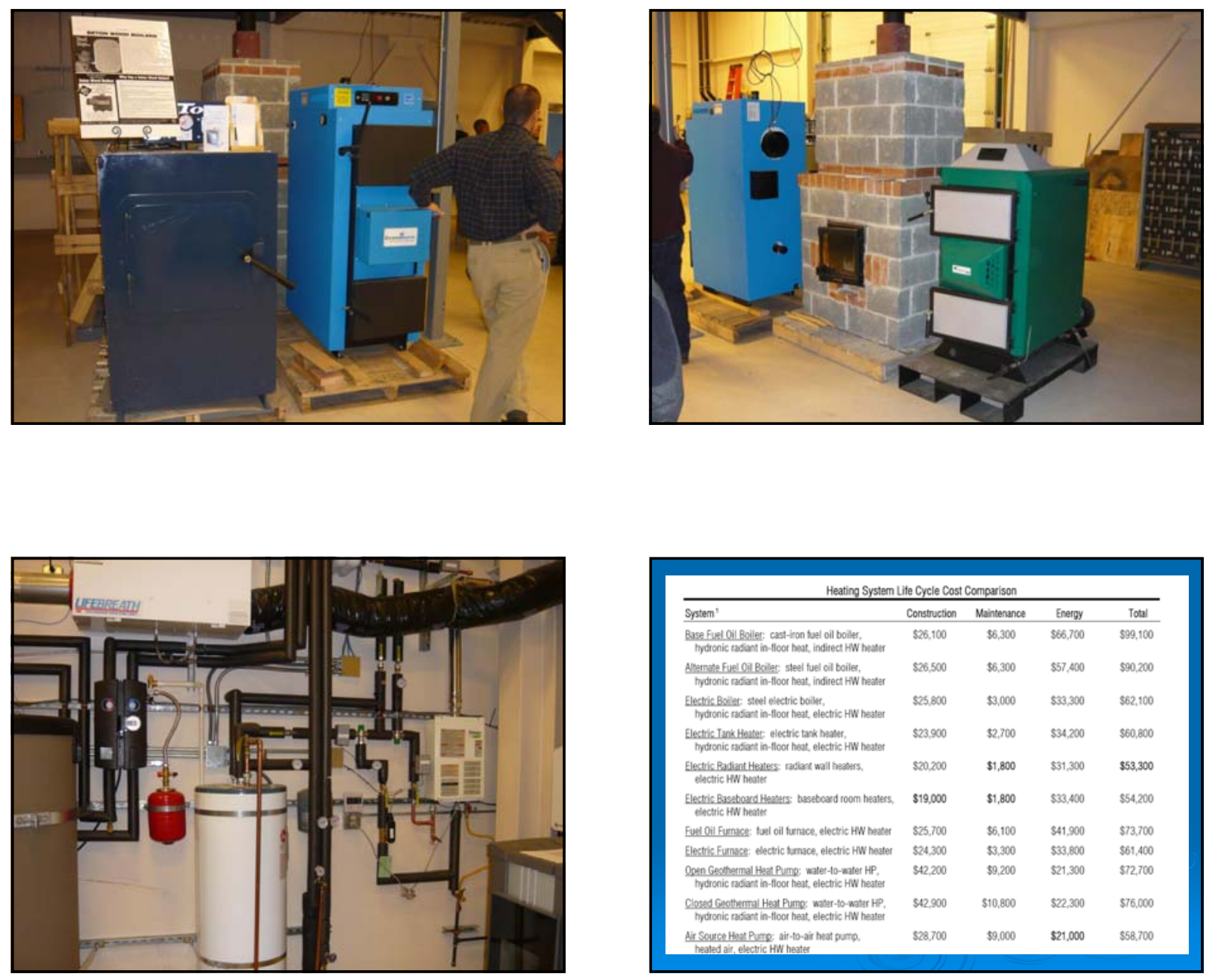

\begin{tabular}{|c|c|c|c|c|}
\hline Spstem' & Construction & Meintenance & Energy & Total \\
\hline 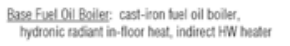 & $\$ 26,100$ & $\$ 6,300$ & $s 66,700$ & $\$ 99,100$ \\
\hline 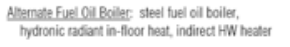 & $\$ 26,500$ & $\$ 6,300$ & $\$ 57,400$ & $\$ 90,200$ \\
\hline $\begin{array}{l}\text { Electric Brier stetel electric boiler, } \\
\text { thydronic radiant in-floor heat, electric HW heater }\end{array}$ & $\$ 25.800$ & $\$ 3,000$ & $\$ 33,300$ & $\$ 62,100$ \\
\hline $\begin{array}{l}\text { Electric Innk Heater electric tank heaser, } \\
\text { thydronic radian in-floor heat, electric HW heater }\end{array}$ & $\$ 23,900$ & $\$ 2,700$ & $\$ 34,200$ & $\$ 60,800$ \\
\hline $\begin{array}{l}\text { Electric Radinant Heates: radiant wall heaters, } \\
\text { electric HW hester }\end{array}$ & $\$ 20.200$ & $\$ 1,800$ & $\$ 31,300$ & $\$ 53,300$ \\
\hline 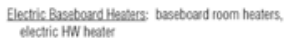 & $\$ 19,000$ & $\$ 1,800$ & $\$ 33,400$ & $\$ 54,200$ \\
\hline Fus Oil Funace: tos oil furnace, electric HW hater & $\$ 25,700$ & $\$ 6,100$ & $\$ 41,900$ & $\$ 73,700$ \\
\hline Electric funese electric Imace, electric HW heater & $\$ 24,300$ & $\$ 3,300$ & $\$ 33,800$ & $\$ 61,400$ \\
\hline 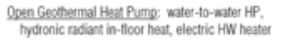 & $\$ 42,200$ & $\$ 9,200$ & $\$ 21,300$ & $\$ 72,700$ \\
\hline 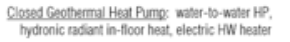 & $\$ 42,900$ & $\$ 10,800$ & $\$ 22,300$ & $\$ 76,000$ \\
\hline 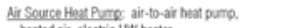 & $\$ 28.700$ & $\$ 9,000$ & $\$ 21,000$ & $\$ 58,700$ \\
\hline
\end{tabular}



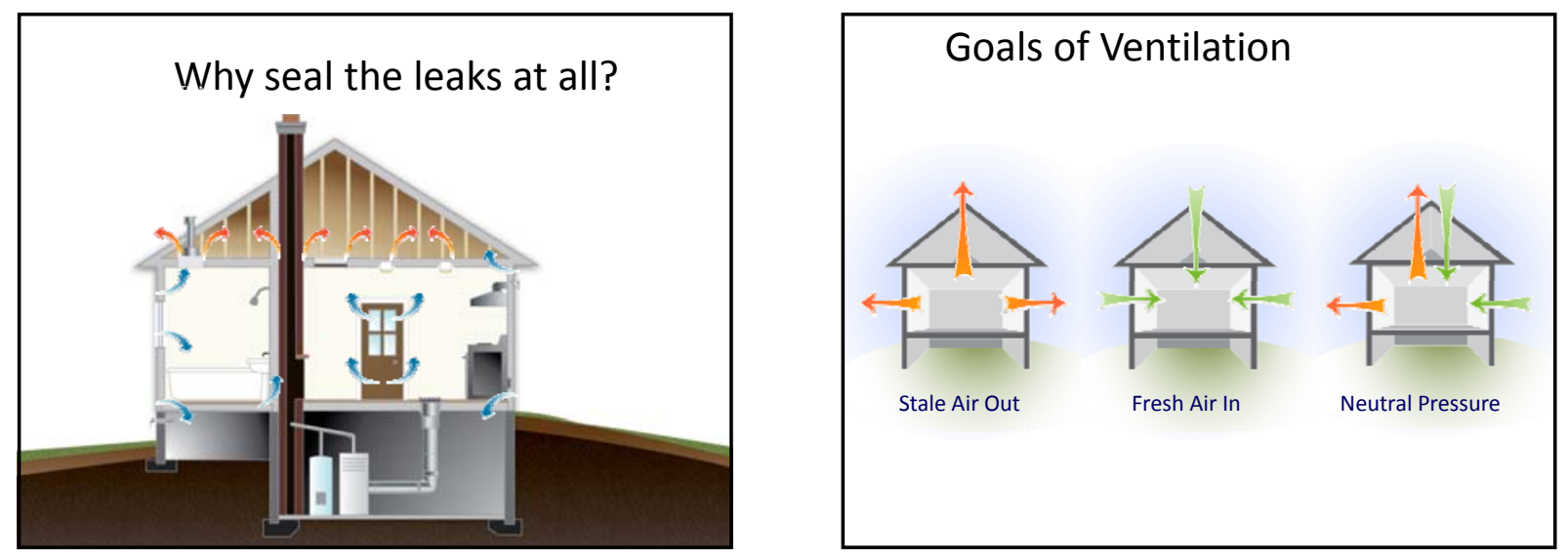

\section{Ventilation Terminology}

- Minimum Ventilation Rate (MVR)

- Building Tightness Limit (BTL)

- Cubic Feet per Minute (CFM)

- Air Changes per Hour (ACH)

- N Factor

\section{Measuring Ventilation}

Tools for Measuring IAQ and Ventilation Rates

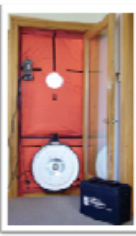

Blower Door

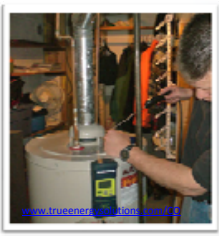

CO Testing

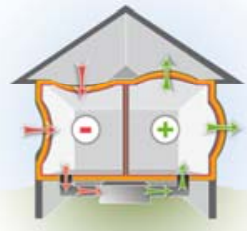

Worst Case CAZ Depressurization

\section{Ventilation Standards}

\section{ASHRAE 62.1}

- $15 \mathrm{CFM} /$ Person total

- $0.35 \mathrm{ACH}$

- Volume based on profile

\section{ASHRAE 62.2}

- $7.5 \mathrm{CFM} /$ Person mechanical

- $1 \mathrm{CFM} / 100 \mathrm{ft}^{2}$

- Volume based on footprint
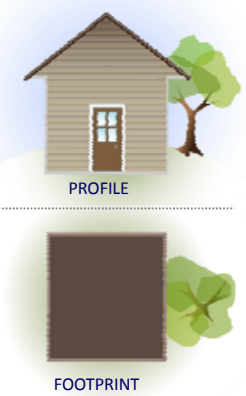

\section{Sample ASHRAE Calculations}

ASHRAE 62.1 and 62.2

- 5 People

- 3-Bedroom

- $8,000 \mathrm{ft}^{3}$ home

- Post-Weatherization Blower Door Results $=\mathbf{8 0 0}$ CFM $_{50}$

- Existing Ventilation = 20 CFM fan

- Climate Zone 2, Well-shielded 1.5 story $(\mathrm{N}=20)$ 


\section{L.BL Climate Zone Map}

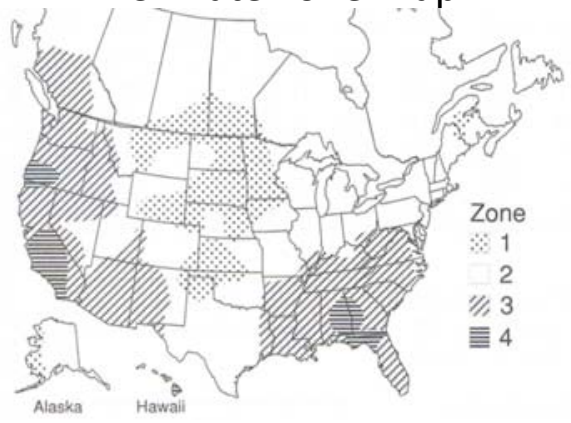

\section{$\mathrm{N}$-Factor}

\begin{tabular}{|c|c|c|c|c|c|}
\hline Climate Zone & \# of Stories > & 1 & 1.5 & 2 & 3 \\
\hline \multirow{3}{*}{1} & Well-shielded & 18.6 & 16.7 & 14.9 & 13.0 \\
\hline & Normal & 15.5 & 14.0 & 12.4 & 10.9 \\
\hline & Exposed & 14.0 & 12.6 & 11.2 & 9.8 \\
\hline \multirow{3}{*}{2} & Well-shielded & 22.2 & 20.0 & 17.8 & 15.5 \\
\hline & Normal & 18.5 & 16.7 & 14.8 & 13.0 \\
\hline & Exposed & 16.7 & 15.0 & 13.3 & 11.7 \\
\hline \multirow{3}{*}{3} & Well-shielded & 25.8 & 23.2 & 20.6 & 18.1 \\
\hline & Normal & 21.5 & 19.4 & 17.2 & 15.1 \\
\hline & Exposed & 19.4 & 17.4 & 15.5 & 13.5 \\
\hline \multirow{3}{*}{4} & Well-shielded & 29.4 & 26.5 & 23.5 & 20.6 \\
\hline & Normal & 24.5 & 22.1 & 19.6 & 17.2 \\
\hline & Exposed & 22.1 & 19.8 & 17.6 & 15.4 \\
\hline
\end{tabular}

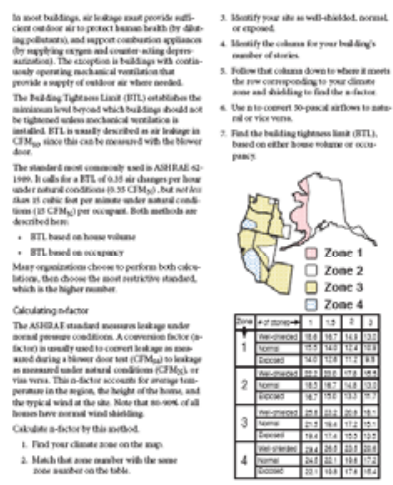

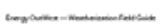

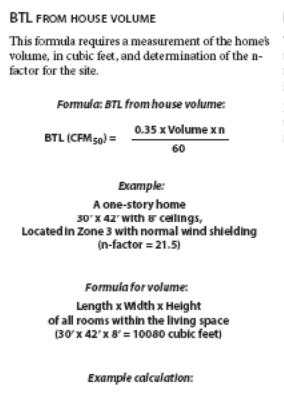

$B T L=\frac{0.35 \times 10080 \times 21.5}{60}=1264 \mathrm{CFM}_{50}$
BTL FROM OCCUPANCY

The BTL as calculated from occupancy requires

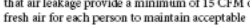

Determine the number of occupants by counting
the tedrooms, and adding one. But always assume a

inimumof five occupants

Formula: BrL from occupancy: BTL $\left(\right.$ CFM $\left.M_{50}\right)=15 \times$ (स of occupants) $\times \mathrm{x}$

Example:
A home with 4 bedroom ocated in zone 3 with nornal wind shielding (n-factor 21.5)

(nlation: $B T L=15 \times 5 \times 21.5=1612 \mathrm{CFM}_{50}$ 


\section{Static Pressure}

- Length and material of ducts

- Bends, kinks and elbows

- Grills and end-caps

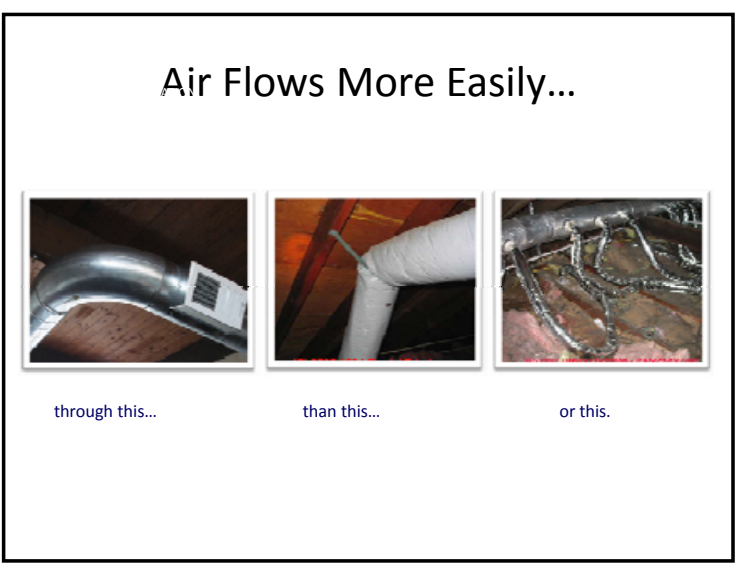

\section{Installation Guidelines - Exhaust}

Exhaust flows directly outside
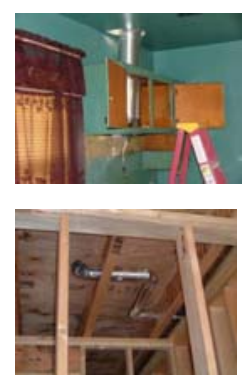

\section{Air Flows More Easily...}
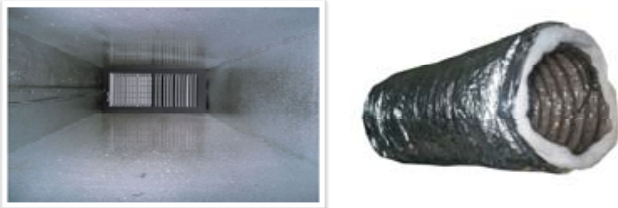

through this...

than this

\section{Installation Guidelines}

- Exhaust flows directly outside

- Short, straight, well-sealed ducts

- 2-3 feet straight pipe before elbow

- Long-radius elbows

- Smooth material

- Insulate ducts

- Keep animals out

- Follow manufacturer specs and installation instructions

Installation Guidelines - Ducts

Short, straight, well-sealed ducts

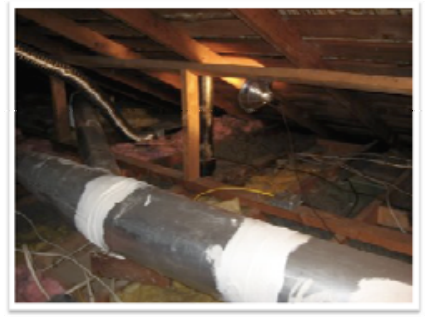


Installation Guidelines - Elbows

2-3 feet of straight pipe before the first elbow

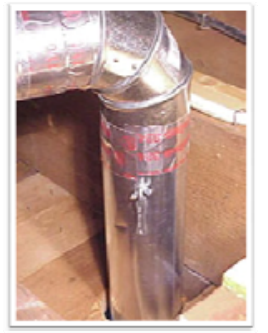

\section{Installation Guidelines - Elbows}

Long-radius elbows
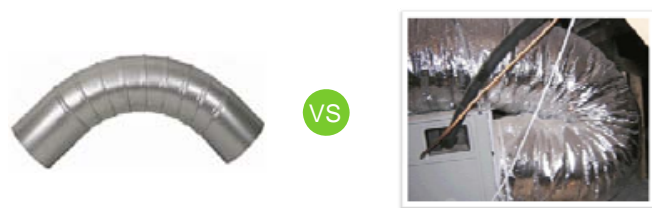

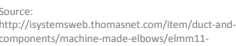

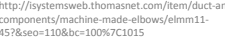

\section{Control Strategy}

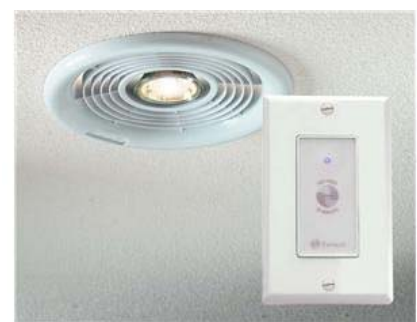

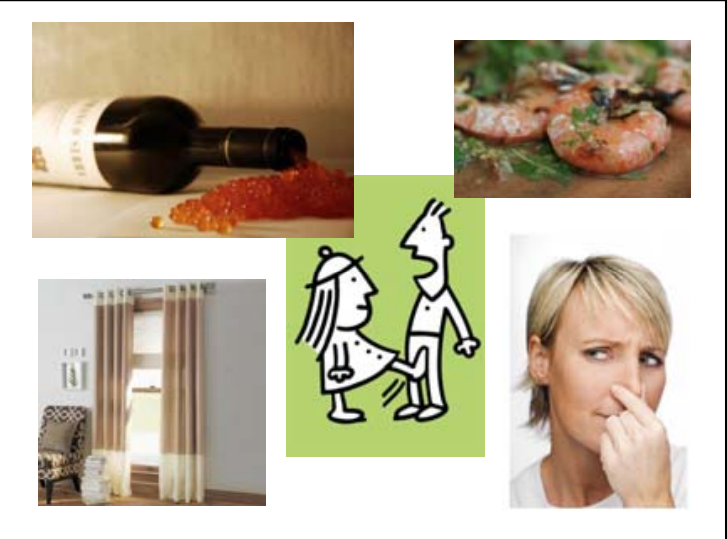

\section{Average Ventilation Rate}

Continuous venting @ 0.35 ACH, 24 hours a day

$0.35 \mathrm{ACH} \times 24 \mathrm{hrs}$

$$
24 \mathrm{hrs}=0.35 \mathrm{ACH}
$$

The other assumes a low, natural ventilation or infiltration rate of $0.22 \mathrm{ACH}$ for 23 hours a day and one hour of high, mechanical ventilation at $3.4 \mathrm{ACH}$ 


\section{Effective Ventilation Rate}

The effective ventilation rate, $\epsilon$, for these two homes/systems can be defined by considering a pollutant source like rotting shrimp in the curtain rods outgassing continuously over a long period of time.

Source strength is divided into equal parts of shrimp per hour.
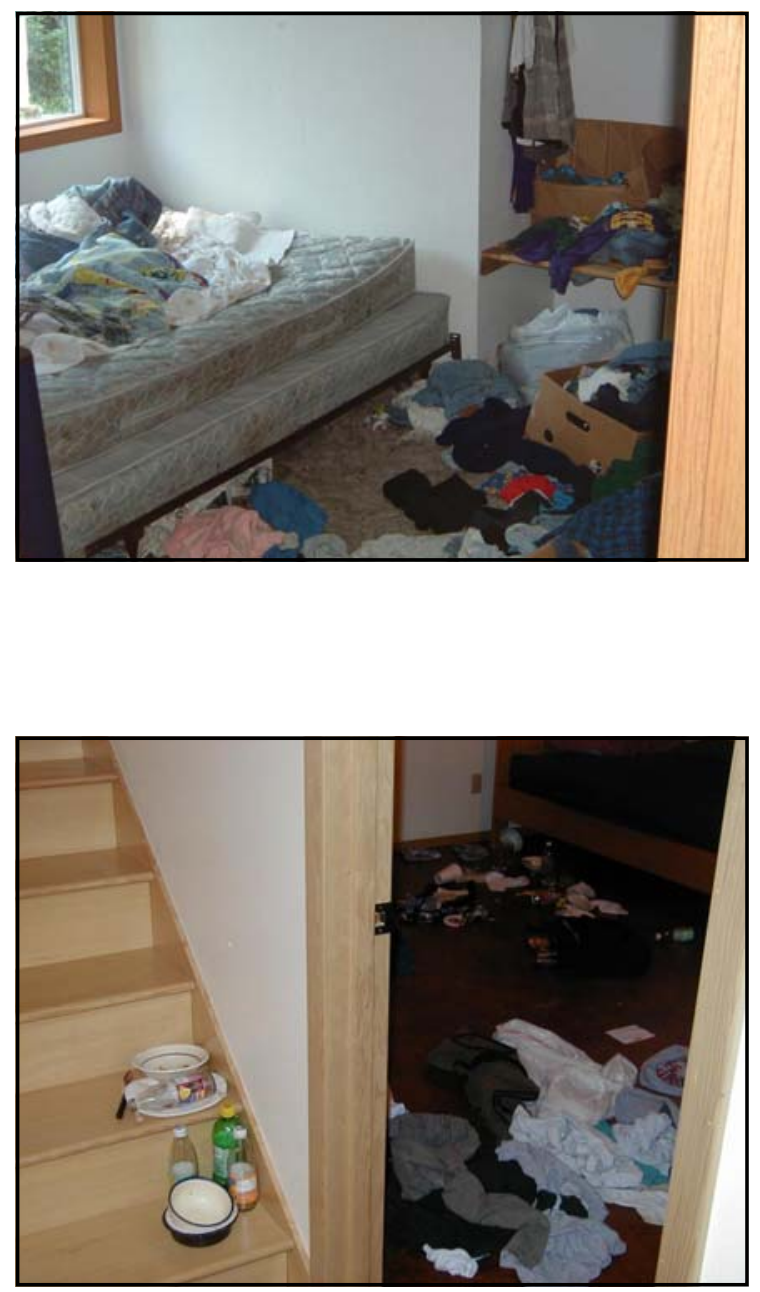

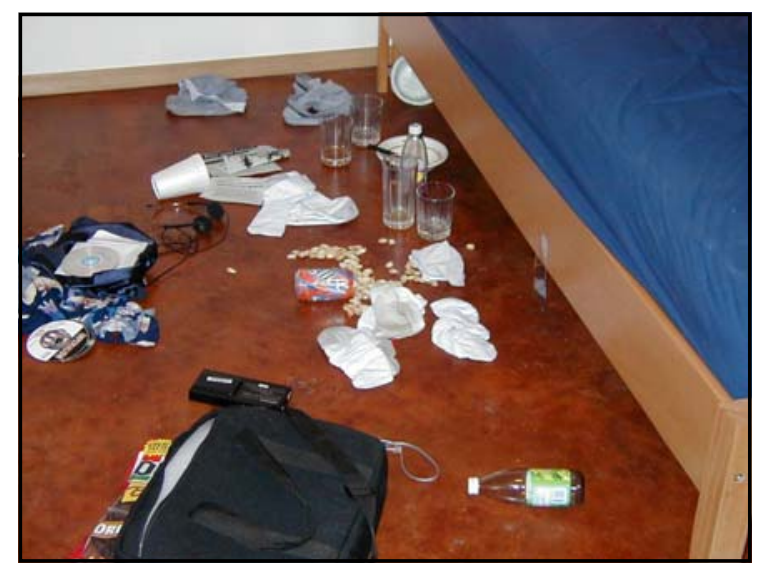

\begin{tabular}{|c|c|c|}
\hline \multicolumn{3}{|c|}{ Effective $\mathrm{ACH}$} \\
\hline & \begin{tabular}{|l|l} 
System I \\
\end{tabular} & System II \\
\hline $\begin{array}{l}\text { Pollutant } \\
\text { source } \\
\text { strength }\end{array}$ & $\begin{array}{l}1 \text { Shrimp (Shp)/hour } \\
\text { (continuous ventilation) }\end{array}$ & $\begin{array}{l}1 \text { shrimp (Shp)/hour (Ventilation @ } \\
0.22 \mathrm{ACH} \text { for } 23 \text { hours then } \\
3.4 \mathrm{ACH} \text { for one hour) }\end{array}$ \\
\hline $\begin{array}{l}\text { Average } \\
\text { concentra- } \\
\text { tion }\end{array}$ & $\frac{1 \mathrm{Shp} / \mathrm{hr}}{0.35 \mathrm{ACH}}=\frac{2.86 \mathrm{Shp}}{\text { volume }}$ & $\frac{1 \mathrm{Shp} / \mathrm{hr}}{0.22 \mathrm{ACH}} \times \frac{23}{24}+\frac{1 \mathrm{Shp} / \mathrm{hr}}{3.4 \mathrm{ACH}} \times \frac{1}{24}=\frac{4.37 \mathrm{Shp}}{\text { volume }}$ \\
\hline $\begin{array}{l}\text { Effective }(\epsilon) \\
\text { ACH }\end{array}$ & $\begin{array}{l}\frac{1 \text { Shrimp } / \mathrm{hr}}{(2.86 \mathrm{Shrimp} /}=0.35 \mathrm{ACH} \\
\text { air volume) }\end{array}$ & $\begin{array}{l}\frac{1 \text { Shrimp } / \mathrm{hr}}{(4.37 \mathrm{Shrimp} /}=0.23 \mathrm{ACH} \\
\text { air volume) }\end{array}$ \\
\hline
\end{tabular}

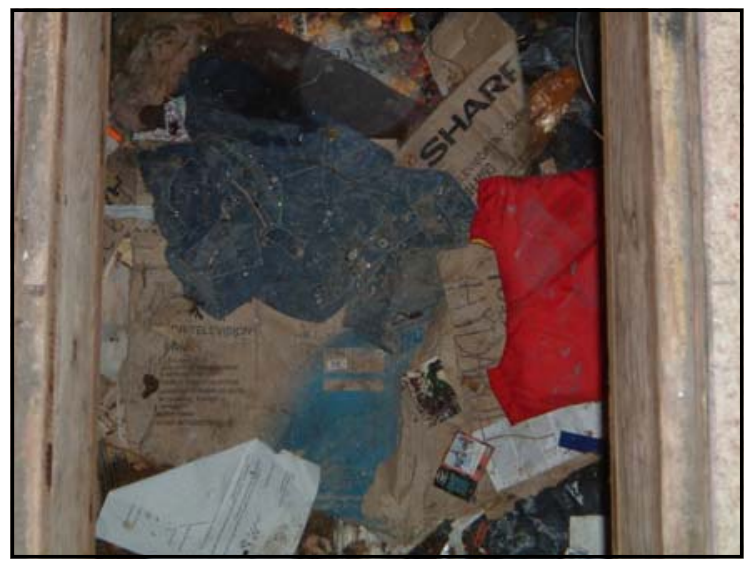




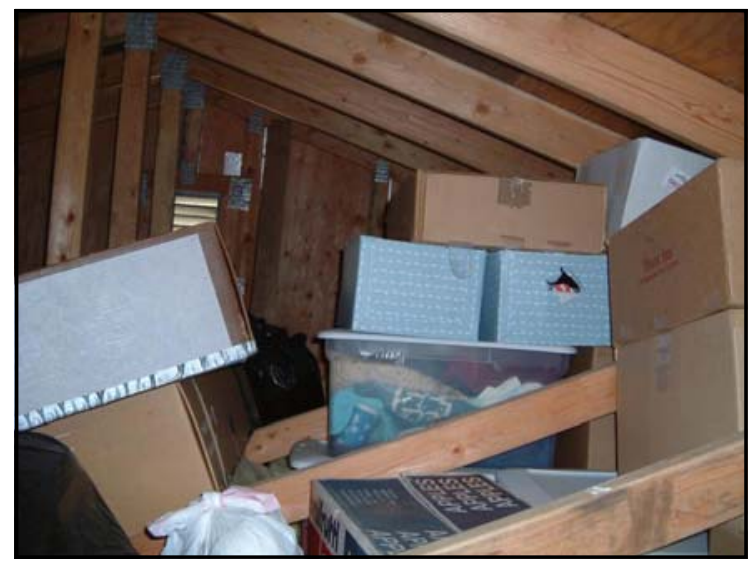




\section{Appendices 3}

Trainee Application Packet (Example) 


\section{Weatherization Training}

Qualifications for Weatherization training are participants who pass the Department of Energy Pre-Training exam and are considered as prospective job applicants for hire upon completion of training.

Please contact your local Tribal office or Marianne Jacobs for detailed information including; 1) Pre-training exam to qualify, 2) Native Weatherization Training Application 3 ) training costs and advance payment, 4) reimbursement to cover cost of training and travel expenses.

Training dates are scheduled in Juneau at the University of Alaska Southeast:

\section{October 18 - 20, 2010 Juneau, Alaska}

Additional training sessions will be scheduled during the coming year. Please feel free to submit your application and you will be notified upon availability of training.

Participants may receive training that includes the following or as mandated by the weatherization program:
A) Hands-on \& Technical Weatherization training.
B) Blower door and airtightness workshops.
C) AkWarm software weatherization training.
D) Diagnostic procedures; heat loss, moisture identification, electrical safety, locating water damage.
E) Cold Climate Advanced Homebuilder Workshop
F) Ventilation Workshop

Applicants must provide copy of the following with their completed training application:
Alaska Native Identification
Drivers License
Social Security card (required for training wages upon approval)

In advance of training, the applicant must be approved for attendance. Trainee expenses must be approved and coordinated in advance by grant administration staff or management. For more information, contact Marianne Jacobs at 9074637147. 


\section{Key Dates and Activities in Preparation for \\ October 18 - 20, 2010 Training}

September 28, 2010 Successfully pass the pre-training DOE test on or before $9 / 28 / 10$.

September 28, 2010 Deadline for applying for travel assistance (20 days prior to scheduled training).

September 28, 2010 Deadline for submitting training application.

October 5, 2010 You will be notified if we are able to offer you travel assistance (14 days prior to scheduled training).

October 8, 2010 Applicants or their tribe must provide required advance deposit of $\$ 500$ toward training expenses (10 days in advance of training).

\section{October 18 - 20, 2010 Attend Training in Juneau}

November 22, 2010 Up to $\$ 500$ reimbursement on advance deposit paid following the trainee's successful attendance and completion of weatherization training. 
Applicant's Name:

Current Employer

I passed the pre-qualification training test on

Resident of:

Describe past/current job positions or experience related to weatherization work and/or the field of construction, laborer or technician:

Explain the reason that you need weatherization training:

Current and previous employers:

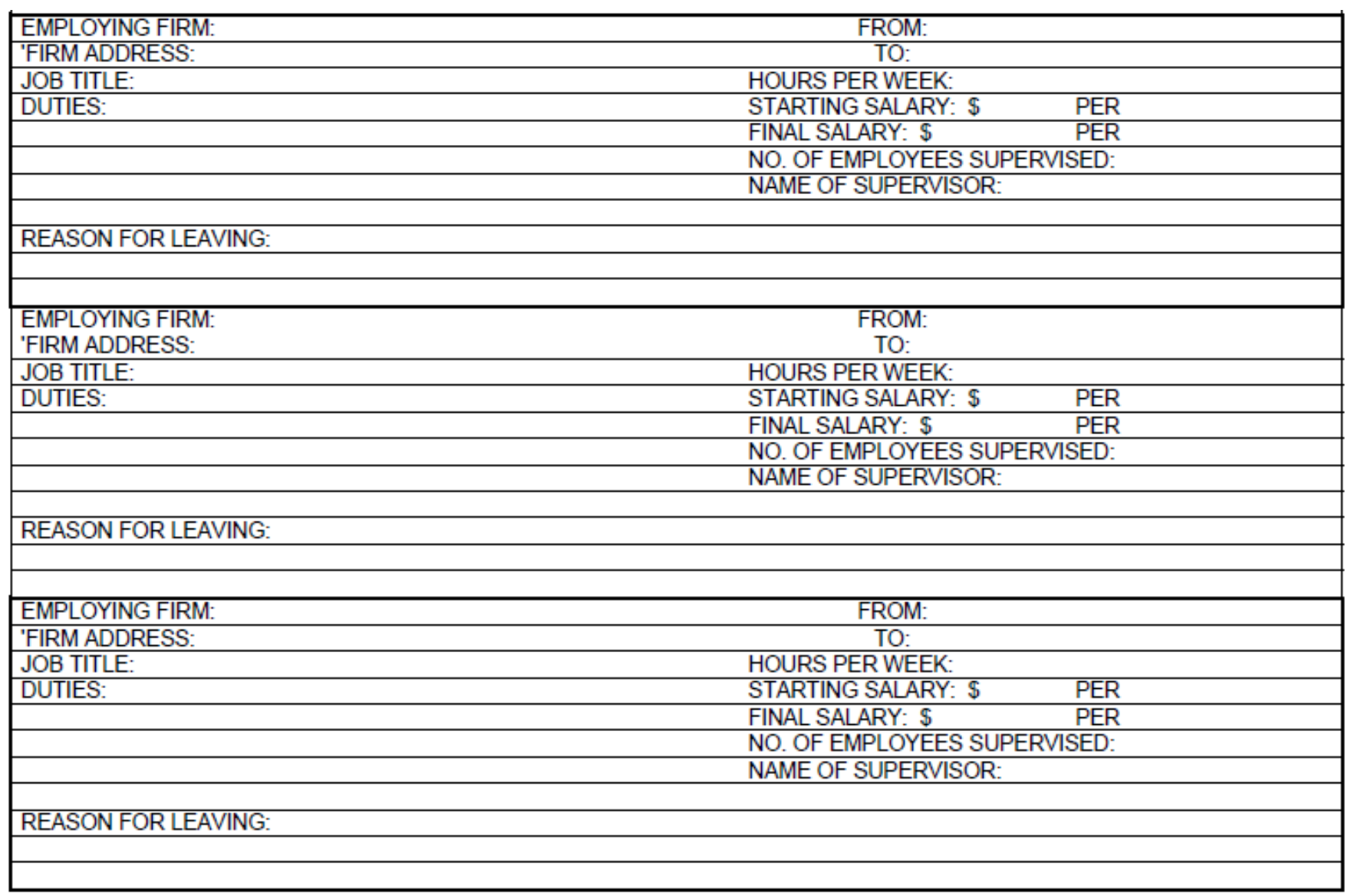




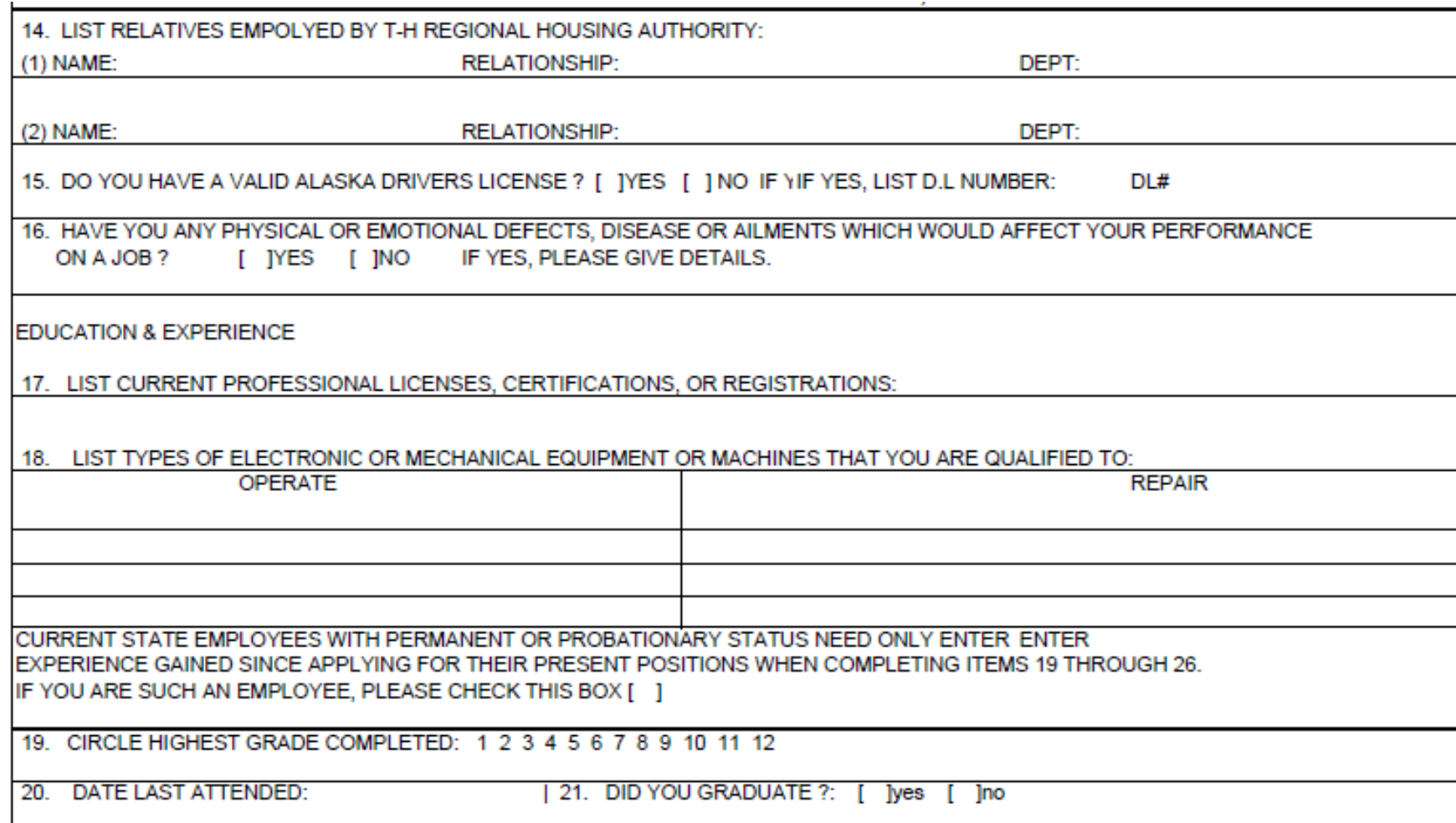

22. NAME AND ADDRESS OF GRADE OR HIGH SCHOOL LAST ATTENDED:

23. HIGH SCHOOL EQUIVALENCY CERTIFICATE (GED): (ISSUING AGENCY, NUMBER, DATE)

24. HIGH SCHOOL COURSES MOST RELATED TO THIS JOB CLASS:

25. EDUCATION OR TRAINING RECEIVED AFTER HIGH SCHOOL:

\begin{tabular}{|c|c|c|c|c|c|c|}
\hline & NO. OF & NO. OF & & & & \\
\hline COLLEGE OR VOCATIONALTRADE & QUARTER & SEMESTER & & GRAD & DEGREE & MAJOR OR SUBJECTS \\
\hline SCHOOL NAME \& LOCATION & HOURS & HOURS & & UATED & AND & \\
\hline & EARNED & EARNED & OTHER & YES/NO & YEAR & \\
\hline & & & & & & \\
\hline & & & & & & \\
\hline & & & & & & \\
\hline & & & & & & \\
\hline & & & & & & \\
\hline & & & & & & \\
\hline & & & & & & \\
\hline
\end{tabular}

\section{CERTIFICATE OF APPLICANT}

I HEREBY CERTIFY THAT ALL INFORMATION MADE ON OR IN CONNECTION WITH THIS APPLICATION IS TRUE AND COMPLETE TO THE BEST OF MY KNOWLEDGE AND BELIEF. I UNDERSTAND THAT ANY MISREPRESENTATION OR CONCEALMENT OF MATERIAL FACT WILL BE SUFFICIENT GROUND FOR REJECTION OF MY APPLICATION, REMOVAL FROM THE ELIGIBLE LIST, OR REMOVAL FROM EMPLOYMEN

DATE: SIGNATURE ( in ink )

CHECK YOUR APPLICATION! BE SURE THAT YOU HAVE FILLED IT IN COMPLETELY. 


\section{Participant Training Agreement}

1. If my Training Request is approved, I agree to report to training on time each day of training (TBD 8am-5pm) and complete all course work during the class.

2. I agree that after I have completed the training, I will continue to work for my current employer or Tlingit-Haida Regional Housing Authority for a period of time not less than nine (9) months unless I am involuntarily separated (laid off or reduction in force).

3. If I do not complete the training course as described per this Training Agreement, without good reason, I may be asked to reimburse the Tlingit-Haida Regional Housing Authority for training fees and travel expenses.

4. If I voluntarily leave my current employment or I am dismissed for cause before completing a period of time not less than three (3) months, I agree to reimburse the Tlingit-Haida Regional Housing Authority for the tuition and related fees, travel, per diem, and any other special expenses paid for in connection with my training.

5. If I am not currently employed or employed upon completion of training, I will seek employment as a result of my completion of Weatherization Training. If I cannot demonstrate my job search effort, I may be asked to reimburse the Tlingit-Haida Regional Housing Authority for training fees and travel expenses.

I have read and agree to the terms of the Participant Training Agreement above. I understand that it is expected that while on travel status I represent myself in a respectable manner and my conduct must be in accordance with the THRHA Drug-Free Workplace Policy. Drugs and alcohol are inappropriate disruptions that are not allowed while undertaking training activities delivered or paid for by THRHA or CCTHITA. Drugs and alcohol are not allowed on the premises at any time or at overnight accommodations arranged and paid for by THRHA or CCTHITA.

I understand that I will not be paid hourly wages for travel time, but may receive some allowance for meals for the day(s) of classroom training. I further acknowledge the terms and accept the conditions stipulated above. 
If your training request is approved, CCTHITA Wx Training Coordinator, Marianne Jacobs, will contact you. In the interim, please provide the following information:

Airline or Ferry schedule:

Date of departure to Juneau Time

Date of return from Juneau Time

Name of airline or Ferry:

Cost of round-trip Ferry or airline Travel:

If applicable, please have your current employer complete the following:

AUTHORIZATION:

Current Supervisor's Signature: $\quad$ Date:

Approved

Disapproved If disapproved, state reason:

Submit completed application and other requested documents to:

Email: s b e n n e t $\mathbf{n}$ t $\mathbf{h} \mathbf{r} \mathbf{h} \mathbf{a} .0 \mathrm{rg}$

Fax: (907) 7803138

The following is for administrative purpose only, to be completed by CCTHITA and THRHA:

Date completed application received by CCTHITA

Date application provided to THRHA

Applicant approved by THRHA for training on

Date application approved by THRHA and notice provided to CCTHITA

DOE Grant File Native Wx Training THRHA DE-EE0002526 
MANAGEMENT INFORMATION SYSTEM (MIS) FORM

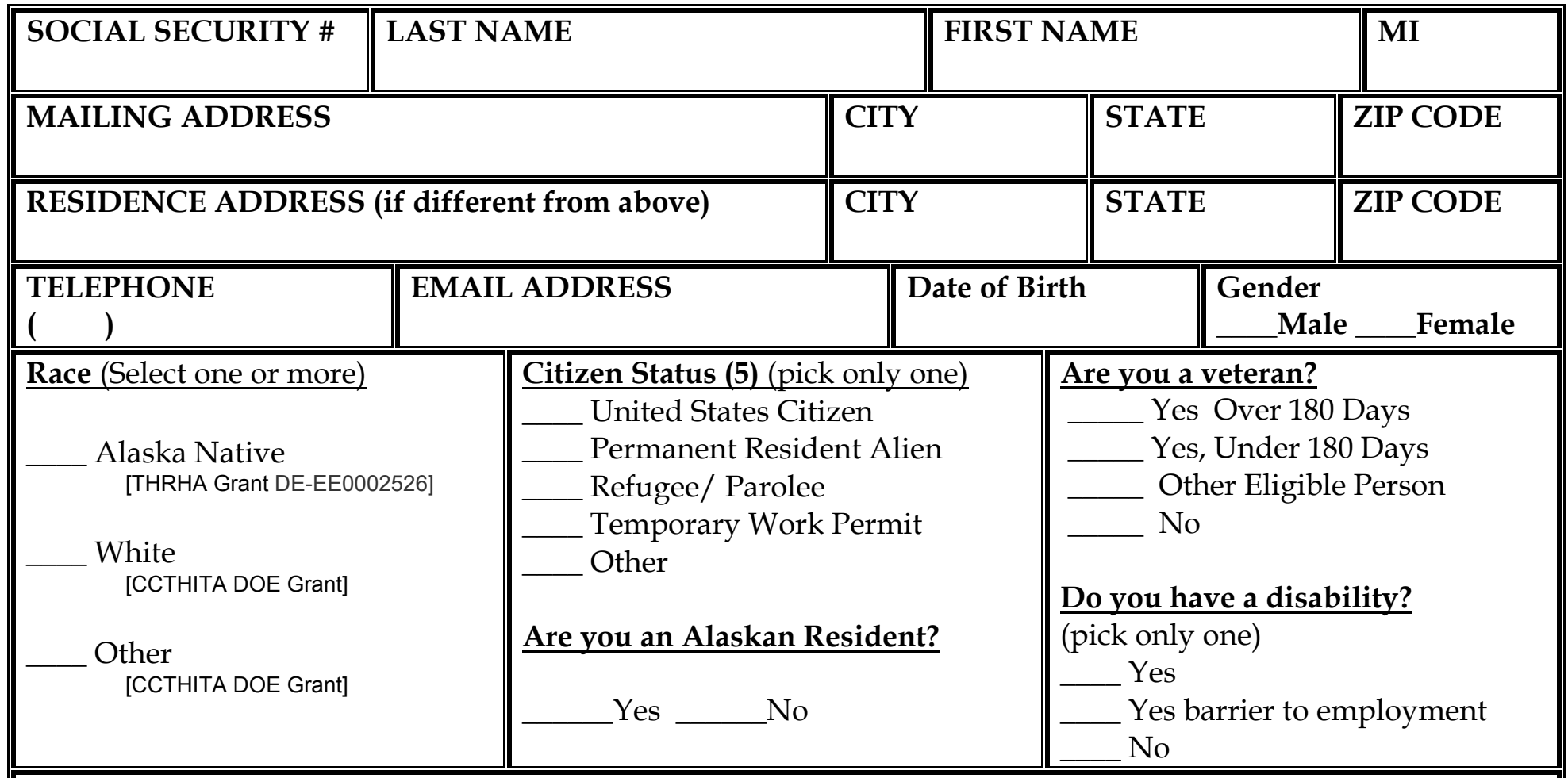

I certify to the best of my knowledge the information in this application is accurate and true. I understand that the information in this application is subject to verification and that falsification of information shall be grounds for removal from the program and may subject me to prosecution under the law. I understand that there is an applicant grievance procedure by which I can appeal decisions made with regard to this application. I have received a copy of the applicant grievance procedure.

I hereby give the Central Council of Tlingit and Haida Indian Tribes of Alaska and/or the Tlingit-Haida Regional Housing Authority, its employees, designees, agents, and all persons or departments for whom or though whom it is acting, the absolute right and unrestricted permission to take, use my name, testimonial and biographical data and/or publish, reproduce, edit, exhibit, project, display and/or copyright photographic images or pictures of me or my child(ren), whether still, single, multiple or moving, or in which I (they) maybe included in whole or in part, in color or otherwise, through any form of media (print, digital, electronic, broadcast or otherwise) for art, advertising, recruitment, marketing fund, raising, publicity, archival or any other lawful purpose.

Dated this day of 20

Signature of Participant

Parent or Legal Guardian

Parent or legal guardian signature is required if the participant is under 19 years of age. FOLLOWING IS TO BE FILLED OUT BY ADMINISTRATION:

Charge to Grant: $\quad \square$ THRHA DE-EE0002526 CCTHITA CCTHITA DOE Grant

Date Training Started Completed Instructor: Successful Completion Yes No Certification: 


\section{INSTRUCTIONS}

1. Please print all entries on the application.

2. Social Security Number: Enter your 9-digit Social Security number.

Note: This is not your driver's license or state ID card number.

3. Last Name, First Name, Middle Initial: Enter name as it appear s on the Social Security card.

4. Mailing Address: Enter the COMPLETE address where your mail is received.

5. Residence Address: If different from the mailing address, enter the COMPLETE address where you live.

6. Telephone Number: Enter a phone number where you can be contacted (include area code).

7. Email Address: Optional. If you have an internet provider and an electronic mail address please enter the complete address; e.g., JaneDoe@hotmail.com

8. Date of Birth: Enter the month, day and year you were born. For example 10/13/1961 (October 13, 1961).

9. Gender: Check either Male or Female.

10. Race: You may select more than one race, but you must select at least one.

11. Citizen Status: Choose only one.

12. Are you an Alaskan Resident? Basically, you are a resident if you plan to establish or have established permanent residence in the State of Alaska.

13. Are you a veteran? Answer Yes if: (Note: Your DD Form 214 may be requested to validate data)

- Served in the United States Armed Forces and received other than a Dishonorable Discharge.

- Called to active duty in the United States Armed Forces, have a Southwest Asia Campaign Medal, or a Armed Forces Expeditionary Medal, and received other than an Dishonorable Discharge.

- Determined an "Eligible Person" by the Department of Veteran Affairs.

14. Do you have a disability? Select one of the following answers:

- Yes - if you have a disability, but it does not prevent you from working.

- Yes barrier to Employment - if you need reasonable accommodations to accomplish the tasks for which you are being trained.

- No - if you have no disability. 


\section{Weatherization Training Juneau, Alaska October 18-22, 2010}

\section{Travel Assistance}

We are pleased to offer travel assistance for people attending Weatherization Training who live outside the Juneau area. Because limited funds are available, please review the criteria below to determine if you are eligible.

Deadline for applying for assistance is September 28, 2010 (20 days prior to scheduled training) .

If we are able to offer you assistance, you will be notified by October 5, 2010 (14 days prior to scheduled training).

Criteria for Travel Assistance

- Tribal members or Alaska Native residents are eligible.

- Applicants are required to provide a deposit of \$500 in advance of training for reimbursement following successful attendance and completion of training.

- Applicants may invite their tribe to provide the $\$ 500$ deposit on their behalf by October 8, 2010. (10 days in advance of training).

- A limit of two (2) travel funding reimbursements will be made for an individual on an annual basis.

Assistance will include transportation to/from Juneau, overnight accommodations, and per diem (meals) while attending weatherization training.

The amount you will receive for airfare or ferry depends on your location. These amounts are determined by the cost normally associated with a given community and travel arrangements made by or approved in writing by THRHA at least 7 days in advance of travel.

The $\$ 500$ training deposit will be received and held in reserve by THRHA. Checks made payable to Tlingit-Haida Regional Housing Authority. Send to: Attn: Steve Bennett, PO Box 32237, Juneau, AK, 99803-2237. Reimbursement will be made following the successful attendance and completion of weatherization training.

If you have questions, please review the reimbursement Fact Sheet or call Marianne Jacobs at 9074637147. 


\section{NATIVE WEATHERIZATION TRAINING}

\section{Cost of Training Reimbursement Program}

\section{FACT SHEET}

Purpose. Reimbursement is available to help offset some of the costs associated with attendance of weatherization training.

Advance Payment. At least ten (10) days in advance of training, the applicant must pay \$500 as deposit for training costs. Upon successful completion of training, up to \$500 according to "allowable” expenses incurred will be reimbursed.

Reimbursement. Applicants may invite their tribe to provide the $\$ 500$ deposit on their behalf (10 days in advance of training). The $\$ 500$ deposit will be received and held by THRHA via check and payable to the same as Advance Payment made. Checks made payable to Tlingit-Haida Regional Housing Authority. Send to: Attn: Steve Bennett, PO Box 32237, Juneau, AK, 99803-2237. Reimbursement will be made following the successful attendance and completion of weatherization training. In the event that the Tribe submits advance payment on behalf of applicant / trainee, then Reimbursement is due payable to the Tribe --NOT the individual applicant / trainee.

Programs Covered. Reimbursement is available for THRHA Weatherization Training Courses.

Eligibility. You must be 1) Alaska Native, 2) successfully complete the Department of Energy pre-test exam, and 3) attend and successfully complete the training course in order to receive reimbursement for Weatherization Training sponsored by THRHA and CCTHITA.

Limits on Reimbursement. Tribal members are limited to a maximum of two (2) training reimbursements per calendar year.

What Expenses are Covered by Reimbursement? Allowable expenses are limited to TRAVEL Alaska Marine Highway ferry transportation, lodging, and per diem (meals). All expenses must be allowable under the program guidelines and verified by ORIGINAL receipts or arranged by THRHA. CCTHITA and THRHA reserve the right to determine if a cost is allowable according to the DOE grant guidelines.

How to Apply. Individuals interested in participating in the Reimbursement Program shall complete the “Native Weatherization Training Application" form. This form is available in hard copy from CCTHITA (upon request) or on-line at www.thrha.org. To be considered for reimbursement, your application must be received by CCTHITA no later than twenty (20) days prior to the start date of the course, workshop, or event, unless otherwise stated on our website or in published marketing materials. Each class, workshop, or event has a limited amount of funding available for reimbursement, so if you are interested, you are encouraged to apply early.

Cancellations. In the event the applicant's attendance is approved, and the applicant later decides not to attend the course/class/workshop/event (for whatever reason), then it is his/her responsibility to notify THRHA in writing (or the training/event sDonsor. if other than THRHA) immediatelv of their intent to 
owed due to the individual's decision to cancel his/her participation in a course/event. The approved applicant is responsible for repayment of all expenses incurred by THRHA and/or CCHITA.

Travel/Lodging. THRHA must approve in advance any and all expenses considered for reimbursement in writing or THRHA will make all necessary travel/lodging arrangements on behalf of the trainee.

Advance Class/Workshop/Training Application. In addition to applying for Reimbursement, individuals are responsible for completing all training applications, forms and submitting required documents as required for attendance of Weatherization Training.

Reimbursement Monetary Limits. Reimbursement will cover the cost of transportation, per diem, and shared overnight accommodations (minimum 2 per guest room) during the length of stay required for training.

Attendance. Trainees are required to attend all course/class/workshop/event sessions, as evidenced by the daily on-site sign-in sheets. This is a mandatory requirement and is necessary to ensure prompt reimbursement for expenses. Failure to sign-in each day can jeopardize "full" reimbursement of eligible expenses.

Complete Training Application. Trainees are required to complete, sign, and submit a "Native Weatherization Training Application” to CCTHITA to be eligible to receive reimbursement for expenses associated with a Reimbursement. The Training Application must be submitted at least twenty (20) calendar days prior to the scheduled course/class/workshop/event. Failure to submit an application and all required supporting documentation can result in non-reimbursement of expenses.

Supporting Receipts. Original receipts are required for all expenses being claimed for reimbursement. If for some reason an original is not available, please provide a written explanation as to why they are not available and forward that to THRHA.

Revisions to Program Guidelines. CCTHITA and THRHA reserves the right to modify its Reimbursement Program guidelines as necessary due to the availability of funds and other applicable requirements.

Feedback. Trainees are asked to briefly describe how the training course benefited them and/or their tribe and any positive impact that it has had on the way they and/or their tribe now does business. Specific examples of how the knowledge/practices/techniques learned at the training/event have been adopted/implemented by them and/or their employer or tribe are encouraged.

For more information contact:

Steve Bennett

Tlingit-Haida Regional Housing Authority

Tel 9077803154

Fax 9077803138 sbennett@thrha.org 


\section{Appendices 4}

Outreach (Example) 


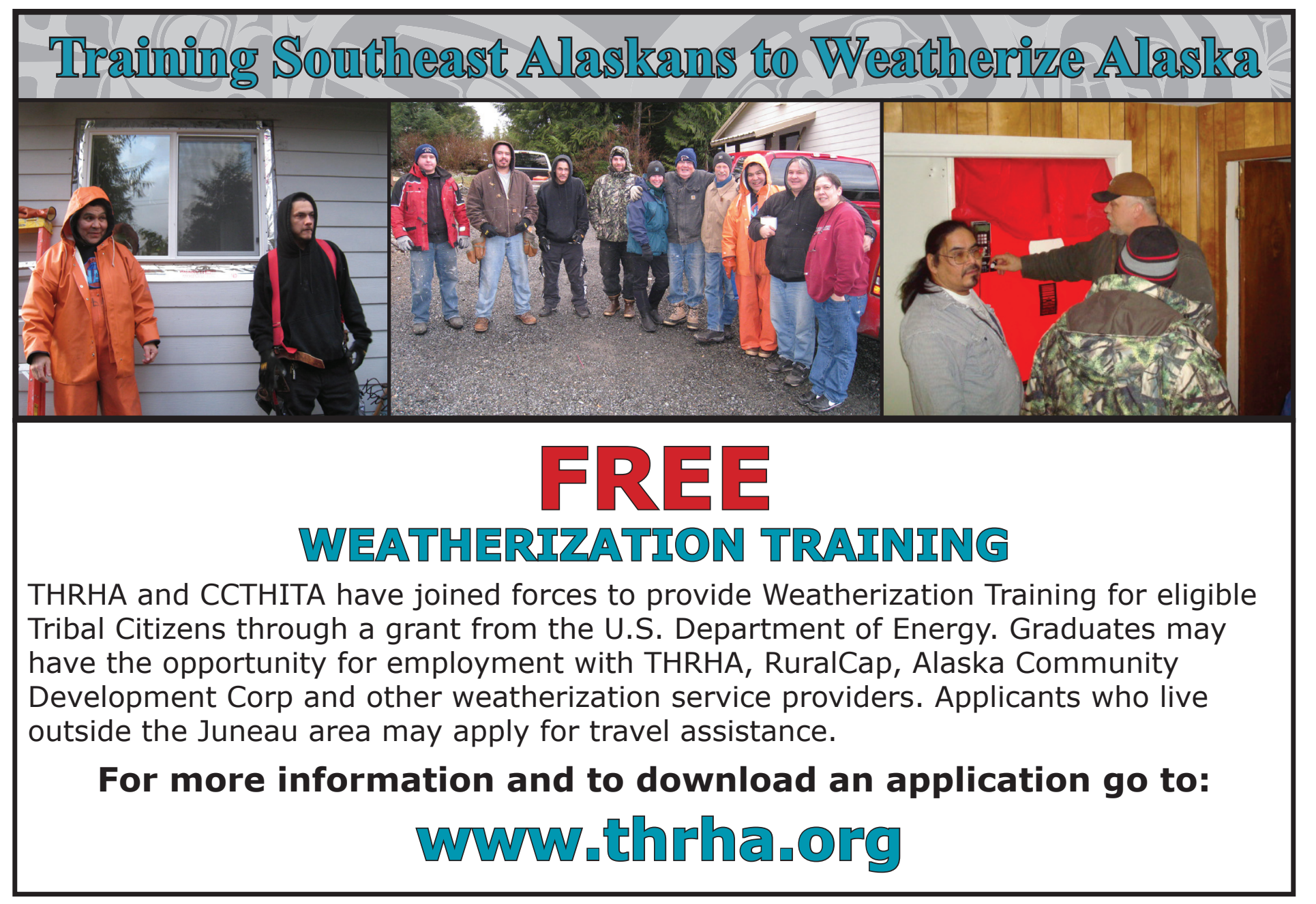

\section{ADVANCED \\ Weatherization Training}

\section{September 20 - 24}

This five day training is targeted toward individuals who are currently working in the field of weatherization. Participants will advance their knowledge of diagnostic equipment to evaluate and improve energy efficiency. The course will utilize both lecture and "hands on" activities.

For more information including travel assistance, contact:

Tlingit-Haida Regional Housing Authority Steve Bennett 907 780-6868 sbennett@thrha.org

\section{BASIC \\ Weatherization Training \\ October 18 - 22}

This five day course is designed to introduce individuals to weatherization job readiness and material installation techniques by the use of both classroom instruction and "hands-on" laboratory experience. This course is primarily designed for individuals new in the weatherization field.

For more information including travel assistance, contact:

Central Council of the Tlingit \& Haida Indian Tribes of Alaska Marianne Jacobs 907 463-7147 mjacobs@ccthita.org 


\section{THRHA Energy Cents Program}

"Putting value on energy conservation and efficiency... it makes cents"

Sharing Energy Conservation Education with Southeast Communities

THRHA is pleased to present Energy Cents! A program specifically designed for southeast families. This fall, our Energy Cents team will visit your community to share ways to save energy. Residents will have the opportunity to have a locally trained energy assessor visit your home to find ways to reduce energy costs. The high cost of energy consumption in rural communities affects everyone and THRHA is committed to sharing ways to reduce energy costs!

\section{Things to Save Energy}

Switch to efficient lighting. Changing just

1 six of your most used incandescent bulbs to CFLs will save $\$ 100$ per year.

Manage your thermostats. For every degree

2 you lower your thermostat you save about two percent $(2 \%)$ off your heating bill.

Turn off and unplug. Use Smart Power

3 Strips to save energy. Many electronics go into standby mode when you turn them off.

Get an Energy Audit. For every $\$ 1$ decrease

4 in annual energy costs, the market value of a home increases by $\$ 20$.

Reduce hot water heater temperature.

Reducing your water setting to $120^{\circ} \mathrm{F}$ increases maximum efficiency.

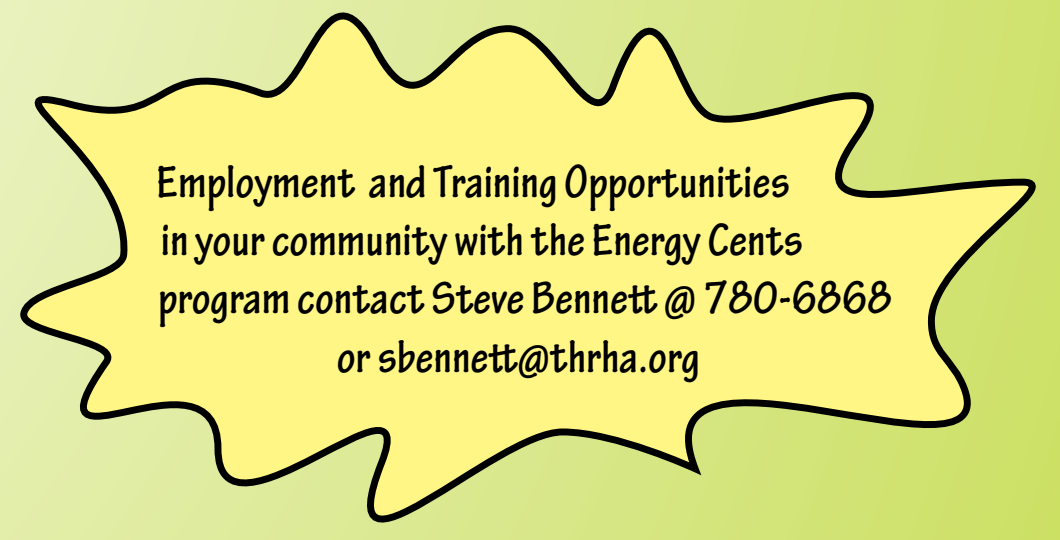

Training Opportunities: September 17- 21, 2012 Alaska Building Science Center 5446 Jenkins Drive, Juneau

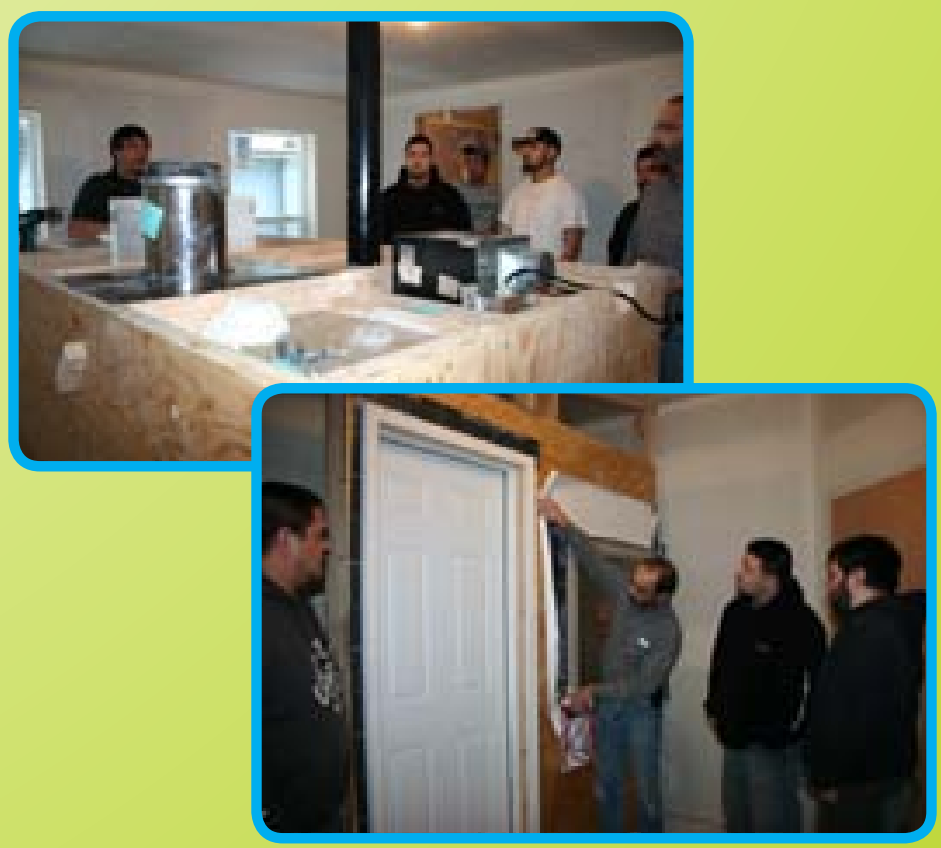

Applicants must pass the DOE Pre-training exam and provide driver's license. Training is supported by a grant from the Department of Energy. 


\section{FREE WEATHERIZATION TRAINING January 17 - 21, 2011}

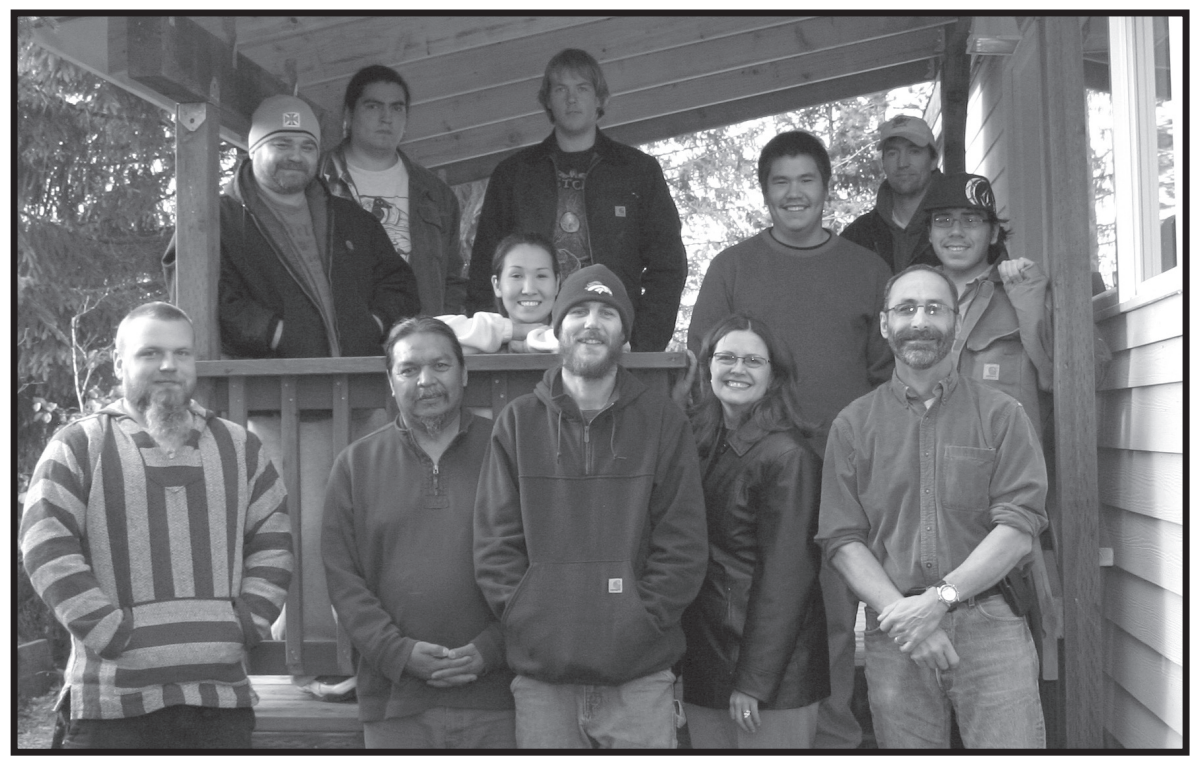

2010 Wx Training Graduates \& Program Staff

Tlingit-Haida Regional Housing Authority has partnered with the Central Council of the Tlingit and Haida Indian Tribes of Alaska to offer free weatherization training for Tribal Citizens.

Applicants who live outside the Juneau area in the southeast region may qualify for travel assistance.

Individuals completing the hands-on weatherization training may have the opportunity for employment with TlingitHaida Regional Housing Authority or other weatherization service providers.

Tlingit-Haida Regional Housing Authority helps families throughout Southeast Alaska improve home heating and energy efficiency.
FOR AN APPLICATION VISIT

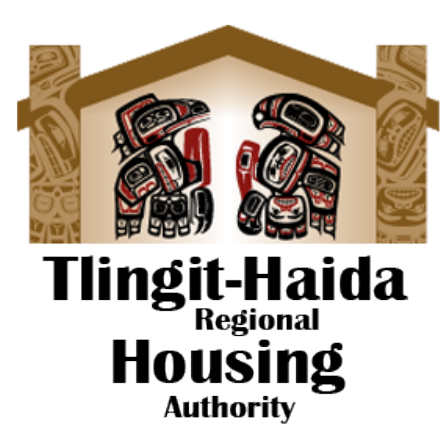

5446 Jenkins Drive (Near Costco) 907-780-6868 WWW.thrha.org 


\section{FREE WEATHERIZATION TRAINING January $17-21,2011$ Training}

\section{TRAINING INCLUDES}

Tribal Citizens completing the hands-on weatherization training may receive training that includes:

- Hands-on \& Technical Weatherization training.

- Blower door and airtightness workshops.

- AkWarm software weatherization training.

- Diagnostic procedures; heat loss, moisture identification, electrical safety, locating water damage.

- Cold Climate Advanced Homebuilder Workshop

- Ventilation Workshop

\section{KEY DATES TO REMEMBER}

- December 29, 2010 Deadline for applying for travel assistance (20 days prior to scheduled training).

- January 5, 2011 Complete the pre-training DOE test on or before 1/5/11.

- January 5, 2011 Deadline for submitting training application.

- January 10, 2011 You will be notified if we are able to offer you travel assistance (8 days prior to scheduled training).

- January 17 - 21, 2011 Attend Training in Juneau

\section{TO APPLY}

Applicants must provide copy of the following with their completed Native Weatherization Training Application:

- Pre-training test certificate

- Alaska Native Identification

- Drivers License

- Social Security card (required for training wages upon approval)

In advance of training, the applicant must be approved for attendance AND COMPLETE THE DEPARTMENT OF ENERGY PRE-TRAINING TEST. Trainee expenses must be approved and coordinated in advance by grant administration staff or management.

FOR AN APPLICATION VISIT

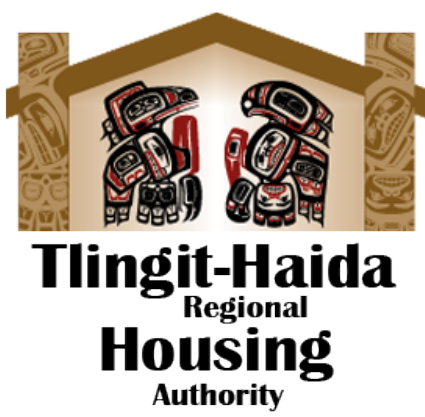

5446 Jenkins Drive (Near Costco) 907-780-6868 WWW.thrha.org

The Weatherization training program is made possible through the support of the Department of Energy, Central Council of Tlingit and Haida Indian Tribes of Alaska and Tlingit-Haida Regional Housing Authority. Expenses must be coordinated and approved by THRHA in advance and only reimbursable to training participant upon completion of training. Certificate of Training Completion is required with submittal of actual receipts for reimbursement. The daily class sign in/out sheet provides witness of attendance to validate expense reimbursement. 


\section{FREE WEATHERIZATION TRAINING SPRING CLASSES AVAILABLE}
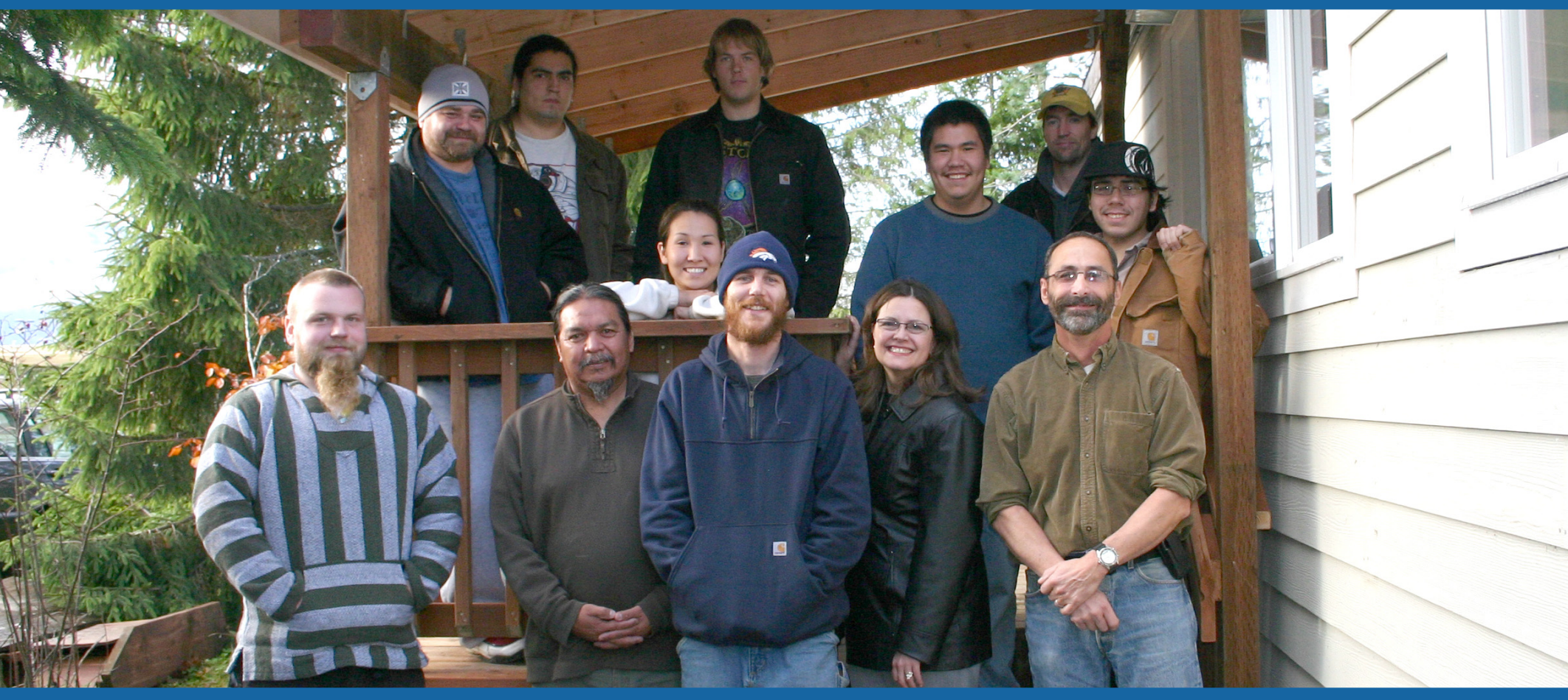

2010 Wx Training Graduates \& Program Staff

Tlingit-Haida Regional Housing Authority has partnered with the Central Council of the Tlingit and Haida Indian Tribes of Alaska to offer free weatherization training for Tribal Citizens.

Applicants who live outside the Juneau area in the southeast region may qualify for travel assistance.

Individuals completing the hands-on weatherization training may have the opportunity for employment with TlingitHaida Regional Housing Authority or other weatherization service providers. Tlingit-Haida Regional Housing Authority helps families throughout Southeast Alaska improve home heating and energy efficiency.
FOR AN APPLICATION VISIT

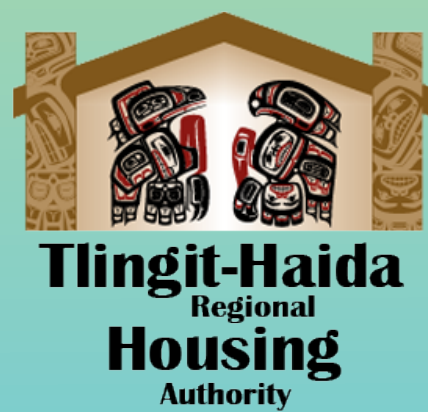

5446 Jenkins Drive (Near Costco)

907-780-6868

WWW.thrha.org 



\section{FREE WEATHERIZATION TRAINING January 17 - 21, 2011}
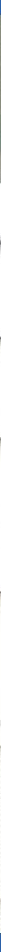

2010 Wx Training Graduates \& Program Staff

Tlingit-Haida Regional Housing

Authority has partnered

with the Central Council of

the Tlingit and Haida Indian

Tribes of Alaska to offer free weatherization training for Tribal Citizens.

Applicants who live outside the Juneau area in the southeast region may qualify for travel assistance.

Individuals completing the hands-on weatherization training may have the opportunity for employment with TlingitHaida Regional Housing Authority or other weatherization service providers.

Tlingit-Haida Regional Housing Authority helps families throughout Southeast Alaska improve home heating and energy efficiency.
FOR AN APPLICATION VISIT

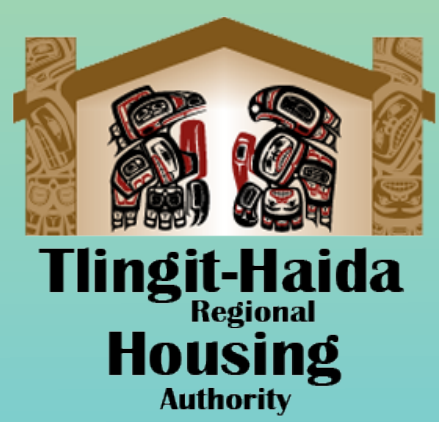

5446 Jenkins Drive (Near Costco)

907-780-6868

WWW.thrha.org 


\section{FREE WEATHERIZATION TRAINING January 17 - 21, 2011}

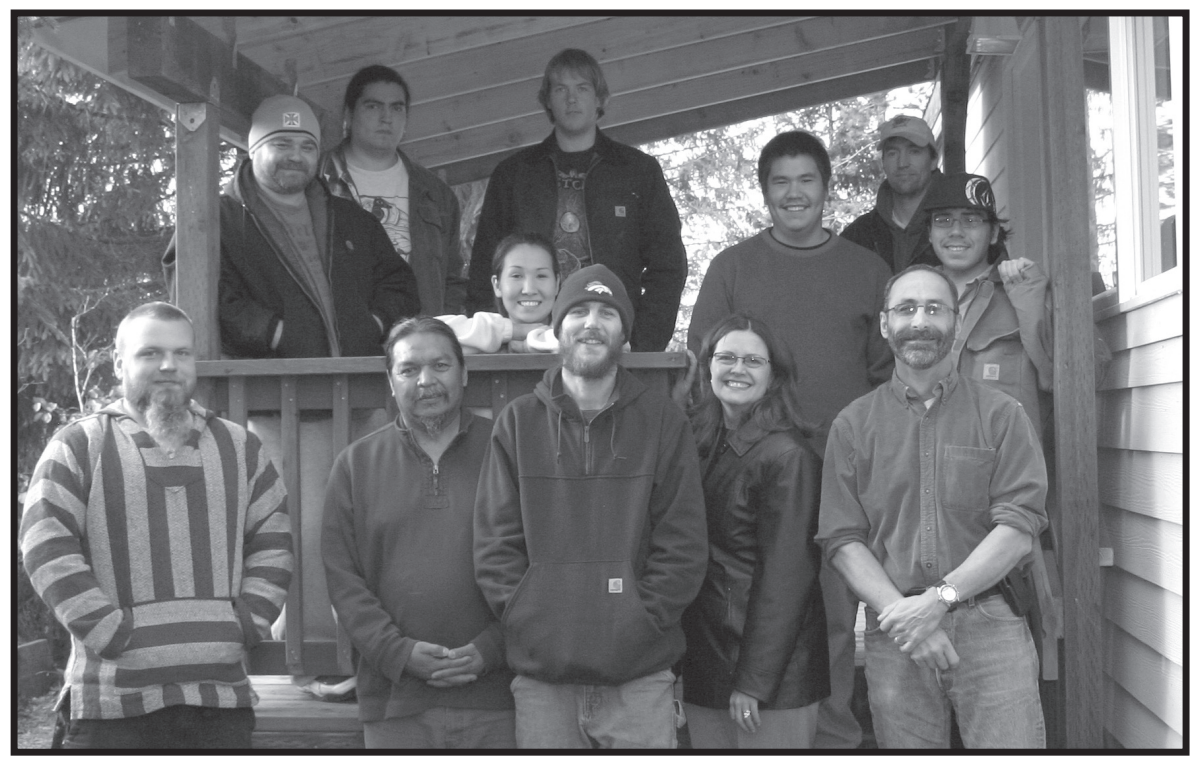

2010 Wx Training Graduates \& Program Staff

Tlingit-Haida Regional Housing Authority has partnered with the Central Council of the Tlingit and Haida Indian Tribes of Alaska to offer free weatherization training for Tribal Citizens.

Applicants who live outside the Juneau area in the southeast region may qualify for travel assistance.

Individuals completing the hands-on weatherization training may have the opportunity for employment with TlingitHaida Regional Housing Authority or other weatherization service providers.

Tlingit-Haida Regional Housing Authority helps families throughout Southeast Alaska improve home heating and energy efficiency.
FOR AN APPLICATION VISIT

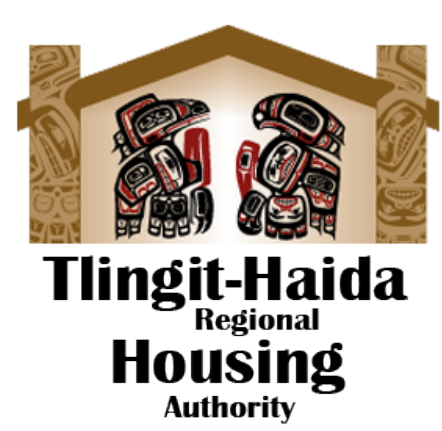

5446 Jenkins Drive (Near Costco) 907-780-6868 WWW.thrha.org 


\section{FREE WEATHERIZATION TRAINING January $17-21,2011$ Training}

\section{TRAINING INCLUDES}

Tribal Citizens completing the hands-on weatherization training may receive training that includes:

- Hands-on \& Technical Weatherization training.

- Blower door and airtightness workshops.

- AkWarm software weatherization training.

- Diagnostic procedures; heat loss, moisture identification, electrical safety, locating water damage.

- Cold Climate Advanced Homebuilder Workshop

- Ventilation Workshop

\section{KEY DATES TO REMEMBER}

- December 29, 2010 Deadline for applying for travel assistance (20 days prior to scheduled training).

- January 5, 2011 Complete the pre-training DOE test on or before 1/5/11.

- January 5, 2011 Deadline for submitting training application.

- January 10, 2011 You will be notified if we are able to offer you travel assistance (8 days prior to scheduled training).

- January 17 - 21, 2011 Attend Training in Juneau

\section{TO APPLY}

Applicants must provide copy of the following with their completed Native Weatherization Training Application:

- Pre-training test certificate

- Alaska Native Identification

- Drivers License

- Social Security card (required for training wages upon approval)

In advance of training, the applicant must be approved for attendance AND COMPLETE THE DEPARTMENT OF ENERGY PRE-TRAINING TEST. Trainee expenses must be approved and coordinated in advance by grant administration staff or management.

FOR AN APPLICATION VISIT

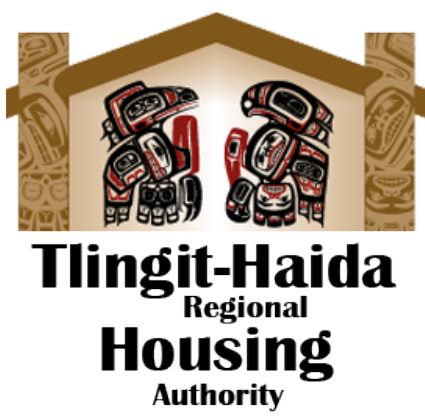

5446 Jenkins Drive (Near Costco) 907-780-6868 WWW.thrha.org

The Weatherization training program is made possible through the support of the Department of Energy, Central Council of Tlingit and Haida Indian Tribes of Alaska and Tlingit-Haida Regional Housing Authority. Expenses must be coordinated and approved by THRHA in advance and only reimbursable to training participant upon completion of training. Certificate of Training Completion is required with submittal of actual receipts for reimbursement. The daily class sign in/out sheet provides witness of attendance to validate expense reimbursement. 


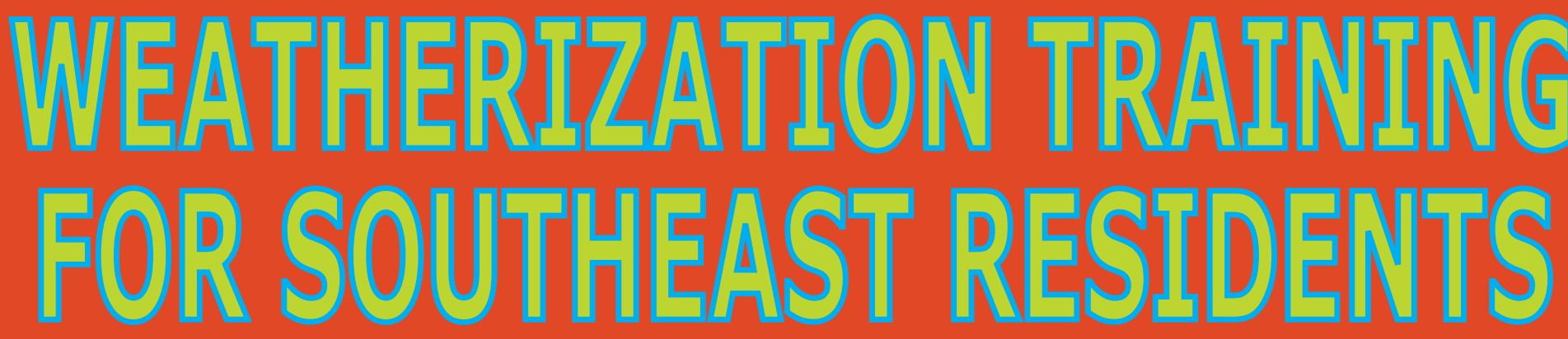

DEPARTMENT OF ENERGY WEATHERIZATION TRAINING OPPORTUNITY IIN JUNE⿱A口:

- April 2-6 WX Basic/Tech I

- May 21-25

\section{WX Advanced/Tech II}

Applicants must provide a copy of their DOE Pretraining test, driver's license and Social Security card (required for training wages upon approval). In advance of training, applicant must be approved for attendance and travel expenses. Weatherization Training Program graduates may be considered for employment with the THRHA or other Weatherization service providers.

\section{Hands-on weatherization training} may include:

- Blower door and airtightness

- AkWarm, weatherization software training

- Diagnostic procedures: heat loss, moisture identification, electrical safety, locating water damage

- Cold Climate Advanced Homebuilder Workshop

- Ventilation Workshop

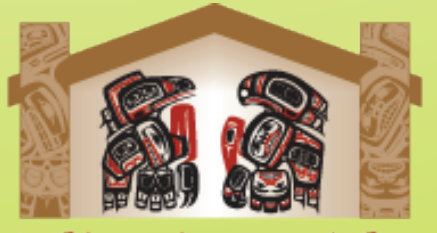

Tlingit-Haida Housing Authority

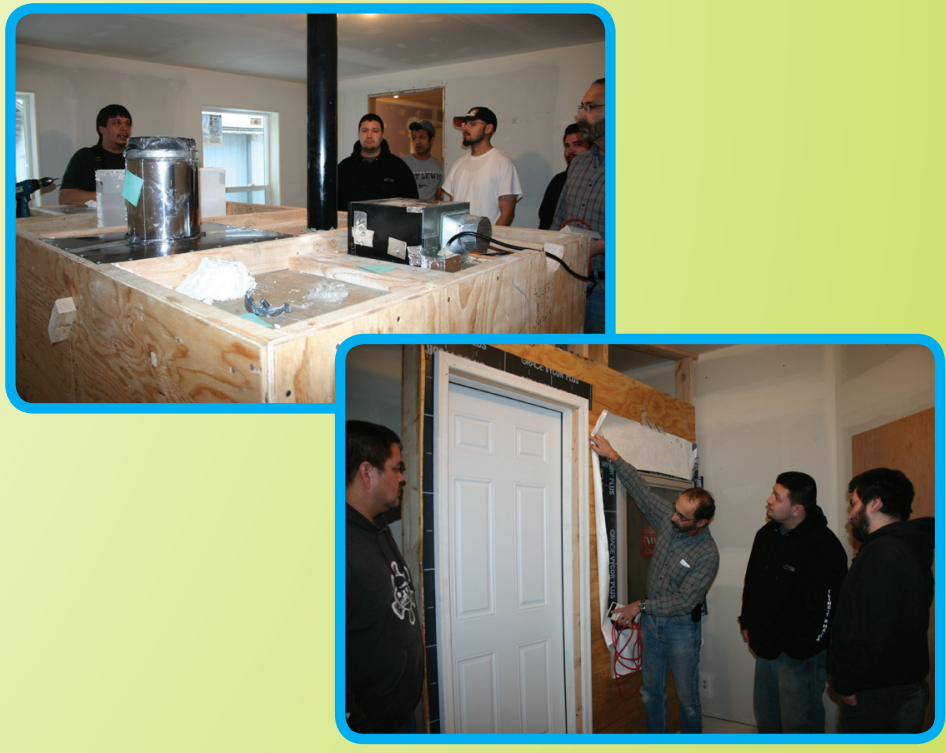

DOE Weatherization Training application must be submitted three (3) weeks prior to training date. Please submit training applications ASAP to be selected. A math pre-test is required before being selected for the training. Contact:

\section{Steve Bennett}

Training Coordinator sbennett@thrha.org

907-780-6868

\section{Tlingit-Haida} Regional Housing Authority

5446 Jenkins Drive (Near Costco in Juneau)
Helping Southeast Families Improve Hame Heating and Energy Efficiency 


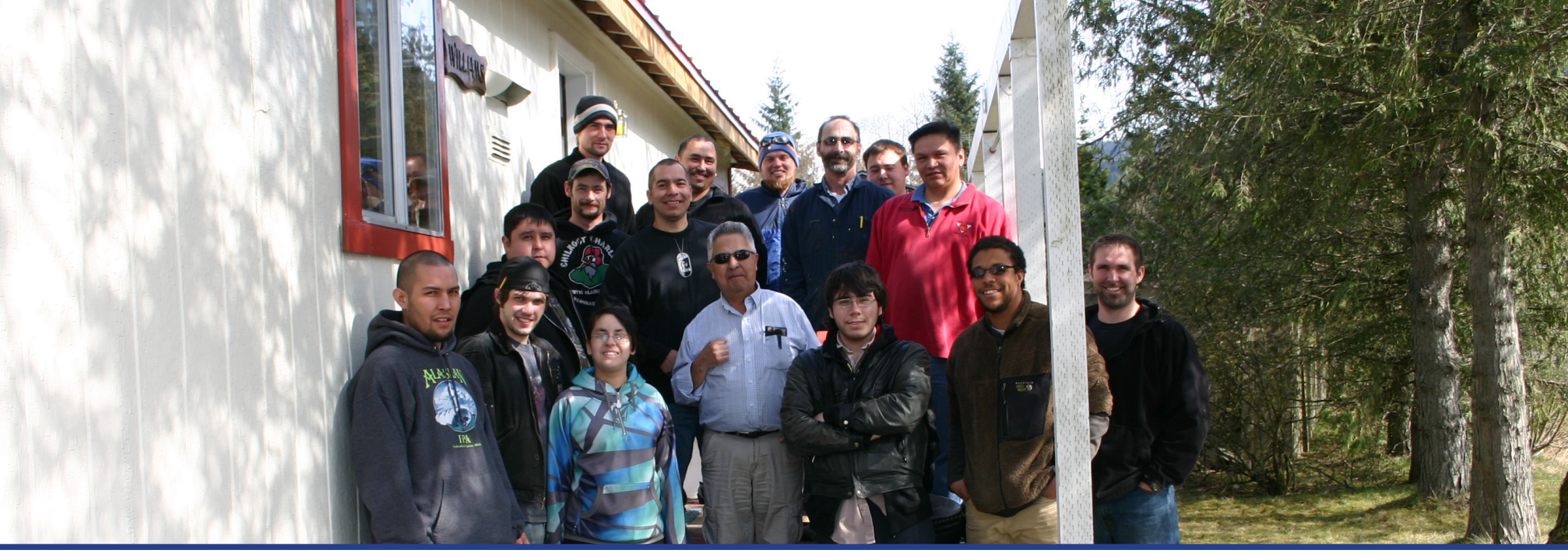

\section{Creating Green Jobs and a Bright Euture for Alaskans!}

The State of Alaska legislature appropriated Weatherization funding that has created employment opportunity throughout our State.

Weatherization providers are in need of trained weatherization workers and rural communities are in need of local employment.

Job training provided through an approved apprenticeship program creates multiple benefits: local employment, trained workers needed by weatherization providers and completion of home weatherization.

The Building Energy Retrofit Technician (BERT) apprenticeship program addresses the immediate need for training and job creation.

BERT meets the U.S. Department of Energy core competencies and the Building Performance Institute specifications and has been approved by the Alaska Housing Finance Corporation.

BERT has been submitted to the U.S. Department of Labor, Office of Apprenticeship for review and approval to become a registered apprenticeship in Alaska.

The BERT curriculum includes in-class, hands-on, and field trainings that effectively lead to apprenticeships and regional weatherization jobs, successfully weatherizing homes throughout Alaska.

We ask for your support and endorsement of the BERT apprentice program. Through your support, the U.S. Department of Labor, Office of Apprenticeship will endorse the BERT program as a Federal recognized apprentice program that is needed in Alaska.

We thank you for your efforts and support of the BERT Apprentice program that is uniquely designed specifically to the urgent needs of Alaskans.
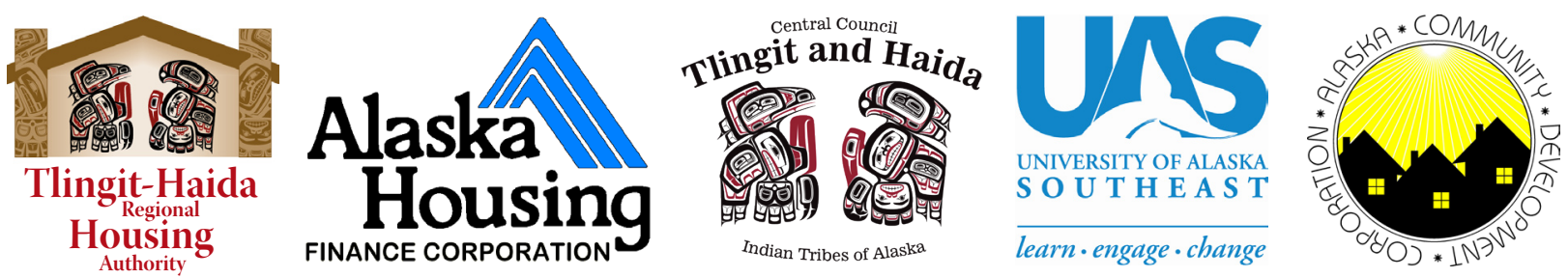


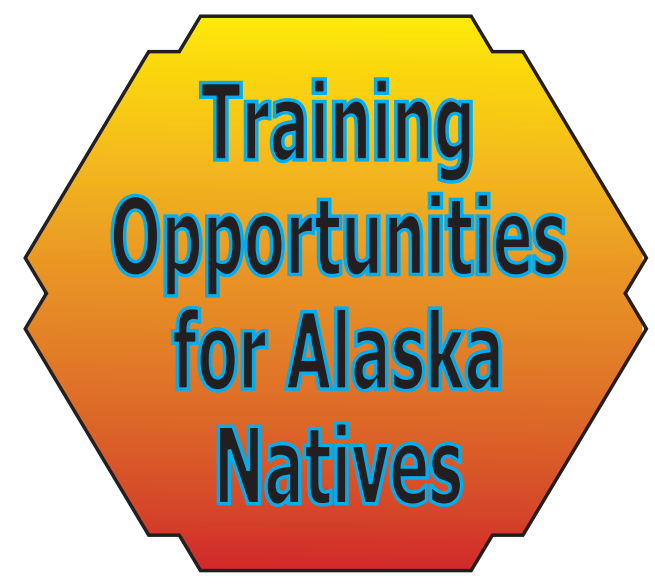




\section{Appendices 5}

Articles / News (Example) 


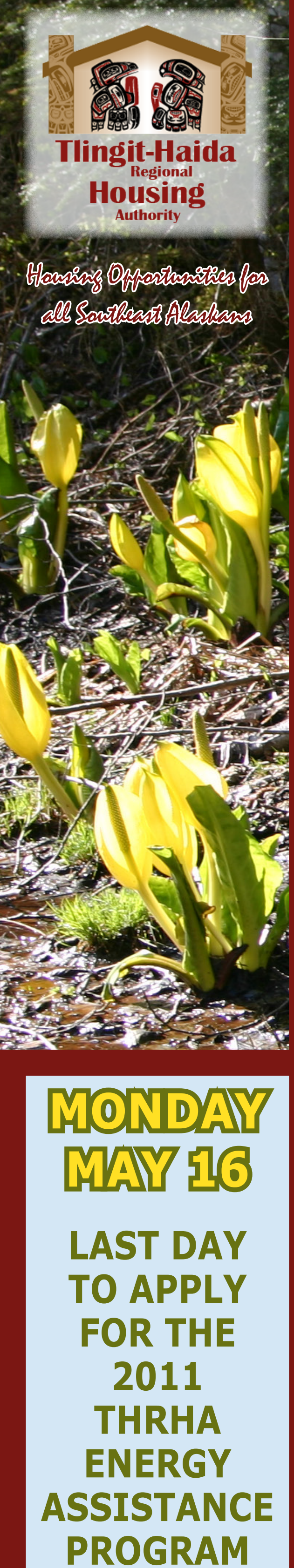

The federally funded LIHEAP Program provides a one-time benefit to eligible households that fall within the 150 percent Alaska poverty level with home energy heating costs. The amount of the benefit is determined by household income, household size, fuel type, and geographic location.

TO QUALIFY, YOU MUST - Complete the THRHA Energy Assistance Program application. - Meet income guidelines. - Assistance may apply to heating or electric bill.

\section{THRHA Update}

April 28, 2011

\section{Weatherization Training Program}

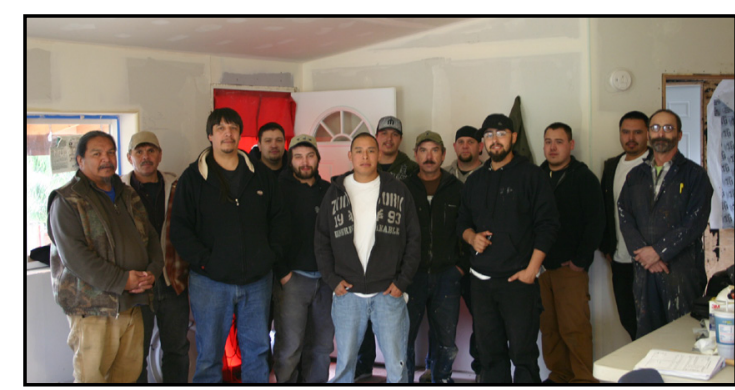

Last week 12 more Tribal Citizens graduated from the THRHA Weatherization Training program at the THRHA Weatherization Training Center in Juneau. A total of 59 Southeast residents have participated in the program and more Paul Aceveda, Anthony Durgan, Marvin Willard Jr., Dustin Stevenson, Wilbur Skeek, Jamieson Williams, Sonny Willard, Robert Brooks, Brent and Marquam George instructor.

than 60 percent have been hired by THRHA or other weatherization service providers. Classes are

ongoing, visit www.thrha.org more information.

\section{Kake Energy Workshop and Fair}

THRHA co-hosted an Energy Workshop and Energy Fair with the Organized Village of Kake. Representatives from a variety of state and federal agencies presented on Kake's energy situation and future. The two-day event was well attended. Residents of Kake (and all over southeast) are struggling to pay for fuel, over $\$ 5.26$ per gallon, and skyrocketing food bills. Communities are reaching out to find solutions to the crisis.

Representative from THRHA were on hand to discuss and share energy saving tips and products to help lower energy usage. Currently, THRHA is working on a new incentive program to encourage tenants to lower energy usage.

Consider hosting a similar event in your community.

\section{HR 1473: How it affects THRHA}

Now that the threat of a government shutdown has passed and Washington finally passed a spending plan for the remainder of $\mathrm{FY}$ 2011, one might ask how it affects THRHA? HR 1473 includes $\$ 650$ million for the Native American Housing Block Grant program, a decrease of $\$ 50$ million below FY 2010. In perspective, this equals seven percent funding cut for THRHA. The bill also includes $\$ 65$ million for the Indian Housing Block Grant Program, within the Community Development Fund. This level of funding is equal to the FY 2010 level.

THRHA is more concerned that a fair and reasonable budget is passed for FY 2012. Our hope is that Indian Housing/NAHASDA funding remain at the $\$ 700$ million level. Any significant funding cuts will greatly impact housing programs and policy.

For the past several years, the National budget process has been unpredictable. Year after year, the threat of government shutdowns and budget cuts has inspired THRHA to prepare for the worst and plan for the best. THRHA is financially stable and will continue to strategically plan for the future budget cuts.

Your cooperation is greatly appreciated. Please keep yourself informed of our national policy and contact your representatives to voice your concerns.

http://murkowski.senate.gov/public/

http://donyoung.house.gov/public/

http://begich.senate.gov/public/

(1)

Proud sponsor of the spring King Salmon Derby

Supporting youth through scholarships and affordable housing opportunities Rentals $\cdot$ Homeownership - Weatherization Energy Assistance $\bullet$ Student Housing Weatherization Training

Serving Southeast Alaska Since 1973 5446 Jenkins Drive, Juneau, AK 99801 907-780-6868 www.thrha.org

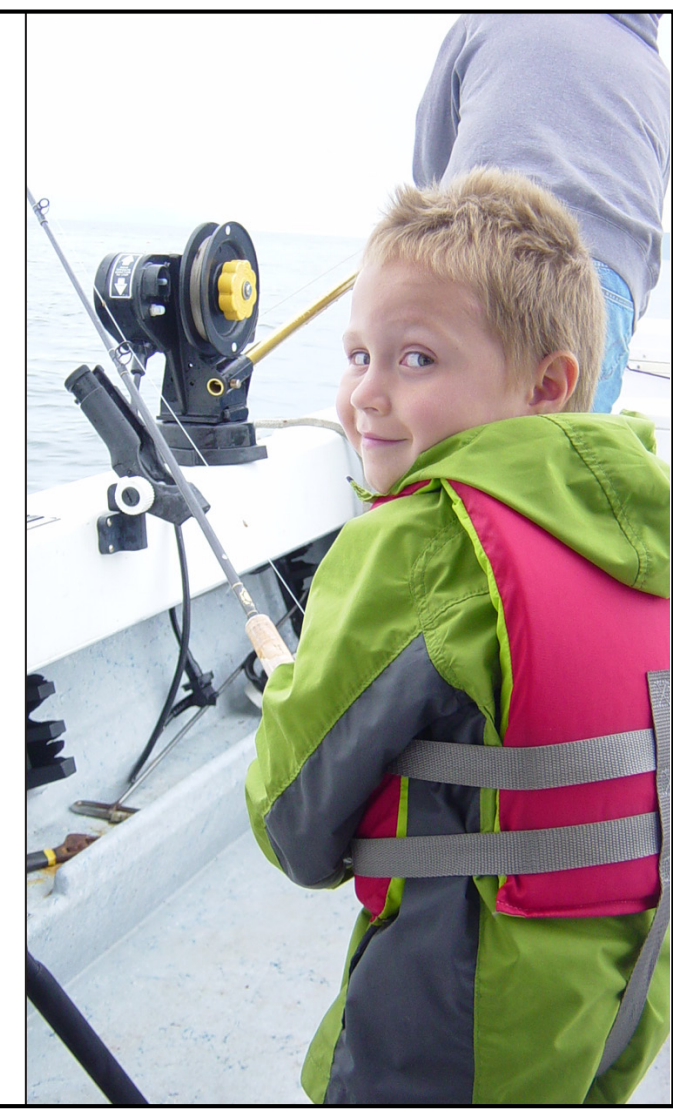

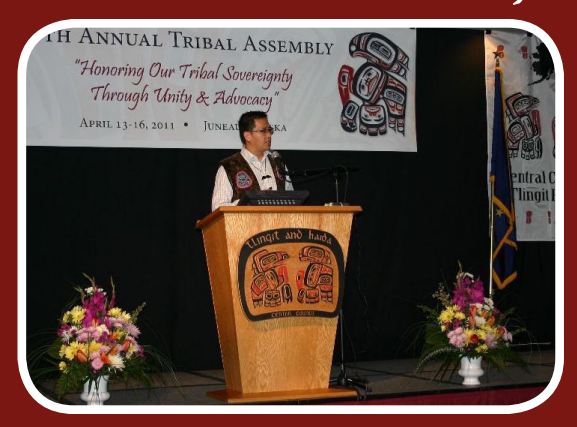

Tribal Assembly, Juneau.

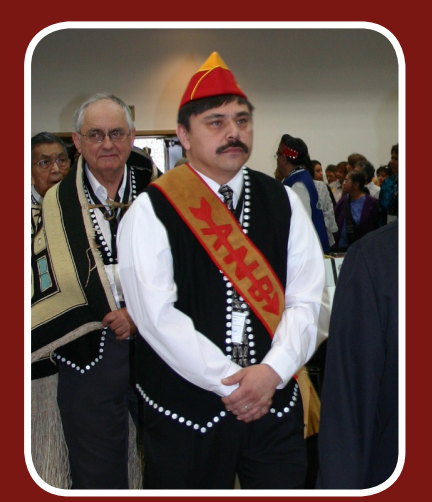

Harold Houston, THRHA Procurement Officer, participates in the 76th Tribal Assembly, Juneau. Harold Serves on the CCTHITA Executive Council.

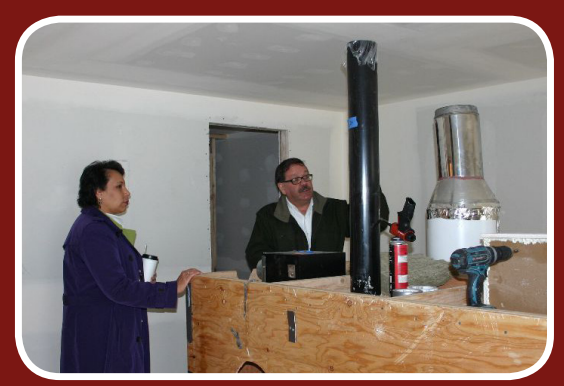

Vice President Criag Moore tours THRHA Weatherization Training Center with Tracy LaBeau, Director for the U.S. Department of Energy's Office of Indian Policy and Programs. The training center
was funded in-part by a grant from the was funded in-part by a grant from $t$
Department of Energy. Ms. LaBeau also spoke at the 76th Tribal Assembly, Juneau.

Criag Moore will be speaking at the U.S. Department Of Energy Tribal Summit in Arlington, May 4-5, 2011. http://www.energy.gov/indianenergy/

\section{trihnicummit htom

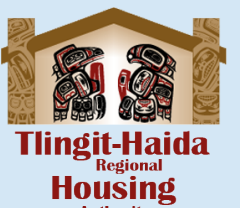 \\ CONTACT INFORMATION: \\ (907) 780-6868 \\ Fax (907) 780-6895 PO Box 32237 Juneau, AK 99803-2237 5446 Jenkins Drive \\ (Near Costco in Juneau) www.thrha.org}

REGULAR BUSINESS HOURS

Monday - Friday 8:00 AM to 4:30 PM Saturday \& Sunday Closed

SUMMER HOURS BEGIN Tuesday, May 31

Monday - Thursday 8:00 AM to 5:00 PM Friday

8:00 AM tol:30 PM Saturday \& Sunday Closed

THRHA HOLIDAY Monday, May 30

Memorial Day THRHA Offices Closed

THRHA is an Equal Opportunity Employer/Programs 


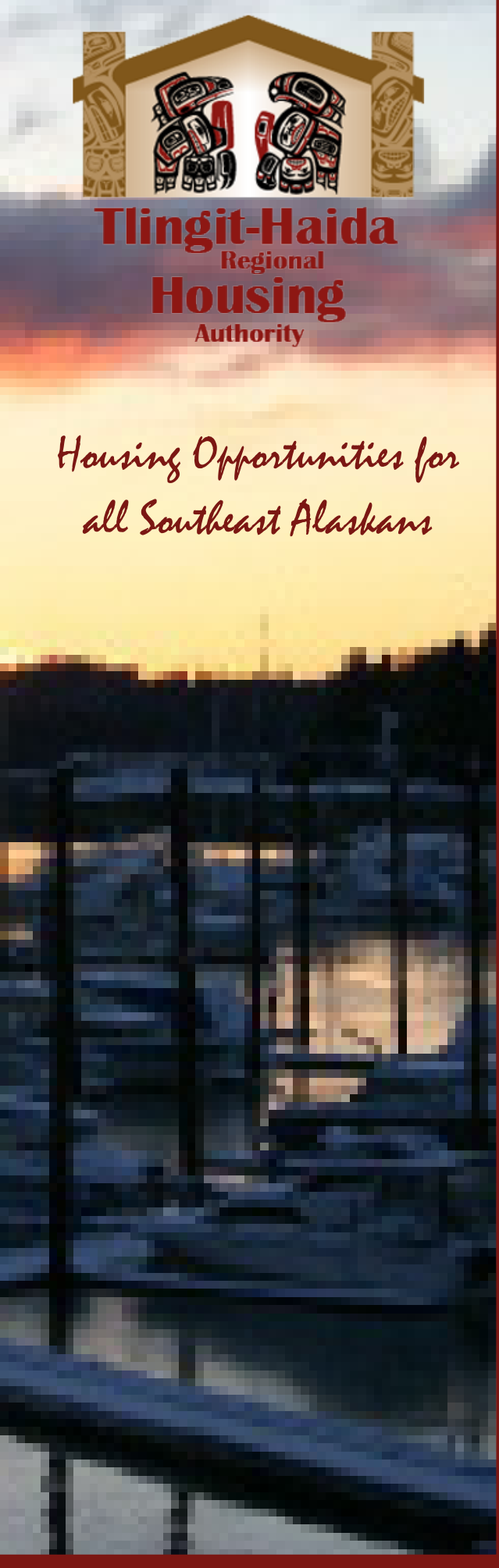

Win 12,500

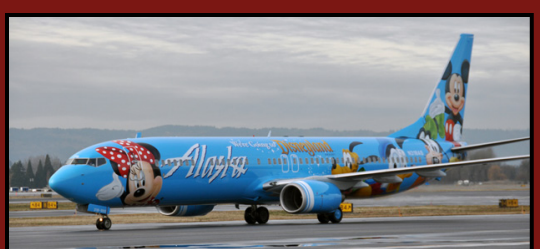

\section{Alaska Air Miles}

Give us your email address for the opportunity to win 12,500 Alaska Air Miles!

Go to thrha.org, click on Alaska Air Miles Give Away and complete the form. Providing THRHA with your email address will help keep you informed on the latest news and programs.

The Alaska Air Miles drawing will be March 31, 2011.

\section{THRHA Update}

March 11, 2011

THRHA Participates in SEABIA Home Show - For the past several years, THRHA has participated in the Southeast Alaska Building Industry Association's

Home Show at the

Centennial Hall in Juneau, highlighting housing and construction programs. This past weekend, staff was on hand to answer questions and distribute a variety of housing program information and applications, including the Weatherization program.

In 2008, the Alaska Legislature passed a bill that created a statewide weatherization and

energy efficiency program, administered through the Alaska Housing Finance Corporation. THRHA is the certified provider exclusively serving Angoon, Craig, Hoonah, Hydaburg, Kake, Kasaan, Klawock, Petersburg, Saxman, Yakutat, and shares the Juneau City and Borough area with RuralCap. The program provides up to $\$ 10,000$ of home heating and energy efficiency repairs for income eligible residents. Some may qualify for preferences, 55 years of age and older disabled, or living with children under age six. However no Native preference applies for this program. With generous income limits a family of four residing in most Southeast communities may earn up to $\$ 71,900$, in Juneau $\$ 91,000$, and Ketchikan $\$ 79,200$. Usually each year, by the end March, income limits are slightly adjusted and published. So far no adjustments have been made this year.

Complete your application on line at www.thrha.org or visit our office at 5446 Jenkins Drive, near Costco in Juneau. Apply today and you can lower your utility bills by approximately 20 percent. One in four homes are now saving up to 37 percent in home heating costs. At the end of the five-year funding period, THRHA will have serviced over 1,000 homes.

THRHA Weatherization Training Program - In partnership with Central Council Tlingit and Haida Indian Tribes of Alaska,

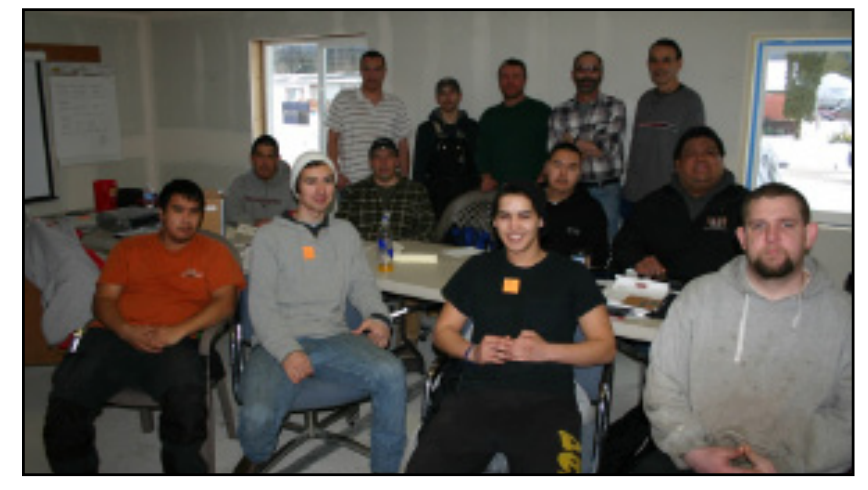

2011 THRHA Weatherization Training Program participants and staff at the THRHA Weatherization Training Center in Juneau. the program, nearly a hundred new crew, with more than half taking advanced courses and completing the various certification for the specialized equipment and computer programs. Nearly 100 percent of the graduates are working in the field either with THRHA or with other weatherization service providers.

\section{Introducing Cassandra Bell,}

THRHA's new DCM Administrative Assistant. "I'm very excited to have joined the Tlingit and Haida Regional Housing Authority team and look forward to working with you". Cassandra can be reached at (907) 780-3132 or fax (907) 7806253, cbell@thrha.org.

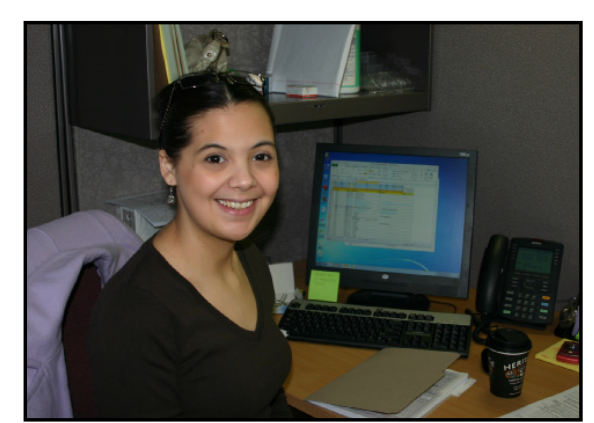

Fireweed Place Hosts Weavers' Workshop - THRHA's Fireweed Place, a senior independent living apartment building in downtown Juneau, has been hosting weekly weavers' workshops in their day room. Follow the link to read more about the program and how to participate.

Teachers learn, students teach at Fireweed Place weaving group led by Della Cheney, story by Amy Fletcher of the Juneau Empire.

http://www.juneauempire.com/stories/030311/art_793671697.shtml

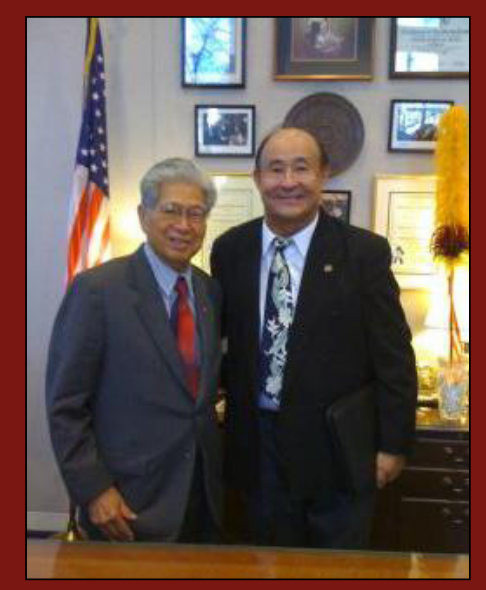

Hawaii Senator Akaka and THRHA President Dr. Blake Kazama recently visited in Washington D.C. to discuss funding issues. Senator Akaka is Chairman of the Indian Affairs Committee and also serves on the Housing and Urban Affairs Committee.

With the fiscal crisis and the unpredictability in Washington, it is ever more critical that THRHA maintains a positive relationship with members of Congress. Hopefully Congress will pass a

"Continuing Resolution" and funding will stay the same as last year.

\section{Doyylighthis}

\section{Sovvings}

Itine

\section{bอg]|ก:}

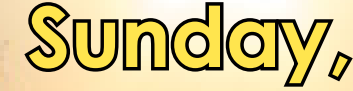 \\ MAdren 13.}

of $2 \mathrm{AM}$. Spring :-

ahead by

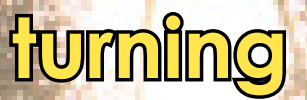
your aloek forwon] one hour. 


\section{Congratulations to Louise Kadinger and Martha} McKinley for another successful funding period for the THRHA Energy Assistance Program. As of the close of the application period, Monday, May 16, they have processed 1,641 applications for assistance with home energy heating costs to eligible households that fall within 225 percent of the Alaska poverty level. The amount of the benefit is determined by household income, household size, energy type, and geographic location. The 2012 application period will open Tuesday, November 1 for seniors, age 55 and older, and for all others Wednesday, December 1, 2011.

THRHA Board of Commissioners will hold its quarterly meeting Friday, June 10, 2011, 9 AM at the THRHA Convention Center, 5446 Jenkins Drive, Juneau.

Summer Hours Begin, Tuesday, May 31. Hours are Monday through Thursday, 8:00 AM to 5:00 PM; and on Fridays 8:00 AM to 1:30 PM.

Memorial Day, Monday, May 30, THRHA offices will be closed.

\section{Training Opportunity for Tribal Citizens}

THRHA is offering a Basic Weatherization Training at the THRHA Weatherization Training Center in Juneau, July 11 - 15, 2011.

Training may include: hands-on and technical weatherization training; blower door and airtightness workshops; AkWarm software weatherization training; diagnostic procedures: heat loss, moisture identification, electrical safety, locating water damage.

Tribal Citizens may contact Steve Bennett, Training Coordinator, at 907-780-6868 to schedule a Department of Energy Pre-training Test, and a Native Weatherization Training Application. Applicants must provide a copy of their Alaska Native Identification, Drivers License, and Social Security card (required for training wages upon approval). In advance of training, applicant must be approved for attendance and trainee expenses by grant administration staff or management. Tribal Citizen residing in Southeast may qualify for travel assistance. Weatherization Training Program graduates may be considered for employment with the THRHA Weatherization Program.
THRHA

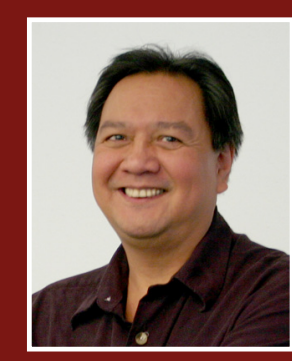

Michael Corpuz Chairman Juneau
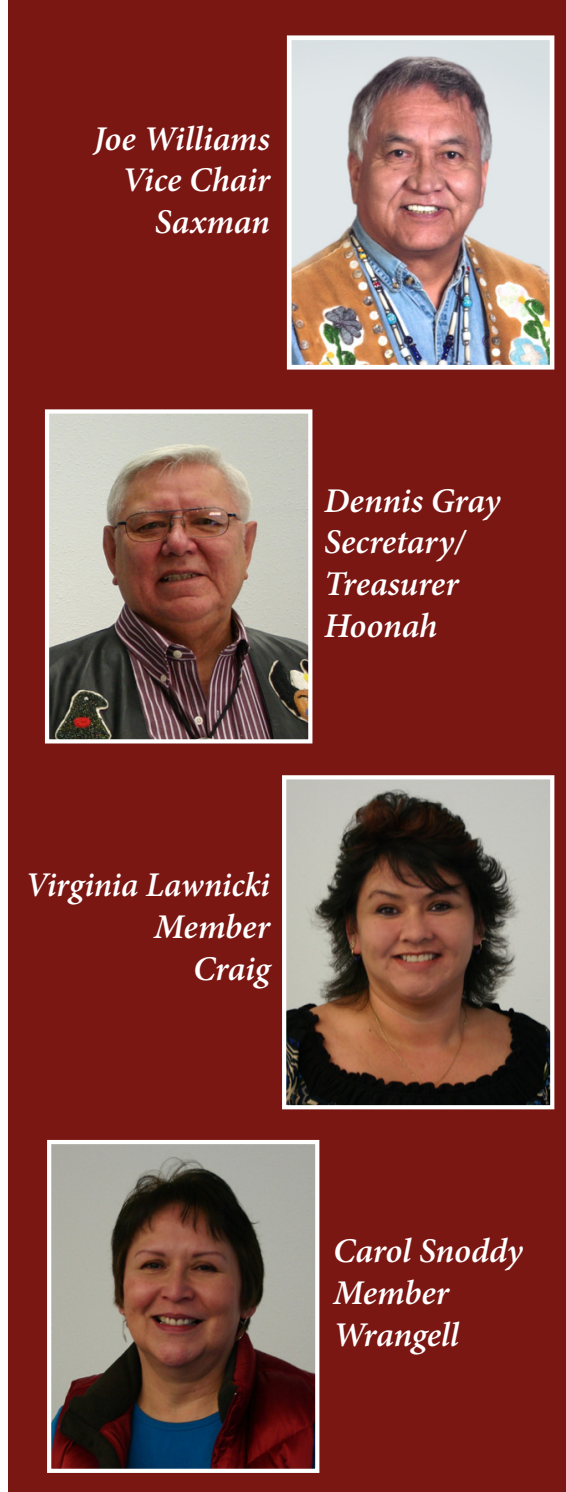


\section{THRHA Undate}

May 3, 2011

\section{THRHA BOARD OF COMMISSIONERS}

THRHA Board of Commissioners wear many hats. In addition to regular jobs and community activities, the five member board volunteers to serve a three year term on THRHA's Board of Commissioners. Chairman Michael Corpuz works for the Alaska Marine Highway System and is also a delegate for Central Council Tlingit and Haida Indians of Alaska. Vice Chair Joe Williams is busy gearing up for the summer visitor season. He owns and operates "Where the Eagle Walks", a walking-tour company in Ketchikan. Secretary/Treasurer Dennis Gray, now retired, serves on the Hoonah Indian Association Board, a delegate for Central Council Tlingit and Haida Indian Tribes of Alaska, and a life-time member of the Alaska Native Brotherhood. Carol Snoddy volunteers for the Tlingit \& Haida Roads Elder History Project, the Wrangell Chamber of Commerce, the SDA Foods Distribution, Alaska

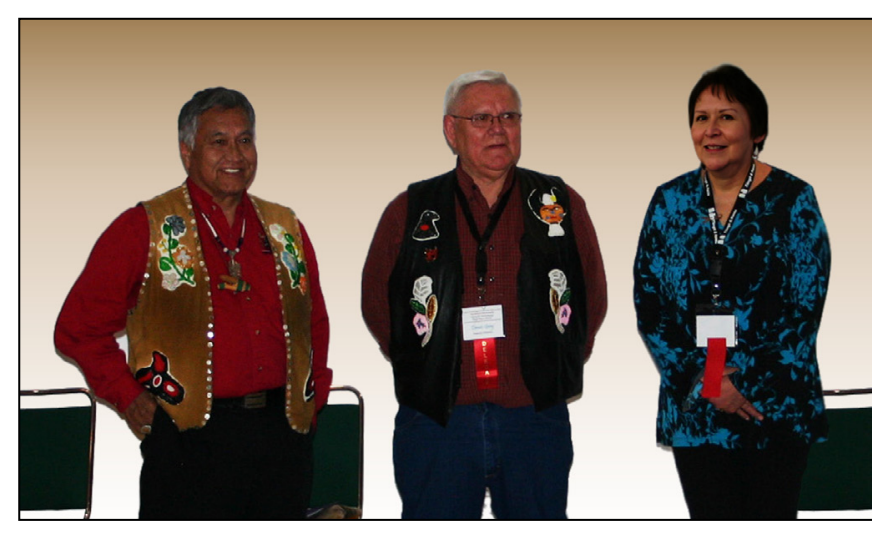

THRHA Board of Commissioners Joe Williams (Saxman), Dennis Gray (Hoonah), Carol Snoddy (Wrangell), participated in the 76th Tribal Assembly, April 13 - 16, 2011, in Juneau. Virginia Lawnicki (Craig) was unable to attend due to a prior commitment.
Alaska Native Sisterhood, Camp 19. Virginia is currently employed with the City of Craig.

We appreciate their service and dedication to their communities. Gunalchéesh Háw'aa.

\section{TRIBAL CITIZEN TRAINING OPPORTUNITY}

THRHA is offering a Basic Weatherization Training at the THRHA Weatherization Training Center in Juneau, July $11-15,2011$.

Training may include:

- Hands-on and technical weatherization training

- Blower door and airtightness workshops

- AkWarm software weatherization training

- Diagnostic procedures; heat loss, moisture identification, electrical safety, locating water damage

- Cold Climate

Advanced

Homebuilder

Workshop

- Ventilation

Workshop

Tribal Citizens may contact Steve Bennett, Training Coordinator, at

907-780-6868

to schedule a

Department of Energy Pre-training Test, and a Native Weatherization Training Application. Applicants must provide a copy of the following:

- Alaska Native Identification

- Drivers License

- Social Security card (required for training wages upon approval) In advance of training, applicant must be approved for attendance and trainee expenses by grant administration staff or management. Tribal Citizen residing in Southeast may qualify for travel assistance. Weatherization Training Program graduates may be considered for employment with the THRHA Weatherization Program. demonstrates cold climate building techniques at the THRHA Weatherization Training Center in Juneau. Students $(R-L)$ are Dustin Stevenson, Wilbur Skeek, and Marvin Willard Jr.

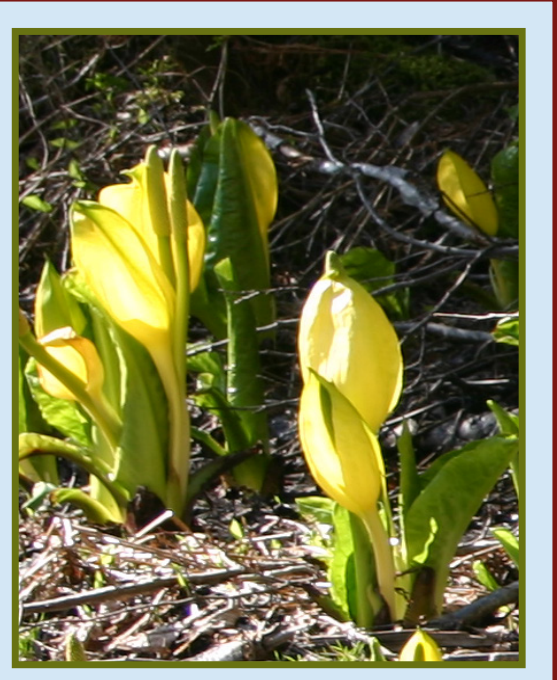

MONDAIY MA1Y516

LAST DAY TO APPLY FOR THE 2011 THRHA ENERGY

\section{ASSISTANCE}

\section{PROGRAM}

The federally funded LIHEAP Program provides a one-time benefit to eligible households that fall within the 150 percent Alaska poverty level with home energy heating costs. The amount of the benefit is determined by household income, household size, fuel type, and geographic location.

TO QUALIFY, YOU MUST - Complete the THRHA Energy Assistance Program application and submit supporting documents.

- Meet income guidelines.

- Assistance may apply to heating or electric bill.

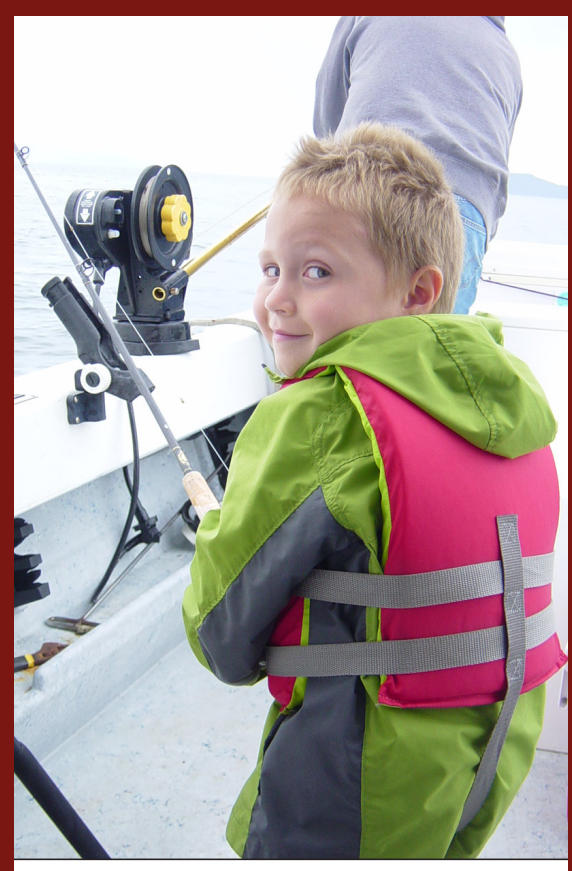

Proud sponsor of the

spring King Salmon Derby

Marquam George (center), Weatherization Training Instructor

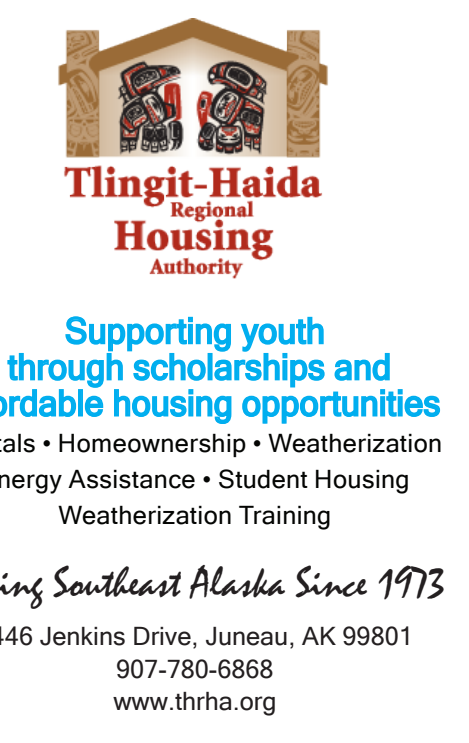




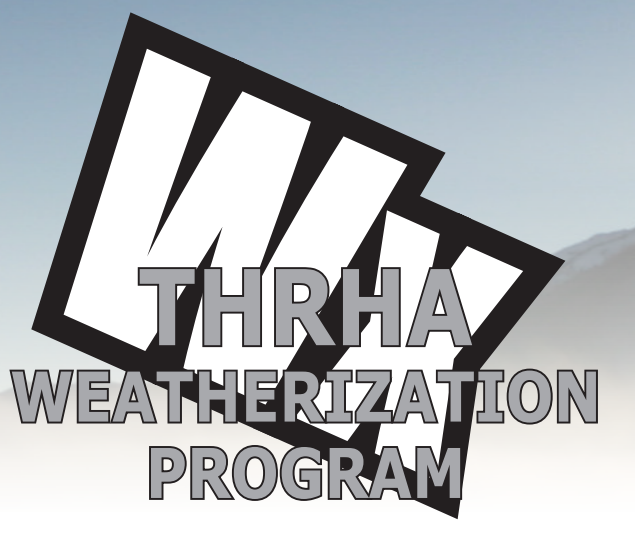

hanks to THRHA, homeowner John Charles of Klawock, can now let his grandchildren play on the floor. Like many other Southeast families his home desperately needed weatherization repairs to improve energy efficiency. By adding more insulation to the floors, replacing drafty windows and doors, and updating the heating system made a big difference for the comfort of his home, work that he could not afford to make on his own. "Now I don't have to make threats to keep my family from touching the thermostat," John said with a smile on his face.

In addition to weatherizing homes, THRHA sought funding for training programs

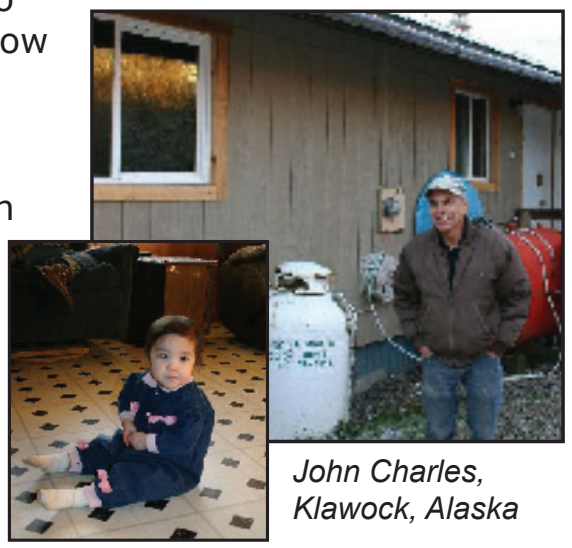

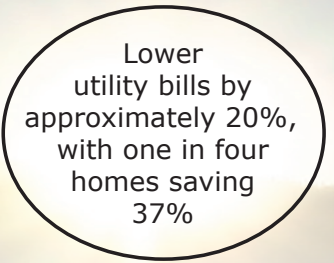

\section{Helping Southeast families improve hame beating and energy efficiency}

to develop the specialized crews to complete weatherization repairs. THRHA was award several training grants from the U.S. Department of Energy, U.S. Department of Labor, Alaska Housing Finance Corporation, and First Bank, and others.

THRHA changes lives while helping create economic stability in S.E. communities.

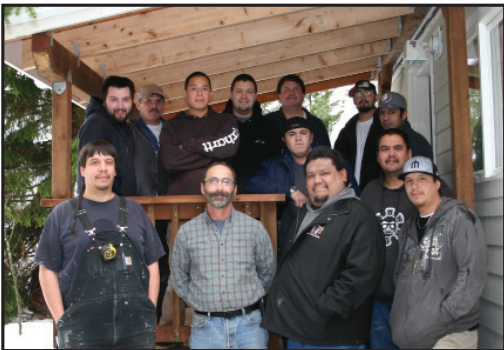

2011 THRHA Weatherization Training Program participants and staff at the Juneau Training Center.
Antoine Smith, a

single-father of four, can now work in his home community and be available for his family. Communities throughout Southeast have benefitted from having trained crews working and helping the people in their communities.

If you meet income guidelines, you may qualify to have your home weatherized at no cost. You may also qualify for preferences if you are age 55 and over, disabled, or live with children under age six.

THRHA WEATHERIZATION AND ENERGY EFFICIENCY PROGRAM INCOME LIMITS (Effective March 2010)

\begin{tabular}{|c|c|c|c|c|c|c|c|c|}
\hline COMMUNITIES & $\begin{array}{c}1 \\
\text { Person }\end{array}$ & $\begin{array}{c}2 \\
\text { Persons }\end{array}$ & $\begin{array}{c}3 \\
\text { Persons }\end{array}$ & $\begin{array}{c}4 \\
\text { Persons }\end{array}$ & $\begin{array}{c}5 \\
\text { Persons }\end{array}$ & $\begin{array}{c}6 \\
\text { Persons }\end{array}$ & $\begin{array}{c}7 \\
\text { Persons }\end{array}$ & $\begin{array}{c}8 \\
\text { Persons }\end{array}$ \\
\hline Juneau Borough & 63,700 & 72,800 & 81,900 & 91,000 & 98,300 & 105,600 & 112,900 & 120,200 \\
\hline $\begin{array}{c}\text { Saxman (Ketchikan Gateway } \\
\text { Borough) }\end{array}$ & 55,500 & 63,400 & 71,300 & 79,200 & 85,600 & 91,900 & 98,300 & 104,600 \\
\hline $\begin{array}{c}\text { Angoon, Craig, Hoonah, } \\
\text { Hydaburg, Kake, Kasaan, } \\
\text { Klawock, Petersburg, Yakutat }\end{array}$ & 50,400 & 57,600 & 64,800 & 71,900 & 77,700 & 83,500 & 89,200 & 95,000 \\
\hline
\end{tabular}

\title{
Housing Opportunities for all Southeast Alaskans
}

\author{
APPLY ONLINE TODAY! \\ www.thrha.org \\ or stop by 5446 Jenkins Dr. \\ 780-6868
}

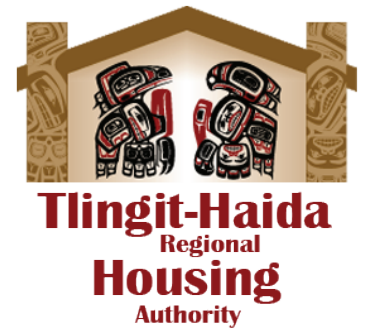




\section{Appendices 6}

Attendance Form / Pre - Post Test (Examples) 
CONSTRUCTION TECHNOLOGY

VTEC024-J01 - Weatherization

Sign-in sheet:

Date: 20 September 2010

1. Fred Smith

2. Ora Schoonover

3. Sari Jo Bottler

4. Justin Jackson

5. Shane Hemming

6. Matthew Bell

7. Marvin willerdje

8. Richard Standish

9.

10.

11.

12. 
CONSTRUCTION TECHNOLOGY

VTEC024-J01 - Weatherization

Sign-in sheet:

Date: 21 September 2010

1. Fredrick Smith 8:00 an

2. Ora Schounow

3. Sari so Bottler

4. Justin Jackson

5. Shane Hemming

6. Matthew Be

7.

8. Midland Stander

9.

10.

11.

12. 
CONSTRUCTION TECHNOLOGY

VTEC024-J01 - Weatherization

Sign-in sheet:

Date: 22 September 2010

1. Frolick Snik

2. Ora Schoonour

3. Sami so Bottlen

4. Justin JAckson

5. Shane Hemmings

6.

7.

8. Richand 5 tanelos

9.

10.

11.

12. 
CONSTRUCTION TECHNOLOGY

VTEC024-J01 - Weatherization

Sign-in sheet:

Date: 23 September 2010

1. Fiedrick Snith

2. Ora Schoonar

3. Sami Jobouler

4. Tustin Jackson

5. Shane Hemmings

6. Matthew Ball

7. Maruin willerd sie

8. Riduad Stand is

9.

10.

11.

12. 
CONSTRUCTION TECHNOLOGY

VTEC024-J01 - Weatherization

Sign-in sheet:

Date: 24 September 2010

1. Fredrick saith

2.

3. Semi Jo Bottler

4. Justin Jackson

5. Share Hemming s

6.

7. Marvin willard $\pi$

8. Richard Standish

9.

10.

11.

12. 


\section{DOE Training Acceptance Requirement \\ Math Pre-Test}

You may use a calculator to solve the following questions. Answers may be expressed in decimal or fraction form. (15-minute time limit)

You must score 73\% or higher, (answer at least eleven (11) out of fifteen (15) correct). Failure to do so will require additional basic math skills before attending the Initial Inspection course at the OWTC.

1. $81 / 2^{\prime \prime}$

$173 / 4 "$

$+233 / 8 ”$
2. $231 / 4 ”$

$-71 / 8^{\prime \prime}$
3. $\quad 23.25$

$\underline{\times 12.75}$

4. $350 / 40=$

5. $3 / 8 \times 120=$

6. How many inches are in 5 feet?

7. One square foot equals how many square inches?

8. What is the perimeter of the house diagramed below? feet.

9. What is the area of the house diagramed below? square feet.

10. What is the volume of the house diagramed below? cubic feet.

11. What is $75 \%$ of 2400 ?

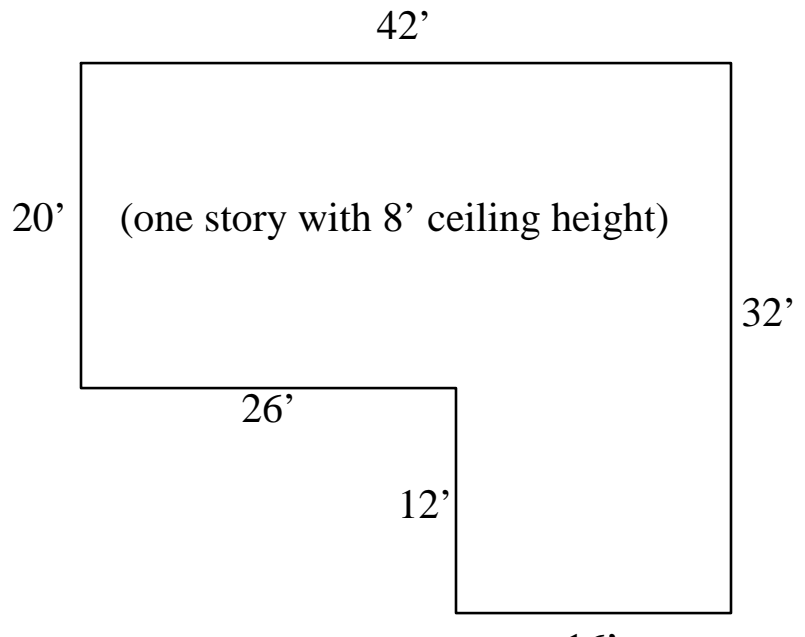

$16^{\prime}$ 
12-15. Write in the measurement indicated by the arrow pointing at the tape measure.

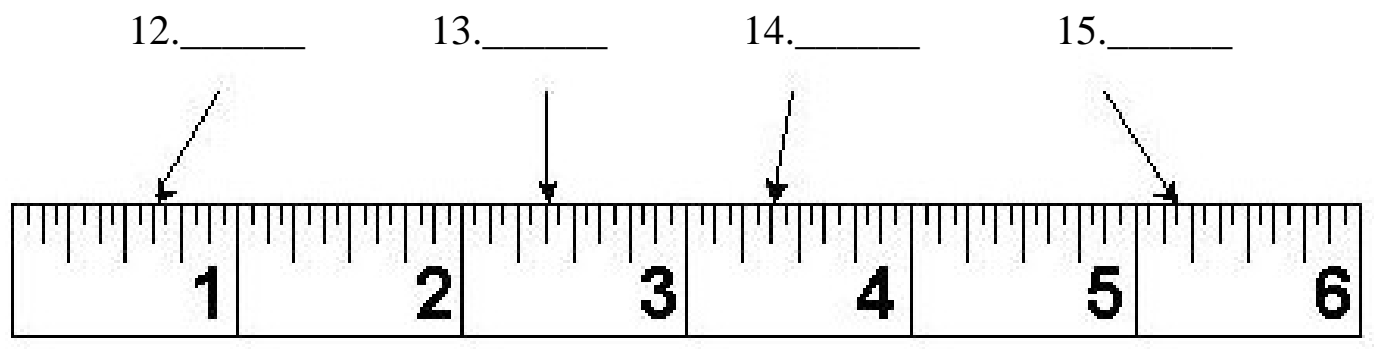




\section{Computer Skills Pre-Test}

\section{Basic Computer Skills Survey}

1. Have you used a computer before?

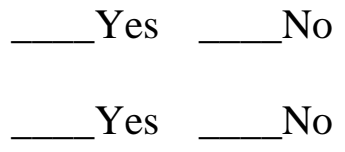

3. How well can you type?

_ Good __ OK Not Good

4. What software programs have you used?

a. Microsoft Word or other word processor?

b. Excel or other spreadsheet program?

c. Outlook or other email program?

d. Internet Explorer or other Internet browser?

e. NEAT, MHEA, or other energy audit software?

$\begin{array}{rr}\text { Yes } & \text { No } \\ \text { Yes } & \text { No } \\ \text { Yes } & \text { No } \\ \text { Yes } & \text { No } \\ \text { Yes } & \text { No }\end{array}$

\section{Windows Basics Test}

Perform the following tasks on the computer.

1. Open three different software programs, resize and position the windows so you can see all three applications on the screen at once.

2. Minimize all three programs and create a new folder on the desktop.

3. Create a word-processing file and save it on the desktop

4. Move this new file into the new folder using drag and drop.

5. Open the folder and confirm you successfully moved the file.

6. Using the Windows Help menus locate instructions for cut and paste and drag and drop. Point to what tutorials come with windows for learning file management. (copy, delete, move, rename, view properties)

\section{File Management Basics Test}

Nearly everything you'll do with computers revolves around creating content in the form of different types of files using different software programs. You'll need to be comfortable with creating, saving, opening, and editing files. Then you'll need to understand storing, organizing, renaming, moving, copying, deleting and backing up your important files. Plan on learning by doing. Mistakes are considered positive learning experiences and are an essential part of using and learning computers. Trouble-shooting gets easier with practice. 
Begin by drafting a personal list of the computer skills you have and the skills you want to learn. Then complete the following tests.

1. Create a new folder on the desktop named "Test Folder \#1" and save a simple word processing document to this folder.

2. Create a folder named "Test Folder \#2" within "Test Folder \#1" and move the word processing file into this new folder.

3. Put a copy of this file into the first folder you created.

4. Rename this file.

5. Create another new folder on the desktop named “Test Folder \#3" and move Test Folder \#2 into this folder.

6. Delete all these folders and files.

\section{Copy and Paste Basics Test}

Perform the following tasks on the computer.

1. Highlight a section of text in a document and copy it to another location.

2. Highlight a section of text in a document and move it to a new location.

3. Highlight an image in a document and copy it to another location. Then, move the image to new location.

\section{Spreadsheet Basics Test}

Circle the letter of the best answer.

1. Spreadsheets:
a. Are large amounts of information
b. Organize text and numbers into columns and rows
c. Are usually graphics

2. Columns are:
a. Labeled with numbers
b. Not labeled
c. Labeled with letters

3. Rows are:
a. Labeled with numbers
b. Not labeled
c. Labeled with letters 
4. What are the intersection of a column and a row?
a. Formulas
b. Entries
c. Cells

5. The column and row label combined at the point of intersection is known as the:
a. Active cell
b. Cell name
c. Formula

6. What are the sets of instructions that produce a value for a cell?
a. Addresses
b. Spreadsheets
c. Formulas

7. What character should start any formula?
a. Plus sign $(+)$
b. Any operator $(+,-, *, /)$
c. Equals sign $(=)$

8. Which formula will produce the total cost of all weatherization measures?

\begin{tabular}{|l|l|r|r|r|r|r|}
\hline & \multicolumn{1}{|c|}{ A } & \multicolumn{1}{c|}{ B } & \multicolumn{1}{c|}{ C } & \multicolumn{1}{c|}{ D } & \multicolumn{1}{c|}{ E } & \multicolumn{1}{c|}{ F } \\
\hline $\mathbf{1}$ & Measure & Hours & Rate & Labor & Materials & Total \\
\hline $\mathbf{2}$ & Air sealing & 4 & $\$ 30$ & $\$ 120$ & $\$ 200$ & $\$ 320$ \\
\hline $\mathbf{3}$ & Attic insulation & 3 & $\$ 30$ & $\$ 90$ & $\$ 324$ & $\$ 414$ \\
\hline $\mathbf{4}$ & Sidewall insulation & 8 & $\$ 30$ & $\$ 240$ & $\$ 312$ & $\$ 552$ \\
\hline $\mathbf{5}$ & Water heater wrap & 0.5 & $\$ 30$ & $\$ 15$ & $\$ 14$ & $\$ 29$ \\
\hline
\end{tabular}
a. $=\operatorname{SUM}(\mathrm{F} 2: \mathrm{F} 5)$
b. $=\mathrm{F} 2+\mathrm{F} 3+\mathrm{F} 4+\mathrm{F} 5$
c. $=\mathrm{SUM}(\mathrm{B} 5: \mathrm{F} 5)$
d. Both $a$ and $b$ 


\section{Appendix C: Glossary}

Air Barrier - The air barrier of a dwelling, also known as the pressure boundary, is the building shell surface that limits airflow between inside and outside. For maximum energy efficiency and comfort, the air barrier and thermal barrier should be continuous and in contact with each other.

ASHRAE - American Society of Heating, Refrigeration, and Air Conditioning Engineers

ASHRAE 62 - ASHRAE 62 is a group of ASHRAE standards for minimum building ventilation requirements. ASHRAE 62.1-2004, entitled Ventilation for Acceptable Indoor Air Quality, cover general topics and requirements for commercial and high-rise residential buildings. ASHRAE 62.2-2004, Ventilation for Acceptable Indoor Air Quality in Low-Rise Residential Buildings, has a self-explanatory title.

Attic Ventilation - Building codes require attic openings to outside to induce airflow that cools the attic in summer and exhausts moisture. There is a growing consensus that unvented attics have energy benefits and that in hot, humid climates attic ventilation brings in more moisture from outside than it purges.

Auditor - An auditor is a weatherization worker that assesses an eligible dwelling for potential weatherization services. Auditors visually inspect the building shell and mechanical systems; conduct diagnostic, health, and safety tests; record the location, condition, and dimensions of walls, ceilings, floors, windows, doors, and mechanical systems; enter data into computerized energy audit or use a priority list to select costeffective measures; and prepare clear and accurate work orders to ensure the most appropriate measures are installed properly.

Balloon-Framed Walls - Balloon-framed walls are built without top or bottom plates. This type of framing often provides an air channel from the basement or crawlspace to the attic that allows outside air to flow through the walls resulting in excessive heat loss/gain.

Band Joist - Band joists are the floor joists that run around the perimeter of the house. There are two types of band joists - header joists that run perpendicular to the floor joists and rim joists that run parallel. A typical weatherization measure involves insulating the header joist spaces between floor joists and along the rim joists.

Base Load - Base loads are energy loads from appliances that are on most of the time and do not vary with changing climate. Base loads include refrigerators, water heaters, and lights. Base loads are often thought to be primarily electric loads, but can be fueled by other energy sources.

Batt Insulation - Batts are fiberglass insulation manufactured in rolls precut to standard widths to fit snugly between framing (joists, rafters, or studs) on 16-inch or 24-inch centers in ceilings, floor, and walls. While often made with a "Kraft" paper facing 
designed to retard vapor transmission, batt insulation is also available without the paper facing (unfaced batts).

Blower Door - A blower door is a device for testing the airtightness of a building. A blower door consists of a calibrated fan for measuring an air flow rate and a pressure sensing device to measure the pressure created by the fan flow. The combination of pressure and flow can be used to estimate the airtightness.

Building Performance Institute (BPI) - BPI is an organization that supports the development of a professional building performance industry through individual and organizational credentialing and a quality assurance program. BPI offers certification of individuals in evaluation, mechanical, envelope, mobile home, and multi-family designations, as well as accreditation of organizations committed to using a quality management system.

Building Science - Building science is the collection of scientific knowledge that focuses on the analysis and control of the physical phenomena affecting buildings. This includes the detailed analysis of building materials and building envelope systems.

Building Tightness Limit - Also known as the minimum ventilation rate, the building tightness limit is the least amount of fresh air that must be drawn through a house (by either natural or mechanical means) to ensure acceptable indoor air quality.

Bypass - A bypass is a hole between conditioned and unconditioned space that allows air leakage through the pressure boundary, or air barrier, of a dwelling.

CAZ - A combustion appliance zone, or CAZ, is any zone containing a combustion appliance.

CO - Carbon monoxide

Combustion Air - Complete combustion of fossil fuels such as natural gas, propane, and fuel oil requires an adequate supply of air. Inadequate combustion air causes incomplete combustion, which generates carbon monoxide.

Combustion Appliance - A combustion appliance is a furnace, boiler, space heater, wood stove, water heater, cook stove, or other device that burns wood or fossil fuel such as natural gas, propane, or fuel oil.

Compact Fluorescent Lamp - A compact fluorescent lamp (CFL) is a type of fluorescent lamp that screws into a regular light bulb socket or plugs into a small lighting fixture. In comparison to incandescent light bulbs, CFLs have a longer rated life and use less electricity.

Competency - Competency means the possession of a minimum level of knowledge and proficiency required to collect appropriate information, make informed decisions, and 
physically takes the needed actions to deliver the high-quality weatherization service in question.

Consumer/Client Education - Consumer or client education includes discussion, instruction, brochures, and pamphlets that explain the weatherization process, the measures installed in the client's house, how to use certain measures (such as programmable thermostats), and low-cost/no-cost ways to save energy and reduce energy costs.

Crew Chief - A crew chief is a weatherization worker that supervises a crew of installers and directs their efforts to weatherize eligible dwellings.

Critical Junction Point - Critical junction points are areas in building construction that typically exhibit air leaks or are inadequately insulated. Critical junction points include the intersection of ceilings and walls, cantilevers, and finished-attic kneewalls.

Cross Training - Training every member of a crew to be able to do every job is known as cross training. While certain crew members may specialize in specific tasks, a crosstrained crew understands how their specialty impacts all others and can adjust to staff turnover.

Delta $\mathbf{Q}$ - Delta $\mathrm{Q}$ is a testing protocol to measure duct leaks to the outside under actual operating conditions.

Demonstrated Ability - A demonstrated ability is the physical performance of a test, procedure, or technique on an actual house, a prop, or in a training lab in the presence of someone qualified to assess the particular competency.

Dense-Packed Cellulose Insulation - Loose cellulose insulation is blown into closed building cavities (usually walls, but also roof/ceiling cavities) to a density of $3 \frac{1}{2}$ pounds per cubic inch to air seal as well as insulate.

DOE - U.S. Department of Energy

Dropped Soffit - A dropped soffit (or simply drop soffit) is built from framing and drywall over kitchen cabinets to give a more finished appearance than just hanging wall cabinets with a foot or so gap between the top of the cabinet and the ceiling. From the attic, a dropped soffit looks like a big hole in the floor and often causes breaks in the attic thermal and air barriers.

Duct Blaster - A Duct Blaster is a calibrated airflow measurement system designed to test and document the air tightness of forced-air duct systems. Duct Blaster is the trade name of the device manufactured by the Energy Conservatory of Minneapolis, Minnesota. Other competing companies such as Infiltec and Retrotec manufacture similar systems. 
EPA - U.S. Environmental Protection Agency

HVAC - Heating, ventilation, and air conditioning

HVAC Installer/Contractor - A HVAC installer/contractor is a crew member or contractor trained and licensed to repair and replace furnaces, boilers, air conditioners, and related equipment.

Hydronic Distribution Pipes - Hydronic distribution pipes deliver hot water or steam from a water heater or boiler to baseboard convectors or radiators located throughout a house.

Inspector - An inspector verifies the proper selection, installation, and effectiveness of weatherization measures installed in eligible dwellings through review of documentation, visual inspection, and performance of diagnostic, health, and safety testing.

Installer - An installer is a crew member or contractor that installs weatherization measures in eligible dwellings.

Knob-and-Tube Wiring - Older homes may have "knob-and-tube" electrical wiring, where two separate wires run through ceramic posts (knobs) attached to the top of ceiling joists or through ceramic tubes inserted into holes drilled in the wall or roof framing. Since this type of wiring was designed to dissipate heat to the attic air, insulating over knob-and-tube wiring can cause dangerous overheating.

Lead-Safe Work Practices - Lead-safe work practices are the use of specific precautions in the conduct of weatherization activities designed to avoid contaminating homes with lead-based paint dust and debris, and to avoid exposing the clients, weatherization workers, and their families to this hazard.

Mastic - Mastic is a material used to seal duct leaks. It is the consistency of drywall joint compound when applied, but dries to a hard, durable finish. To seal duct leaks larger than $1 / 4$ inch, mastic is applied over a specially made fiberglass mesh tape.

Material Safety Data Sheet (MSDS) - A material safety data sheet or MSDS describes the properties of a particular substance (e.g., caulk, mastic, sealant). An important component of workplace safety, it is intended to provide workers and emergency personnel with procedures for handling or working with that substance in a safe manner.

Mechanical Ventilation - Mechanical ventilation is the controlled exhaust of indoor air, intake of fresh outdoor air, or a combination of both through the use of fans, controls, passive air intakes, and sometimes ducts, registers, and air-to-air heat exchangers.

Minimum Ventilation Rate - Also known as the building tightness limit, the minimum ventilation rate is the least amount of fresh air that must be drawn through a house (by either natural or mechanical means) to ensure acceptable indoor air quality. 
Monitor (Administrative) - An administrative monitor is someone employed or contracted by a state to review the administrative and programmatic activities of local weatherization agencies (subgrantees) to ensure compliance with applicable laws and programmatic and financial regulations.

Monitor (Technical) - A technical monitor is someone employed or contracted by a state to review the technical and field activities of local weatherization agencies (subgrantees) to ensure compliance with the enacting federal legislation, federal program regulations, and state technical program standards.

NASCSP - National Association for State Community Services Programs is a national association charged with advocating and enhancing the leadership role of states in preventing and reducing poverty. NASCSP's members are state administrators of the U.S. Department of Health and Human Services' Community Services Block Grant (CSBG) and the U.S. Department of Energy’s Weatherization Assistance Program. NASCSP keeps its members, the federal government, and other interested parties informed about issues related to CSBG and the Weatherization Program through its publications and training.

OSHA - The Occupational Safety and Health Administration's mission is to assure the safety and health of America's workers by setting and enforcing standards; providing training, outreach, and education; establishing partnerships; and encouraging continual improvement in workplace safety and health.

Personal Protective Equipment - Equipment such as respirators, safety goggles, disposable coveralls, and hard hats worn by weatherization workers to protect them from jobsite hazards.

Plenum - A plenum is the initial duct on the supply and return side of an air handler.

Pressure Pan - A pressure pan resembles a cake pan and is used to locate duct leakage with a digital manometer while a blower door is running.

Priority List - A priority list is a list of weatherization measures appropriate for typical housing stock ordered by descending cost effectiveness. DOE-approved energy audit software is used to verify the cost effectiveness of the measures and account for the interaction between measures.

R-Value - R-value is a measure of resistance to heat flow. Insulation with an R-value of $\mathrm{R}-38$ resists heat loss better than $\mathrm{R}-19$ insulation.

Room Pressure Imbalances - Pressure imbalances happen when the conditioned air supplied to a room does not equal the airflow returned to the furnace or air conditioner. In dwellings with forced-air distribution and a central return system, closing bedroom doors can cause the bedrooms to experience a positive pressure and rooms that are open 
to the return grille see a negative pressure. Atmospherically vented combustion appliances can backdraft if they are located in a zone with negative pressure.

Steam Trap - Steam traps are automatic valves used in steam heating systems to remove condensed steam (hot water) from the steam pipes and return it to the boiler.

Temperature-Rise Test - A temperature-rise test is conducted on a furnace by measuring the temperature of air entering the furnace and of the air exiting the furnace. The difference between these two temperatures is known as the temperature rise and is compared to the normal range indicated on the nameplate to verify proper operation of the furnace.

Thermal Barrier - The thermal barrier of a dwelling is the building shell surface that limits heat flow. For maximum energy efficiency and comfort, the air barrier and thermal barrier should be continuous and in contact with each other.

Unvented Combustion Appliance - An unvented combustion appliance vents combustion gases to the living space instead of outside as does a vented appliance.

Weatherization Plus - The U.S. Department of Energy's effort to plan the continued evolution of the Weatherization Program for the next five years through activities designed to expand resources (leveraging and partnerships), share relevant information with the weatherization network, and increase the consistent delivery of high-quality weatherization services nationwide.

Work Order - A work order describes what weatherization measures are to be installed in an eligible dwelling and includes a list of the type and quantity of materials that are required to complete the job.

Working Knowledge - Working knowledge of means to:

- Knowing how a particular topic impacts the weatherization process;

- Having the relevant information committed to memory or being able to locate it in readily available sources; and

- Using the knowledge to make informed decisions and guide weatherization work.

Worst-Case Draft Test - A worst-case draft test is procedure used to verify the ability of a combustion appliance to safely exhaust combustion gases outside even when exhaust fans, pressure imbalances, and the stack effect are fighting its ability to properly draft.

Zone Pressure Diagnostics - Test procedures used with the blower door to locate air leakage are known as zone pressure diagnostics. 


\section{THRHA ADVANCED WEATHERIZATION}

Name:

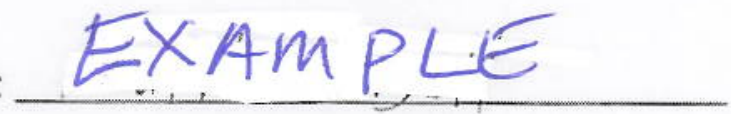

Date: 24 September 2010

1. Infiltration and exfiltration are dominated by which effects:
1.
2. WINB
3. Mechanical ventilation
4. Temperature duLT leakaze Effeut

2. When conducting a house depressurization test, always stand at least l ft from the side of the fan inlet?

3. What would be the proper term to describe the following; the airflow in CFM needed to create a change in building pressure of $50 \mathrm{~Pa}$.

$$
\text { CFMs }
$$

4. Match the following pressures to the correct abbreviation:
1. $10 \mathrm{~Pa}$
$24 \mathrm{~Pa}$
A
A). ELA
B). EqLa

5. Sealing holes above the neutral pressure plane moves the neutral pressure plane dowa

6. When measuring or testing a negative air pressure limitation, what would be the maximum allowable pressure based on the following description: An appliance that takes combustion air and chimney draft dilution from within the building? S pascal

7. When placing the blower door where there are stairwells or other major obstructions to airflow, keep these obstruction/objects $4-6 \mathrm{ft}$ away from the fan inlet.

8. Given the following; a $32^{\prime} \times 48^{\prime} 2$ story house, 8 foot ceilings, 12 inch floor joists, $6 / 12$ cathedral ceiling, and a 2 ' 8 " insulated concrete form foundation without foundation vents.

1). what is the conditioned volume of this building? $37,888 \mathrm{cubicft}$

2). what is the surface area of this building? $6,81654.6384$

9. When measuring duct leakage, if the dominant leakage is found in the supply ducts, the house will be

10. Define Pascal:
A). a measure of airflow
B). a measure of air temperature
C) a measure of air pressure
D). a measure of air resistance 
E). none of the above

11. A blower door measures:

A). size of openings in a building B). pressure differences

C). air flow

E). both $b$ \& $c$

D). air infiltration

(G). all of the above

F). both a \& d

12. When doing a "One Point" blower door test and to get a quick visual snapshot of the air leaks encountered we can use the Approximate Leakage Area (ALA) method. Given a house with a 5100 CFM50, and utilizing the ALA method, what could this tell us?

$$
510 \% 10=510=\text { ALA } 510^{59} \text { incke of leakage. }
$$

13. When preparing a building for an airtightness test, what is done to the following building components prior to testing:
A). fireplace with damper-
B). wood stove with ashes-
close
C). HRV; outside air supply/exhaust- 105 to
D). floor drains, plumbing traps- pour water in
E). boiler barometric damper- Lave alone
F). boiler combustion air ducts- leave alone

14. When performing a blower door test in a middle unit in a townhouse style dwelling unit what two practices could be utilized to equalize pressures:
1)
2)

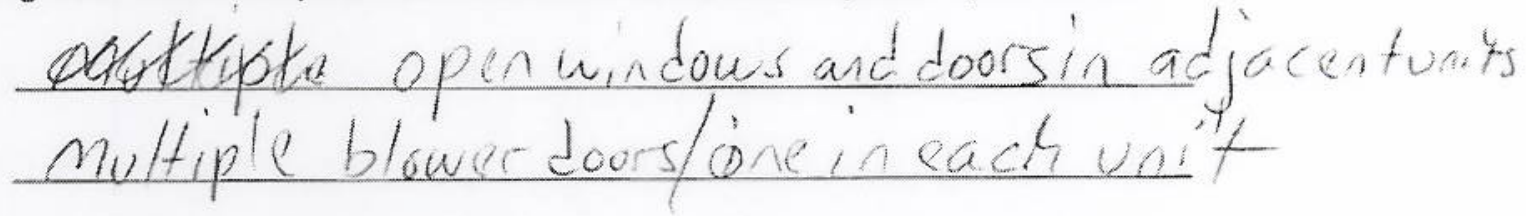

15. What two variables determine airflow across an imperfect air barrier?

b) airflow and pressure

c) leakage area and pressure

$75 \mathrm{cFm}$

d) leakage area and resistance

e) Pascal and CFM

f) Pressure differential and the air barrier surface area

16. 1 Story on crawlspace, Well shielded, Flat ceiling 3 Bedrooms, 5 Occupants, CFM50 1704

Footprint: $28^{\prime} \times 44^{\prime}$

Wall Height: 8'

Heated Floor Area:

Heated Volume:

Surface Area:

Person- BTL CFM50:

Bedroom- BTL CFM50:

Volume- BTL CFM50:

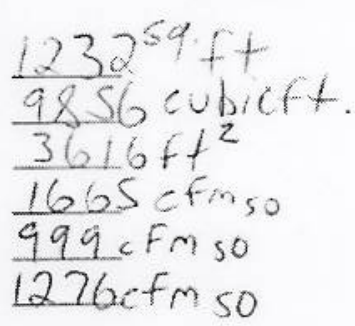

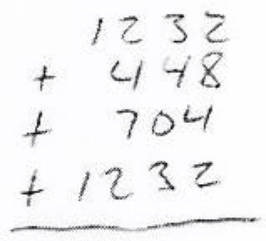




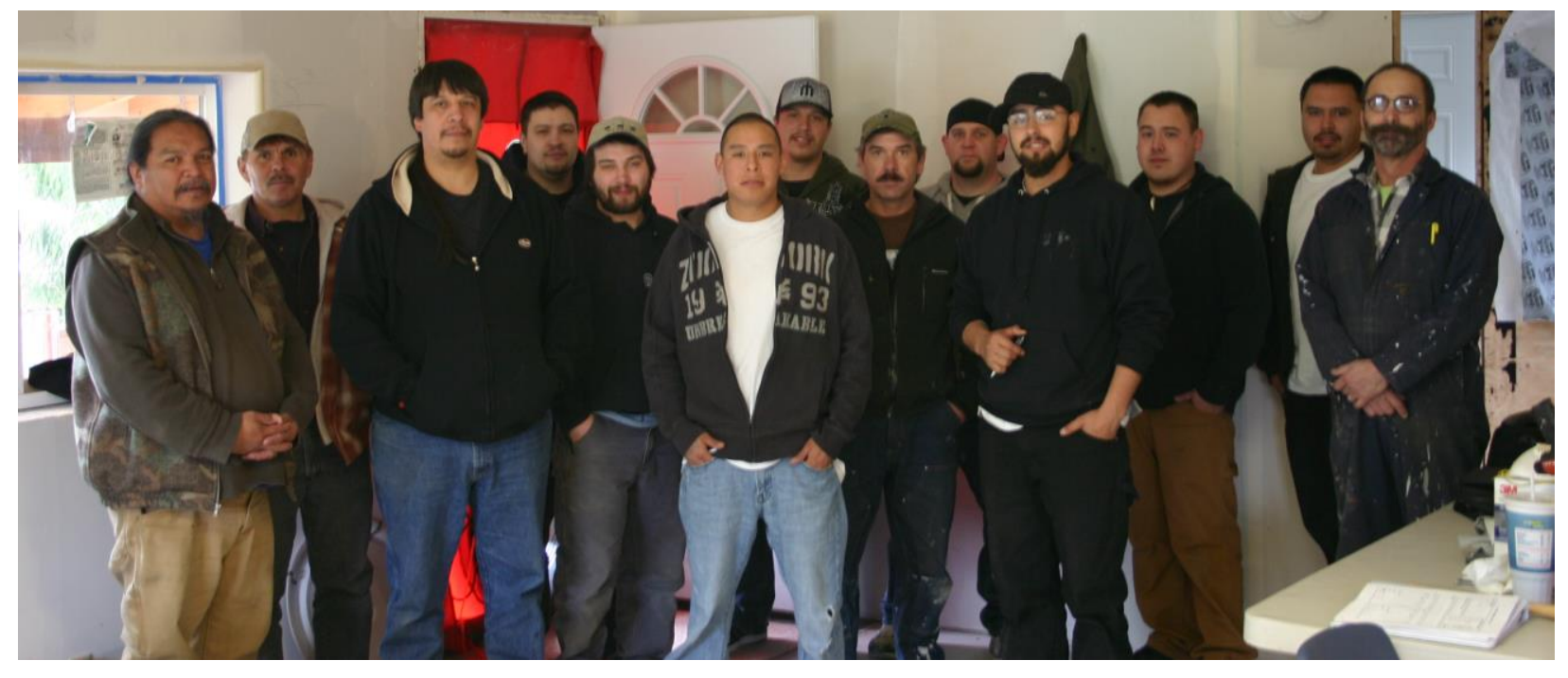

Typically each training course had 8-12 participants. Each course concluded with a graduation event whereby Traditional Tlingit elders (Raven and Eagle) spoke and presented graduation certificates. 


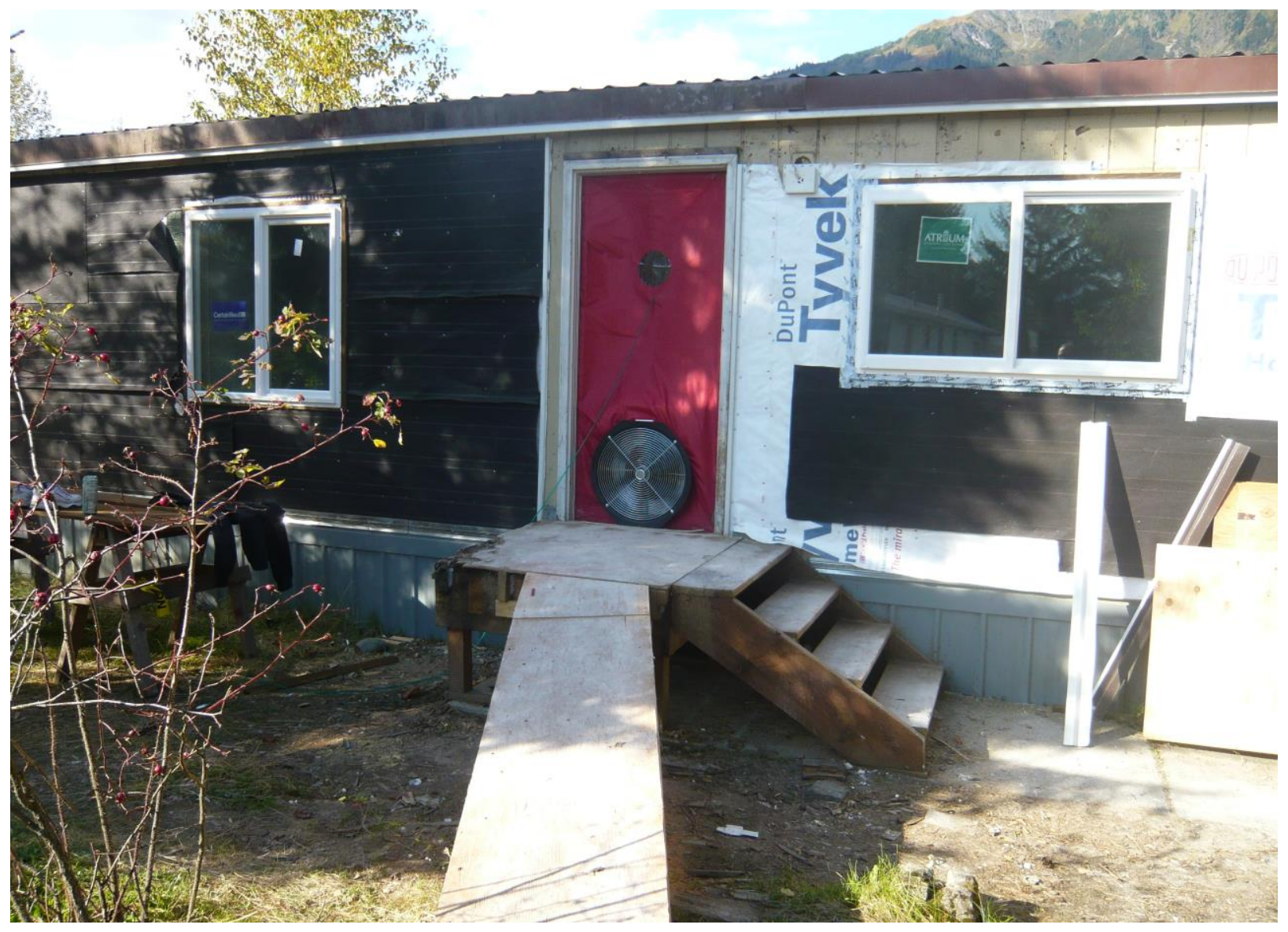

Example of Blower Door for instructional hands on diagnostics testing and training. 


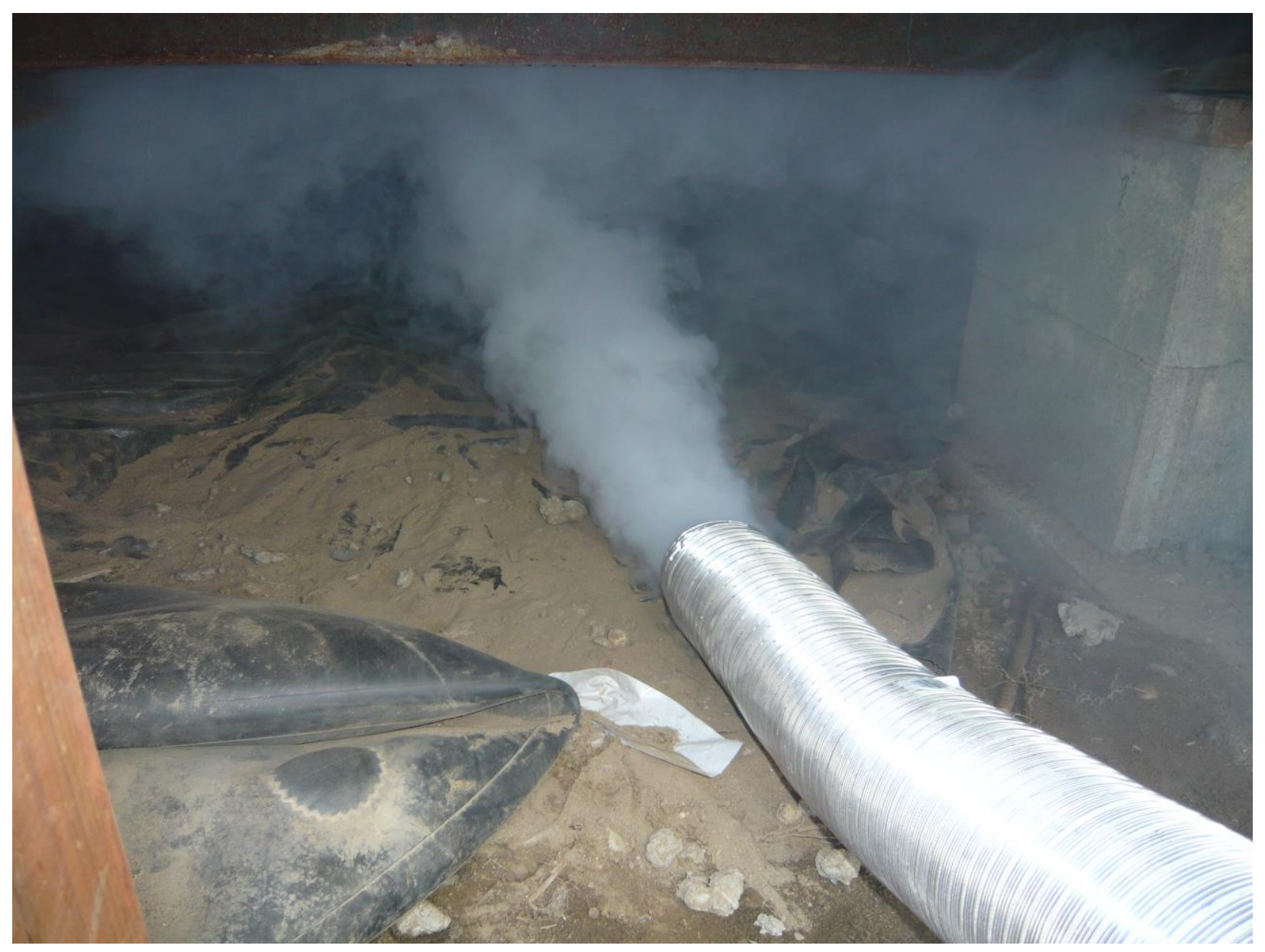

Diagnostic Training at the Training Center. 


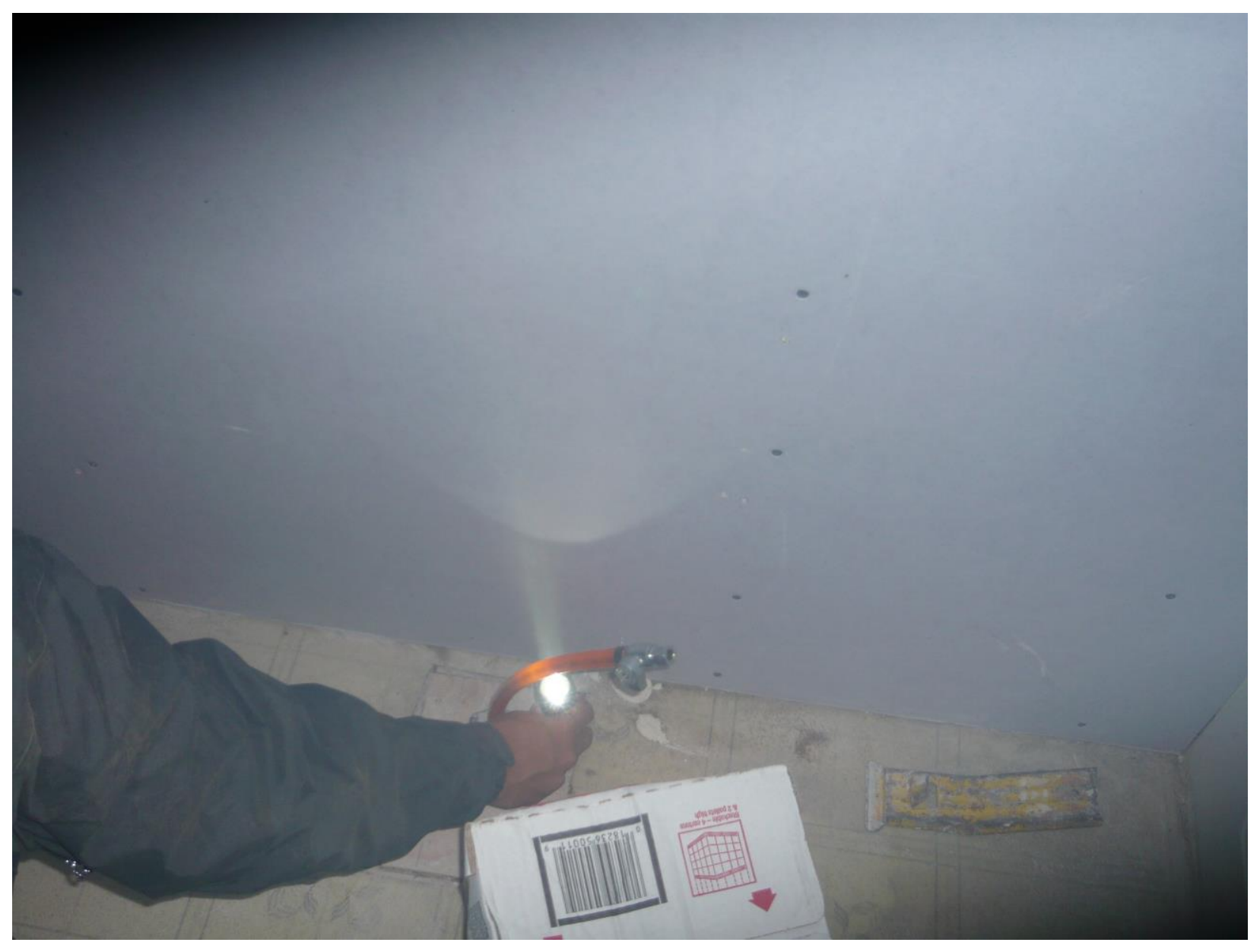




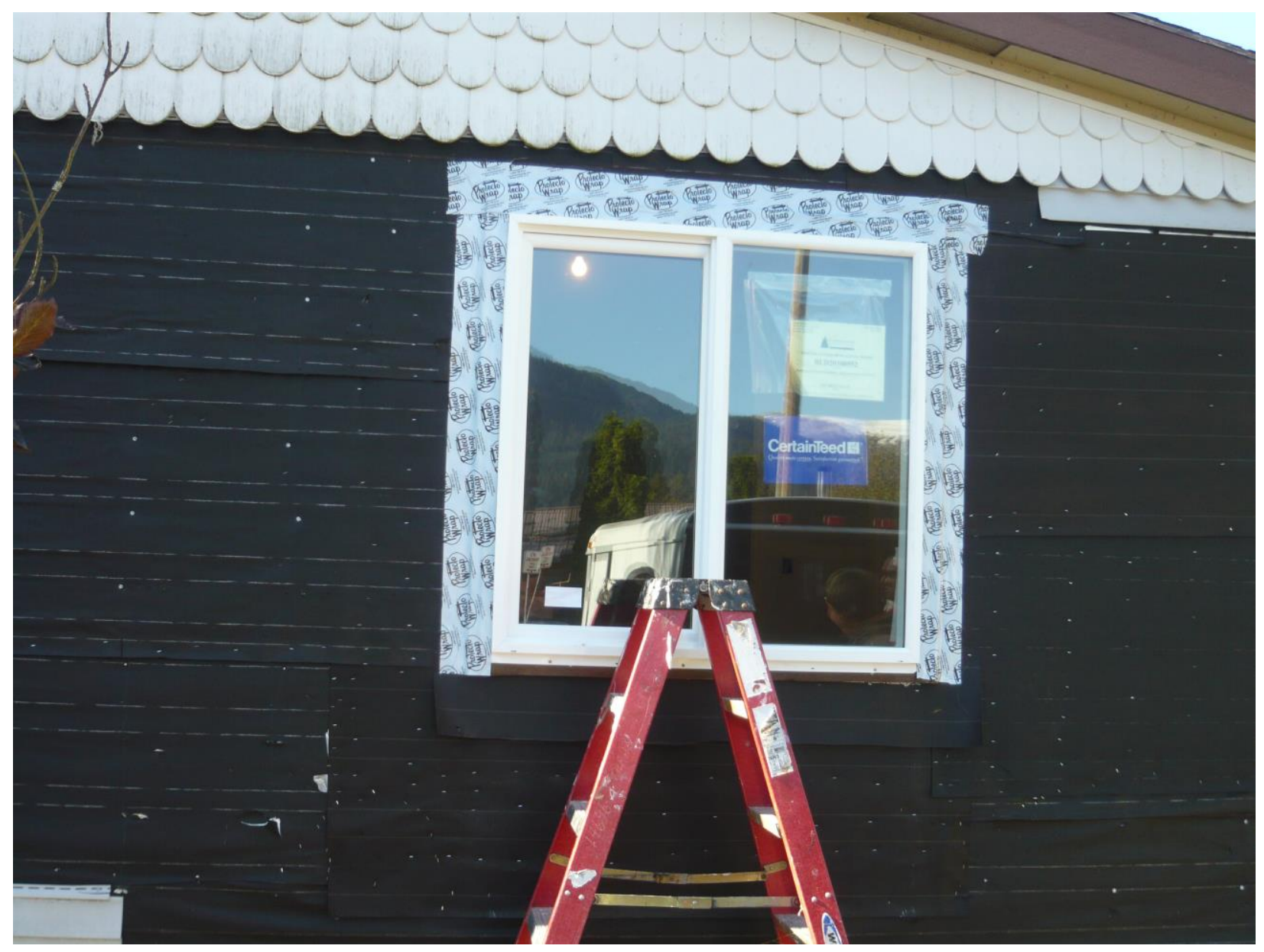

Window installation training. 


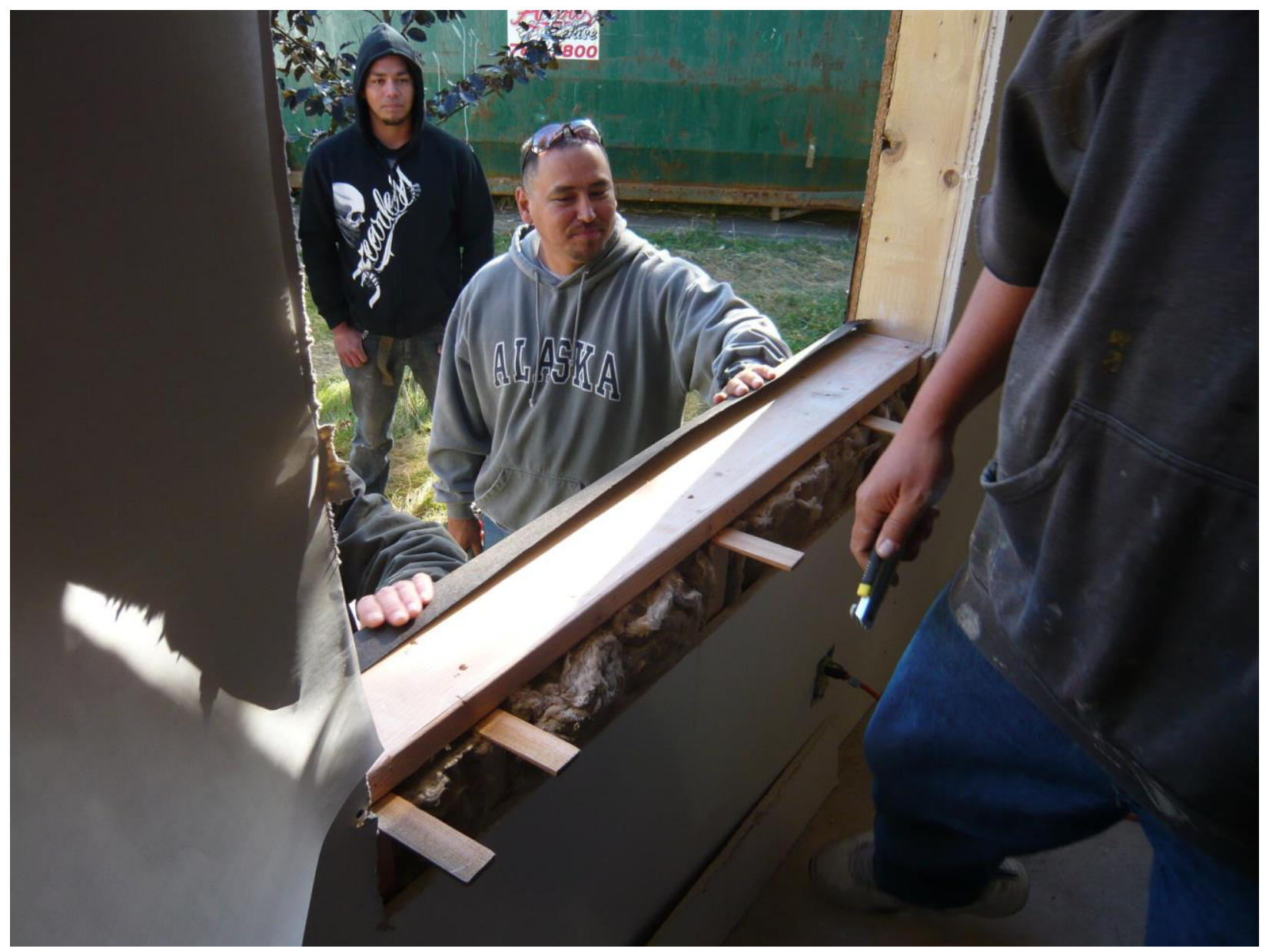

Window and Door installation training. 